UR Wild life R- -

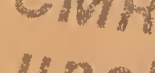

AUM \\ 39.95 predict good huntin
}

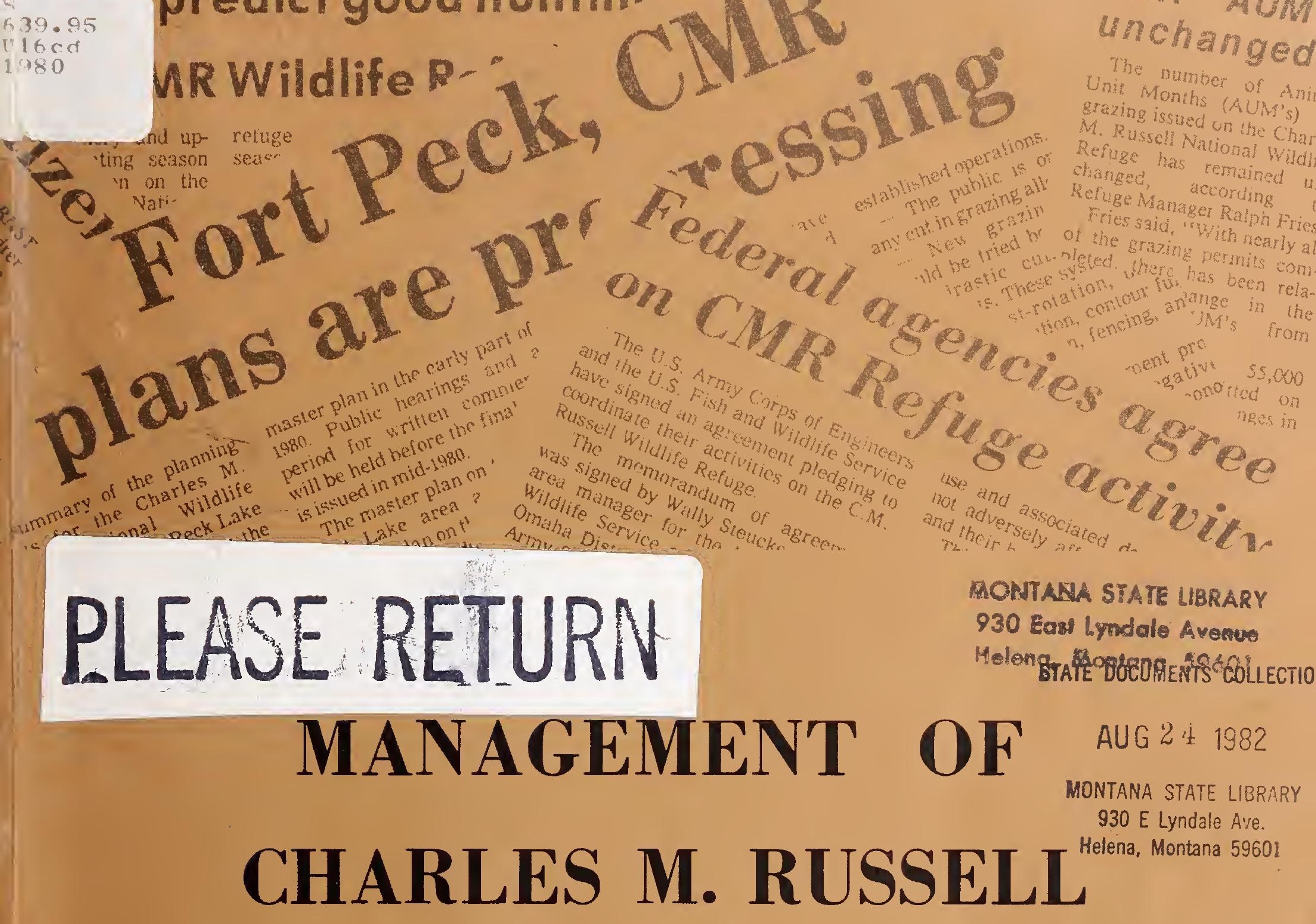

\section{NATIONAL WILDLIFE REFUGE}

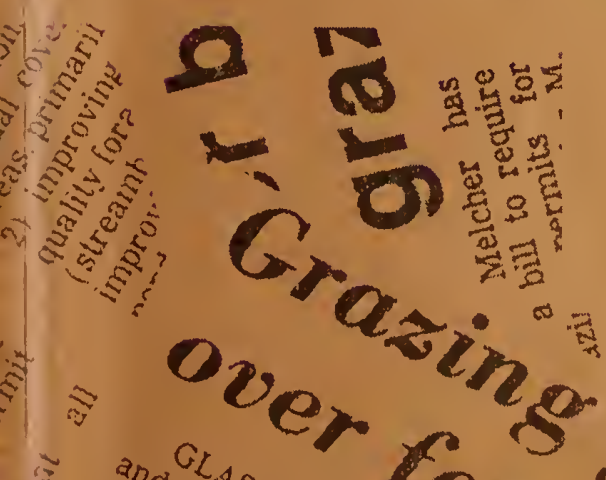

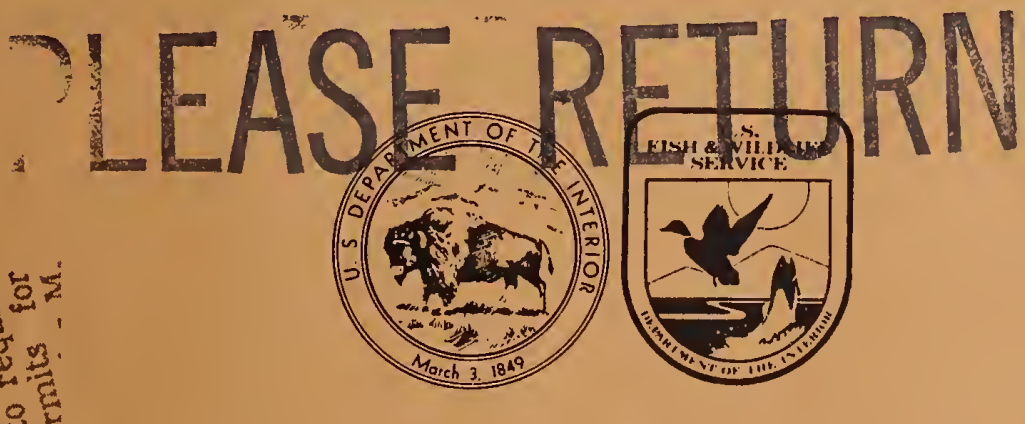

DRAFT

ang

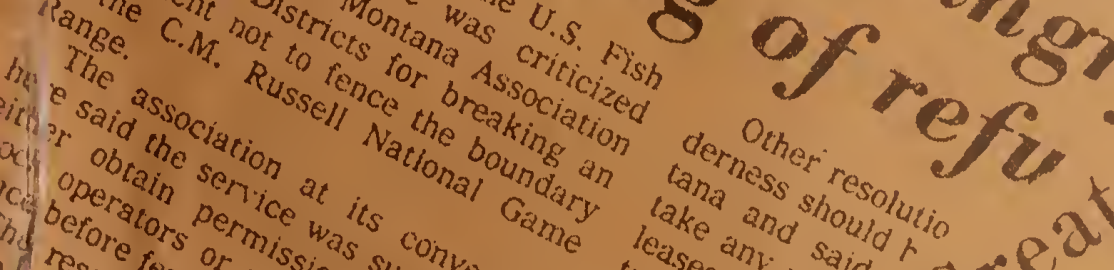

ENVIRONMENTAL IMPACT STATEMENT

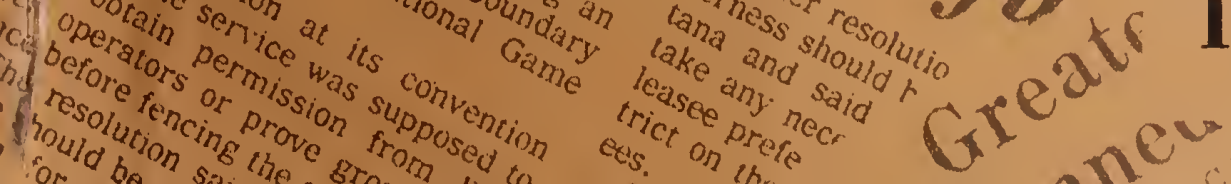


tue

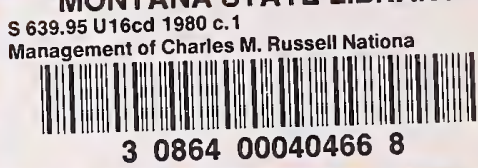




\section{United States Department of the Interior \\ FISH AND WILDLIFE SERVICE \\ MAILING ADDRESS: \\ Post Office Box 25486 \\ Denver Federal Center \\ Denver, Colorado 80225 \\ STREET LOCATION: \\ 134 Union Blud. \\ Lakewood, Colorado 80228}

RW

803.6

August 1980

Dear Reader:

Enclosed for your review and comment is the draft environmental impact statement on Management of the Charles M. Russell National Wildlife Refuge in Montana.

The proposed action is an improved management program for the 1,094,301-acre refuge. Four alternatives were considered: (1) continuation of the present management program (no àction), (2) intensive wildlife management, (3) multiple use, and (4) elimination of livestock.

Additional copies of the draft EIS have been made available to libraries in the six county area of Montana encompassing the refuge.

Please keep this copy of the draft, as only an abbreviated final will be printed. It will contain the statement summary, a history of consultation and coordination including comments received on the draft and an addendum which will contain pages on which changes were made in the draft. This approach will result in substantial cost and energy savings.

Public hearings will be scheduled in Washington, D.C., Lewistown, Glasgow and Missoula, Montana.

Information on the public hearings will be forthcoming.

In order to be considered in preparation of the final EIS and in the agency decision on the proposed management plan, written comments must be received no later than November 17, 1980. Comments should be sent to:

Erwin W. Steucke, Area Manager

Fish and Wildlife Service

Federal Building, Room 3085

316 North 26th Street

Billings, Montana 59101

Testimony received through written comments or at the public meetings will be considered equally during preparation of the final environmental statement. No decisions on the proposed grazing management program will be made until the final environmental statement is completed.

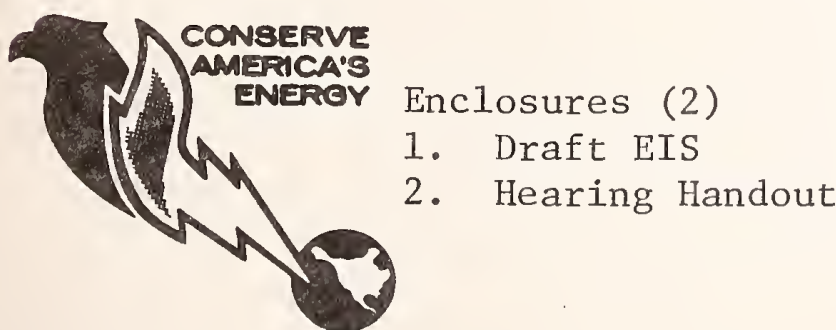

Sincerely yours,

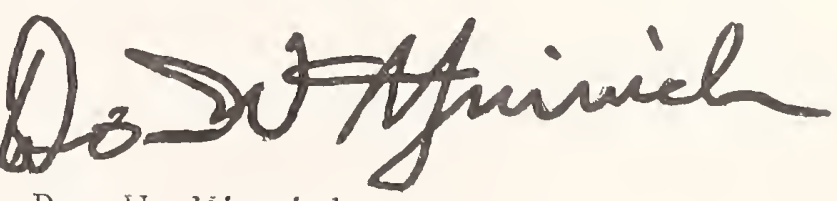

Don W. Minnich

Regional Director 
Digitized by the Internet Archive in 2016 
Management of the Charles M. Russell National Wildlife Refuge has suffered from a lack of comprehensive planning and conflicting jurisdiction by three agencies: Army Corps of Engineers, Fish and Wildife Service and Bureau of Land Management.

Passage of Public Law 94-223 in 1976 solved part of this management problem but the conflicting legislation and mandates between the Corps of Engineers and the Fish and Wildlife Service remain. A memorandum of agreement has been signed by both agencies and is currently being used to facilitate management.

This Environmental Impact Statement presents various options to solve some of the refuge resource problems. The alternative chosen after public review and comment will form the basis for the Charles $\mathrm{M}$. Russell National Wildlife Refuge management plan.

Because habitat is recognized as the key to wildlife abundance, this document emphasizes habitat quality and quantity rather than wild animal populations or densities. Where possible the habitat's capability to support numbers of animals per unit area have been used. Establishment of high quality wildlife habitat will provide adequate populations of wildife species within constraints imposed by drought, severe winters, disease and other variables which are largely uncontrollable.

This Environmental Impact Statement follows the Council of Environmental Quality guidelines for National Environmental Policy Act documents as amended July 30, 1979. Appendices, glossary and an index are in the back of the publication. A large, fold-out map is provided inside the back cover for easy reference. 

CONTENTS

Foreword i

Tables iii

Figures v v

Appendices vi vi visi

Summary viii

I. PURPOSE AND NEED FOR ACTION 1

II. ALTERNATIVES 3

Alternative A (No Action) 7

Alternative B (Proposed Action) 9

Alternative C (Intensive Wildlife Management) 18

Alternative D (Multiple Use) 21

Alternative E (No Grazing) 24

Comparison of Alternatives 26

III. AFFECTED ENVIRONMENT 31

IV. ENVIRONMENTAL CONSEQUENCES 61

Alternative A (No Action) 62

Alternative B (Proposed Action) 70

Alternative C (Intensive Wildlife Management) 81

Alternative D (Multiple Use) 89

Alternative E (No Grazing) 97

$\begin{array}{lll}\text { V. LIST OF PREPARERS AND REFERENCES } & 104\end{array}$

$\begin{array}{ll}\text { VI. CONSULTATION AND COORDINATION } & 124\end{array}$

$\begin{array}{lr}\text { VII. APPENDICES } & 129\end{array}$

$\begin{array}{ll}\text { VIII. GLOSSARY } & 210\end{array}$

$\begin{array}{ll} & 214\end{array}$

$\begin{array}{ll}\text { REFERENCE MAP } & 219\end{array}$ 
1. Summary comparison of effects of implementing various management alternatives on Charles $M$. Russell National Wildlife Refuge, Montana.

2. Comparison of regional income and employment from recreation for five management alternatives for Charles M. Russe11 National Wildlife Refuge, Montana.

3. Comparison of regional effects from grazing for five management alternatives for Charles M. Russe11 National Wildife Refuge, Montana.

4. Land and water acreages within the Charles M. Russell National Wildlife Refuge, Montana.

5. Major documents affecting the Charles M. Russe11 National Wildlife Refuge, Montana.

6. Groundwater sources on Charles M. Russell National Wildlife Refuge, Montana.

7. Competing recreation resources on and near the Charles M. Russell National Wildlife Refuge, Montana.

8. Estimates of current visitation on Charles M. Russell National Wildlife Refuge, Montana.

9. Farm income data for a six-county region at Charles M. Russell National Wildlife Refuge, Montana.

10. Comparative 1974 per capita income for a six-county region at Charles M. Russell National Wildlife Refuge, Montana.

11. Demographic data for counties contiguous to Charles M. Russell National Wildlife Refuge, Montana.

12. Noneconomic effects, No Action alternative, Charles M. Russell National Wildlife Refuge, Montana.

13. Noneconomic effects, Proposed Action alternative, Charles M. Russe11 National Wildlife Refuge, Montana.

14. Noneconomic effects, Intensive Wildlife Management alternative, Charles M. Russell National Wildlife Refuge, Montana. 


\section{TABLES (Cont'd.)}

15. Noneconomic effects, Multiple Use alternative, Charles M. Russell National Wildlife Refuge, Montana.

16. Noneconomic effects, No Grazing alternative, Charles M. Russell National Wildlife Refuge, Montana.

17. Agencies and organizations which received draft copies of the Management of Charles M. Russell National Wildlife Refuge, Montana Environmental Impact Statement for review. 


\section{FIGURES}

1. Recreation proposals, Charles M. Russell National Wildlife Refuge, Montana.

2. Vegetation types, Charles M. Russell National Wildlife Refuge, Montana.

3. Mule deer and white-tailed deer habitat, Charles M. Russel1 National Wild1ife Refuge, Montana.

4. E1k and sharp-tailed grouse habitat, Charles M.

Russell National Wildlife Refuge, Montana.

5. Pronghorn and sage grouse habitat, Charles M. Russe11 National Wildlife Refuge, Montana.

6. Bighorn sheep habitat, Charles M. Russell National Wildlife Refuge, Montana.

7. Prairie dog towns, Charles M. Russe11 National Wildlife Refuge, Montana.

8. Existing recreation resources, Charles M. Russe11 National Wildlife Refuge, Montana.

9. Grazing allotments, Charles M. Russel1 National Wildlife Refuge, Montana.

10. Reference Map, Charles M. Russe11 National Wildlife Refuge, Montana. 


\section{APPENDICES}

1. Section 7 evaluation, Charles M. Russell National Wildlife Refuge, Montana.

2. Habitat evaluation procedures and values on Charles M. Russell National Wildlife Refuge, Montana.

3. Memorandum of agreement between District Engineer, Omaha District, Corps of Engineers and Area Manager, Billings Area Office, Fish and Wildlife Service for the Charles M. Russell National Wildlife Refuge and Fort Peck Lake Project, Montana.

4. Executive Order 7509 establishing the Fort Peck Game Range, Montana.

5. Federal stocking levels in AUMs under each management alternative (livestock) for the Charles M. Russell National Wildlife Refuge, Montana.

6. Public Law 94-223 94th Congress, H. R. 5512 February 27, 1976.

7. Soils limitations and capability classes, Charles M. Russell National Wildlife Refuge, Montana.

8. Range survey methodology and productivity, Charles M. Russell National Wildlife Refuge, Montana.

9. Range condition class by breakdown by livestock operator and allotment on the Charles M. Russell National Wildlife Refuge, Montana.

10. Summary of grazing permittee operations and impacts of implementing various alternatives on the Charles M. Russell National Wildlife Refuge, Montana.

11. Income in the six-county region at Charles M. Russell National Wildlife Refuge, Montana, 1970 and 1975 (\$000's).

12. Number of persons 14 years or older employed in the six-county region at Charles M. Russell National Wildlife Refuge, Montana, 1960 and 1970.

13. Economic and social consequences methodology, Charles M. Russell National Wildlife Refuge, Montana.

14. Summary comparison of important wildlife habitat conditions for the present situation and five management alternatives on the Charles M. Russell National Wildlife Refuge, Montana. 


\section{APPENDICES (Cont'd.)}

15. Methodology employed in calculation of AUMs on Charles M. Russell National Wildlife Refuge, Montana.

16. Literature review for Charles M. Russell National Wildlife Refuge, Montana, range survey and wildlifelivestock interrelationships.

17. Methodology for estimating visitor use on the Charles M. Russell National Wildlife Refuge, Montana. 
This Environmental Impact Statement (EIS) is prepared in specific response to litigation filed in US District Court for the District of Columbia, entitled Natural Resources Defense Council, Inc. et al. versus Rogers C. B. Morton et a1. (June 1975). The EIS presents five management alternatives to solve some of the resource problems on Charles M. Russell National Wildlife Refuge (CMR), located in northeastern Montana.

Nearly 1.1 million acres comprise CMR of which about 249,000 acres are inundated by Fort Peck Reservoir. The Missouri River flows through the refuge and part of it is administered by the Bureau of Land Management as the nationally designated Upper Missouri National Wild and Scenic River. Besides the grazing activity authorized by the Executive Order establishing CMR, three state parks managed by the Montana Department of Fish, Wildlife and Parks and several recreation areas administered by the Army Corps of Engineers (COE) are located on the refuge, making this an atypical refuge compared to other units of the National Wildlife Refuge System.

Although varying quantities of oil, gas and coal are known to occur beneath the rugged landscape, these and other energy resources have a low to moderate potential for development. However, development of these resources outside the refuge and in the surrounding region could increase significantly in the future and would have far-reaching impacts on the refuge.

Soils on the refuge fall into four major orders: Mollisols, which are highly productive prairie soils and are quite limited; Aridisols, which possess potential for agricultural use; Entisols, which typically are found in the "breaks" portion of the refuge and have a very unstable surface and Vertisols, which are commonly associated with fine textured Bearpaw shales found on strongly sloping sedimentary uplands. Soils and weathered bedrock on the refuge are moderately to highly expansive, tending to swell when wetted and heave when excavated which limits the types of development they can support.

Five major vegetative types exist on the refuge, the largest being the sagebrush-greasewood-grassland type that comprises more than 60 percent of the area. About 35 percent of the area is associated with the ponderosa pine-juniper type. Grassland, riparian and cultivated land types occupy the balance of the area. Although the riparian community was extensive before being inundated by Fort Peck Reservoir, it now occupies only 0.7 percent of the area and provides one of the most important and productive wildlife habitat types.

Warm summers and cold winters create a harsh environment. From the uplands to the flood plains, the great variation in topography and vegetation creates a diversity of wildlife habitat. Plains grizzly bears, American bison, Audubon bighorn sheep and wolves once roamed the refuge, but are no longer present. Even before their time, the area supported a rich assemblage of plant and animal life, as evidenced by significant paleontological discoveries in the Hell Creek and Fort Union formations. 
Today the primary species are mule deer, white-tailed deer, pronghorns, Rocky Mountain elk, sharp-tailed and sage grouse and black-tailed prairie dogs. No threatened species of animals are known to occur on the refuge. Endangered wildlife species include peregrine falcons, bald eagles and possibly black-footed ferrets. The refuge may be within the geographical distribution of Rorippa calycina, a species of watercress which may be classified as a threatened or endangered plant species in Montana.

Wildlife habitat on the refuge is only in fair condition. Present deficiencies in habitat include lack of residual cover (grasses and forbs) on upland sites, around ponds and in hardwood draws, poor quality and small quantity of deciduous shrubs and trees in hardwood draws and along minor stream courses, poor quality sagebrush stands and insufficient timber density in some areas. There is potential to improve most of the habitat on CMR.

In terms of climax range vegetation, the refuge is predominantly in good condition. Where deteriorated conditions are present, poor livestock distribution is the most common problem, causing about seven percent of the grazed portions of the refuge to be in fair range condition. Portions of the refuge in poor range condition are generally associated with prairie dog towns or flood plains.

The refuge has relatively few developed recreation areas. Most of these are COE areas located near Fort Peck Townsite and the Big Dry Arm segment of the reservoir. Private cabins are located on federal land at four locations. Including visitation at $\mathrm{COE}$ and state facilities, an estimated 357,000 visitor days of use occurred on the refuge in 1978. The most popular activities were viewing scenery and exhibits, picnicking, fishing, powerboating and camping. Most of this use occurred near developed recreation areas on the east side of the refuge.

Numerous prehistoric campsites, tipi rings, stone markers, bison kill sites, homesteads, pioneer graves and townsites are scattered throughout the area. There is one designated national historic site, two national natural landmarks, four research natural areas, one designated wilderness area, 15 proposed wilderness areas and the Upper Missouri National Wild and Scenic River.

Grazing and haying activities on the refuge, although limited, contribute to the economy. Expenditures by recreationists generate additional income, as does hydropower production from Fort Peck Dam and Reservoir. The area around the refuge has been characterized by relatively slow economic growth with an economy based on the production of grain and livestock.

In 1979 there were 67 grazing allotments located partially or totally on the refuge, consisting of 87 individuals, companies or associations grazing about 60,000 animal-unit months (AUMs). Based on a grazing fee of $\$ 1.89 / \mathrm{AUM}$, this activity contributes nearly $\$ 107,000$ to the US Treasury. Approximately 800 acres of land were farmed on the refuge by eight cooperators. Income derived from this source was estimated to be less than $\$ 10,000$.

Summaries of five alternatives considered in this document and their probable impacts are: 
Management would continue unchanged. Animal damage control would occur to solve specific problems. Livestock numbers would not change. Major management actions would include surveys, issuing grazing 1icenses, some cooperative farming and wildfire control. There would be no significant improvement in range conditions or wildlife habitat. Recreational developments would remain essentially unchanged.

\section{PROPOSED ACTION ALTERNATIVE}

Black-footed ferrets, peregrine falcons, bighorn sheep and swift fox would be reintroduced as they become available. Wildlife habitat conditions would be substantially enhanced by 2000 with most grazing reductions and other major actions implemented by 1985 and the remainder by 2000 . Wildlife habitat management objectives would be met or exceeded refuge-wide by 2000. Significant management actions would include reduction in livestock grazing as well as changing existing livestock seasons of use and modifying existing grazing systems to benefit wildlife. Some soil ripping, shrub planting and construction of exclosures would occur. Most wildfires would be suppressed and some prescribed burning would occur on the west half of the refuge and in Garfield County. Some boundary fences and a few interior fences would be constructed. Three new reservoirs would be built plus one water pipeline and several troughs. Wildlife habitat would be evaluated periodically to ensure that wildlife objectives were being met; necessary corrections in management would be made. Farming along the Missouri River would be phased out but some lure crop farming would be implemented to decrease elk depredation on private lands. Animal damage control would be similar to the No Action alternative.

Federa1 livestock AUMs would eventually be reduced 33 percent below levels presently authorized to achieve a light grazing level determined to be consistent with wildlife objectives. Some inholdings would be acquired and ownership of all lands within CMR would be ascertained.

There would be more opportunities for wildlife recreation due to improvement of habitat and expected increases in wildlife populations. Present high and low density recreation areas would be retained and expanded as needs dictate. A new boat access site would be established at Fourchette Bay. Private cabin sites would remain as they are. Interpretive programs would be emphasized and access to recreational areas and facilities would be improved.

\section{INTENSIVE WILDLIFE MANAGEMENT ALTERNATIVE}

Changes in State Land Board (SLB) and FWS policy would have to occur to fully implement this alternative. A substantial budget increase would be necessary and COE-FWS legislative conflicts would have to be resolved in favor of FWS.

Endangered and unique species introductions would be as stated in 
the Proposed Action alternative with the addition of bison. About 2000 acres would be farmed in plots of varying sizes to increase wildlife food supplies and habitat diversity. Waterfowl ponds would be developed at UL Bend. Spawning habitat for fish would be developed on the reservoir. Wildlife habitats would be enhanced to maximum potential for most species in a minimum time span. Most actions to achieve desired habitat levels would be implemented by 1985 and the remainder by the year 2000; however, the time required for maturation of certain vegetative communities would take 50 or more years. Burning, farming, soil ripping, shrub and conifer planting and exclosure fencing would be considerably more extensive than the Proposed Action. Periodic habitat evaluation would occur and most wildfires on CMR would be suppressed as stated in the Proposed Action. Some prescribed burning would occur in Garfield County and on the west half of the refuge. All inholdings would be acquired. Predator control to protect livestock and prairie dog control would be the same as the No Action alternative. Coyote and small mammal control to benefit other wildlife species would be minimal. The naturalness management concept would be eliminated in favor of developments which would provide maximum benefits to wildlife.

Livestock grazing would be employed as a tool to achieve or maintain desired wildlife habitat. Livestock AUMs would be reduced to about 27,000-30,000 federal AUMs as a result of this alternative.

Range improvements would be limited to approximately 400 miles of boundary fence to regulate livestock plus ripping of all suitable panspots and dense clay range sites outside wilderness areas.

Recreation would be oriented toward wildlife activities. Private cabins would be eliminated and the areas returned to wildlife habitat. More primitive fishing access sites would be provided and replace some existing high and low density recreation areas. Nature trails would be established at several locations.

\section{MULTIPLE USE ALTERNATIVE}

This alternative would require Congressional action to implement. It would emphasize all resources instead of just wildlife. Wildlife values would be equal to livestock as would recreation. This alternative would provide only slight improvements in habitat quality and wildlife objectives would not be met by the year 2000. About 41,000 acres would be improved for wildlife habitat by prescribed burning, soil ripping, shrub planting and farming. Ten miles of exclosure fence would be constructed. Most wildfires would be controlled as soon as possible.

Animal damage control for livestock losses would be conducted under the same regulations as adjacent land. Animal damage control for wildlife other than coyotes would be minimal. Waterfowl production areas would be expanded at UL Bend. Endangered and unique species introductions would be more limited than the Proposed Action alternative.

Livestock would receive approximately one-half the allocated forage. There would be some boundary and interior fence construction. Seventy-seven reservoirs, 2 springs and 13 water troughs would be constructed and deferred or rest-rotation grazing systems would be imple- 
mented on 12 allotments.

Recreational use and development would be greater than with the other alternatives. As needs dictate, high and low density recreation areas would be expanded, a perimeter shoreline scenic road in the vicinity of Fort Peck would be constructed and a major backcountry trail extending the length of the refuge would be designated. Private cabins would remain as they are.

\section{NO GRAZING ALTERNATIVE}

Changes in SLB policy would have to occur before state inholdings could be acquired. All private and state inholdings would have to be acquired before elimination of livestock grazing could occur since most of these areas are unfenced and stocked by the operators at carrying capacity levels. Habitat improvements in residual cover and quantity of forbs would be maximized. Increased shrub quality in hardwood draws would be significant. About 28,500 acres of habitat would be improved by farming, prescribed burning, soil ripping and shrub and conifer planting. Six miles of exclosure fence would be constructed. Wildfire control would be similar to the Proposed Action.

Animal damage control for wildlife and livestock would be the same as the No Action alternative. Endangered and unique species introductions would be similar to the Proposed Action alternative.

A11 livestock grazing would be eliminated by the year 2000. The entire refuge boundary would be fenced where possible.

Recreational development and use would be about the same as the Proposed Action alternative. 

Many wildlife-livestock problems at the Charles M. Russell National Wildlife Refuge (CMR) have resulted from conflicting management and legislation during 40 years of joint administration by the Fish and Wildlife Service (FWS), Bureau of Land Management (BLM) and Corps of Engineers (COE). These agencies embrace differing management responsibilities, goals and philosophies and because of numerous federal laws applicable to CMR, ultimate management authority is unclear. In addition, numerous private and state inholdings complicate management.

When the Fort Peck Game Range (now CMR) was established in 1936, BLM was assigned livestock management and all forage above the needs of wildlife was to be available for livestock grazing. FWS was assigned wildlife management responsibility simultaneously with BLM's responsibility for livestock grazing. Resulting multiple use management did not realize the wildlife potential of CMR. In 1976 grazing responsibilities were transferred to FWS to better realize wildlife potentials. The change shifted grazing management from the Taylor Grazing Act to the Refuge Administration Act.

FWS changes in grazing practices have resulted in distrust and uncertainty of CMR goals by the livestock industry and federal and state agencies. Misunderstanding arises from refuge management, with its dominant purpose for wildlife as opposed to adjacent BLM lands, where multiple use allows more livestock grazing.

Recent challenges at CMR are management of archeological and historical sites, reintroduction of endangered or threatened species, a growing regional and national sentiment by environmental groups for reduction or elimination of livestock grazing versus a local sentiment for more grazing, conflicts regarding consumptive versus nonconsumptive use of wildlife, fencing of the boundary, management of CMR as an isolated wildlife oasis versus management as part of a total ecosystem, local recreation demands that may not be compatible with CMR goals and integration of wildife, recreation and other natural values.

FWS believes that the key to meeting its management objectives on CMR is to evaluate the current status of the resource and devise a master plan, taking into consideration all interests. The planning process has included resource inventories, opportunities for resource development, conflict analyses and a scoping process whereby the public had opportunities to identify significant issues.

The scoping process involved people with diverse backgrounds and interests in many natural resource areas from across the nation. Some toured CMR, providing management recommendations. Public meetings were advertised by news media and phone calls. Letters were sent to individuals, special interest groups and federal, state and local government representatives. Meetings were held by FWS in Lewistown, Helena, Billings and Glasgow in April, 1978 and in Lewistown, Helena, Billings, Glasgow, Missoula, Jordan, Great Falls and Glendive in September 1979. $\mathrm{COE}$ also held meetings at Glasgow, Missoula, Lewistown, Glendive and 
Jordan. These efforts resulted in identification of specific resource problems and possible solutions, which are developed in the alternatives presented in this document.

This Environmental Impact Statement (EIS) was prepared in compliance with the National Environmental Policy Act of 1969 and in specific response to litigation filed in US District Court, for the District of Columbia, entitled Natural Resources Defense Council, Inc. et al. versus Rogers C. B. Morton et a1. (June 1975), which required the Department of Interior to write EISS for grazing management on 212 units of federal rangelands in the West, including CMR. The primary responsibility for writing these statements was given to BLM. However, on 27 February 1976, amendments to the National Wildlife Refuge System Administration Act (Public Law 94-223) were passed, giving BLM's jurisdiction of the refuge to FWS along with the responsibility for writing this statement. 


\section{ALTERNATIVES}

This chapter defines and evaluates five management alternatives for CMR and concludes with a comparison. Management alternatives for wilderness and minerals have been deferred until a later date; plans for managing 15 proposed wilderness areas comprising approximately 161,000 acres on CMR will be developed after Congressional action on these areas is taken. These plans will take into account such items as access, fire control, mining, visitor carrying capacity and wildlife habitat requirements. None of the alternatives compromises wilderness values of existing or proposed areas. Also, a specific management plan for prairie dogs will be prepared at the end of a current study, since adequate information is not now available.

Management actions for all alternatives must take into account special Legislative and Executive mandates for cultural resources and endangered or threatened species. Before any action is taken which may impact cultural resources, individual site surveys will be completed for each area; these requirements will be met under all alternatives.

Under Section 7 of the Endangered Species Act, a biological opinion will be rendered on effects of each alternative on endangered or threatened species present or thought to be present on the refuge. These procedures are in process and biological opinions have been requested (Appendix 1). In addition an assessment of impacts would be made on the proposed area from which black-footed ferrets would be captured for transplanting to the refuge.

Recreation proposals in all alternatives are a combination of proposals by FWS, COE and Montana Department of Fish, Wildlife \& Parks (MDFW\&P). A detailed description on each is available for inspection at the FWS office in Lewistown, Montana. All developments would be constructed with facilities for handicapped users as required by the Architectural Barriers Act of 1968, PL 90-480.

For analysis of wildlife habitat on CMR 17 indicator wildlife species in five major vegetative types (Fish and Wildlife Service 1979) were studied. Included were seven game species, seven nongame species and three furbearers (Appendix 2).

Although habitat requirements are different for various species on CMR, habitat deficiencies for many can be corrected by fulfilling requirements of sharp-tailed grouse, mule deer and pronghorns. For example, sampling data revealed that improving the habitat for sharptailed grouse alone will correct habitat for approximately 80 percent of all wildife species using the same habitat. Thus, sharp-tailed grouse, mule deer and pronghorns are referred to consistently throughout the document.

The majority of private and state inholdings are unfenced and in common with other land in the allotments administered by FWS, COE or BLM. Livestock stocking rates on these inholdings are determined by the landowner or operator as long as they are consistent with recognized livestock carrying capacities determined by a valid range survey and the season of use is the same as the rest of the allotment. If the owner or operator wishes to deviate from the grazing pattern of the allotment, 
the land must be fenced or other measures taken to insure the operations do not affect the majority landowners.

A mission statement and long range goals for CMR were approved by the FWS Regional Director in September 1978.

The mission of CMR is to preserve, restore and manage in a generally natural setting a portion of the nationally significant Missouri River breaks and associated ecosystems for optimum wildlife resources and provide compatible human benefits associated with its wildlife and wildlands.

CMR goals are to:

1) Attain and perpetuate a balanced, natural diversity of plant and animal communities favoring endangered or threatened species, then all other native species and finally desirable exotics.

2) Provide the habitat and necessary resources for recovery or reintroduction of species endangered or threatened with extinction, as recommended by approved recovery plans.

3) Protect and maintain Congressionally established wilderness areas and state and nationally designated historic, cultural and natural areas and objects unique to the Missouri River breaks and allow public use and enjoyment when compatible with wildlife goals.

4) Restore and maintain habitat and other conditions necessary to sustain optimum populations of mammals and nonmigratory birds.

5) Manage migratory bird habitats first for production and then for use during migration.

6) Preserve and protect the integrity of the nationally significant Missouri River breaks ecosystem.

7) Protect and maintain the natural resources of the Missouri River upstream from the Fred Robinson Bridge; to complement and enhance the nationally designated Upper Missouri National Wild and Scenic River.

8) Provide grazing for domestic livestock when compatible with wildife and habitat goals.

9) Provide public understanding and appreciation of the fish and wildlife, recreational, cultural and scenic resources on CMR through high quality programs in environmental education, interpretation, wildlife observation, hunting, fishing and other forms of wildlifeoriented recreation when compatible with wildlife goals.

10) Demonstrate and contrast management of wildlife through natural ecological processes, areas managed for maximum wildlife abundance and diversity and areas managed especially for compatible public uses of wildlife and wildlands.

11) Coordinate and integrate, where feasible, management of CMR with objectives of federal and state agencies and private landowners within and around CMR.

All alternatives must also address the existing wildlife, range and recreation objectives approved for CMR. These are: 
Wildlife objectives:

1) Reintroduce peregrine falcons and maintain two eyries by 1985 and a third by 2000 .

2) Maintain habitat for and reintroduce a minimum of six pairs of black-footed ferrets on six or more prairie dog towns as soon as animals are available.

3) Maintain existing migration habitat for bald eagles and determine feasibility of establishing a breeding population.

4) Improve and maintain sharp-tailed grouse habitat and habitat for associated species in good to excellent condition in the ponderosa pine-juniper, juniper and grass-deciduous shrub types on suitable areas to support 30 spring breeding birds/mi (males and females) by 2000 when weather, predation, life cycles or other natural factors permit.

5) Improve and maintain pronghorn winter habitat in good to excellent condition on suitable sites in the juniper and sage-grassland types to support 1500 wintering animals by 2000 .

6) Improve and maintain riparian habitat on the Missouri and Musse1 shell rivers and other suitable riparian areas in good to excellent condition by 2000 to benefit wildlife species such as white-tailed deer, raccoons, beaver, waterfowl, kingbirds, mourning doves, elk, American kestrels, ring-necked pheasants and turkeys.

7) Improve and maintain mule deer habitat on the refuge in the sage-grassland, ponderosa pine-juniper and grassland-deciduous shrub vegetative types in good to excellent condition to support over-wintering populations of $10 \mathrm{deer} / \mathrm{mi}^{2}$ by 2000 and in a manner that will also benefit sharp-tailed grouse.

8) Maintain viable prairie dog towns covering between 5000-20,000 acres on suitable areas with sizes and patterns desirable for black-footed ferrets. Learn the habitat requirements for species of special interest and concern that live on or in proximity to these prairie dog towns.

9) Maintain elk habitat in good to excellent condition and improve security cover to a level capable of maintaining a population of 2.5 over-wintering elk/mi ${ }^{2}$ in the coniferous and closely associated grassland communities by the year 2000. Minimize crop depredation on private lands.

10) Improve waterfowl habitat to good or excellent condition on all suitable ponds.

11) Reintroduce Rocky Mountain bighorn sheep into suitable habitat. Evaluate transplant success to determine the feasibility of continued stocking efforts.

Range objectives:

1) Improve climax range condition, productivity and stability of soil resources to complement and enhance wildlife objectives.

2) Provide forage beyond the needs of wildlife to domestic livestock where environmental limitations do not preclude such use. 
3) Provide stability and support to livestock users and their operations consistent with wildlife objectives.

\section{Recreation objectives:}

1) Identify, preserve and protect all cultural resource values in accordance with public law.

2) Continue to provide opportunities for the public to enjoy sport hunting, fishing and other wildlife/wildlands-oriented recreation, including interpretation and environmental education compatible with wildlife objectives and the overall refuge mission.

3) Continue other agency management of developed recreation areas for nonwildlife-oriented recreation, compatible with wildlife objectives. 
No management would be undertaken for black-footed ferrets, bald eagles or peregrine falcons. Bighorn sheep populations would be allowed to expand or decline as conditions warrant.

\section{HABITAT MANAGEMENT}

Wildlife surveys on CMR would consist primarily of aerial and ground surveys to determine pronghorn, deer and elk distribution, deer and elk population levels, sage and sharp-tailed grouse display ground locations and population levels, waterfowl production, colonial nesting bird production, beaver population trends, coyote densities, and prairie falcon and golden eagle use.

Nest structures for geese and five goose and duck brood ponds would be maintained near the old Slippery Ann headquarters. A second set of goose pens would be maintained at Fort Peck. A few scattered water developments would be constructed and maintained for wildlife and livestock and suitable ponds stocked with fish.

The existing small cooperative farming program on the Missouri River bottomlands in the west unit would be continued. Farming would be conducted on a sharecrop basis with one-third left for wildlife needs. Habitat conditions would be monitored by vegetative sampling.

All wildfires would be suppressed as soon as possible following discovery. Those that could be reached by vehicle would be fought with hand crews. Aerial retardant would be used if ground crews were ineffective. An exception to this policy would pertain to northern Petroleum County where fires would be allowed to burn so long as they remain confined to the drainage in which they originated. No prescribed burning would be used in this alternative.

Fisheries management would consist of cooperating with the MDFW\&P in stocking fish and enforcing regulations.

FWS would control predators to reduce livestock depredations on a case-by-case basis upon request of the livestock operator and confirmation of damage. No prairie dog or other small mammal control would occur on the refuge except for human health and safety purposes. Prairie dog control would be considered where refuge lands adjoin other landowners as a last resort when they are causing problems to the landowner. No coyote control would occur to protect other wildife.

\section{FORAGE ALLOCATION}

Livestock grazing would remain at current levels. Total federal Iivestock Animal Unit Months (AUMs) would be maintained at 60,108 with 3524 in a nonuse status. Vegetation for wildlife used for food, residual cover or other habitat needs would total about 50,000 AUMs. 
There would be a slight increase in total forage available for wildlife and livestock on a refuge-wide basis totaling approximately 110,000 AUMs by 1985 .

\section{RANGE DEVELOPMENTS}

Range improvements would continue at present levels with limited maintenance or new construction scheduled.

\section{RECREATION AND CULTURAL RESOURCES}

There would be minor improvements in existing recreation facilities. The 21-mile reach of the Missouri River downstream from the Upper

Missouri National Wild and Scenic River, between Fred Robinson Bridge and headwaters of Fort Peck Reservoir, would continue to receive limited recreation use.

Some improvement of the visitor contact station at Fort Peck would occur and wildlife pastures at Fort Peck would continue to be maintained by $\mathrm{COE}$.

Periodic maintenance of the existing self-guided wildlife tour route near Slippery Ann would occur. Existing access roads and recreation areas would be retained with limited maintenance or minor improvements. Private cabins would be retained.

Elk and pronghorn hunting would be on a limited (permit) basis while hunting for deer, upland game and waterfowl would be open to all license holders. The use of free elk archery permits would be continued to collect data on archery hunting. No aerial hunting for coyotes would be allowed. All fishing and hunting would be in accordance with state regulations, formulated cooperatively by MDFW\&P and CMR personnel.

\section{MITIGATING MEASURES}

Small scale fencing could occur on intermittent and continuous streams, ponds and draws to improve riparian habitat and shrubs. The only other mitigating measures would be to select all or a portion of the Proposed Action, Intensive Wildlife Management or No Grazing alternatives. 


\section{ALTERNATIVE B}

\section{(PROPOSED ACTION)}

\section{OVERVIEW}

The planning process was guided by the dual agency administration of FWS and COE (Appendix 3), the Executive Order establishing CMR (Appendix 4), national policy, information provided by the public and longrange CMR goals. The Proposed Action is considered to be a practical solution that provides almost all of the wildlife habitat benefits of any of the alternatives. These benefits would take longer to occur but could lessen off-refuge impacts. Considering the dual jurisdiction and land ownership patterns, it appears to be the most reasonable alternative.

The following constraints were established by FWS to govern the Proposed Action. To the extent these constraints are imposed by policy and not legislation, they are subject to change through public evaluation of this EIS.

1) FWS funds will not be spent for livestock where wildlife benefits cannot be identified in the process.

2) Water developments, fencing, farming, etc., are generally inconsistent with wildlife goals and will only be used when wildlife objectives cannot be accomplished through other measures.

3) Restoration practices such as soil ripping and shrub planting are consistent with wildlife objectives.

4) Insofar as possible, FWS will coordinate and standarize CMR livestock grazing systems, stocking rates and seasons of use with adjacent landowners in common allotments so long as this does not prevent FWS from carrying out its mandates.

5) Public hunting, fishing and trapping are appropriate uses of CMR lands as long as they are consistent with CMR's objectives.

\section{General}

Clarification of conflicting legislation and management responsibilities between COE and FWS would be sought. A cooperative effort with COE would be launched to determine ownership of all lands within the CMR boundary. These areas are generally associated with COE purchases made in the 1930's for the Fort Peck project and title to some of these parcels is unknown.

The Proposed Action alternative would reach and maintain the refuge objectives. A 33 percent reduction in grazing would occur by 1985 . Generally, the refuge would be grazed on a seasonal or continuous basis at light livestock stocking levels and the response of wildlife habitat closely monitored. If wildlife objectives were not being accomplished additional changes in grazing would be implemented on specific areas not responding. These actions would include further reductions or increases in AUMs allocated to livestock, changes in seasons of grazing use and other changes. 
It is estimated that it will take 5-15 years depending on the weather conditions and site characteristics before adequate information is available to make these changes or estimate impacts.

\section{ENDANGERED OR UNIQUE SPECIES INTRODUCTION}

Two peregrine falcon reintroductions would be made at suitable sites and six pairs of black-footed ferrets and several pairs of swift fox would be reintroduced on selected prairie dog towns as animals become available. No known source of black-footed ferrets exists at present. Twenty to thirty bighorn sheep would be introduced at selected sites. Introductions would continue as necessary to establish viable populations.

\section{HABITAT MANAGEMENT}

An essential undertaking would be preparation of a habitat management plan for each allotment by 1985. These plans would spell out specific wildlife habitat problems and provide specific management actions to correct the problems, such as grazing seasons of use, prescribed burning, ripping, planting and rest from grazing if necessary. Evaluation of wildlife habitat on a periodic basis to determine whether wildlife objectives were being met in a suitable time frame would occur. This would be coordinated with BLM in joint pastures. It is recognized that BLM and FWS have different management objectives for livestock grazing. Fences would be constructed where necessary to achieve each agency's objectives. The location of these fences would be determined when habitat management plans are written for each allotment. Fortyseven miles of boundary fence have been identified and are discussed further in range developments. These fences would not necessarily be on the refuge boundary. They could be constructed in the best and most practical locations. Other possibilities would be to locate new water facilities or implement specific grazing systems designed to reach each agency's objectives in suitable common allotments.

The Habitat Evaluation criteria (Appendix 2) would be upgraded as more information becomes available. In addition, various sampling techniques would be established to monitor at prescribed intervals longterm changes in habitat and range conditions. Different treatments or grazing capacities would be employed if these evaluations indicated that wildlife objectives were not being reached. Other management surveys would be as described under the No Action alternative.

The most significant management actions to achieve habitat objectives would be reductions of livestock grazing, changing livestock seasons of use and habitat treatment practices such as prescribed burning and soil ripping. Overall proposed livestock levels would be approximately 33 percent below current federal AUM levels on the refuge. Livestock grazing would be utilized on a prescription basis, as required, to maintain existing plant communities at desired habitat conditions.

Deciduous shrub quantity and quality would be increased by pre- 
scribed burning on 1900 acres by 1985 and a total of 7700 acres by 2000 . Planting would be done on 100 acres by 1985 and a total of 500 acres by 2000. Habitat analysis indicated deciduous shrub communities are in short supply on the refuge and historical accounts indicate shrubs were once more abundant than they are today. A combination of actions would be taken to improve the present situation. Although a better shrub community could be attained it would not be luxuriant as CMR does not have the potential, with limited exceptions, to provide such communities. The aforementioned habitat management plans would determine the best means of re-establishing shrubs on each allotment. Management actions would probably be adjustments in grazing, burning and planting in that order. Shrubs would be planted to re-establish a seed source for natural revegetation. It is estimated that this would involve approximately 25 acres/year depending on success of grazing adjustments and burning.

Following burning, planting or ripping there would be no grazing allowed for two to three years or longer if necessary to ensure successful establishment of the desired vegetation.

Cooperative farming would be phased-out in the bottoms along the Missouri River to restore natural river bottoms. Lure cropping would be implemented on the east end to decrease elk depredation on adjoining private croplands. Six miles of fence enclosing about 900 acres would be constructed from 1980-2000 to protect selected riparian zones from livestock and enhance shrub reproduction.

Since actions to be undertaken would be constrained by the interspersed ownership of federal, state and private lands, several priority land purchases totalling approximately 2000 acres would be attempted on a willing-seller basis by 1985. Additional purchases would occur as money becomes available. Two allotments would be changed from domestic sheep to cattle use by 1985. These allotments are located in the potentially best pronghorn range on the refuge, but where pronghorn habitat components are depressed. Switching to cattle use would eliminate the dietary overlap between sheep and pronghorns and improve habitat values for pronghorns. Domestic sheep would be eliminated from the refuge unless needed on a prescription basis to manipulate vegetation.

A policy for fire management would include the following points: 1) No prescribed burning on most shale and badlands sites, 2) no prescribed burning along the refuge boundary when opposed by adjacent owners, 3) little or no prescribed burning on slopes in excess of 60 percent, 4) prescribed burns of 10-40 acres each on the west half of the refuge, 5) suppress all fires in coniferous communities on the eastern portions of the refuge where conifers are limited in extent, 6) suppress wildfires in identified critical elk calving, sage grouse and mule deer winter habitats where fire may destroy desirable habitat components, 7) rehabilitate wildfire burns by planting native browse species on suitable sites when necessary, 8) attempt to suppress wildfires in close proximity to recreation areas where recreation values may be jeopardized and 9) generally attempt to limit wildfires to 10-40 acres in dense timber which is an optimum size burn for deer and elk. This size burn 
may be impractical due to topographic and other factors. Burn sizes may actually be 80-100 acres or more.

Fisheries management would consist of cooperating with MDFW\&P in stocking programs and enforcement of fishing regulations while trying to protect water courses and revegetate any streambanks in poor condition.

Predator control to reduce livestock losses would be the same as the No Action alternative. Coyote control to benefit other wildife species would occur as a last resort as stated in the Final EIS for Operation of the National Wildlife Refuge System. Several methods of control are listed with killing of coyotes last. Small mammals would be controlled only if a health hazard was apparent. Prairie dog control would also be the same as the No Action alternative pending outcome of an ongoing study.

\section{FORAGE ALLOCATION}

Livestock grazing on CMR would be substantially reduced to improve habitat conditions for wildlife. Proposed livestock grazing levels would be 40,482 federal AUMs by 1985, which represents a 33 percent refuge-wide reduction from present federally licensed AUMs. Each allotment was examined in terms of existing range conditions (Appendix 8, 9), slope and water factors (Appendix 15), soil limitations (Appendix 7) and wildlife habitat conditions (Appendix 2). Stocking rates were then calculated for livestock based upon these factors to achieve a light grazing level (0-35 percent utilization) determined to be consistent with wildlife objectives. This reduction would range from 0-100 percent, depending on the allotment (Appendix 5). Three small livestock allotments would be eliminated and four allotments would be incorporated as pastures into other allotments held by the same pernittee.

Most livestock grazing would continue to be on a seasonal (winter, spring, summer or fall) or continuous (late spring through fall) basis, although spring turn-in dates would be later and grazing reduced to light stocking levels. In some cases prescription grazing would be employed as a management tool to provide certain habitat conditions to benefit a particular wildlife species.

In general there would be no early spring use in allotments currently under continuous or seasonal livestock grazing. Turn-in dates for livestock would be delayed until significant conflicts with wildlife would be avoided (late spring).

Several allotments have been identified as possessing potential for combination into deferred rotation systems with BLM, state and private landholders. Early spring use in existing pastures would be rotated with other pastures inside or outside CMR to eliminate spring use in the same pastures on a recurring annual pattern. Close cooperation, especially between BLM and FWS, would be needed on common pastures to ensure successful implementation of any deferred grazing systems.

Changes in one and possibly two existing rest-rotation systems would be considered. Two allotments with rest-rotation systems were identified which are not providing desired results in terms of habitat values. Recommendations made by Hormay (1980) would be considered when 
management plans for the allotments are written. Periodic evaluations of how these grazing systems are providing desired habitat quality for wildlife will ultimately determine the degree to which rest-rotation would be used as a viable grazing system on the refuge.

Generally, the other allotments with deferred and rest-rotation grazing systems would remain intact to provide a rest period during a portion of the grazing sequence with grazing commencing at different dates in succeeding years in a given pasture. Early spring use would be avoided as much as possible on these allotments because of soil erosion problems. Present turn-in dates would not be substantially affected under deferred or rest-rotation systems of use so long as the same pastures would not be grazed at the same time each year.

In years of below average forage production due to drought, fires, insects or other natural causes, grazing permits may be suspended in whole or in part as necessary.

\section{RANGE DEVELOPMENTS}

Most grazing allotments on CMR adjoin unfenced state and BLM land. Preparation of habitat management plans would involve intensive coordination with other landowners, especially BLM, to determine specific management actions necessary to meet the individual landowner's objectives. Boundary fences would be built where necessary. Fences would be 42 inches high, three strand with 12 inches between wires. The bottom wire would be 18 inches above the ground and smooth in areas where pronghorns would likely encounter fences.

Approximately 47 miles of fencing are proposed along the CMR boundary to keep livestock numbers within authorized levels. Fencing would occur in a minimum of six allotments by 2000. Other portions of the boundary would be fenced if problems arise regarding unauthorized livestock use. A limited amount of interior fence would be built.

New water development projects would be limited to facilities that enhance watershed, wildlife or recreation programs. A need for three new stock ponds plus one pipeline and several troughs has been identified. Soil ripping would occur on as much as 10,000 acres of suitable panspots and dense clay range sites to improve vegetative productivity. Periodic maintenance of existing range developments would occur on an as-needed basis.

\section{RECREATION AND CULTURAL RESOURCES}

Public access would be provided to various portions of CMR (Fig. 1) and water access by boat and plane throughout the length of the refuge would be stressed.

Among new programs would be enhancement and preservation of the Missouri River below the nationally designated segment from Fred Robinson Bridge to headwaters of Fort Peck Reservoir. FWS would work with $\mathrm{COE}$ in recommending operation of Fort Peck Dam and Reservoir in a manner which would tend to limit water level fluctuations to enhance recreation and fisheries opportunities both on the reservoir and in this 
segment of the river as conditions permit.

A cooperative management plan would be prepared with BLM, COE and MDFW\&P for the Slippery Ann area by 1982. Of special concern would be nearby sites that could replace or complement James Kipp State Park which is periodically flooded, the existing wildlife tour route, needed provisions for accommodating floaters who use the Upper Missouri National Wild and Scenic River and an interagency visitor contact-interpretive center. Visitor contact stations would be constructed at Fort Peck, Malta and Lewistown in cooperation with other interested agencies such as COE, BLM, MDFW\&P and Montana Department of State Lands (MDSL).

An historic tour route would be designated along the Sand Creek trail south of the Missouri River. Various historic buildings and sites located along this route would be marked and interpreted.

A scenic tour route following the existing Knox Ridge road would focus attention on the Missouri River Valley and its associated wildlife.

Certain lands such as research natural areas, paleontological areas, islands and special wildlife areas would be identified as environmental education study areas for use by various institutions and organizations. York Island, a site on Fourth Point and a limber pine community near Hell Creek State Park would be designated as research natural areas on the eastern portion of the refuge because of their unique plant communities. A coniferous forest community 1ying east of the mouth of Two Calf Creek on the west portion of the refuge would be designated as a research natural area because of its vegetative features.

From Fred Robinson Bridge to Crooked Creek Recreation Area, a 50mile self-guided canoe trail (about 25 miles along the undesignated free-flowing segment of the Missouri River and another 25 miles from headwaters of Fort Peck Reservoir to Crooked Creek) would be established, paralleling the route followed by Lewis and Clark. Where possible, natural, historic and other features would be interpreted along the route.

A 140-mile sail-powerboat tour route would be designated on Fort Peck Reservoir, connecting existing and proposed major recreation areas. In addition to a brochure describing the route and points of interest along the way, signs and markers would be placed at campsites and boat access areas along the shore.

At appropriate locations on the refuge, exhibits would be provided to explain wildlife, geologic, historic and related features.

As recreation demands and needs dictate, approximately 30 miles of backcountry (nonmotorized) and nature trails would be designated at several locations. These trails would be self-guiding or could be used as part of a guided interpretive program.

As with the No Action alternative, wildife pastures would continue to be maintained by $\mathrm{COE}$ at Fort Peck. Interpretation of the wildlife display pastures would be integrated with the visitor contact station at Fort Peck. Existing private cabin areas would remain and no new cottage areas would be developed.

All existing roads and trails including those that have been closed 
UNITED STATES DEPARTMENT OF THE INTERIOR

LEGEND

CHARLES M. RUSSELL

NATIONAL WILDLIFE REFUGE

ENVIRONMENTAL STATEMENT

- Fws Headquartiers

Corps of Enginerers Headquarnats

Privere Cabins

Research Natural Area

Tronsoorterion System

* Knox Ridge Scenic Tour Roure

RECREATION PROPOSALS

-.-2 UL Bend Wilderness \& Exisung

- Nature Trall

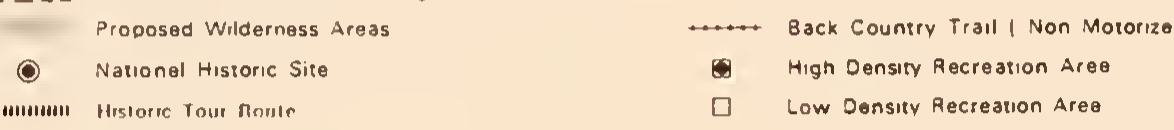

- High Density Recreation Area

De

Note Forl Peck Recreation Areas Incluer

Aut Force Park

Brg Murdiy
Downstreain

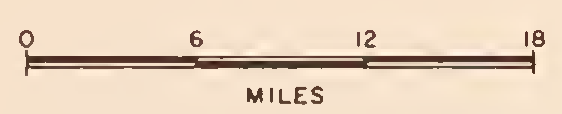

Dededgn Cints

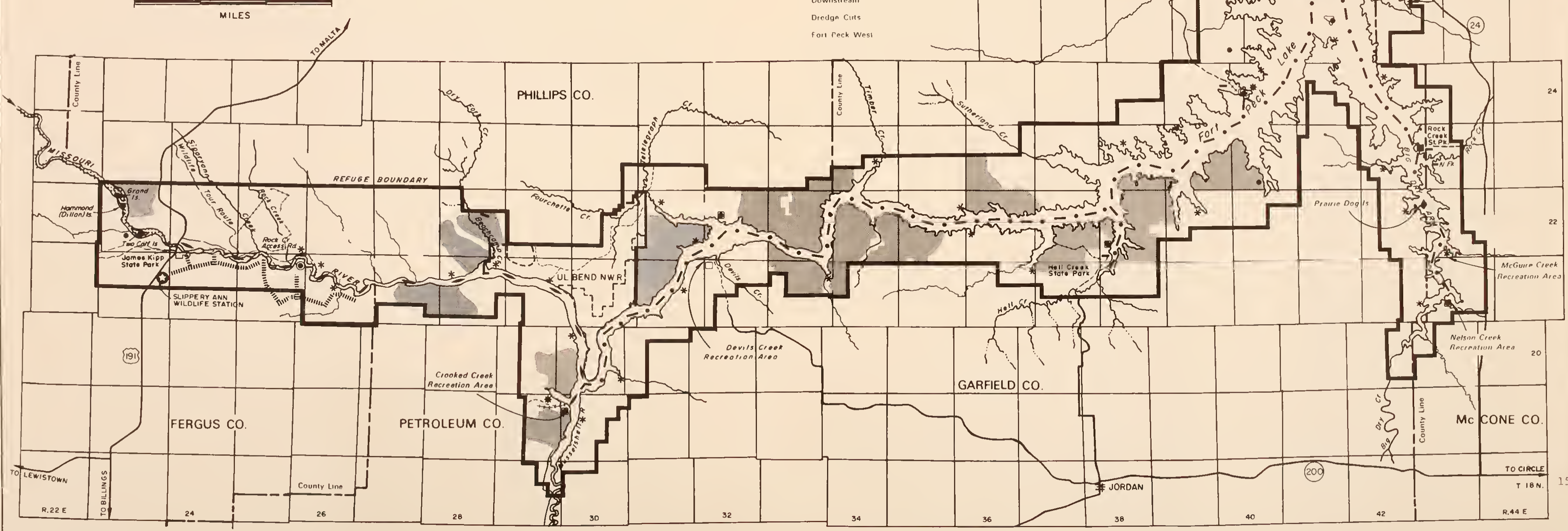



would be evaluated to determine those that should be improved, realigned or closed. Established roads would be marked to guide visitors.

Cooperative agreements would be negotiated with affected agencies to ensure that connecting roads outside CMR were maintained.

Where compatible with wildife and in consultation with COE, areas for float plane landings on Fort Peck Reservoir would be established as needs dictate.

An additional boat launching, camping and fishing access site would be developed at Fourchette Bay on the north side of the reservoir. As demands increase, facilities would be expanded by COE at existing recreation areas. Some access roads leading to these sites would be improved.

Wildlife populations would be harvested within the capacity of the resource. Primitive sport fishing access sites would be provided at a number of locations throughout the refuge.

Qualified cultural structures and sites would be officially designated through nomination to the National Register of Historic Places or to other appropriate lists. Surveys of the areas would be conducted to comply with Executive Orders or legislation as funding and manpower permit.

\section{MITIGATING MEASURES}

If wildlife objectives were not being accomplished under the Proposed Action, several courses of action would be available. As ranches were sold, grazing privileges could be retired across CMR until approximately 15-20 no-grazing areas were established. These no-grazing areas would be used by cattle from other actively grazed allotments needing rest to produce desired vegetation. Once accomplished, this would contribute to the objective of stabilizing livestock use. Operators would always have a place for their cattle to graze. In drought years some use could be made of these areas when the normally grazed areas would not produce enough vegetation for wildlife and livestock. If constraints listed at the beginning of this alternative were softened to allow construction of stock ponds, fencing and other management facilities, options would be available to mitigate some impacts on individual ranchers as well as allow suitable farming and still reach or exceed wildlife objectives. Presently, however, stock ponds, fencing and farming are generally inconsistent with refuge goals and are not available as mitigating measures. If these options were available, ponds at heads of draws would be fenced, eliminating trampling of shrubs by livestock.

Another measure would be to fence riparian zones (intermittent streams, river banks and reservoir shorelines) where desired results were not being obtained. These have traditionally been considered as sacrifice areas on CMR due to concentrations of livestock that occur from normal grazing operations. To restore and maintain the all important riparian areas without fencing, livestock grazing would have to be eliminated in the entire allotment where it occurs (Hormay 1976).

Farming on the uplands and some bottoms, if done properly, could greatly benefit wildlife on CMR, especially turkeys, ring-necked pheasants, white-tailed and mule deer, elk, sharp-tailed grouse, raccoons, 
gray partridge, waterfowl, sage grouse, white-tailed jackrabbits and most seed eating birds. This management practice is also not available due to the policy constraints placed on this alternative.

The areas needing wildlife habitat improvement on the refuge could be placed in a no-grazing category for several years then grazed by livestock as stated in the proposal. This would improve habitat conditions in a shorter time period.

AUM reductions could be spread over a longer time period than five years which would reduce, but not eliminate, impacts to some livestock operators using the refuge but would delay wildlife habitat improvement.

Any new facility construction to improve wildlife habitat, range resources or recreation quality would be carefully evaluated to ensure that all site limitations are known and considered before construction is attempted.

If recreation activities result in significant conflicts with wildlife, actions would be taken as necessary to solve the problem. 


\section{ALTERNATIVE C}

\section{(INTENSIVE WILDLIFE MANAGEMENT)}

General

This alternative involves several interrelated components, reducing grazing to approximately 27,000-30,000 AUMs, purchasing all inholdings to control grazing, removing private cabins, and intensive wildlife habitat manipulations. Under this alternative, AUMs would be allocated to livestock as needed for vegetative manipulation. The legislative conflicts between COE and FWS would have to be resolved in favor of FWS to remove the private cabins. Purchasing all private and state inholdings would require condemnation of some private lands and a change in SLB policy to allow state land to be sold. These land purchases together with fencing of the entire refuge boundary and carrying out the intensive wildlife habitat manipulations that provide the increases in wildlife benefits, would require approximately a 30 million dollar increase in the refuge budget, which is unlikely. The intensive wildlife habitat manipulation proposals such as fencing, farming and pond development would require a change in FWS policy.

\section{ENDANGERED OR UNIQUE SPECIES INTRODUCTION}

Reintroduction of peregrine falcons, black-footed ferrets, swift fox and bighorn sheep would occur as in the Proposed Action alternative. Buffalo would be introduced at UL Bend on 30-35 sections of enclosed land.

\section{HABITAT MANAGEMENT}

Management surveys would be conducted similar to those proposed under the No Action alternative with slight expansion in number of species sampled and intensity of sampling. Facilities for geese at Slippery Ann and Fort Peck would be maintained. Additional waterfowl production areas at UL Bend would be created through damming natural runoff water into 34 ponds and associated wetlands totaling approximately 900 acres.

Special studies would be undertaken for burrowing owls and mountain plovers. Habitat analyses would be conducted as stated under the Proposed Action alternative.

Livestock grazing would be used as a management tool on a prescription basis to remove rank vegetation or to alter vegetation to reach desired habitat conditions for wildlife. Extensive burning, planting, prescription grazing and cultivating suitable land would be the main management tools under this option. To implement this grazing pattern all private and state inholdings would have to be acquired. At present the majority of inholdings are unfenced. Fencing the many isolated parcels would be impractical and expensive if private and state lands were to be retained under present ownership and grazing practices. 
Shrub quantity and quality would be increased from fair to excellent condition by burning 3800 acres by 1985 and a total of 15,000 acres by 2000. It is estimated that shrub planting would be carried out on 800 acres by 1985 and on a tọtal of 3000 acres by 2000. In addition, intensive farming would be conducted on approximately 2000 acres of land to provide food interspersed with shelterbelts and other cover for deer, upland birds, elk and other wildlife. This would include substantially increasing farming in some river bottoms and other suitable areas to increase the food supply for white-tailed deer as well as many other riparian species. Some minor riparian zones across CMR would be excluded from big game use by temporary fencing. This would allow these zones to revegetate and provide excellent quality habitat at which time the fencing would be removed.

Elk lack adequate security cover from Timber Creek (west) to Fort Peck; this would be corrected by planting ponderosa pine at various 1ocations. Fire management would be the same as the Proposed Action alternative except some prescribed burns would be made on the east half of the refuge in Garfield County.

Fisheries management would include stocking and regulations enforcement as outlined in the Proposed Action alternative, as well as protecting water courses and revegetating impoverished areas. In addition some bays would be diked off to establish littoral vegetation for spawning and concrete spawning runs would be established for use by salmonids.

Control of predators to protect livestock and control of prairie dogs would be the same as the No Action alternative. Coyote and small mammal control to benefit other wildlife species would occur as a last resort as stated in the Final EIS for Operation of the National Wildlife Refuge System (Fish and Wildlife Service 1976) and the Draft Migratory Bird Program Management Document Goal 非5 (Fish and Wildlife Service 1979).

\section{FORAGE ALLOCATION}

Livestock grazing would be employed as a tool to achieve or maintain desired habitat conditions. Generally, livestock would be grazed at moderate levels with alternate spring-summer use. Each year of use would be followed by two years' complete rest. Site specific treatments would vary depending on wildlife species' needs and the condition of the vegetation. Treatments would include specific grazing prescriptions and other habitat treatments such as fire. Federal livestock levels grazed on an annual basis would be approximately one-third those presently authorized. About 23,000 AUMs would be provided for livestock use by 1985. As private and state inholdings are acquired, prescription grazing would be applied. Wildlife would receive about 87,500 AUMs by 1985 to fulfill habitat needs.

By 2000 there would be an estimated maximum of 27,000-30,000 1ivestock AUMs grazed on CMR annually. Wildlife would receive the bulk of the annual forage production (about 107,000 AUMs) for food and habitat requirements. 
Range improvements would be limited to approximately 400 miles of boundary fence to regulate livestock. Interior fencing would be removed in smaller pastures and water facilities would be maintained where needed. Range improvements such as fences or ponds on marginal sites having soils, geologic hazards or wildlife conflicts would be removed or allowed to deteriorate. Soil ripping would occur on nearly all suitable sites (38,000 acres) on the refuge, with the exception of wilderness areas, to improve wildlife habitat and reduce soil erosion.

\section{RECREATION AND CULTURAL RESOURCES}

This alternative is similar to the Proposed Action alternative for recreation. However, there would be a somewhat lower level of public use and facility development.

Unlike the Proposed Action alternative, no backcountry (nonmotorized) trails would be developed and only nature trails would be provided.

Private cabins presently situated on CMR at The Pines, Fort Peck, Rock Creek State Park and Hell Creek State Park would be removed as the leases terminate. The areas would be rehabilitated into suitable wildlife habitat.

There would be no development of low density recreation areas; additional fishing access sites would be provided instead. Existing high density recreation areas would be expanded by COE as needs dictate. Any recreational uses or activities conflicting with normal wildlife activities would be controlled by excluding such use during critical seasons.

Any new facility construction to improve wildlife habitat, range resources or recreation quality would be carefully evaluated to ensure that all site limitations are known and weighed in terms of whether or not the proposed construction would be feasible.

\section{MITIGATING MEASURES}

Retirement of all livestock grazing in a given area could be employed if competition with wildlife is determined to be a limiting factor affecting a wildlife species.

Gradual reductions in the livestock grazing program would soften impacts of reduced livestock levels on individual operators but would delay wildife habitat improvement. 


\section{ALTERNATIVE D}

(MULTIPLE USE)

\section{General}

This alternative would not be possible to implement unless Congressional action changed CMR from a national wildlife refuge to a multiple use management area.

\section{ENDANGERED OR UNIQUE SPECIES INTRODUCTION}

Reintroduction of peregrine falcons, swift fox and bighorn sheep would occur as in the Proposed Action alternative. One or more pair of black-footed ferrets would be reintroduced, if they are available.

\section{HABITAT MANAGEMENT}

Management surveys would continue as described in the No Action alternative, as would development of areas for geese at Slippery Ann and Fort Peck. Waterfowl ponds and nesting structures would be expanded at UL Bend through damming of natural runoff waters to include 34 ponds and associated wetlands totaling about 900 acres.

Grazing would be initially reduced and then gradually increased over current levels as range conditions improve and portions of the riparian zone along the Missouri River would be grazed on a prescription basis. Cooperative farming would continue as described under the No Action alternative or be increased.

Ten miles of fence would be constructed along riparian zones of several smaller streams to exclude livestock. Prescribed burning would be done on 400 acres by 1985 and a total of 1500 acres by 2000. Shrub planting would be done on 100 acres by 1985 and a total of 300 acres by 2000.

No trees would be planted to increase security cover for elk, no land would be purchased. All wildfires would be controlled in coniferous communities as described under the No Action alternative. Prescribed burns would be set in the sage-greasewood-grasslands to enhance grass and forb production. Fisheries management would be as stated in the Proposed Action alternative.

Predator control to reduce livestock losses would occur under the same guidelines as on adjacent land, including aerial gunning. Prairie dog control would be as stated under No Action. Other small mammal control would be as stated under Intensive Wildlife Management. Coyote control to protect other wildlife would be as stated under the Proposed Action.

\section{FORAGE ALLOCATION}

Livestock would receive approximately one-half the allocated forage. Initially there would be temporary reductions in present livestock AUMs from 56,000 active to 52,000. UL Bend and Rock Creek ungrazed 
areas would be opened to livestock grazing. Temporary livestock nonuse of allotments in deteriorated condition and soil ripping of all suitable panspots and dense clay sites would provide a forage increase of several thousand AUMs for livestock and wildlife over present levels because of improved range conditions. Wildlife would ultimately be allocated about 60,000 and livestock 61,000 AUMs on federal lands within the refuge.

\section{RANGE DEVELOPMENTS}

As many as 12 additional allotments would have new grazing systems implemented by 2000. The six allotments presently in rest-rotation systems and the three deferred rotation systems would be maintained.

Range improvements such as fencing, water development or mechanical treatment of soils would be based upon allotment needs.

\section{RECREATION AND CULTURAL RESOURCES}

All recreation proposals discussed in the Proposed Action alternative would occur. In addition, a backcountry foot and horse trail extending the length of CMR on the north side of the Missouri River would be designated. This trail would provide the closest land route paralleling the historic Lewis and Clark trail. Some primitive campsites would be located along this route and historic and natural features would be interpreted. The trail would be nominated as part of the National Trail System in conjunction with the previously designated Lewis and Clark Trail highway route established by the National Park and Recreation Act of 1979.

A perimeter shoreline scenic road extending 21 miles along the north shore of Fort Peck Reservoir on the east side of the refuge would be constructed. The road would be built by $\mathrm{COE}$ near the lakeshore to provide optimum viewing opportunities. Primitive campsites would be established at a number of locations throughout the refuge. High and low density recreation areas described for the Proposed Action alternative would be expanded as needs dictate.

\section{MITIGATING MEASURES}

Fencing riparian zones and ponds where no rotation systems are employed would encourage development of riparian communities. Otherwise, vegetation in these important locations would not attain desired levels.

Implementation of several new rotation grazing systems on the refuge should provide some increased habitat quality and may eliminate the need to fence riparian areas in allotments with rotation systems.

Livestock allotments not meeting management goals could be placed in a nonuse status for as long as needed to achieve desired results. Operators would be required to accept nonuse or take use in another portion of the refuge.

Habitat manipulation treatments would be provided if needed to maintain a diversity of habitat conditions to favor certain wildlife species. The proposed levels of livestock grazing would limit 
wildife habitat potential. An improvement would occur under this alternative but the amount of improvement over present levels would be slight.

Any new facility construction to improve wildlife habitat, range resources or recreation quality would be carefully evaluated prior to work initiation to ensure that all site limitations are known. 


\section{ALTERNATIVE E}

(NO GRAZING)

\section{General}

This alternative would not be possible to implement unless Executive Order 7509 was changed. The Executive Order requires that excess forage be allocated to livestock and this alternative allocates none. The purchase of all private and state lands would require changes in SLB policy and tremendous increases in funding as stated in the Intensive Wildlife Management alternative.

\section{ENDANGERED OR UNIOUE SPECIES INTRODUCTION}

Reintroduction of peregrine falcons, black-footed ferrets, swift fox and bighorn sheep would occur as in the Proposed Action alternative.

\section{HABITAT MANAGEMENT}

Management surveys and habitat analyses would be implemented as stated under the Proposed Action alternative.

Prescribed burning of 11,300 acres would enhance vegetative productivity, particularly for forb and shrub species. In addition, 500 acres would be planted to shrubs and six miles of temporary wildlife exclosure fence would be constructed around acreage totaling 960 acres; 2000 acres would be cooperatively farmed. Ponderosa pine would be planted to fulfill elk habitat requirements. All private and state lands would be acquired through purchase or exchange.

Fire suppression would be as outlined in the Proposed Action alternative. Prescribed burning would follow guidelines described in the Proposed Action with the following exceptions: some prescribed burns would occur in coniferous communities in Garfield County. Fisheries management would be as stated in the Proposed Action alternative.

Prairie dog and small mammal control would be the same as the No Action alternative. Coyote control would occur as required for the benefit of other wildlife species. There would be no predator control on the refuge to protect livestock as no livestock would be present. Predator control to reduce livestock losses on adjacent lands would be as stated in the No Action alternative.

\section{FORAGE ALLOCATION}

Livestock grazing would be reduced by about 10 percent annually through 1985 on federal lands. All federal AUMs would be retired by the year 2000. Private and state inholdings would be purchased or acquired through exchange and these AUMs would be retired by the year 2000 .

All forage produced beyond plant and soil resource needs would be available for wildlife food and cover. Range conditions would improve substantially and essentially all the good condition range would be in 
excellent condition by 2000. This would provide wildlife food and cover.

\section{RANGE DEVELOPMENTS}

Range improvements would involve soil ripping as much as 10,000 acres of panspots and dense clay range sites to improve vegetative productivity for wildlife food and cover. A few larger reservoirs would be maintained for waterfowl production and, in some cases, fishing. Nearly all other range improvements would be removed or allowed to deteriorate. The refuge boundary would be fenced to prevent unauthorized livestock use. All fences would be constructed as stated in the Proposed Action alternative.

\section{RECREATION AND CULTURAL RESOURCES}

There would be no additional facility development or changes from the Proposed Action alternative.

Any new facility construction would be evaluated prior to work initiation to determine site limitations and whether or not the proposed project would meet the desired objective in view of known site limitations.

\section{MITIGATING MEASURES}

If habitat quality for wildlife species associated with seral vegetative communities declined, treatments such as prescribed burning, chemical treatments with herbicides or plowing could be employed to promote habitat diversity to benefit these species.

Gradual reductions in livestock levels would soften the impact upon livestock operators but would delay wildlife habitat improvement. There would be no other mitigating measures to help the livestock operators. 


\section{COMPARISONS OF ALTERNATIVES}

It must be recognized that a complex and controversial situation occurs at CMR due to Fort Peck Dam and Reservoir, state and COE recreation areas, the town of Fort Peck, private and state inholdings and past management practices where livestock was equal or dominant to wildlife (the 1952-53 range survey allocated 62 percent of the total AUMs to livestock and 38 percent to wildlife).

The Proposed Action alternative would attain habitat objectives for wildlife refuge-wide by 2000. In addition elk and pronghorns would receive additional benefits as they move on the refuge for part of their life cycle. The refuge would be managed in a natural setting for the most part, with intensive wildlife habitat and range improvement programs held to a minimum. Livestock grazing would be permitted under a seasonal or continuous use basis at light stocking levels. Prescription grazing would be used in those areas where light stocking rates were not satisfactory. Generally, this level of grazing has been determined to be consistent with wildlife objectives. This would be accomplished at moderate cost, with significant increases in wildlife values.

Although it is the most desirable for wildlife, the Intensive Wildlife Management alternative would destroy the naturalness of the refuge and be exceedingly costly to implement. Purchasing all private and state inholdings would require condemnation of some private lands, a change in SLB policy to allow state land to be sold and a change in FWS policy to allow intensive habitat manipulation such as farming, fencing and pond development. Removal of private cabins would require that the FWS-COE legislative conflicts be resolved in favor of FWS.

Livestock would be utilized as a management tool to achieve desired habitat conditions and wildlife objectives by 2000 or before. Excluding costs for fencing and land treatments, costs of acquiring all state and private inholdings inside the refuge would exceed $\$ 25.5$ million alone to allow implementation of the grazing program. However, the consolidation of these inholdings into federal ownership would allow CMR to be managed as a total refuge. Also, cooperative farming would provide key areas of increased diversity and food sources for wildlife.

As compared to the Proposed Action, changes in livestock numbers under Intensive Wildlife Management would not significantly enhance wildlife habitat unless all other proposed treatments were also provided. However, intensive developments as proposed by the Intensive Wildlife Management alternative are inconsistent with current policy constraints. On a dollar for dollar basis, the Proposed Action provides a greater benefit to wildlife than Intensive Wildlife Management. Wildlife objectives refuge-wide would be met or exceeded before 2000 .

The Multiple Use and No Action alternatives do not provide a wildlife refuge situation. Livestock grazing would be equal to or above wildlife for resource allocations. While popular with area or regional residents, these alternatives fall short of accomplishing the wildlife habitat potential of CMR. Management under Multiple Use could occur only if changed by Congressional action.

The complete elimination of livestock from the refuge under the No 
Grazing alternative or severe reductions in the Intensive Wildlife Management alternative would likely cause wildlife habitat adjacent to the refuge to decline as livestock operators attempt to make up for forage no longer available from federal lands by increasing stocking levels on private lands. Private land closures to public use, already a problem in the area, could be expected to accelerate, further jeopardizing farmer/recreationist/state/federal relations. As with the Intensive Wildife Management alternative, land purchase and total fencing of the boundary would be expensive and the additional benefits gained for wildlife would be slight. Wildlife objectives would be met or exceeded by 2000 for most wildlife species.

Recreation would continue with no major change or emphasis from present management under the No Action alternative. Under the other alternatives there would be more emphasis on providing the public an opportunity to enjoy compatible wildlife recreation. Roads to recreation areas, additional fishing access sites, expansion of some existing recreation areas, development of a scenic tour route and interpretive facilities, preservation of cultural resources and a new recreation area on Fourchette Bay are proposed for all but the No Action alternative. A notable difference under the Intensive Wildlife Management alternative would be the elimination of private cabins from the refuge. The Mu1tiple Use alternative proposes additional recreation development.

Except for the No Action alternative, participation in wildlife-oriented recreation activities would be expected to increase, as wildlife populations increase, due to the greater opportunities for viewing, photographing and hunting. Due to the remoteness of the area, rising costs of fuel for transportation, the small increase in population that is projected and competing recreation resources in the region, recreation use on CMR is not expected to significantly impact wildlife under any of the alternatives. Table 1 summarizes how the alternatives would impact the major areas of concern at CMR.

\section{SOCIOECONOMIC COMPARISONS}

None of the various alternatives has significant effects on income in the six-county region from recreation (Table 2). Predicted additional recreation income stems largely from increases in visitation.

The Multiple Use alternative would affect regional employment by the largest amount during the time period 1978-85, while the No Grazing and Proposed Action alternatives would have the greatest impact during the 1986-2000 period (Table 2).

Table 3 summarizes regional effects of the various alternatives due to grazing changes.

The Intensive Wildife Management alternative would have the largest regional effect on grazing during 1978-85 with the No Grazing alternative having the largest effect from 1986-2000. Range livestock earnings for the region averaged $\$ 50.8$ million/year for 1970-75. The reduction in income related to the Intensive Wildlife Management alternative would be about 1 percent of this amount for 1978-85. The Proposed Action alternative would reduce regional income by 0.5 percent. A total 


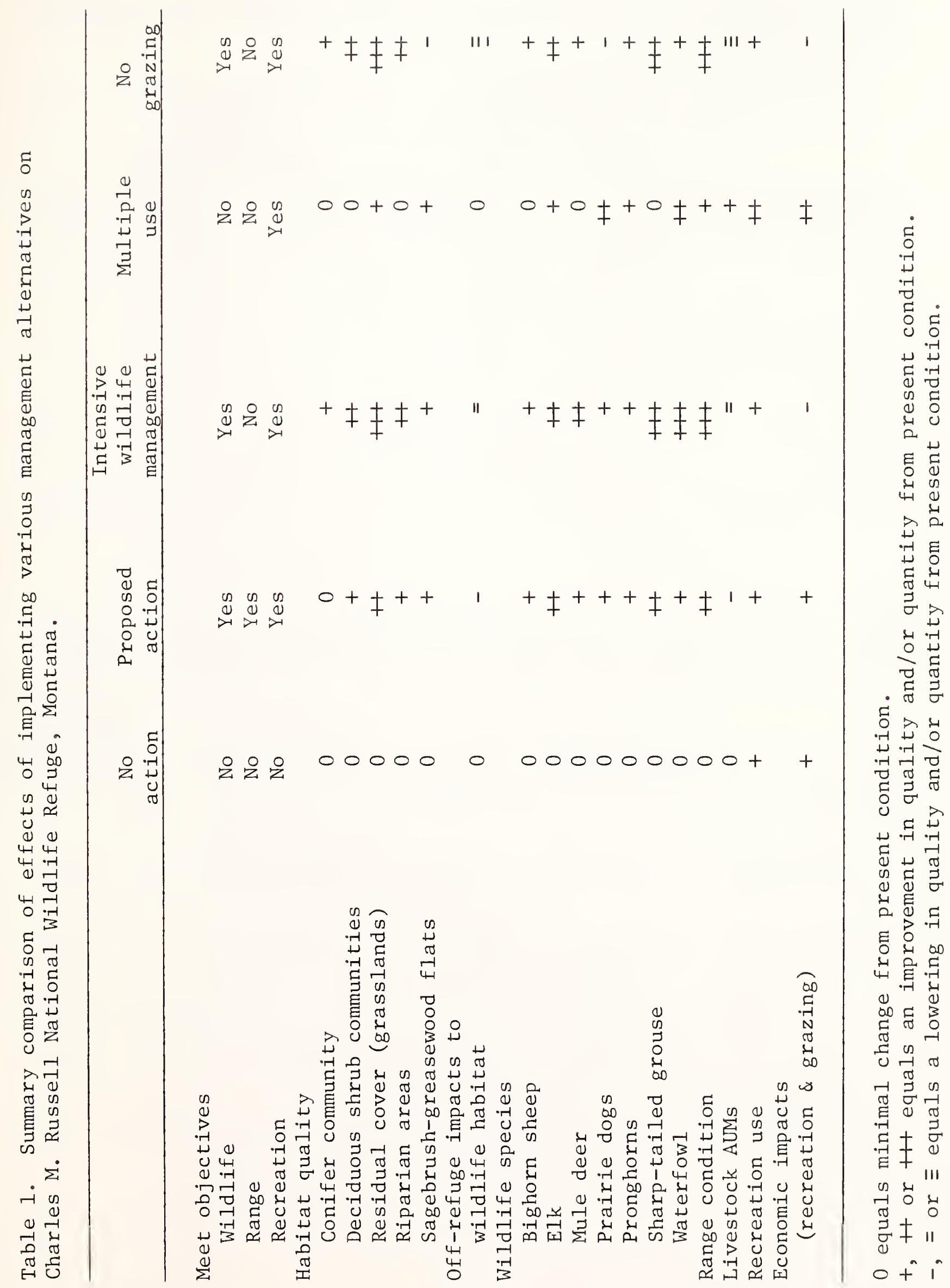


Table 2. Comparison of regional income and employment from recreation for five management alternatives for Charles M. Russell National Wildlife Refuge, Montana.

\begin{tabular}{|c|c|c|c|c|c|c|}
\hline Alternative & $\begin{array}{r}\text { Incre } \\
\text { income }\end{array}$ & $\begin{array}{l}\text { in } \\
\left(000^{\prime} \mathrm{s}\right) \\
1986- \\
2000\end{array}$ & Totals & $\begin{array}{l}\text { Increas } \\
\text { employn } \\
\text { (man-y } \\
1978-85\end{array}$ & $\begin{array}{l}\text { in } \\
\text { nt } \\
\text { rs) } \\
1986- \\
2000 \\
\end{array}$ & Totals \\
\hline No action & $\$ 153.9$ & $\$ 117.7$ & $\$ 271.6$ & 21.0 & 15.5 & 36.5 \\
\hline Proposed action & 162.5 & 129.9 & 292.4 & 22.5 & 16.0 & 38.5 \\
\hline $\begin{array}{l}\text { Intensive wildlife } \\
\text { management }\end{array}$ & 123.9 & 40.5 & 164.4 & 16.5 & 3.5 & 20.0 \\
\hline Multiple use & 197.5 & 204.5 & 402.0 & 28.0 & 24.0 & 52.0 \\
\hline No grazing & 168.8 & 132.5 & 301.3 & 22.5 & 16.0 & 38.5 \\
\hline
\end{tabular}

Table 3. Comparison of regional effects from grazing for five management alternatives for Charles M. Russell National Wildlife Refuge, Montana.

\begin{tabular}{|c|c|c|c|c|}
\hline Alternative & $\begin{array}{c}\text { Changes in AUMs } \\
(1978-2000)\end{array}$ & $\begin{array}{c}\% \\
\text { Change } \\
\end{array}$ & $\begin{array}{c}\text { Changes in income } \\
(1978-2000)\end{array}$ & $\begin{array}{l}\text { Changes in } \\
\text { employment } \\
\text { by man-years } \\
(1978-2000)\end{array}$ \\
\hline No action & 0 & 0 & 0 & 0 \\
\hline Proposed action & $-19,479$ & $-32 \cdot 4$ & $\$-257,000$ & -23 \\
\hline $\begin{array}{l}\text { Intensive wildl } \\
\text { management }\end{array}$ & Iife $\quad-33,275$ & -55.4 & $-473,000$ & -42 \\
\hline Multiple use & +1152 & +2.0 & +3000 & +1 \\
\hline No grazing & $-60,108$ & -100.0 & $-852,000$ & -76 \\
\hline Existing $\mathrm{c}$ & condition: $\quad 60,108$ & AUMs & & \\
\hline
\end{tabular}


of about 6,050,860 AUMs are required to sustain the livestock base in the region. This figure is based on the number of sheep and cattle in the region during 1970-75. The AUM reductions under the Proposed Action alternative would, for $1978-85$, be about 0.3 percent of the total AUMs in the region. The No Grazing, Intensive Wildlife Management and Multiple Use alternatives would affect regional AUMs by $0.5,0.6$ and 0.1 percent, respectively. The No Action alternative would have no effect on grazing in the region.

These figures indicate that regional economic effects due to grazing changes on CMR would be insignificant under any of the alternatives. Primarily, effects of grazing changes would be felt by permittees who use refuge lands. 


\section{AFFECTED ENVIRONMENT}

\section{OVERVIEW}

The Missouri River has long served as an access route to Montana and the West. Although the river still receives limited use for transportation, it is primarily a recreational waterway. The "breaks," erosional interruptions in the river's escarpment, once supported primitive man and a diversity of animals. Today man is still on the scene but many wildlife species, including plains grizzlies, bison, Audubon bighorn sheep and wolves have vanished from the breaks.

CMR embraces 1,094,301 acres of land and water and stretches 125 miles from the Fort Peck Dam west along the reservoir and Missouri River in northeastern Montana (Table 4). Private individuals own about 50,000 acres and the State of Montana owns about 35,000 acres within the CMR boundary. These inholdings are scattered and vary in size from 40 to almost 5000 acres.

Table 4. Land and water acreages within the Charles M. Russell National Wildife Refuge, Montana.

\begin{tabular}{lcc}
\hline & Area & Acres \\
\hline Fort Peck Reservoir (at maximum operating pool) & 249,000 \\
Federal lands & 760,000 \\
State lands & 35,645 \\
Private lands & 49,656 \\
$\quad$ Total land and water acres & $1,094,301$ \\
\hline
\end{tabular}

The area now known as CMR was originally withdrawn from the public domain by President Franklin D. Roosevelt under Executive Order 7509 in 1936; initially it was called the Fort Peck Game Range. As outlined in the Executive Order, the primary purpose of the range was:

"...for the conservation and development of natural wildlife resources and for the protection and improvement of public grazing lands and natural forage resources...natural forage resources therein shall be first utilized for the purpose of sustaining in a healthy condition a maximum of four hundred thousand $(400,000)$ sharptail grouse, and one thousand five hundred $(1,500)$ antelope, the primary species and such nonpredatory secondary species in such numbers as may be necessary to maintain a balanced wildlife population...Provided further, that all the forage resources within this range or preserve shall be available, except 
as herein otherwise provided with respect to wildlife, for domestic livestock..."

In 1963 the Fort Peck Game Range was redesignated the Charles M. Russel1 National Wildlife Range by Public Land Order 2951, in honor of Montana's great cowboy artist. With renaming of the area, the Secretary of Interior reaffirmed the primary purpose and mission of CMR as a unit of the National Wildlife Refuge System, with primary responsibilities for administration of the area resting with FWS. BLM, however, continued to administer the livestock grazing program, subject to the program and policy requirements of FWS. On 27 February 1976 the administrative status of CMR and all other game ranges in the nation was again changed by the signing of Public Law 94-223. This brought to a close the joint management between BLM and FWS. Public Land Order 5635 (1978) changed the name of the game range to Charles M. Russell National Wildlife Refuge (Table 5).

Table 5. Major documents affecting the Charles M. Russell National Wildlife Refuge, Montana.

\begin{tabular}{|c|c|c|c|c|}
\hline Document nai & ame & No. & Date & Subject \\
\hline Executive 0 & Order & 6491 & $12 / 12 / 33$ & Ft Peck Dam (COE) \\
\hline$"$ & $"$ & 6707 & $05 / 09 / 34$ & $" \quad " 11$ \\
\hline$"$ & $"$ & 6841 & $11 / 09 / 34$ & 1111 \\
\hline$"$ & $"$ & 7331 & $04 / 03 / 36$ & $" 11$ \\
\hline$"$ & $"$ & 7509 & $12 / 11 / 36$ & Ft Peck Game Range \\
\hline$"$ & $"$ & 9132 & $04 / 13 / 42$ & Ft Peck Dam (COE) \\
\hline Secretarial & 1 Order & 2843 & $11 / 17 / 59$ & Transfer jurisdiction \\
\hline Public Land & d Order & 2951 & $02 / 25 / 63$ & Name change (FWS) \\
\hline$" 1$ & $"$ & 4588 & $03 / 25 / 69$ & $\begin{array}{l}\text { UL Bend National Wild- } \\
\text { life Refuge (FWS) }\end{array}$ \\
\hline Public Law & & $94-223$ & $02 / 27 / 76$ & $\begin{array}{l}\text { FWS sole administrator } \\
\text { of the Wildlife Range }\end{array}$ \\
\hline Public Land & d Order & 5635 & $04 / 25 / 78$ & $\begin{array}{l}\text { Name change to Refuge } \\
\text { (FWS) }\end{array}$ \\
\hline
\end{tabular}


Although Public Law 94-223 vested management authority of CMR with FWS, BLM still retains management authority over the Upper Missouri National Wild and Scenic River, part of which flows through CMR, as provided by Public Law 94-486.

Conflicting legislation and mandates exist between FWS and COE. A memorandum of agreement has been signed by both agencies and is guiding current management of the area. About 8190 acres are occupied by supporting facilities such as powerhouses, dam, townsite and maintenance areas. Special public use areas have been identified by COE for development of water-based recreation at 16 locations. Three areas are presently leased by MDFW\&P as state parks. The Water and Power Resources Service, formerly the Bureau of Reclamation, is-responsible for power distribution.

Among other agency-management authorities on CMR is MDFW\&P. The department, together with FWS, manages resident game and fish. State school lands within CMR, generally located in sections 16 and 36, are administered by MDSL. Status of these lands is similar in many respects to that of private inholdings.

Construction and maintenance facilities for US Highway 191 on the west side of CMR and State Highway 24 near Fort Peck on the east are administered by the Montana State Highway Department. Certain aspects of livestock grazing within CMR, such as the control of disease outbreaks and branding of cattle, are managed by the Montana Livestock Board.

The special mission of the National Wildlife Refuge System of which CMR is a part is to provide, manage and safeguard a national network of lands and waters sufficient in size, diversity and location to make available now and in the future public benefits associated with wildlife over which the federal government has responsibility, particularly migratory birds and endangered species (Fish and Wildlife Service 1979).

The broad objectives of the National Wildlife Refuge System are to:

1) Preserve, restore and enhance in their natural ecosystems all species of animals and plants that are endangered or threatened with becoming endangered on lands of the National Wildlife Refuge System.

2) Perpetuate the migratory bird resource for the benefit of people.

3) Preserve the natural diversity and abundance of mammals and nonmigratory birds on refuge lands.

4) Provide understanding and appreciation of fish and wildlife ecology and man's role in his environment and to provide visitors at service installations with high quality, safe, wholesome and enjoyable recreational experiences oriented toward wildlife.

\section{CLIMATE}

The climate of the CMR region is typical of the high plains in North America with bitterly cold winters $\left(-34^{\circ} \mathrm{F}\right.$ to $\left.-50^{\circ} \mathrm{F}\right)$ and hot summers $\left(100^{\circ} \mathrm{F}+\right)$. Recorded extremes are $-58^{\circ} \mathrm{F}$ and $112^{\circ} \mathrm{F}$. Low humidity, high temperatures and moderate to strong winds cause rapid loss of soil 
moisture. Mean annual precipitation is $12-13$ inches with about 70 percent occurring from April-September. Due to the dominantly heavytextured soils, runoff is rapid, often exceeding 50 percent of the total precipitation. The average frost-free period is about 120 days. CMR is also subject to intense lightning storms from late July-early September, often resulting in wildfires.

\section{GEOLOGY}

The Missouri and Musselshell rivers flow through deep valleys with narrow flood plains lying 500-1000 feet below the average elevation of surrounding uplands. Elevations vary from slightly over 2000 feet above mean sea level (msl) near Fort Peck Dam to over 3200 feet in the Seven Blackfoot area. Three main landforms, uplands, breaks and flood plains, dominate CMR and the surrounding area. Uplands are level-to-rolling prairies dissected by intermittent streams flowing toward the Missouri River in a generally eastward direction. These are the sagebrushgrassland plains typical of eastern Montana.

The breaks lying adjacent to the Missouri River are typified by dissected, rough terrain often culminating in spectacular badlands. This topography is common to a strip of land 2-10 miles wide along the Missouri River and varies from low, barren hills of the Big Dry area south of Fort Peck to severely eroded coulees of the Seven Blackfoot and Burnt Lodge areas and the juniper, pine and grassland ridges on the western half of CMR. Approximately 40-50 percent of lands within CMR consist of steep ridges and eroded coulees.

Flood plains occur along the Missouri and Musselshell rivers at upper extremities of Fort Peck Reservoir and along some of the larger drainages. These developed from pre-glacial river and stream alluvium and are characterized by heavy clay soils, deciduous trees, sagebrush and grassland. These flood plains are comparatively flat and vary in width from 25 yards-2 miles.

The Judith River formation outcrops west of Rock Creek in Phillips County in major stream valleys. It is composed of several hundred feet of interbedded shale, siltstone and sandstone with scattered beds of lignite and bentonite. This formation has good stability but its outcrop area is limited to steep slopes.

Bearpaw shale underlies more of CMR than any other formation. The breaks west of UL Bend are almost entirely composed of this shale as are lower slopes east of UL Bend, except in the central and southern parts of Big Dry Arm. Bearpaw shale is almost entirely composed of dark gray, clayey shale and includes thin beds of bentonite. The predominant particle size of this formation is clay and the predominant clay mineral found in Bearpaw shale is montmorillonite. As a result, this unit swells when exposed in steep slopes and erodes rapidly at many locations.

Fox Hills sandstone is composed of yellowish gray sandy shale, claystone, siltstone and/or very fine-grain sandstone and grades upward into relatively thick beds of resistant fine and medium-grain yellowish brown sandstone. The formation is generally found in areas of high 
relief along Fort Peck Reservoir such as Larb Hills, Harper Ridge and much of Garfield County. Along Big Dry Arm, Fox Hills sandstone is found south to Rock Creek (east).

The Hell Creek formation is generally found above 2500 feet in elevation in the central and eastern parts of CMR. The formation is composed of unconsolidated fine sediments such as claystone, shale, siltstone and sandstone. Some of the clay and silt-rich zones of the formation tend to shrink and swell during excavation or when exposed to water.

Fort Union formation is found in Garfield and McCone counties, east and west of Big Dry Arm and south of Rock Creek (east). The formation is also found in the highest parts of Larb Hills. Tullock member, most widely found subunit of the Fort Union formation on CMR, is light gray to dark gray shale alternating with sandy shale and gray to buff sandstones. Lignite beds are also found in association with this member. This formation responds similarly to the Hell Creek formation to most development activities.

Glacial till is found at scattered locations, particularly between Rock Creek (west), Phillips County and Valentine Creek. This is dense, clayey material with characteristics similar to Bearpaw shale. Outwash and related deposits are found west of UL Bend on low benches and in the Missouri valley, in the lee of bedrock ridges. These latter deposits are porous and stable.

The historical rock record exposed on CMR dates to almost 80 million years bp (before present) or Late Cretaceous. Sedimentation dominated the area until about 58 million years bp. For the next 55 million years, sediments were successively eroded away as the plains and surrounding areas were sporadically uplifted. In the past 3 million years, glaciers advanced over the area, the most recent retreating northward about 20,000 years bp. Construction of Fort Peck Dam in 1937 further altered CMR's landscape.

Ice jams cause the highest levels of flooding on major streams such as the Missouri River, Big Dry Creek and Musselshel1 River. Snowmelt runoff causes the greatest flood flow volumes on these same streams. High flows can occur on these streams any time from January-August. Rainstorms cause major flooding on smaller drainages.

All stream channels flowing through unconsolidated material meander over time. The Missouri River upstream of Fort Peck Reservoir has shifted as much as 2000 feet in about 65 years at average rates up to 30 feet/year. The Fort Peck Reservoir delta is the area of greatest channel change and sedimentation; other areas of channel change and bank erosion are found on most upstream portions of most stream bottoms.

Areas of current and past landslide activity cover about one-third of the surface area of CMR. Steeply sloping areas in the western Bearpaw breaks, Garfield County, Larb Hills and Harper Ridge have the most significant number of landslides. Landslides are of several types; slump-earthflows are the most common. Rapidly moving debris flows also occur, especially in the western Bearpaw breaks.

Piping is an important erosional process in the Hell Creek formation and in landslide deposits. Pipes may collapse or create general 
ground instability. Areas of classic piping on CMR occur at Hell Creek, Big Dry Arm and other locations.

Results of a mineral survey of CMR (Geological Survey 1979) indicate that parts of the area have a moderate potential for oil and gas, low to moderate potential for lightweight aggregate, bentonite and coal and low to nil potential for other mineral commodities such as uranium or gold. Oil accumulations probably lie at depths greater than 4000 feet. The most likely area of accumulation underlies the western part of CMR.

There is a good possibility that the entire refuge is underlain by shallow natural gas deposits. Significant resources of this type are already being developed in the Bowdoin field and on flanks of the Bearpaw Mountains. The gas deposits, if present, would occur at depths of less than 2000 feet.

Bentonite resources are estimated at about 4.3 billion tons. Highest quality bentonite beds are found in Bearpaw shale, particularly west of Nichols Coulee in the Siparyann bed. This bed ranges in thickness from 1-6 feet at the outcrop. Bentonite resources east of Nichols Coulee are considered of low potential because of thinness and poor quality. Bentonite on CMR is of unacceptable quality as drilling mud but acceptable for the casting industry to bind molding sand and possibly by the taconite industry to bind finely ground iron ore into pellets.

Bearpaw shale has a moderate potential for use as lightweight aggregate. Shale sequences high in bentonite content are the most suitable. The refuge contains significant quantities of sand and gravel; one gravel pit is currently in use near Hell Creek.

CMR is estimated to contain over 290 million short tons of coal. of this total, the Judith River formation may contain about 190 million short tons in beds averaging less than 2.5 feet in thickness and which contain about 40 percent ash. About 100 million short tons of coal are found in Hell Creek and Fort Union formations in beds ranging from 1-5 feet in thickness.

\section{SOILS-WATER RESOURCES}

Four major soils orders are represented on the refuge. They are Entisols (soils characterized by very limited development), Aridisols (well-developed soils formed in a dry environment), Mollisols (soils with surface layers (horizons) noticeably darkened by organic matter accumulations) and Vertisols (soils that have a self-plowing action because of high shrink-swell rates associated with varying moisture levels).

Mollisols are prairie soils generally found in areas of higher rainfall than found on the refuge; their extent is very limited here.

Aridisols present on CMR are composed of two types or suborders: those characterized by salt and clay accumulations below the surface, resulting in a relatively impervious subsoil and those with no significant salt or clay accumulations. These latter types represent the most significant agricultural potential of any soils present because of their fertility and areal extent. They are found on the more gentle 
slopes of CMR. Garfield and McCone counties most typically contain these soils, which are generally derived from sandstone or alluvium in sedimentary uplands.

Entisols are typically found on the breaks portion of CMR. The vegetated surface is quite unstable on these steeply sloping breaks and soils are poorly developed. Other Entisols include those present on flood plains of rivers and major creeks in the area. Parent materials (unconsolidated minerals or organic matter from which soils are derived) for these Entisols include alluvial deposits laid down by streams or sedimentary deposits (siltstone, sandstone or clay from Bearpaw shale).

Vertisols are most commonly associated with the very fine-textured Bearpaw shales and are generally located north of the Missouri River. They are typically found on strongly sloping sedimentary (Bearpaw shale) uplands or as fans or terraces formed below the Bearpaw shale.

In addition to topographic features which affect soils, as described previously, geologic formations such as Bearpaw shales or glacially derived deposits have a definite effect on soils and soil-forming processes. Bearpaw shales and glacial till deposits occur mainly north of the Missouri River on the east side of the Musselshell River and on both sides of the Missouri to the west of the Musselshell River. Soils in Garfield and McCone counties are more commonly derived from sandstone deposits or are formed as alluvial deposits from sedimentary uplands.

Concerning limitations of those soils present, Aridisols and Mollisols are generally amenable to cultivation and respond well to good management practices. Vertisols and Entisols are generally unsuited to agriculture because of their salt content, low productivity and topographic features which are generally accompanied by high erosion hazards. Several thousand acres of depauperate, heavy clay or salt-affected soils exist on CMR. These soils have low water infiltration rates. Precipitation on such sites remains on the surface until it evaporates. The soil may be completely dry at depths of 6-8 inches below the surface. Range sites associated with such soils are referred to as dense clays or panspots.

Soils or land forms present in Class VIII capability (Appendix 7) are considered suitable only for recreation, wildlife or watershed uses. Many of these mapping units represent parent materials rather than soils. Decomposing sandstone outcrops, Bearpaw shale, beach sand and badlands are included in this category.

Soils and weathered bedrock on CMR tend to be moderately to highly expansive. Not only do these soils swell when wetted but they also heave when excavations are made.

According to Schmidt (1979) erosion rates on the refuge are high. Stock ponds have an average life of about 10 years. The range for sediment accumulation in stock ponds in Bearpaw shale drainages (Willow Creek) is presently from 0.1-5.3 acre-feet/mi2/year. Schmidt stated that yields in other steeply sloping Bearpaw breaks may be as high as 10 acre-feet/mi2/year. The larger figures are as high as those measured anywhere in the semi-arid West. He indicated that the distinction between natural (geologic) erosion and accelerated (man-caused) erosion is not clear. He did state that the occurrence of trenched valley fills 
extending into headwaters, however, presents the likelihood that erosion rates were much less in previous times, perhaps prior to large scale grazing in the late $1800^{\prime}$ 's.

Schmidt stated that estimates of bare ground percentages correlate more closely with erosion intensity than any other factor identified in the literature. Estimates of 340 samples on the refuge revealed average ranges of from 15-42 percent bare ground for the potentially best range sites.

Since many of the access roads on the refuge are built on gumbolike Bearpaw shale, any measurable precipitation, together with motorized use of these roads, is enough to turn them into impassable quagmires. Ruts created by vehicles during wet weather often do not heal from one year to the next. These ruts then provide channels for water runoff during subsequent rainfall, often leading to complete deterioration of the road and ultimately necessitating complete regrading of the road system.

The most conspicuous water areas on CMR are Fort Peck Reservoir and the Missouri River. The reservoir and river occupy approximately 249,000 acres, over 18 million acre-feet of water, when the reservoir is at peak storage capacity, maximum pool level of 2250 feet above msl. CMR embraces 35 miles of free-flowing Missouri River upstream of the Fort Peck Dam and only one mile below it. The reservoir extends approximately 90 miles from east to west. Sediment loads in all streams are high as a result of the extremely erosive soils on CMR.

Ground water is relatively deep in the breaks area and domestic wells generally vary from 300-1200 feet in depth (Table 6). Artesian wells can be developed over much of CMR by drilling to the Judith River formation. Best quality water is found in wells drilled in the alluvium along the Missouri River valley. Good quality water can also be found in the Fox Hills-Hell Creek aquifer in Garfield and McCone counties and on Harper Ridge where springs are numerous.

Table 6. Groundwater sources on Charles M. Russell National Wildlife Refuge, Montana.

\section{Source}

Judith River formation

Bearpaw shale

Fox Hills sandstone

He11 Creek formation

Fort Union formation

Glacial deposits

Alluvium
Water development potential

Very good

None

Good in upper part where topography not greatly dissected.

Good in lower part where topography not greatly dissected.

Poor

Poor

Fair-good 
Annual runoff for CMR is estimated to range from 0.02-0.04 cubic feet/second (cfs)/ $\mathrm{mi}^{2} /$ year or 14-29 acre-feet/mi $2 /$ year. Average discharge of the Missouri River is $9288 \mathrm{cfs} /$ year or $0.23 \mathrm{cfs} / \mathrm{mi}^{2} /$ year. However, average discharge is experienced only about 13 percent of the time. Flows as low as 0.5 times the mean annual flow occur about 3 percent of the time and flows as great as 1.5 times the mean annual flow occur about 7 percent of the time (Bureau of Land Management 1979).

Past livestock management practices have resulted in development of small stock ponds and wells within CMR. These stock ponds are normally less than 1 acre in size and are located near heads of small coulees. As discussed earlier, most ponds fill with silt and a few dams occasionally fail during heavy runoff.

\section{WILDLIFE HABITAT-RANGE RESOURCES}

Wildlife habitat was evaluated for representative species during summer 1978 on five major vegetative types (Appendix 2). The largest type is the sagebrush-greasewood-grassland, which occupies 61.4 percent of the area and includes four subtypes: big sage-grasslands, silver sage-bottomlands-sandy uplands, greasewood-grasslands-bottomlands and shadscale-barren areas (Fig. 2). Big sagebrush and greasewood are the predominant shrubs with species such as shadscale, silver sage, rubber rabbitbrush and skunkbrush also present. Important grasses are western wheatgrass, needle and thread, green needlegrass, bluegrama, Junegrass, Sandberg bluegrass, plains muhly and bluebunch wheatgrass. The condition of big sagebrush and associated shrub and grass species is limiting to all wildlife species sampled in this type (Appendix 2).

The ponderosa pine-juniper type occurs on 35.5 percent of CMR and includes three subtypes: ponderosa pine, Douglas fir and juniper. Four coniferous tree species are indigenous: ponderosa pine, Douglas fir, limber pine and Rocky Mountain juniper. Forest communities are found on some of the poorer soils. Trees are apparently prevented from occupying better sites by competition with grasses for low soil moisture (Prodgers 1979).

Other major types are grassland-deciduous shrub, riparian-deciduous riverbottoms (including ash coulees) and cultivated lands (hayland and dryland).

Trees, shrubs and grasses are inadequate for various wildlife requirements sampled. Security cover for elk is lacking from Timber Creek to Fort Peck (Campbell 1979). The interaction of gentle topography, roads and sparse conifer cover creates security cover problems. Mule deer require better interspersion of trees, sage and grasses as well as more suitable shrubs (big sagebrush, skunkbrush, chokecherry, snowberry, rose, serviceberry and rubber rabbitbrush) and forbs for food. Sharptailed grouse need 2-3 inches more residual cover (8-10 total) and better developed shrub communities (buffaloberry, chokecherry, rose and snowberry) for food and cover. Mountain bluebirds require more nesting cavities. Porcupines need denser ground cover and more denning sites.

The grassland-deciduous shrub community is found in limited areas and comprises only 1.8 percent of the land base. It includes shrub communities of high importance to wildlife, especially sharp-tailed 
CHARLES M. RUSSELL

NATIONAL WILDLIFE REFUGE

ENVIRONMENTAL STATEMENT

VEgetATION TYPES

FonOEROSA PINE. JUNPER

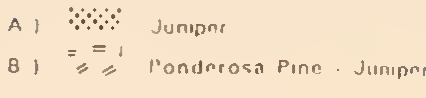

SAGE - GiakASEWOND - GAASSLAND

VEGETATION TYPES

(A) $(B)$ Sage Grasslants

Decidunus Shrub Grasslants
Aiver Boulos

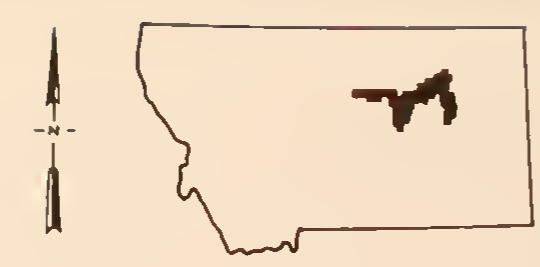

FIG. 2 VEGETATION TYPES

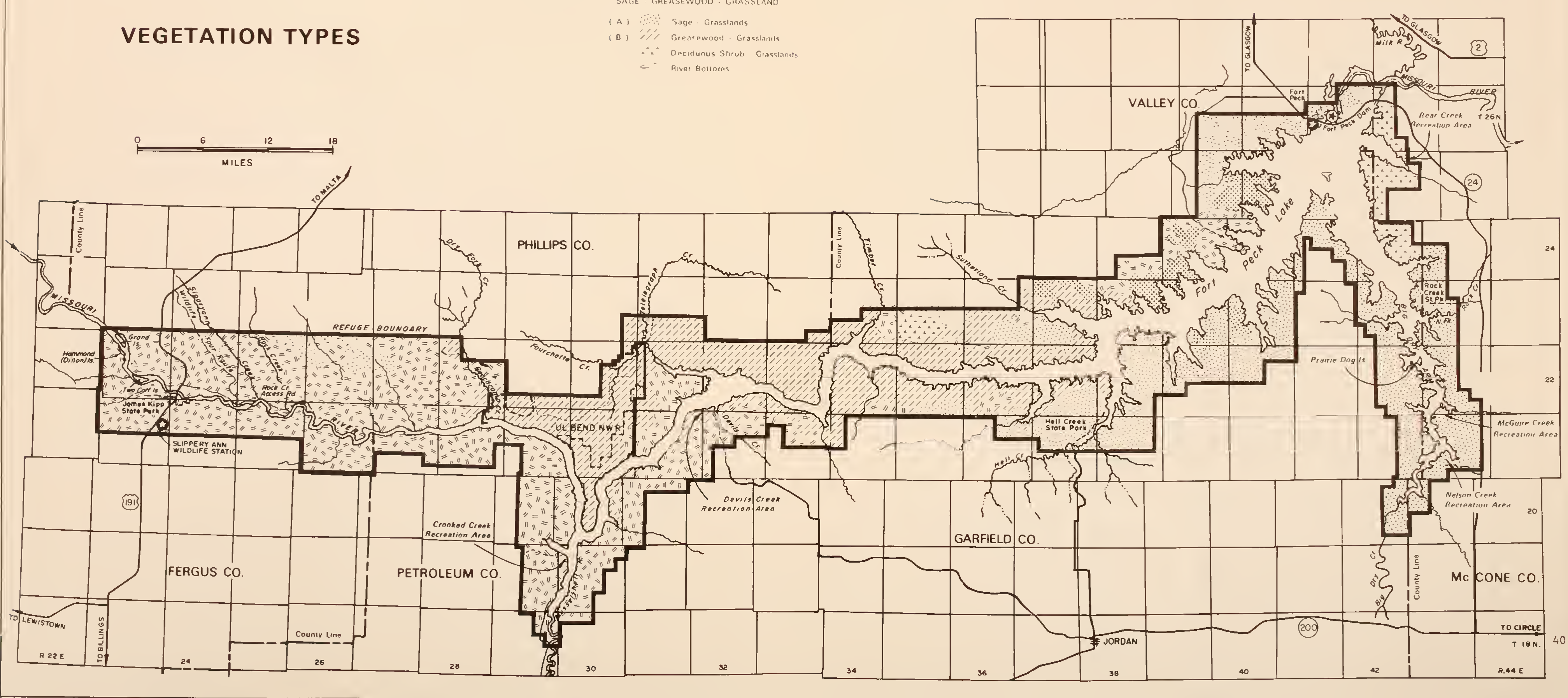



grouse. In those areas where grassland predominates, the key species are perennial grasses such as bluebunch wheatgrass, western wheatgrass and green needlegrass. Prairie forbs include sagewort, wild licorice, sunflower, dandelion, yellow sweet clover, vetch, phlox and prairie thermopsis plus many others. Arkansas rose, common snowberry, chokecherry, western serviceberry and buffaloberry are important shrub components of this type. Shrub parameters are better in this type than in any other type but are still inadequate for wildlife (Appendix 2).

The riparian community comprises only 0.7 percent of the area. The major portion of this most productive and important wildlife habitat on CMR was permanently destroyed when Fort Peck Reservoir was filled in the 1940 's. Approximately 35 miles of free-flowing river and associated habitat still remain on the western portion. However, due to the gradual silting at headwaters of the reservoir, this reach is subject to flooding and numerous ice jams. This flooding causes a change in wildlife habitat and associated wildife-related recreation opportunities.

Woody plants in the riparian community include four species of cottonwood, four species of willow, green ash, box elder and several shrubs also found in the grassland-deciduous shrub type. There are also several small stands of quaking aspen in this type.

Cultivated lands make up 0.6 percent of the area and occur primarily in the river bottoms. On the east half of the refuge cultivated lands are often found on upland sites. Cultivated lands are a mixture of small grains (barley and wheat), alfalfa and wild hay. Cultivated lands are considered a major type in this analysis.

Wildlife habitat in riparian and cultivated types rated higher than all other types. Habitat quality for white-tailed deer in these areas rated low because browse was limited on minor continuous streams across the refuge.

A variety of other small habitats is represented within and adjacent to the major vegetative areas. Some of these are canyons, bluffs or rock outcrops and ponds, all of which sustain or contribute to a variety of plant and animal communities. Pond development is not extensive and the ponds present are in poor condition for wildlife due to lack of emergent vegetation and inferior upland vegetation.

A range survey was conducted on the refuge in 1978 (Fish and wildlife Service 1979) in accordance with the Soil Conservation Service (SCS) National Range Handbook. Range sites were identified on the basis of soil mapping units, precipitation and geology (Appendix 8). Most common sites included overflow, sandy, silty, clayey, thin hilly, shallow clay, panspots, dense clay, thin breaks, saline upland, shale and badlands. The less common sites included saline lowlands, sands, shallow-to-grave1, shallow and very shallow. The methodology used in the survey is described in Appendix 8.

After a range site was identified the plant species present were compared with the range site guide criteria for the site at climax to obtain range condition. Range condition is the amount of deviation from the natural potential or climax. Range condition categories are poor (0-25 percent of climax), fair (26-50 percent of climax), good (51-75 percent of climax) and excellent (76-100 percent of climax). 
Overall results of range conditions found on grazing allotments subjected to livestock grazing are excellent, 18 percent; good, 74 percent; fair, 7 percent; and poor, 1 percent (Appendix 9).

General observations reveal that range conditions for unallotted portions of CMR (no livestock) are predominantly excellent and areas inaccessible to livestock by reason of topography or remoteness from water are excellent. Areas in fair or good condition are considerably more accessible to livestock. Poor range conditions are typically associated with prairie dog towns; locations of prairie dog towns have high correlations with past disturbances such as corrals, stock ponds, overgrazed areas or former homesteads and are probably indicators of past use rather than causes of current conditions (C. Knowles personal communication).

On CMR, 10 permittees graze 48 percent of the total active federal AUMs and 48 permittees graze 400 AUMs or less (Appendix 10). Fifteen of the 87 operators are dependent on refuge lands for more than 30 percent of their annual AUM requirements and 10 operators fulfill 20-30 percent of their annual needs from refuge lands. The remaining 62 operators derive less than 20 percent of their annual forage requirements from CMR.

One of the problems identified during the planning process has been the season of livestock grazing use allowed on the refuge. In the past, grazing seasons have been established more to reflect the needs of operators than to protect natural resources. Currently, six allotments use rest-rotation systems, three use deferred rotation systems, 15 have authorized use which encompasses year-long grazing on a portion or all of the allotment and 43 allotments have either seasonal or continuous grazing (generally spring through fall). Livestock allotment boundaries are generally fenced on east and west boundaries or have physical barriers which preclude livestock movements between allotments. Allotment boundaries generally extend north or south off the refuge. The typical situation is that adjoining lands off the refuge are included in common allotments with CMR lands with no boundary fence separating them.

\section{WILDLIFE}

At least 45 mammalian species inhabit CMR, ranging from shrews to Rocky Mountain elk and bison. However, the only bison maintained are in exhibition pastures at Lewistown and Fort Peck; a few stray onto the refuge from private ranches in Fergus and Garfield counties.

Mule deer exceed all other ungulate wildlife in number and distribution (Fig. 3). In this area they are nonmigratory, using the same range the entire year although some local movement occurs with seasonal changes in food and range use habits. In the early 1970's mule deer populations dropped dramatically from 10-11 deer to 2-3 deer $/ \mathrm{mi}^{2}$ (Mackie 1976) and then stabilized; they now appear to be increasing to 5-6 deer $/ \mathrm{mi}^{2}$ (Montana Department of Fish, Wildlife and Parks 1979).

Deciduous river bottoms of the Missouri and Musselshell rivers which have not been inundated by Fort Peck Reservoir are inhabited by white-tailed deer (Fig. 3). Small numbers of white-tailed deer also 
UNITED STATES DEPARTMENT OF THE INTERIOR

FISH AND WILDLIFE SERVICE

CHARLES M. RUSSELL

NATIONAL WILDLIFE REFUGE

ENVIRONMENTAL STATEMENT

MuLE DEER HABITAT

LEGEND

MULE DEER

AND

WHITE-TAILED DEER HABITAT

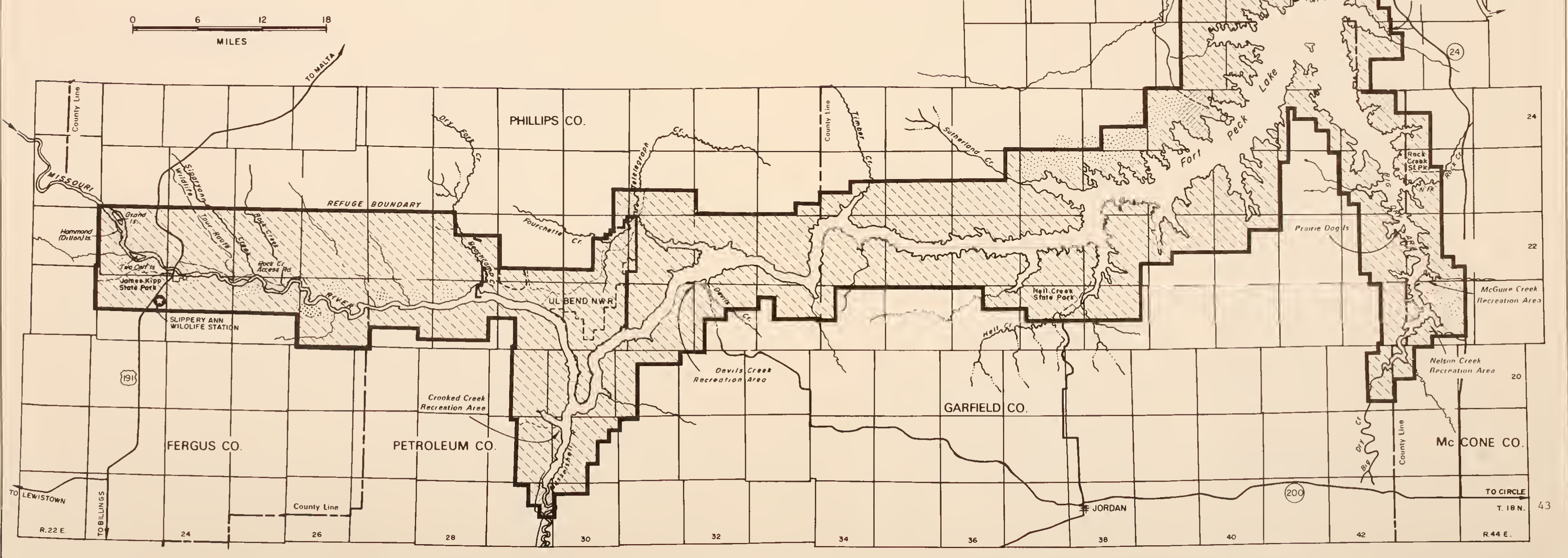



occur along the reservoir near the Pines Recreation Area and the Fourchette-Telegraph Creek area.

The last native elk vanished from the breaks around the turn of the century. Eighty-one elk were successfully reintroduced in 1951 at three locations in Valley and Fergus counties. Another $49 \mathrm{elk}$ were released at two locations in Phillips County a year later. Most are now found on the north side of the refuge in the breaks (Fig. 4); however, some expansion of their range to areas south of the Missouri River in Fergus, Petroleum and a portion of Garfield counties has occurred. Further expansion in these areas may add an additional 700-900 animals to the herd. Adjacent landowners' and grazing permittees' attitudes are negative toward this expansion and poaching and illegal shooting could limit further extension of their range. Crop depredations from elk occur on private land both within and adjacent to CMR in the northeast. The present elk population level in the breaks ecosystem (on and off the refuge) is at the level (approximately 1300-1500) that can be tolerated by the ranching community. It is important to recognize that CMR composes only a portion of the herd's habitat. Elk do not recognize the refuge boundary and freely use habitat on either side.

Pronghorns occur sparingly within CMR since there is little suitable year-round habitat. However, during severe winter storms, pronghorns and mule deer move into the breaks for food and shelter. Concentration areas for the severe winters of 1977-78 are shown on Fig. 5.

Sixteen Rocky Mountain bighorn sheep were released in 1947 along Billy Creek within a 328-acre fenced enclosure on range formerly occupied by Audubon bighorn sheep. In 1951 the herd had grown to 54. In 1952 the fence was removed, the animals dispersed, and by 1963 the entire population had disappeared, apparently because of poaching, predation, disease and competition with livestock. A second attempt to reestablish bighorns in the breaks was undertaken between 1958-61.

Forty-three sheep were stocked in a 2200-acre exclosure near the west boundary of CMR (Fig. 6). The population climbed to 80-100 animals by 1969. Then a series of circumstances, including severe winters and competition with livestock, decimated the population until only 10-15 animals remain today.

Black-tailed prairie dogs have been eliminated over much of their original range in the western US. However, 112 widely scattered dog towns (Fig. 7) occupying approximately 6600 acres are present on CMR. These towns provide all or partial habitat requirements for some 30 other species of wildife.

The rugged breaks, benchlands and flood plains combine to support a large variety of other mammals including bobcats, badgers, coyotes, striped skunks, white-tailed jackrabbits, mountain and desert cottontails, raccoons, porcupines and numerous small rodent species. Beaver, mink and muskrats occur along the river bottoms and, to a lesser degree, along the reservoir shoreline.

The diverse, avian habitat on the refuge attracts a large variety of birds. Over 245 species have been recorded, of which 15 percent are year-round residents. Upland sandpipers, mountain plovers, long-billed curlews and burrowing owls are among the more unique birds which inhabit 
the grassy benchlands; burrowing owls and mountain plovers are also commonly associated with prairie dog towns.

Cottonwood trees partly inundated by the reservoir support nests of several pairs of osprey as well as rookeries of double-crested cormorants and great blue herons. Prairie falcons and golden eagles are common nesting residents on cliffs of the more rugged and inaccessible portions of the breaks. Two of the prairie falcon nest sites appear to be suitable for cross-fostering of peregrine falcons.

Very little waterfowl production occurs on Fort Peck Reservoir; however, geese concentrate in the safety of several of the bays during their molting period and small flocks of ducks over-winter below the dam most years. The largest numbers and varieties of waterfowl occur during fall migration when the birds utilize standing grain crops and marsh developments along the flood plain for feeding and staging. Limited waterfowl production occurs on upland ponds.

The most common upland game birds are sharp-tailed grouse. They occur across CMR in the ecotone between forest and prairie, with woody vegetation in the form of shrubs and trees considered an essential component of their habitat (Grange 1948). Population estimates for sharp-tailed grouse are speculative; one estimate of spring breeding bird densities is $5-10 \mathrm{birds} / \mathrm{mi}^{2}$ ( $\mathrm{R}$. Watts personal communication). Known dancing grounds are shown on Figurre 4.

Late summer concentrations of nearly 500,000 mourning doves have been observed near the Musselshell River bottoms and exposed weedy flats along the reservoir on the west side of CMR. Other upland game birds, including sage grouse, gray partridge, ring-necked pheasants and Merriam's turkeys, occur in varying numbers and locations.

Several species of nongame birds occur seasonally on CMR. Birds considered common and very numerous at one or more seasons include redtailed hawks, marsh hawks, common nighthawks, poorwills, eastern kingbirds, prairie horned larks, bank swallows, black-billed magpies, pinyon jays, American robins, mountain bluebirds, Bohemian waxwings, house sparrows, western meadowlarks, yellow-headed blackbirds, red-winged blackbirds, Brewer's blackbirds, lark buntings, American goldfinches and chipping sparrows.

The CMR fishery resource is limited to Fort Peck Reservoir, the Dredge Cuts, the Missouri River above the reservoir and below the dam, Musselshell River and stocked ponds (Alvord 1979). Common sport fish include northern pike, walleye, lake trout, shovelnose sturgeon, sauger, burbot, paddlefish and channel catfish. Pallid sturgeon are present in small numbers and have been classified as a threatened species by the Endangered Fishes Committee of the American Fisheries Society (Alvord 1979). A commercial fishery exists on the reservoir involving goldeye, carp, river carpsucker, buffalo and freshwater drum.

Fisheries management is confined primarily to stocking operations from state and federal hatcheries and enforcement of regulations by the State of Montana. In addition, ongoing studies and research by MDFW\&P are defining requirements for paddlefish spawning; significant walleye spawning runs up Big Dry Creek have been documented (R. Johnson personal communication). The CMR fishery is limited by siltation of the lake 
CHARLES M. RUSSELL

NATIONAL WILDLIFE REFUGE

ENVIRONMENTAL STATEMENT

ELK HABITAT

AND

SHARP-TAILED GROUSE HABITAT

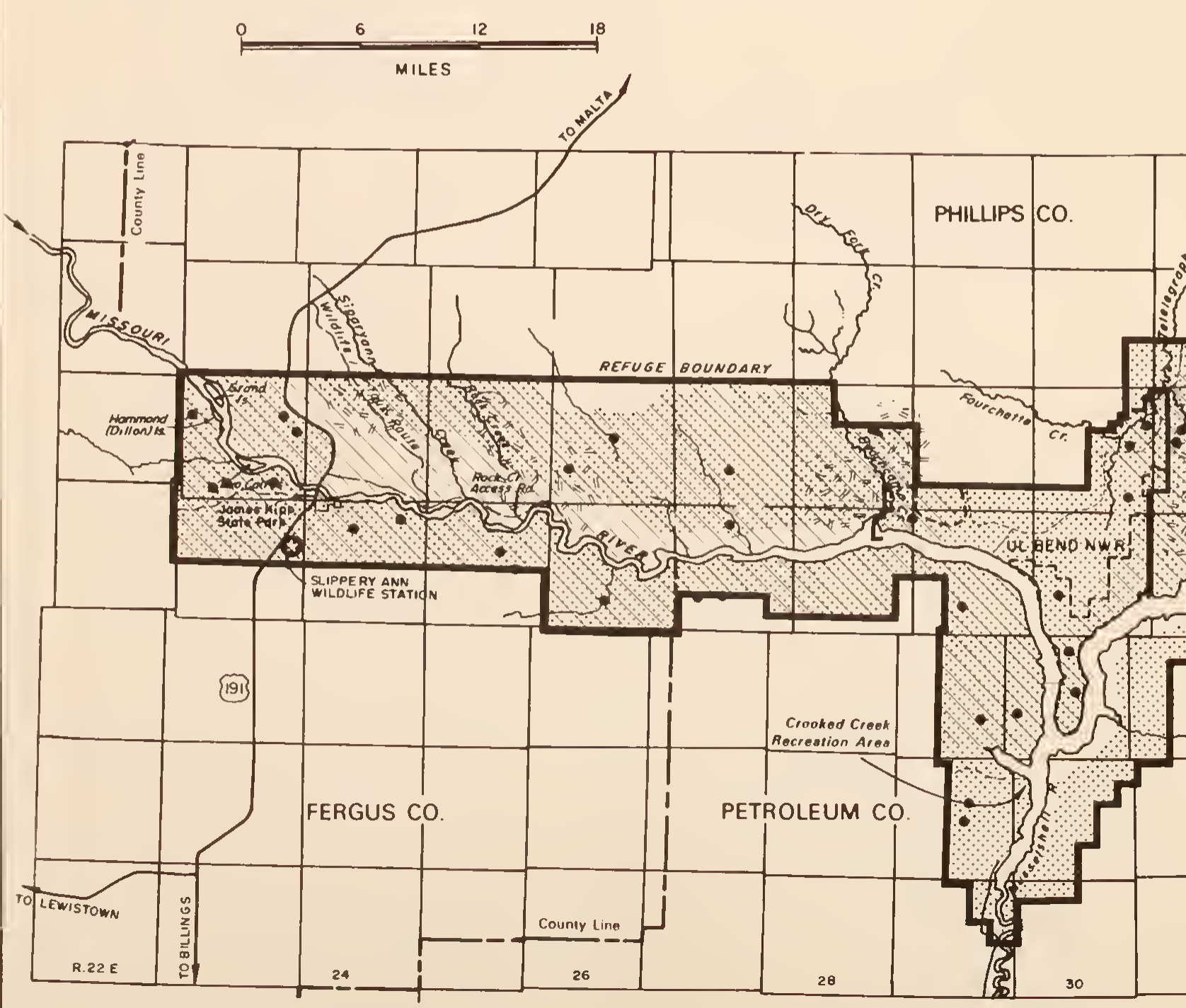

SHARP-TAILED GROUSE HABITAT

Overall Distrbution

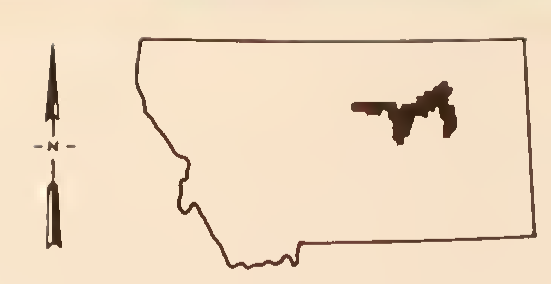

G. 4 ELK HABITAT AND

SHARP-TAILED GROUSE HABITAT
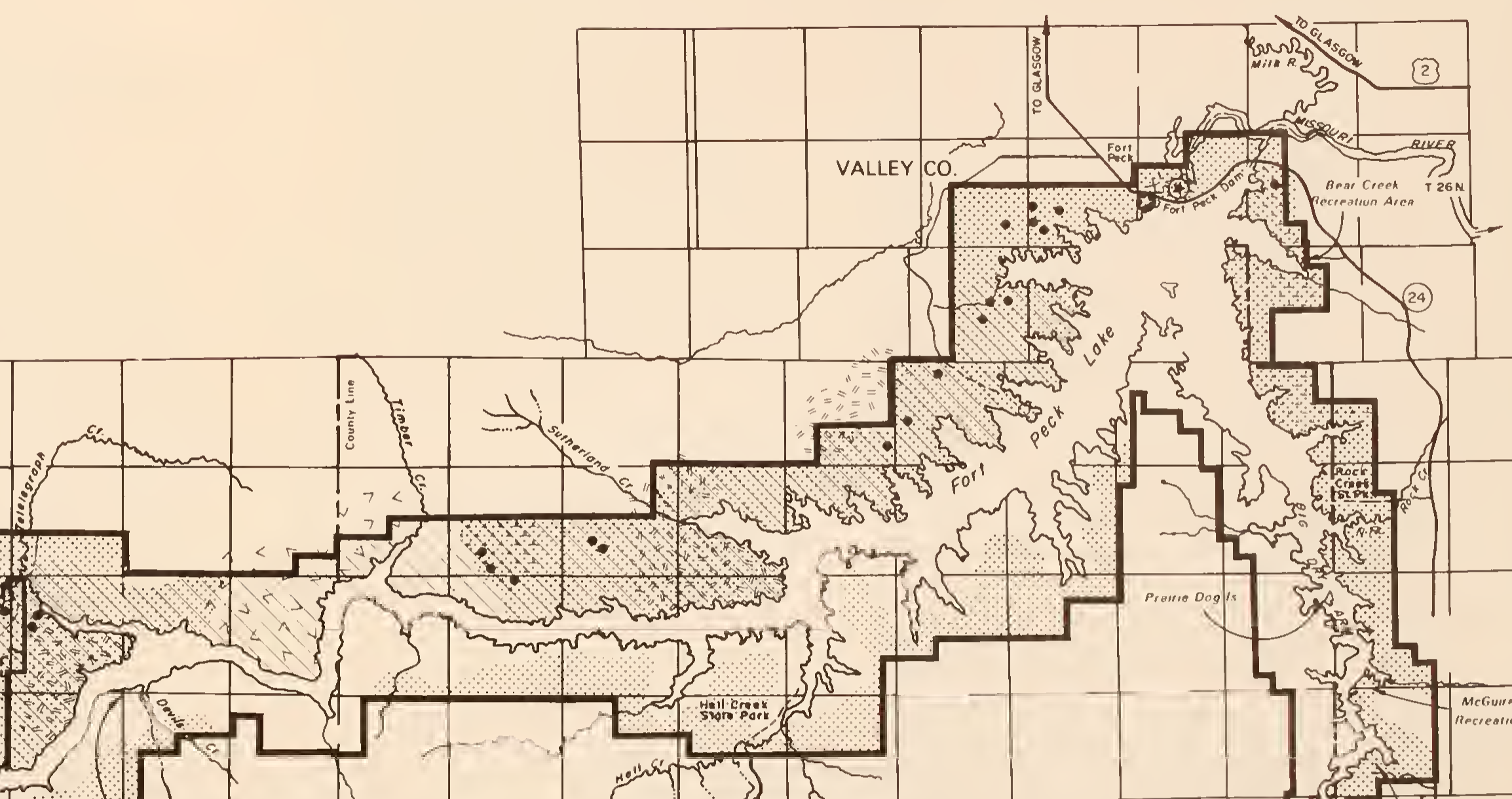

UNITED STATES DEPARTMENT OF THE INTERIOR

LEGEND

CHARLES M. RUSSELI NATIONAL WILDLIFE REFUGE

ENVIRONMENTAL STATEMENT

1:10verall Distribution

$=$ Silver Sage Bounons Ucell Oully Uuring Severo

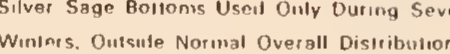

Overall Distribution

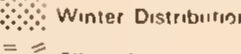

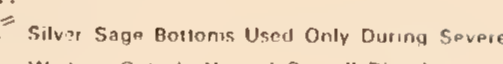

Normal Overall Distribution
FIG. 5

PRONGHORN HABITAT AND SAGE GROUSE HABITAT

\section{PRONGHORN HABITAT}

AND

SAGE GROUSE HABITAT

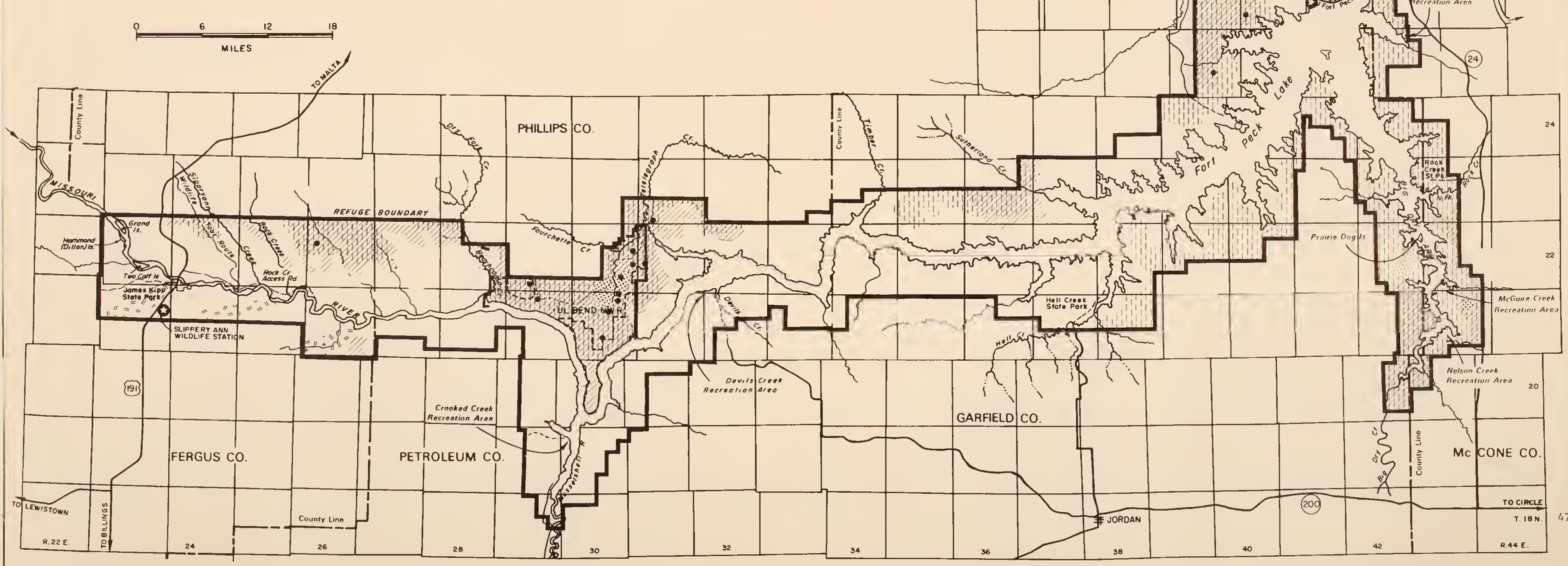



UNITED STATES DEPARTMENT OF THE INTERIOR

FISH AND WILDLIFE SERVICE

LEGEND

CHARLES M. RUSSELL

NATIONAL WILDLIFE REFUGE

ENVIRONMENTAL STATEMENT

Critical Winter Distribution

Possible Introduction Sires

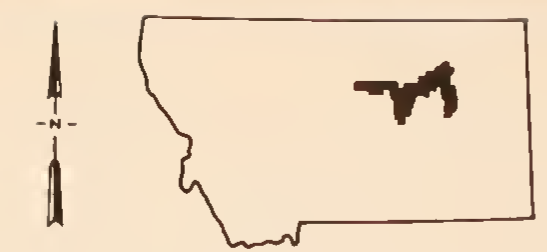

FIG. 6 BIGHORN SHEEP HABITAT

BIGHORN SHEEP HABITAT

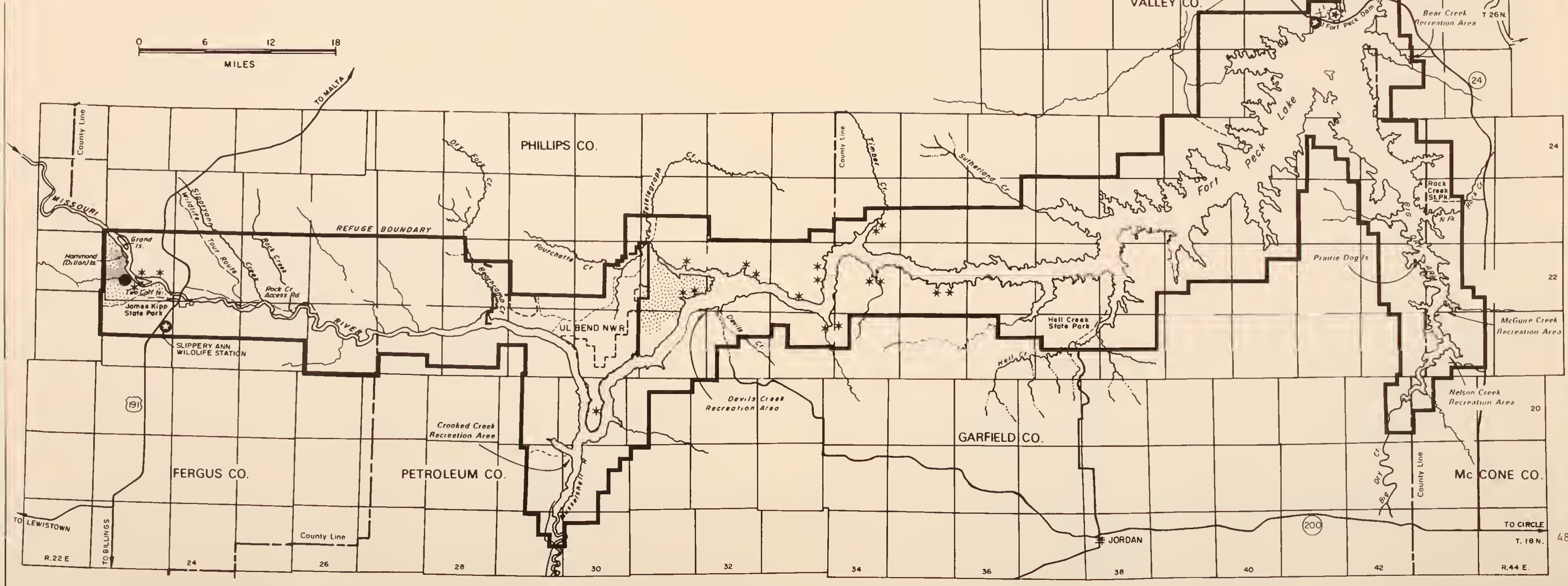



UNITED STATES DEPARTMENT OF THE INTERIOR

CHARLES M. RUSSELL

NATIONAL WILDLIFE REFUG

ENVIRONMENTAL STATEMENT

PRAIRIE DOG TOWNS

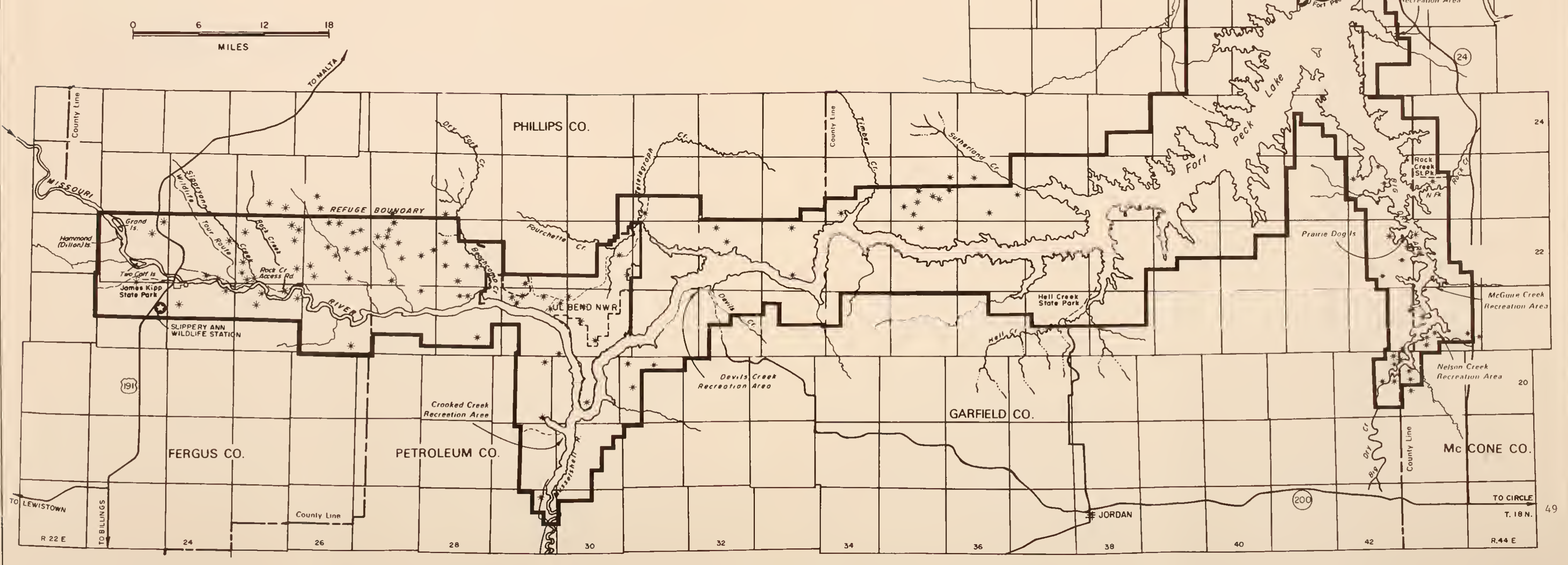



and fluctuating water levels which makes establishment of littoral zone vegetation needed for spawning habitat almost impossible. This problem is compounded by Fort Peck being the first mainstream reservoir on the Missouri which makes it difficult to control water levels. Due to these limitations, there is little that can be done to improve the current fishery management program. Small intermittent and continuous streams may provide spawning and nursery habitat. However, no information is available on these streams.

Six species of amphibians and 10 reptiles are known to occur in eastern Montana with ranges overlapping CMR. None of these species is endangered or threatened and none has commercial value.

Peregrine falcons often winter in the vicinity of Fort Peck where they prey on winter flocks of ducks and other birds. Occasional sightings have also been made at the west edge of CMR. Migrating bald eagles rest along the shoreline of Fort Peck Reservoir as well as along the Missouri River. One nest is thought to have been built in 1966 along Two Calf Creek where it joins the Missouri River (C. Jones personal communication). In 1967, a black-footed ferret survey reported ferret sign on two prairie dog towns although no ferrets were observed (Fortenbery 1967).

No endangered or threatened species of plants are known to occur on CMR (K. Lackshewitz personal communication). However, the refuge may be within the geographical distribution of Rorippa calycina, a species of watercress classified as potentially threatened or endangered in Montana.

\section{RECREATION AND CULTURAL RESOURCES}

Within a 150-mile radius of CMR there are numerous competing recreation resources which constitute a significant array of sites and areas available to the public (Table 7). Because they are so extensive in size and located in a lightly populated section of the country, they generally receive only limited use. In addition, there are many hiking and jeep trails, ghost towns, state parks, wildlife areas and other recreation opportunities available to the public that tend to compete with similar opportunities available on the refuge.

Major recreation attractions on CMR include the 249,000-acre Fort Peck Reservoir and the scenic segment of the Upper Missouri National Wild and Scenic River administered by BLM. A designated national wilderness area is located at UL Bend and fifteen additional wilderness areas comprising about 161,000 acres have been proposed for inclusion in the National Wilderness Preservation System and are awaiting Congressional action.

Considering its vast size, CMR contains relatively few developed recreation areas. Most of these are $\mathrm{COE}$ areas located in the vicinity of Fort Peck Townsite and the Big Dry Arm of the reservoir. Three state parks are administered by MDFW\&P. FWS manages the bulk of undeveloped lands on CMR. The only developed recreation areas administered by this agency are a wildlife tour route, boat access sites and a wildlife display pasture at Lewistown. 
Table 7. Competing recreation resources on and near the Charles $M$. Russell National Wildlife Refuge, Montana.

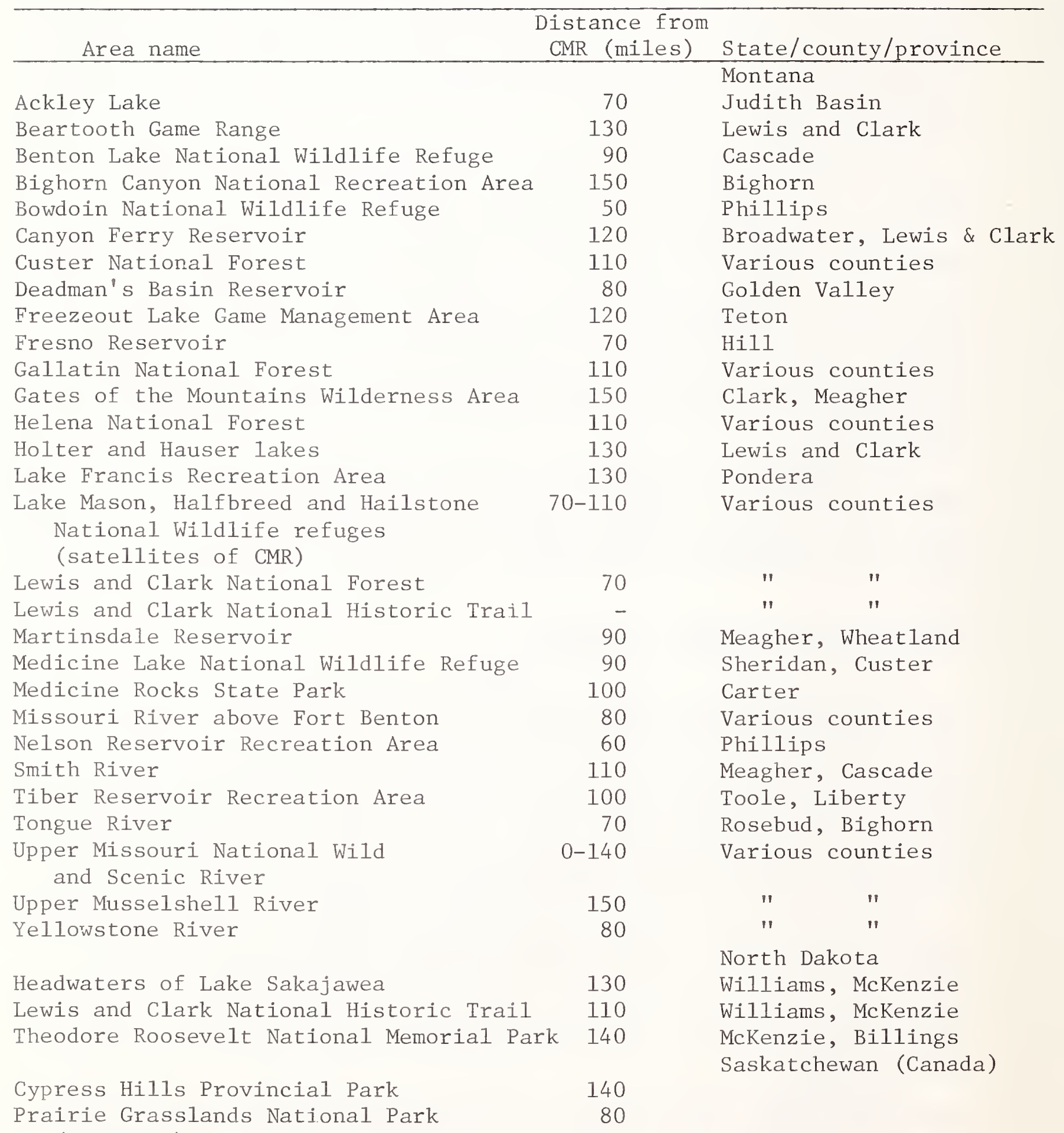

Source: Montana Department of Fish and Game 1978, North Dakota State Outdoor Recreation Agency 1975, Saskatchewan Tourism and Renewable Resources 1977. 
Private cabins are located at four areas on federal land. At present there are 428 lots, 337 of which currently have structures on them. These sites are leased by $\mathrm{COE}$ to private individuals. Figure 8 shows existing recreation facilities.

An estimated 357,000 visitor days of use occurred on CMR in 1978. Based on information provided by BLM, the scenic river segment of the Upper Missouri National Wild and Scenic River within the refuge provided about 2500 floater days of this use (W. Cutler personal communication). Based on a preliminary survey conducted on the refuge in 1978, 91 percent of visitors were Montanans (Fish and Wildlife Service 1978). Approximately 75 percent of the visitation to CMR originated within a 150-mile radius; 20 percent of the visitors came from places between 150-500 miles distant and the remaining 5 percent originated from points beyond.

CMR is open to camping for two continuous weeks at any one location within any 30-day period. Fishing and hunting, together with other wildlife-related activities, are permitted on the refuge. Hunting is permitted, except in certain areas, for elk, mule and white-tailed deer, pronghorns, waterfowl, sage grouse, sharp-tailed grouse, gray partridge, ring-necked pheasants and turkeys under state and federal regulations. In 1979, free elk permits for archery hunting were required for the first time. The harvest of game animals in 1979 included 150 elk by gun and 70 by archery, 400 deer by gun and 30 by archery, 7 turkeys and 55 pronghorns (Fish and Wildlife Service 1979). Waterfowl and upland game hunting was considered light. Trapping is allowed only as needed to protect resource values. Nonwildlife activities such as off-road vehicle use, rock hounding, collecting artifacts and tree cutting are prohibited but still occur.

Among the most popular activities on the refuge in 1978 were viewing scenery and exhibits, followed by picnicking, fishing, power boating and camping (Table 8 ). The methodology used in estimating visitor use is explained in Appendix 17.

Recreation use is concentrated at a few locations on the refuge due to a lack of good roads and access to recreation areas which prevent people from fully utilizing the resources. The boating potential on Fort Peck Reservoir has not been realized (Montana Department of Fish and Game 1978).

Because livestock occur near public use areas, there are isolated instances of minor conflicts with recreationists, such as the presence of animals and their feces in camp-picnic areas, temporary blocking of roads by small herds of cattle and spooking of game during the hunting season. Visitors passing through the refuge usually see more livestock than wild animals.

There generally have been increases in participation for all recreation activities in those portions of Montana, North Dakota, Saskatchewan and Alberta within a 150-mile radius of the refuge. In other areas, some of these activities show decreases, such as horseback riding on trails, hunting for white-tailed deer and pronghorns and ice fishing. 
Table 8. Estimates of current visitation on Charles M. Russell National Wildlife Refuge, Montana.

\begin{tabular}{|c|c|c|c|}
\hline \multirow[b]{2}{*}{ Visitation type } & \multicolumn{3}{|c|}{ Visitor days (000's) } \\
\hline & $\begin{array}{r}\text { FWS } \\
1978\end{array}$ & $\begin{array}{c}\text { BLM/COE/State } \\
1978\end{array}$ & $\begin{array}{r}1978 \\
\text { Totals }\end{array}$ \\
\hline \multicolumn{4}{|l|}{ Wildlife related } \\
\hline Cultural studies & * & - & $*$ \\
\hline Environmental education & * & - & $*$ \\
\hline \multicolumn{4}{|l|}{ Interpretation } \\
\hline Viewing scenery-exhibits & 12 & 92 & 104 \\
\hline \multicolumn{4}{|l|}{ Recreation } \\
\hline Hunting & 10 & 2 & 12 \\
\hline Fishing & 5 & 46 & 51 \\
\hline Trapping & $*$ & - & $*$ \\
\hline Nature observation & 3 & - & 3 \\
\hline Wildlife photography & 2 & - & 2 \\
\hline Backcountry travel (motor) & 1 & - & 1 \\
\hline Backcountry trave1 (nonmotor) & $*$ & - & $*$ \\
\hline \multicolumn{4}{|l|}{$\begin{array}{l}\text { Nonwildlife related } \\
\text { Recreation }\end{array}$} \\
\hline Camping & 13 & 19 & 32 \\
\hline Picnicking & 2 & 75 & 77 \\
\hline Beach swimming & 3 & 12 & 15 \\
\hline Powerboating & 6 & 32 & 38 \\
\hline Nonpowerboating & 1 & 5 & 6 \\
\hline Waterskiing & 1 & 10 & 11 \\
\hline Backpacking-hiking & $*$ & - & $*$ \\
\hline Visiting special sites & 1 & - & 1 \\
\hline Horseback riding & $\dot{*}$ & - & $\dot{x}$ \\
\hline Other & 2 & - & 2 \\
\hline Totals & 64 & 293 & 357 \\
\hline
\end{tabular}

*Less than 1000 visitor days. 
Recreation needs generally rank lowest in that area immediately surrounding the refuge on the north and east. This is explained by the lack of major urban centers there, compared to those areas in the south and west where the larger cities of Billings and Great Falls are located. In the latter areas, activities for which needs are most critical include nonurban swimming, horseback riding and backpacking. In the small part of North Dakota lying within the 150-mile radius of the refuge to the east, needs have been identified for such activities as picnicking, beach swimming and boating (Montana Department of Fish and Game 1978, North Dakota State Outdoor Recreation Agency 1975, Saskatchewan Tourism and Renewable Resources 1977). No information was available on recreation needs for Alberta and Saskatchewan.

Proposed energy development in Eastern Montana could greatly increase the demand for recreation while increasing gasoline prices could decrease recreation use on the refuge. No information is available on either of these items.

\section{SOCIOECONOMICS}

The region around CMR which includes the counties of Fergus, Garfield, McCone, Petroleum, Phillips and Valley, has been characterized by relatively slow economic growth with an economy based on the production of grain and livestock. Following a regional trend, the number of agricultural operations has decreased while their size and value has increased. Most agricultural products are marketed outside the area.

Farming is the largest single income producing sector of the sixcounty regional economy (Appendix 11). Gross income from this sector in 1975 amounted to $\$ 70.9$ million and represented about 42 percent of the total income. Government led the nonfarm industries as a source of income followed by wholesale and retail trade, services and contract construction. Range livestock-related earnings for the region averaged $\$ 50.8$ million annually between 1970-75, based on a supply of about 599,200 animals (sheep and cattle). A total of about 6,050,860 AUMs is required to sustain this livestock base (Bureau of Land Management 1979).

Total regional income from all sources was $\$ 166,922,000$ in 1975 compared to $\$ 101,694,000$ in 1970 (Table 9). Data indicate that five of the six counties, (Petroleum County excepted), had per capita income greater than the Montana average in 1974 (Table 10). Also, growth in per capita income for 1969-74 in the region was significant relative to per capita income growth in the US as a whole.

Between 1960-70 employment decreased in the region (Appendix 12). However, since 1972 all counties have experienced increases in the number of persons employed over 1970. The unemployment rate increased an average of 4.6 percent from 1972-77, considerably below the statewide unemployment rate of 5.8 percent for December 1977.

Based on a preliminary survey of visitor use, costs of goods and services purchased by visitors to CMR totaled about $\$ 32 /$ person (Fish and Wildlife Service 1978). Assuming these costs are representative for the 357,000 visitors who came to CMR, about $\$ 11.4$ million was 
Table 9. Farm income data for a six-county region at Charles M. Russe11 National Wildife Refuge, Montana.

\begin{tabular}{|c|c|c|c|c|c|c|}
\hline \multirow[b]{2}{*}{ County } & \multicolumn{2}{|c|}{$\begin{array}{c}\text { Total farm } \\
\text { income }\left(\$ 000^{\prime} \mathrm{s}\right)\end{array}$} & $\begin{array}{l}\text { Total } \\
\text { income }\end{array}$ & $\begin{array}{l}\text { (on-farm } \\
\left(\$ 000^{\prime} \mathrm{s}\right)\end{array}$ & \multicolumn{2}{|c|}{$\begin{array}{c}\text { Total income } \\
\left(\$ 000^{\prime} \mathrm{s}\right)\end{array}$} \\
\hline & 1970 & 1975 & 1970 & 1975 & 1970 & 1975 \\
\hline Fergus & 9638 & $\$ 16,722$ & $\$ 21,092$ & $\$ 32,703$ & $\$ 30,730$ & $\$ 49,425$ \\
\hline Garfield & 4277 & 7093 & 1657 & 2658 & 5934 & 9751 \\
\hline McCone & 4319 & 11,196 & 3632 & 7222 & 7951 & 18,418 \\
\hline Petroleum & 1650 & 178 & 658 & 882 & 2308 & 1060 \\
\hline Phillips & 10,376 & 13,478 & 6331 & 10,955 & 16,707 & 24,433 \\
\hline Valley & 12,699 & 22,267 & 25,365 & 41,568 & 38,064 & 63,835 \\
\hline $\begin{array}{c}\text { Six-county } \\
\text { tota } 1\end{array}$ & $\$ 42,959$ & $\$ 70,934$ & $\$ 58,735$ & $\$ 95,988$ & $\$ 101,694$ & $\$ 166,922$ \\
\hline
\end{tabular}

Source: Montana Department of Community Affairs 1978.

Table 10. Comparative 1974 per capita income for a six-county region at Charles M. Russell National Wildlife Refuge, Montana.

\begin{tabular}{lcc}
\hline County-state & $\begin{array}{c}\text { Per capita } \\
\text { income }\end{array}$ & $\begin{array}{c}\text { Average annual } \\
\text { increase }\end{array}$ \\
\hline Fergus & & $1969-74(\%)$ \\
Garfield & $\$ 4722$ & 11.4 \\
McCone & 4449 & 11.9 \\
Petroleum & 6801 & 16.2 \\
Phillips & 3751 & 9.4 \\
Valley & 4413 & 12.2 \\
Montana & 4681 & 12.6 \\
US & 4347 & 9.6 \\
\hline
\end{tabular}

Source: Bureau of the Census 1977. 
injected into the economy for food, lodging, gasoline and related items.

The installed electrical generation capacity of Fort Peck Dam and powerplant totals $165,000 \mathrm{KW}$. The reservoir now produces over $\$ 13$ million in average annual benefits derived from power production, flood control, navigation, irrigation, rentals from leasing of land and recreation at COE areas (Corps of Engineers 1977).

Under provisions of the Refuge Revenue Sharing Act of 1978 (Public Law 95-469) as amended, payments are made to local governments. A total of $\$ 15,133.54$ was distributed to the six counties in the CMR region in fiscal year 1978 under terms of this Act (Fish and Wildlife Service 1978).

In 1979, 67 grazing allotments (Fig. 9) were partially or totally located on CMR; 87 individuals, companies or associations grazed livestock on the refuge. CMR records for that year indicate 60,108 federal livestock AUMs were authorized on the refuge with 3584 federal AUMs in a nonuse status and 56,524 federal AUMs representing actual use. Private and state AUMs totalled 12,135 within the refuge boundary.

Federal grazing fees were \$1.89/AUM in 1979. The 56,524 AUMs of grazing on federal range represented $\$ 106,830$ in revenues paid to the US Treasury.

MDSL has a sliding scale for determining the amount paid per AUM on state land. This is based upon the carrying capacity of a given parcel for the grazing season. The rates for less than 14 head/section are \$3.54/AUM, for 14-19 head, \$3.64/AUM and over 19 head, \$3.74/AUM. Most of the state lands on CMR fall in the "under 14 head" category (G. Brandenburg personal communication). AUMs in Montana on private rental lands were a minimum of \$8.40/AUM in 1979 (Economic, Statistics and Cooperative Service 1979).

In 1979 approximately 800 acres of CMR were farmed. This consisted of about 70 acres of grain, 450 acres of hay and 280 acres of dense nesting cover. FWS's share was 20 acres of grain crops, 20 acres of hay and 280 acres of dense nesting cover. No data are available on income derived by the eight cooperators from the crops they produced. However, considering the acreage involved, the amount was probably less than $\$ 10,000$.

The CMR area is rural and sparsely populated. CMR occupies portions of six counties which had a 1970 population of about 34,000 (Table 11) and a 1975 estimated population of approximately 36,500. Three towns adjacent to CMR and their 1970 populations are Glasgow, 20 miles north (population 4700); Lewistown, 65 miles southwest (population 6437) and Malta, 69 miles north (population 2195). Several other smaller towns and villages border the area.

As with most rural areas in the US, there was a general population decline in the six Montana counties contiguous to CMR from 1960-70. In the period 1960-70, while the population in Montana as a whole was increasing by nearly 3 percent, these counties decreased by nearly 28 percent. However, from 1970-75 this trend was at least temporarily reversed because population in the six-county area increased by 7 percent.

Population growth for the area within 150 miles of the refuge, excluding Canada, is expected to increase by about 85,000 people between 


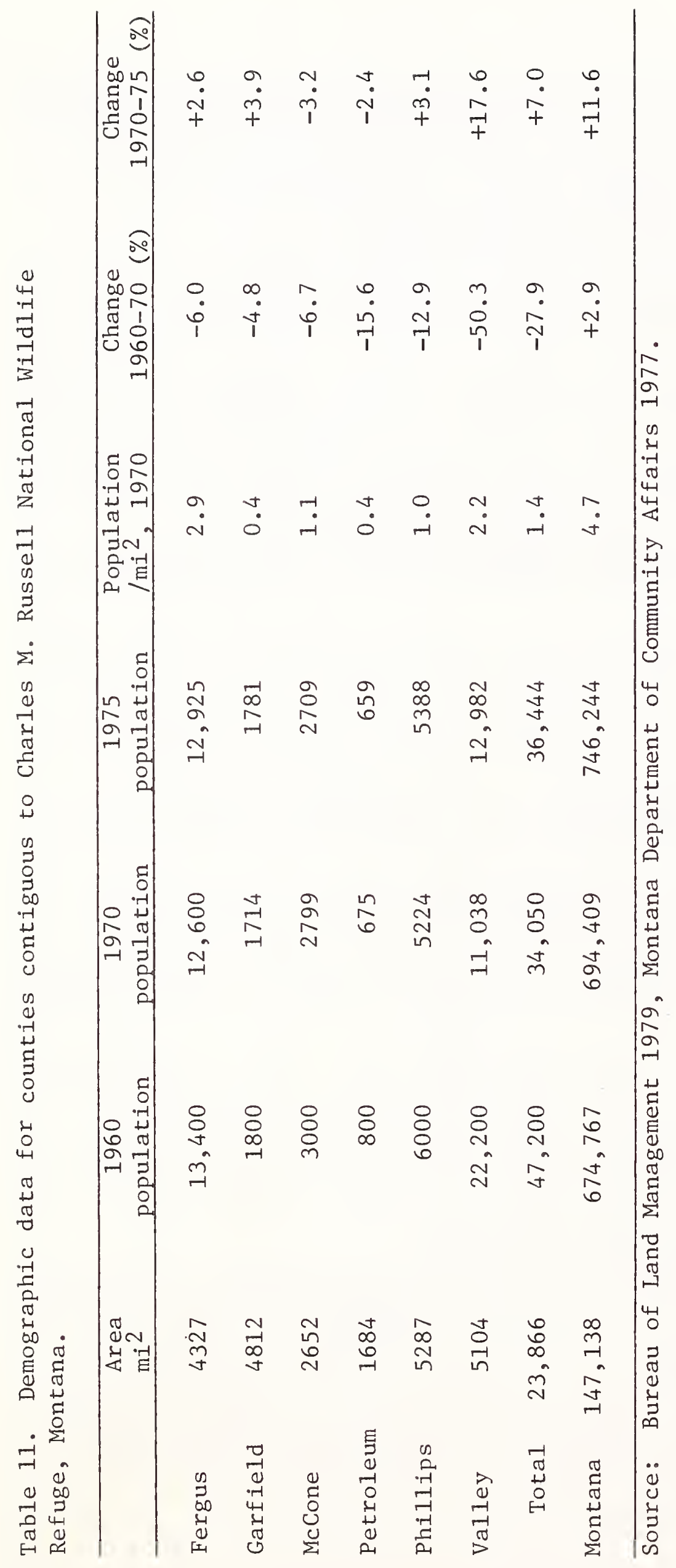


CHARLES M. RUSSELL

NATIONAL WILDLIFE REFUGE

ENVIRONMENTAL STATEMENT

Number and Name

1. Antelope Crenk

2 E Elipperv Ann

3 Rock Creek

$\begin{array}{lll}\text { Nichols Coullee } & 20 & \text { fort Peck Con } \\ \text { Beauchamp Creek } & 21 & \text { Bear Creek }\end{array}$

33 Box Creek

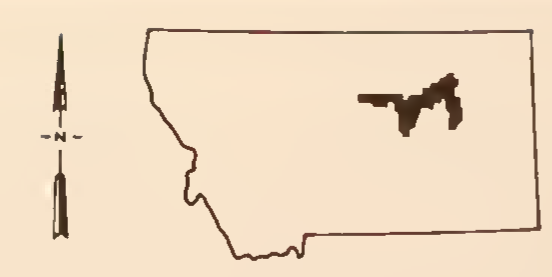

FIG. 9 GRAZING ALLOTMENTS

GRAZING ALLOTMENTS

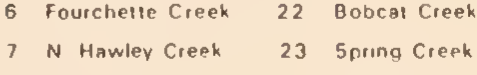

36 Sage Creek Point 52 Deadman Coulee

8 Telegraph Creek 24 5and Arroyo/ Rock Creek 4D Crooked Creek 5679 Tral

9 UL Bend 25 Aock Creek

10 Box Eldor $\# 325 \quad 26$ Bug Creek

27 Nelson Creek

barriers which separate them

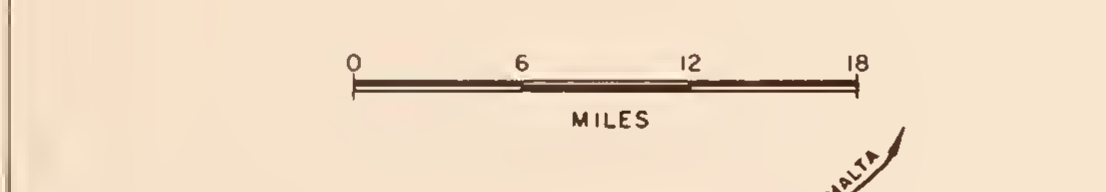

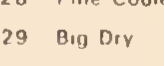

14 Carpenter Creek 30 Snap Creok

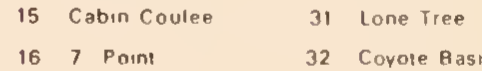

11 Hell Cieek

57 Deer Coulee

58 5oda Creek

$\begin{array}{ll}59 & \text { Musselshell Trat } \\ 60 & \text { Hansen Flat }\end{array}$

61 E Indian Butre

45 Buly Cour

46 Billy Creek

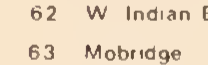

642 call

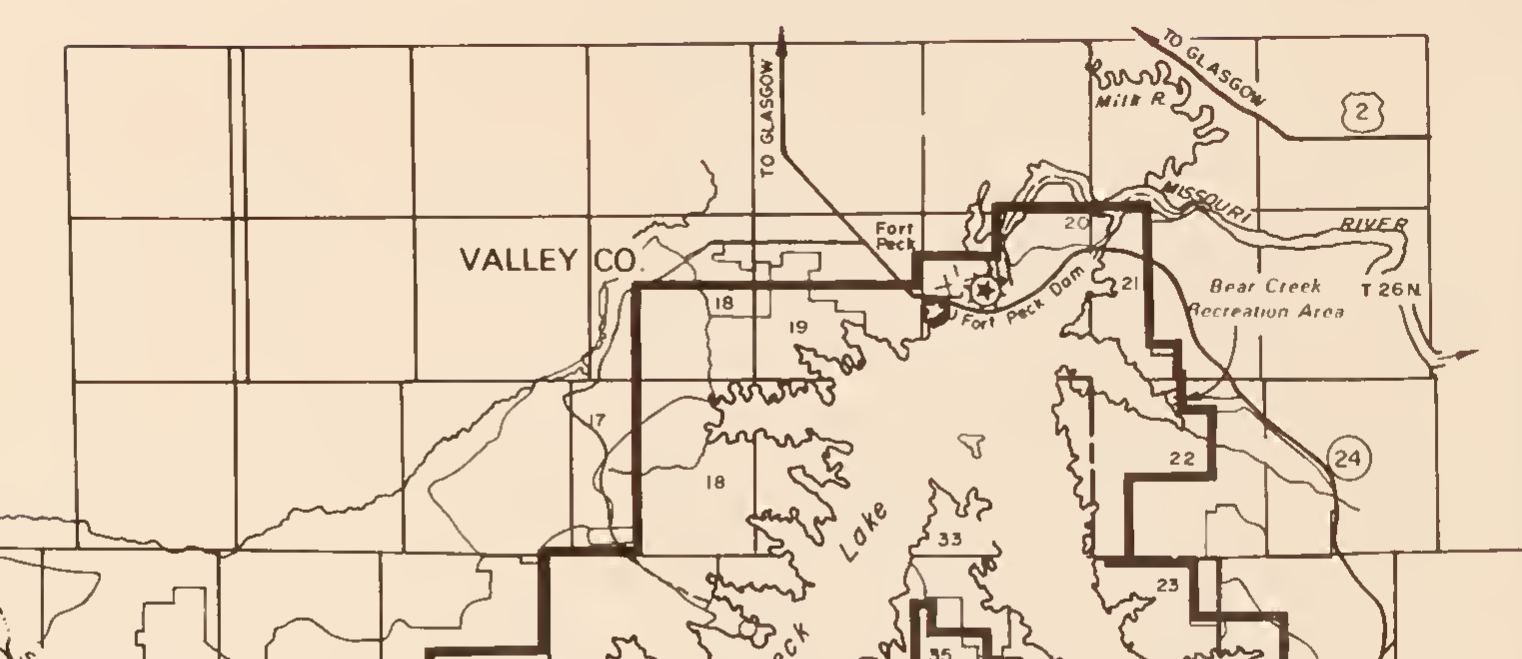
(1)

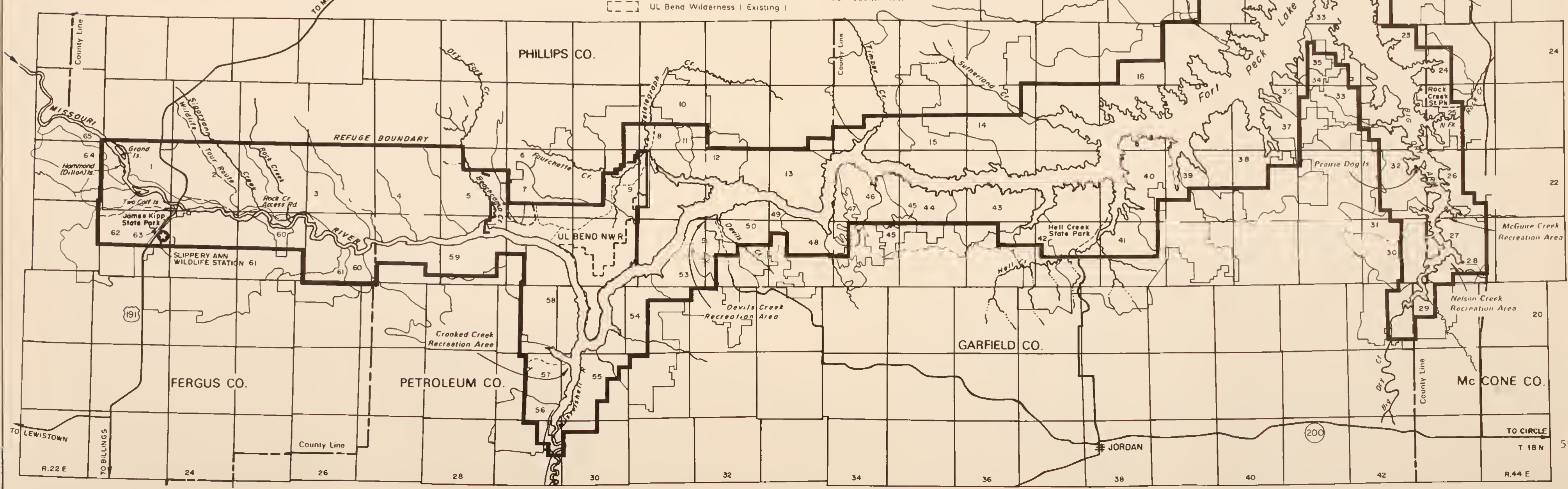



1978-2000 (Montana Department of Community Affairs 1978, Murdock and Ostenson 1976). Potential energy developments, especially coal, could significantly impact population growth. However, the magnitude of this impact is presently unknown.

The age distribution of people residing in the region is comparable to that of Montana as a whole. Compared to the state, the region has approximately half as many physicians per person; two counties have no physicians. Only 5 percent of Montana's population resides in the sixcounty CMR region, making this a comparatively undeveloped area with few of the major problems faced in rapidly growing regions.

The general decline in regional population parallels a similar decrease in the number of farms between 1969-74. Although the region is still predominantly rural, it seems there is a trend toward urbanization.

Median family income for the region in 1970 averaged about $\$ 900$ less than for the state and the number of families classified at the poverty level was higher in the region. Those who continue to farm need more land than previously to maintain their standard of living.

Approximately 7 percent of the property valuation and 6 percent of the taxable valuation in Montana is located in the six-county CMR region. Most of this value is associated with Fergus and Valley counties where more than half the regional population is concentrated.

Nearly 6 percent of the 1974 property taxes in Montana were paid by residents of the region where only 5 percent of the population lives. This is indicative of the higher per capita taxation in the region, which was slightly more than $\$ 150$ higher per person than for the state.

Public opinion surveyed at the state level tends to be conservative as it relates to social and cultural attitudes. Billings (1977) noted, "...Montana's game animals are an acknowledged resource for residents and non-residents, and for hunters and general observers. Over 55\% of the men and over $20 \%$ of the women in Montana claim to be hunters, and fewer than one in seven oppose hunting. Whether they hunt or not, approximately $70 \%$ of Montana's residents make special efforts to observe wildlife in its natural setting."

Comments received at public meetings, through correspondence and personal contacts conducted as part of the overall planning effort covered the full range of management interests, from protection and proper management of wildlife to management of CMR primarily for livestock. Individuals who rely on livestock grazing for a living favored multiple use of the refuge and minimum interference by government in cattle operations as historically practiced. In contrast, those sensitive to wildlife favored management of CMR primarily for wildlife. Special interest groups representing agriculture generally preferred to include livestock interests on a planning and advisory board for CMR and to continue grazing as in the past. Those who represented wildlife interests preferred habitat preservation for wildlife through appropriate restraints such as conservative grazing by domestic livestock. Others wanted no grazing, hunting or roads; still others wanted mass recreation and development. 


\section{ENVIRONMENTAL CONSEQUENCES}

This chapter analyzes the significant environmental effects of the five alternatives discussed in Section II. The five elements or management actions common to all alternatives, which may significantly affect the environmental quality of the refuge are endangered and unique species introduction, wildlife habitat management, recreation and cultural resources management, forage allocation and range developments.

The following basic assumptions were made for all alternatives to facilitate analysis:

1) The chosen alternative would be implemented if adequate funding and manpower are made available.

2) After a management plan is selected, actions that are implemented would be monitored. Necessary adjustments would be made to correct those actions that are not meeting objectives.

3) Short-term impacts are those which would occur during implementation approximately 1980 through 1985; long-term impacts are those projected to exist when the wildlife objectives are met (i.e. by the year 2000 or later).

4) Unauthorized human and livestock use would be strictly controlled under each alternative and would not be a significant factor affecting environmental quality.

5) Because habitat is recognized as the key to wildlife abundance, this document emphasizes habitat quality and quantity rather than wild animal population numbers or densities. Where possible the habitat capability to support numbers of animals per unit area have been used. Establishment of high quality habitat will provide adequate populations of wildlife species within constraints imposed by drought, severe winters, disease and other variables which are largely uncontrollable. 


\section{ALTERNATIVE A}

(NO ACTION)

\section{SOILS-WATERSHED}

Habitat management to control all burning would result in coniferous communities proceeding to climax and could increase the potential for destructive wildfires. If areas were burned it could result in temporary loss of vegetative cover, increased runoff and soil loss until vegetation is restored. In favorable years, fall "green-up" can occur and eliminate erosion problems on areas burned the preceding summer. Once herbaceous vegetation is restored, erosion would probably be reduced below levels associated with the coniferous forest communities. Eichhorn and Watts (1974) observed that erosion potential was less for coniferous forest sites that had been burned and replaced with a grass-land community as compared to forested communities with their sparse understory vegetation.

Grazing patterns would not significantly change present ranges of bare ground (60-75 percent) on marginal breaks, badlands or shale areas or those ranges (20-42 percent) presently existing on better quality clayey, sandy or silty range sites. However, a present slight upward trend in range condition would provide for some increased plant and litter cover over the refuge as a whole by the year 2000. This would provide a slight enhancement to soil productivity and watershed quality as compared to present conditions.

Livestock concentration areas, particularly around watering areas would continue to exhibit soil erosion and watershed quality problems because of poorer range conditions and trampling effects. Marginal sites that are highly fragile such as thin breaks, badlands and shale would receive some livestock use under this alternative. Any use on these areas by livestock tends to increase soil or parent material loss because of vegetation cover removal and livestock movements (W. Larsen personal communication). Poorly located reservoirs would continue to silt-in at accelerated rates. Irretrievable soil losses would occur as a result of present grazing practices. Lusby (1970) found that runoff rates on Mancos shale derived soils, which react much like Bearpaw shale, averaged 30 percent less on ungrazed watersheds versus grazed watersheds and sediment yields were about 45 percent less. His studies indicated that runoff was directly related to the percentage of bare soil on the watershed with hydrologic changes caused by the trampling of livestock on soil loosened by frost heavings.

Continued loss of soil on the most productive sites would ultimately lower site productivity if soil losses exceed soil formation rates. No estimates for determining the amounts of soil loss were made. However, this alternative would rank as number one in terms of soil loss rates for the various alternatives considered.

Although refuge-wide range condition shows a slight upward trend which would bring some long-term increase in productivity, short-term enhancement would be minimal. Soil lost as a result of accelerated 
(man-caused) erosion would be a long-term impact and an irretrievable 1oss.

\section{WILDLIFE HABITAT-RANGE RESOURCES}

Fire management would involve suppression of all wildfires. There would be no prescribed burning or "let-burn" philosophy. This could reduce the extent of seral communities and eventually the diversity of wildlife habitat. The existing fisheries management program would result in no significant environmental impacts.

Wildlife habitat would not change substantially under the No Action alternative. Lack of residual cover and shrubs would remain as major problems. Wildlife population levels would remain about the same also.

Bighorn sheep habitat would be adversely affected due to grazing by cattle on winter range near Two Calf Creek (Constan 1978). Continued competition with livestock and periodic severe winters would keep sheep at low numbers and preclude any effective management program.

Sharp-tailed grouse habitat would remain in fair condition. Eighty-one percent of all samples taken in the 1978 survey indicated sharp-tailed grouse lack 8-10 inches of residual cover required for successful nesting (Christenson 1971, Sisson 1976). Habitat to support 5-10 birds $/ \mathrm{mi}^{2}$ would be maintained.

The quantity and quality of forbs would be limited. Insufficient forb productivity occurred on 46 percent of the areas sampled for pronghorns and 65 percent of the areas sampled for mule deer. They feed on such plants from spring to late summer (Mackie 1970, Hoover et a1. 1959, Cole and Wilkins 1958).

Vegetation around ponds would remain inadequate to provide nesting cover for waterfowl. Bent (1923), Bennett (1938), Burgess et al. (1965) and Drewien and Springer (1969) stated vegetation less than 1.5 feet tall and covering less than 75 percent of the ground is inadequate for nesting waterfowl. The Creston Valley Wildlife Management Authority (1974) cited several studies which correlated high waterfowl nesting densities and success rates with undisturbed stands of vegetation (Nelson 1972, Schranck 1966, Bue et al. 1952, Keith 1961). On 89 percent of the CMR ponds sampled in 1978 herbaceous upland vegetation was less than 1 foot tall and had less than 69 percent ground cover (Fish and Wildife Service 1978). Grazing by livestock has resulted in less than optimal waterfowl habitat conditions on many potentially suitable ponds on CMR.

Rodents lacked sufficient cover on 79 percent of sites sampled and this condition would persist. This would lower quality of hunting habitat for raptors and terrestrial carnivores.

Trampling and consumption of desirable browse species would be extensive; 75-90 percent of all areas sampled for habitat quality had inadequate browse (Fish and Wildlife Service 1978). Several livestock allotments on the Big Dry Arm demonstrate the effects of substantial livestock grazing, which has resulted in poor browse communities. Other allotments in this area that have experienced light or no livestock use in recent years have well developed browse communities. A static or downward trend in these communities would continue, meaning inadequate 
food and cover for sharp-tailed grouse and mule deer which rely heavily upon hardwood draws for portions of their life requirements (Severson 1966). This would help hold the deer population at the estimated level of 5-6 deer $/ \mathrm{mi}^{2}$. The present browse communities would probably not experience the slight upward trend in condition that the refuge as a whole would experience. Shrub communities would continue to receive a disproportionate amount of livestock use, which would be reflected by static or deteriorating conditions.

Dense stands of big sage are lacking on 67 percent of the sagebrush areas sampled. These food and cover requirements are needed for pronghorns and sage grouse (Bayless 1969, Wallstead 1971, Klebenow 1969). This is especially true in Garfield and McCone counties and the central Phillips County portion of CMR, which contains the primary range for pronghorns. Silver sage, a prime winter food for pronghorns (D. Pyrah personal communication, Cole and Wilkins 1958), is lacking in the central Phillips County area. Livestock use under No Action would tend to perpetuate or expand the existing sagebrush flat areas by their use patterns (Kindschy 1977). Moderate to heavy livestock grazing during spring and summer favors shrubs such as big and silver sage at the expense of more palatable grasses and forbs (Smith 1979). The expected result would be to benefit the present sagebrush communities because of present use patterns by livestock. Although range conditions may be actually lowered in these areas, some habitat enhancement for such species as pronghorns and sage grouse could be expected because of possible sagebrush expansion.

Security cover for elk in the form of dense canopies of ponderosa pine, juniper and pine-juniper (Campbel1 1978) would continue to be inadequate on the north side of the reservoir. This lack of security cover plus the presence of numerous roads and their associated vehicular traffic causes elk to widely disperse during the hunting season and some animals do not return. Herds would remain at their current size of 1300-1500 over-wintering animals. The presence of numerous roads for which no adequate control of access exists would continue to lower habitat values for elk and deer. Perry and Overly (1977) found that roads and disturbances associated with roads exerted a considerable influence on $e 1 k$ and deer use of habitat. E1k use was reduced by 95 percent and deer use by 100 percent under the most extreme case studied, which was a "main road" in a meadow situation. The lack of dense tree stands also means lack of thermal cover (Forest Service 1977).

The riparian areas along the Missouri River would be maintained for white-tailed deer through maintenance of present fences. These areas are in good condition and would remain in about the same condition (Fish and Wildlife Service 1978).

Minor riparian areas along continuous and intermittent streams across the refuge are not fenced and thus are accessible to cattle. This would perpetuate the existing poor deciduous browse conditions for wildlife. Severson and Boldt (1978) indicated livestock use in shrubby draws results in lack of shrub production because of tight sod-bound soil, lower moisture infiltration and higher soil temperatures. 
Off-refuge impacts associated with No Action would be minimal. Habitat quality for wildlife would probably remain unchanged as a result of maintaining present livestock levels on the refuge and wildlife objectives would not be met.

Coyotes can cause significant economic loss to ranchers. Removal of the individual animals responsible for the damage would eliminate or reduce the problem and have no lasting effects on predator populations. Avoiding control of prairie dogs or other small mammals would allow healthy, productive populations of prairie dogs and $30+$ species associated with them. It would preclude any possible killing of blackfooted ferrets.

The effect of coyote depredation on deer populations appears to be relative to moisture conditions and rodent levels (Dood 1978, Pyrah 1979). Dood's work in the Missouri River breaks indicated that fawn mortality was related to habitat use in the summer months. When precipitation was adequate to keep forbs green, does and their fawns used open habitat types. When moisture was inadequate, forbs dried up and does moved with their fawns into heavy timber types to use browse. Coyote depredation on fawns was higher when fawns were in the open types in all cases. Work by Pyrah showed that deer mortality from coyote depredation was less in two very severe winters as opposed to two normal or open winters. He correlated the lighter mortality in the severe winters with high-small mammal populations versus greater mortality in normal winters with low-small mammal populations. Coyotes preyed heavily on the small mammals and less so on the deer.

Inability to predict adequate moisture levels or rodent populations which affect coyote depredation on deer makes it difficult to predict the level or extent of depredation in any given year.

Continuation of present forage allocations would maintain lower than desired levels for wildlife habitat quality. Competition between wildlife and livestock for security cover and choice feeding sites would continue at present leve1s. Mackie (1970) observed that numbers and management of livestock should be considered on the basis of forage available on primary range areas rather than on the entire area. Livestock would be allocated forage on the basis of the entire area under this alternative. An examination of the 1952-53 range survey summary for the refuge revealed that wildlife are presently primarily allocated forage on Class VIII lands which are unsuitable for livestock use and suitable only for watershed, recreation and wildlife values. The forage on the best areas was allocated almost solely to livestock.

Forage allocations would continue to be dominantly in favor of livestock. A slow upward trend in condition would occur over about 75 percent of the refuge. This trend would continue and would be expected to raise range conditions to excellent on 20 percent of the grazed portion of the refuge by the year 2000 (compared to the present level of 18 percent). Some range deterioration would continue as a result of overstocking on some allotments, especially in the Big Dry Arm portion of the refuge. About 10 percent of the grazed portion of the refuge would be in fair to poor condition by the year 2000 as opposed to the 
present figure of about 8 percent. Continued over-grazing of those allotments in deteriorated condition could compound the situation for the entire allotment as livestock are forced to range farther from preferred range to find forage. Those allotments constitute a minority on a refuge-wide basis, however, and the overall range trend would continue to be slightly upward. Range objectives would not be met under this alternative.

The slow upward trend for the refuge as a whole would mean that additional AUMs would be available for livestock or wildlife use (minimum of 1000 AUMs by the year 2000).

Forage allocations to livestock would continue to depress habitat values for wildlife. Habitat values for wildlife would stay at or near present levels. There would be continued heavy use of range areas by livestock near water and on level to moderately sloping terrain. Use of primary wildlife areas by livestock would be heavier than desirable in some locations near dependable water. Lack of water in other areas would minimize all livestock use. The interspersion effect thus created would have beneficial impacts on some species of wildlife. Birds of open areas, such as prairie horned larks, lark buntings and several species of shorebirds, would benefit from livestock grazing effects. Prairie dogs and animals closely associated with prairie dog towns would benefit because localized disturbances such as overgrazing, which originally allowed establishment of the towns, would continue.

Seasons of use would continue to detract from overall range improvement potential. Several allotments have year-long grazing or early spring use authorized on a recurring basis. This type of grazing is not conducive to range improvement because the same localized areas are continuously subjected to heavy use with deterioration of plant and soil resources resulting.

No new range developments which would significantly affect wildlife and wildife habitat are proposed under this alternative. However, maintenance of some existing range facilities would have adverse impacts on wildlife habitat. Several improvements such as ponds in hardwood draws or breaks are presently located in primary wildlife habitat. Continued maintenance of these sites in important wildlife areas might increase opportunities for game-livestock competition. Mackie (1970) felt that control of water associated with primary cattle range could serve as a tool to provide better livestock distribution and lessen opportunities for game-livestock competition. He recommended no water developments on terminal portions of larger ridges or on smaller ridges where the area available for livestock is limited. This would lower the likelihood of game-livestock competition on important wildlife range.

The retention of private cabin sites and developed recreation areas would continue to exclude a limited amount of land from use as wildlife habitat and result in attendant loss of wildlife populations that would otherwise be associated with such habitat.

\section{RECREATION AND CULTURAL RESOURCES}

Generally, this alternative would contribute the least toward 
meeting national and regional recreation requirements and needs identified in the Nationwide Outdoor Recreation Plan (Bureau of Outdoor Recreation 1973) and Montana Statewide Outdoor Recreation. Plan (Montana Department of Fish and Game 1978). It also would accomplish little in terms of meeting recreation objectives established for CMR.

Present forage allocations would provide for undesirable aesthetic qualities in several allotments which have a considerable portion of deteriorated range. Most of these allotments are found in the Big Dry Arm which receives a considerable amount of recreational use during the grazing season when poor range conditions are most obvious.

Maintenance of the No Action alternative would provide ample viewing opportunities of prairie dogs and other species associated with poor or fair range conditions. Some increases in visitation are anticipated from minor improvements in interpretive facilities.

Since there would be only limited development or expansion of existing recreation areas, concentrated public use would continue in the vicinity of major recreation areas, especially at COE sites near Fort Peck and along the Big Dry Arm segment of the reservoir and between Fred Robinson Bridge and Seven Mile Creek on the west.

Impacts of public use on lands adjacent to the refuge would be similar to those on the refuge where comparable conditions and facilities occur. Most roads would remain unusable in bad weather and nonwildlife-oriented uses would predominate.

Reservoir water level fluctuations "would continue to periodically inundate the headwaters area, causing alterations to wildlife habitat and associated wildlife-related recreation opportunities. Some historic buildings and archeological/paleontological sites would be lost or remain unidentified. A few of the more significant sites would likely be nominated to the National Register of Historic Places.

\section{SOCIOECONOMICS}

As mentioned previously, there are present1y 60,108 federal AUMs permitted on the refuge; 3584 of these are in a nonuse status. Additional AUMs are utilized on state and private lands located within the boundaries of the refuge and amount to about 20 percent of the federal AUMs permitted by FWS. The number of FWS permitted AUMs would remain the same for 1985 and 2000. Because this alternative does not affect the number of future AUMs on the refuge, no direct or indirect economic effects would occur due to grazing. This alternative would provide little or no impacts to operators who graze livestock on CMR. It would provide for continuance of the lifestyles to which they are accustomed and would result in minimal new governmental interference with their operations.

In 1978 recreation visitor days totaled 357,000 (Table 12). Changes attributable to this alternative would be the difference between the 1978 figures and the estimate for 1985 and 2000. The direct economic effects are estimated to be $\$ 132,100$ between $1978-85$ and $\$ 112,200$ between 1986-2000. Present value of these direct effects is $\$ 677,800$. The figures are not adjusted for any anticipated price level changes. 
Indirect economic effects of an additional 21 man-years of employment and $\$ 153,900$ in income would result from an increase in visitation during 1978-85. Likewise, an additional 15.5 man-years and $\$ 117,700$ in income would result from an increase in visitation between 1986 and 2000.

Table 12 summarizes the noneconomic effects which would result from implementation of the No Action alternative. A detailed economics methodology is presented in Appendix 13. 
Table 12. Noneconomic effects, No Action alternative, Charles M. Russell National Wildlife Refuge, Montana.

\begin{tabular}{|c|c|c|c|}
\hline & $\begin{array}{l}\text { Present } \\
\text { situation }\end{array}$ & & tion \\
\hline & (1978) & 1985 & 2000 \\
\hline Habitat quality니 & & & \\
\hline Sharp-tailed grouse & 4.6 & 4.6 & 4.7 \\
\hline Mule deer & 5.6 & 5.6 & 5.8 \\
\hline Pronghorns & 5.2 & 5.2 & 5.3 \\
\hline White-tailed deer & 5.4 & 5.4 & 5.6 \\
\hline E1k & 6.0 & 6.0 & 6.2 \\
\hline Waterfowl & 3.4 & 3.4 & 3.4 \\
\hline Development & & & \\
\hline Burn (acres) & 0 & 0 & 0 \\
\hline Plant trees (acres) & 0 & 0 & 0 \\
\hline Plant shrubs (acres) & 0 & 0 & 0 \\
\hline Soil ripping (acres) & 0 & 0 & 0 \\
\hline Ponds (acres) & 0 & 0 & 0 \\
\hline Fences (miles) & & & \\
\hline Exclosure 21 & 0 & 0 & 0 \\
\hline Boundary (aprx.) & 50 & 56 & 56 \\
\hline Interior & Unknown & 0 & 0 \\
\hline Water projects (No.) & & & \\
\hline Ponds (aprx.) & 150 & 150 & 150 \\
\hline Troughs & 13 & 13 & 13 \\
\hline Springs & 0 & 0 & 0 \\
\hline Visitor days & & & \\
\hline FWS & 64,000 & 67,000 & 68,000 \\
\hline Other & 293,000 & 326,000 & 356,000 \\
\hline Total & 357,000 & 393,000 & 424,000 \\
\hline Forage (AUMs) & & & \\
\hline Wildlife & 50,000 & 50,000 & 51,000 \\
\hline Livestock (active) 3/ & 56,524 & 56,524 & 56,524 \\
\hline Total & 106,524 & 106,524 & 107,524 \\
\hline Range condition (\%) & & & \\
\hline Poor & 1 & 1 & 1 \\
\hline Fair & 7 & 8 & 10 \\
\hline Good & 74 & 72 & 69 \\
\hline Excellent & 18 & 19 & 20 \\
\hline
\end{tabular}

1/ $0-2.5=$ poor, $2.6-5.0=$ fair, $5.1-7.5=\operatorname{good}$ and $7.6-10.0=$ excellent.

2/ A precise estimate of acres enclosed/mile of fence is not provided due to presently undetermined topography and shape of exclosure. A general rule of thumb is 40 acres enclosed per mile of fence.

3/ These figures represent active AUMs; 3584 AUMs are inactive; thus the total is 60,108 AUMs. 


\section{ALTERNATIVE B}

\section{(PROPOSED ACTION)}

\section{SOILS-WATERSHED}

Fire management practices would result in the opening of some coniferous forest stands to increase grass, forb and shrub levels to retard runoff and soil loss. Eichhorn and Watts (1974) observed that the evergreen litter and tree overstory of unburned sites are less effective in reducing erosion than nontree vegetation on burned sites. Grazing reductions, planting and exclosures would provide more residual cover and shrub communities which would also retard runoff and decrease erosion.

Areas on level to moderate slopes and within one mile of water would generally receive light to moderate use by livestock because of reduced stocking levels. More fragile areas such as shale, breaks and badlands range sites and steep terrain with over 20 percent slope gradient would receive little or no livestock grazing. Any use on these areas would tend to increase soil or parent material loss because of vegetation cover removal and livestock movements ( $W$. Larsen personal communication). Soil erosion on these fragile areas would be reduced and essentially confined to geologic processes. Increased litter cover on areas considered to be principal livestock range would be expected.

Bare soils on the most productive range sites, such as clayey, silty, sandy and overflow, would be lowered from the present average range of 20-42 percent to 15-25 percent by 1985. This would lower present rates of erosion by allowing increased water infiltration into the soil and reducing amounts of soil exposed to the elements. Overland runoff and sedimentation would be lowered and water quality would be enhanced.

Several thousand acres of panspots and dense clay sites exist on CMR. These areas are salt affected, relatively water impermeable and characterized by sparse vegetation. Ripping of as much as 10,000 acres of these panspots and dense clay range sites would improve soil properties in terms of texture, soil nutrients and water infiltration on the treated areas, thereby enhancing long term productivity of these areas. A two-to fivefold increase in vegetative biomass is possible by ripping on favorable sites (C. Clark personal communication). Wight et al. (1978) reported an increase in herbage production of 165 percent with 10 percent more plant-available soil water on panspots sites in southeast Montana following ripping of the soil surface. J. Rogers (personal communication) stated similar results are normally obtained through breaking the surface of panspots by ripping or furrowing. These improvements are expected to occur on the 10,000 acres proposed for ripping. The perched water table of ten present on these sites would be eliminated; water would be allowed to percolate through the soil profile and would help flush out accumulated salts; increased quantities of water would be available for plant uptake. Greater site productivity would occur as a result. Ripping this acreage would increase the carrying capacity of 
the refuge by a minimum of 750 AUMs. Lower sediment loads and higher water quality would occur from increased plant and litter cover levels. There may be short term effects of increased erosion on treated areas until vegetation is re-established.

Boundary and interior fences would help improve soils and watershed conditions within several allotments through control of livestock. This would help improve range conditions and ultimately soils and watershed values through increased plant and litter cover. This would benefit wildlife habitat. No significant detrimental impacts are expected to occur to wildlife as a result of fence construction.

A water facility proposed for the Kill Woman allotment and approved for construction by the Soil Conservation Service, would help eliminate a head-cutting problem in one drainage through control of runoff. Other water facilities planned would result in only minor enhancement of soils and watershed conditions.

\section{WILDLIFE HABITAT-RANGE RESOURCES}

Reintroduction of black-footed ferrets and peregrine falcons would provide additional wildlife diversity on CMR and help perpetuate these two species. Reintroduction of black-footed ferrets would involve maintenance of prairie dog towns. These areas would remain in poor range condition, but would provide desirable wildlife habitat for several wildlife species. Prairie dog expansion onto adjacent landowners' lands might necessitate control measures. Other management decisions concerning prairie dog control would be made upon completion of the present prairie dog study on CMR.

Lack of residual vegetation for cover and food is limiting to several species of wildlife. Reducing grazing 33 percent would increase residual vegetation to provide nesting and hiding cover and forage.

Reduction or elimination of livestock AUMs would occur where competition between bighorn sheep and livestock occur. There would be increased residual cover which would provide more forage for bighorn sheep. Eichhorn and Watts (1976) assessed livestock-bighorn sheep competition in the Two Calf drainage, indicating that limited winter habitat and competition with livestock have limited the success of the sheep reintroductions there. Bighorn sheep would increase in number as a result of reduced competition with livestock.

It is expected that 70 percent of potentially suitable sites would have 8-10 inches of residual cover by 1985. This would provide sharptailed grouse with the cover they require for nesting (Christensen 1971, Sisson 1976) and would increase spring bird populations from approximately 5 birds $/ \mathrm{mi}^{2}$ to a projected level of $30 \mathrm{birds} / \mathrm{mi}^{2}$ on suitable habitat (Fish and Wildlife Service 1978). This would also provide improved shelter and protection from predation for all ground nesting birds, improved night roosting areas for sharp-tailed grouse, improved insect food sources for bluebirds, more cover for small rodents and porcupines and a greater forage supply for mule deer, elk and pronghorns.

Approximately 30 percent of the suitable areas would not attain 
this level of cover by the year 2000 because areas on level to moderate slopes and within one mile of water would receive light to moderate use by livestock. These areas would have less cover and thereby benefit species such as mountain plovers, burrowing owls, ferruginous hawks, prairie horned larks and prairie dogs (Bureau of Land Management 1979).

Changes from sheep to cattle and changes in grazing intensities and seasons of use would increase forbs for pronghorns and mule deer by 3035 percent. According to Mackie (1970) forbs constitute an important component in the summer and fall diet of mule deer in the Missouri River breaks. Cole (1956) made similar statements for pronghorns.

The response of small mammals to increased amounts of cover and available forage would be varied. Voles, which rely heavily on grass for food and cover, would increase while deer mice, which use plant seeds to a greater extent for food and are better adapted to sparsely vegetated areas, would probably decrease (Black 1968, R. Moore personal communication).

Prescription grazing would maintain stands of big and silver sage at present levels; different intensities of livestock use would modify plant composition to favor sagebrush (heavy use in early spring) or grasses and forbs (light or no use). This would provide enhanced fawning areas and winter cover for resident pronghorns (Bayless 1969). Different treatments would change habitat conditions to meet particular wildlife needs in terms of food or cover at critical periods of the year. Large numbers of pronghorns move into the breaks and CMR during severe winters. When these conditions occur, pronghorns need the best possible habitat conditions to survive. Improved habitat conditions under the Proposed Action would enhance survival of the herds using the refuge at these critical periods.

Prodgers (1979) stated:

"Shrub dominated communities afford some of the best wildlife habitat on the CMR NWR by providing food, cover and perches. With a few exceptions (such as rabbitbrush, sagebrush, and greasewood), shrubs are found on sites with above average moisture and low or normal soil salt levels...

"Shrubs were much more abundant on the Refuge prior to the great drought of the $1930^{\prime} \mathrm{s}$. Murie (1937) observed that as much as $95 \%$ of the buffaloberry was dead in 1935, and severe drought lasted several years after that. When attempting to establish more shrubs on the Refuge, the Manager should recognize that success will be nil in drought years, though shrubs established in prior years may persist, perhaps as a function of length of establishment...

"If shrubs are established on suitable sites, they can be expected to reproduce naturally within several years and thus colonize suitable adjacent areas. However, most shrubs are palatable to livestock and grazing could endanger not only reproduction, but survival itself. Seeded or planted areas should be pro- 
tected from grazing until desired shrub abundance is achieved, and thereafter the effects of grazing should be carefully monitored..."

Prescribed burning on approximately 7700 acres, planting of suitable shrubs on approximately 500 acres and construction of livestock exclosures in key hardwood draws would improve the all-important shrub communities by 2000. This would provide an increased food base for deer and upland game birds as well as cover for deer, sharp-tailed grouse, and several small birds and mammals.

Seventy percent of the suitable hardwood draws would have the desired shrubs by the year 2000. Because shrub responses are slower than the effects of reduced grazing upon residual cover levels, continual improvement in shrub quality would occur for another 40-50 years.

Eichhorn and Watts (1974) found that burned areas in the Missouri breaks produced substantially more forbs and shrubs than unburned control sites. Those shrubs which could be enhanced on the refuge by burning include rose, chokecherry, snowberry, buffaloberry, serviceberry and skunkbrush sumac (Fish and Wildlife Service 1978). Mule deer, sharp-tailed grouse, pronghorns and white-tailed deer would all benefit from an increased food base. There would also be summer cover for mule deer, sharp-tailed grouse, song birds, porcupines, bobcats and elk. Winter roosting areas for sharp-tailed grouse would be enhanced as would nesting sites for passerines and winter use areas for mule deer and bobcats. Habitat quality for sharp-tailed grouse would increase from fair to good ( 56 percent increase in habitat quality) by the year 2000 and mule deer habitat in hardwood draws would increase in quality by 28 percent for the same period (Appendix 14).

The few riparian zones proposed to be fenced would improve substantially. Unfenced riparian zones would receive lighter overall use and re-establish riparian habitat more gradually than the fenced areas. Good habitat would be achieved by the year 2000 on these unfenced riparian areas, which include Slippery Ann Creek, Rock Creek (west), Timber Creek (east) and Fourchette, Big Dry, Squaw and Hell creeks. Although riparian areas and ponds would continue to sustain a disproportionate share of livestock grazing, reductions in AUMs under this option would substantially reduce pressures on areas that are overutilized. To restore and maintain vegetative quality and vigor to all important riparian areas and ponds, livestock grazing would have to be eliminated in the entire allotment or the areas completely fenced (Hormay 1976). Most of the upland ponds would still have limited value as waterfowl production areas.

Bottoms along the Missouri and Musselshell rivers would continue to remain fenced and unavailable to livestock except on a prescription basis. This would preserve the riparian community and maintain the overall wildlife habitat for white-tailed deer in good condition by 2000.

Phasing-out of the cooperative farming program would allow the bottoms along the Missouri River to revert to a natural riparian community. Mule deer habitat in the big sage-greasewood-grassland, 
ponderosa pine-juniper and grassland deciduous shrub types would be improved 34 percent by the year 2000 as a result of increased forb and shrub levels (Appendix 14). This would mean increasing the habitat's ability to support an over-wintering population of from 6-10 deer $/ \mathrm{mi}^{2}$ (Fish and Wildlife Service 1978). Elk populations would not change significantly as a result of the Proposed Action. Elk use large areas off the refuge which contain essential habitat components beyond CMR's control.

Overall habitat quality would increase 16-105 percent depending on wildlife species evaluated (Appendix 14). Wildlife objectives would be met. The reduction in grazing to accomplish this increase in habitat quality might result in lowering of habitat quality on private lands if landowners increase stocking rates on these lands to compensate for the loss of AUMs on the refuge.

Increasing vegetation along continuous and intermittent streams would reduce siltation and stabilize stream flows which could benefit the reservoir fishery.

Impacts from predator and animal control would be the same as the No Action alternative.

Range communities would improve substantially from the proposed forage allocations. Approximately 25 percent of the grazed portions of the refuge would be in excellent condition by 1990 and 35 percent in excellent condition by the year 2000. Fair condition range would be reduced from the present level of 7 percent to an estimated 3 or 4 percent because of reductions in livestock on overgrazed allotments, particularly in the Big Dry Arm area. Grazed portions of the refuge in poor ecological condition (about 1.1 percent) would not change appreciably. These areas are most commonly associated with prairie dog towns or are flood plains which are periodically disturbed by floods or ice jams. Owensby et al. (1973) found that little change occurs on poor condition range after 10 years. They estimated it would take 40 years for overgrazed range to attain excellent condition under complete rest in a precipitation zone of 25 inches annually. It is therefore unlikely that the poor condition range on the refuge would be significantly enhanced by the year 2000 .

Although overutilized areas would be reduced under this alternative, some of these sites would be present as long as cattle are grazed on a seasonal, continuous or year-long basis. Areas with no livestock grazing, or those having rotation systems or prescription grazing would not have significant distribution problems because of a periodic rest cycle or total rest to facilitate vegetal response.

The proposed livestock reductions would help limit most livestock grazing to areas with a slope gradient of less than 20 percent and within one mile of water. Mackie (1970) observed that 90 percent of livestock use in the Missouri breaks was within one mile of water and over 80 percent occurred on slopes of less than 10 degrees gradient. Allocations of forage to livestock were made taking these factors and soils limitations into consideration to eliminate range overuse by livestock on primary ranges (Appendix 15). This would provide a greater amount of forage per animal on these primary livestock ranges and reduce 
the need for them to range further for forage.

Light stocking levels proposed by this action would have the effect of maintaining productivity and a diversity of habitat conditions. Van Poollen and Lacey (1979) reviewed pertinent literature with respect to grazing systems and intensities on western ranges:

"Mean annual herbage production increased by 13 percent when grazing systems were implemented at moderate stocking intensities. Increases were greater (35 and 27 percent) when continuous livestock use was reduced from heavy to moderate and moderate to light, respectively. This indicates that adjustments in livestock numbers have a greater effect on herbage production than do grazing systems."

Grazing systems evaluated and compared with continuous use included rotation, deferred, rest rotation and deferred rotation systems under moderate stocking levels (40-60 percent utilization of forage).

Klipple and Costello (1960) in a 13-year study provided an appropriate description of the effects of light grazing by livestock on vegetation.

"Light grazing, as defined in this study, was characterized by distinct patches of grazed vegetation surrounded by areas of almost ungrazed vegetation. Grazed areas had as much as 50 percent of the current growth removed. Ungrazed plants of the highly palatable species were easily found, and conspicuous stubble remained on the grazed plants. Plants of low palatability, such as three-awns, broom snakeweed, rubber rabbitbrush, and slender bush eriogonum, seldom showed grazing use."

This type of grazing by domestic livestock would provide the diversity of habitat conditions needed to achieve desired wildlife populations and diversity of species. Range objectives would be achieved with this alternative.

Klipple and Costello's description of the effects of light grazing coincides with a description of the effects of bison grazing on the National Bison Range, Montana (R. Brown personal communication). Based on this, forage allocation under this alternative could approximate grazing by bison.

Little or no livestock grazing would occur on sites more distant from water or on steeper terrain. Hardwood shrubs on these more remote areas would be able to complete their growth cycle without being affected by livestock trampling and grazing. Resultant livestock-wildlife stocking levels would tend to be somewhat in line with Mackie's (1970) management considerations for a joint use range situation, where livestock are favored on the more level ranges close to water and wildlife are favored on steeper, more inaccessible terrain having good security 
cover or in areas more remote from water.

The Proposed Action alternative would tend to produce a diversity of habitat conditions. The desired vegetative components of residual cover and enhanced shrub production would be produced on a larger percentage of potentially suitable sites, but use patterns by livestock would ensure maintenance of habitat conditions for wildlife species having less stringent residual cover and shrub requirements. The result of grazing used as a management tool would be to maintain or alter habitat to benefit a particular wildlife species. Grazing at the proposed levels would maintain vegetative productivity and vigor, but would also provide for the necessary residual cover to meet requirements of ground nesting birds and small mammal species. Forage equivalent to approximately 69,000 AUMs would be made available for wildlife for consumption as food or for cover requirements by 1985 . The refuge would be managed under the philosophy that light livestock grazing levels are not detrimental to wildlife populations (Appendix 16).

Lower grazing pressure by livestock would provide enhancement of vegetative resources in some deteriorated areas. An increase of about 5000 AUMs of forage should be realized by the year 2000 from the improved range conditions and would be available to wildlife.

Mackie (1970) felt that the onset of livestock grazing in the Missouri breaks should be delayed until mid-May when plant growth is more advanced. Smith (1979) supported Mackie's discussion in regard to plant responses to grazing and range readiness. Some disturbance with wildlife nesting and fawning activities could be expected by allowing onset of livestock grazing in mid-May. Under the light livestock use proposed by this alternative, these disturbances are not expected to be significant. If conflicts do occur, adjustments in grazing seasons will be made as required to minimize conflicts with wildlife. Fall and winter livestock use on range grazed by elk and deer also increases livestock-wildlife competition for forage. Such use has been identified as a problem in several allotments. Implementing later turn-in and earlier turn-out dates for livestock would mean a better opportunity to enhance habitat conditions for wildlife by allowing a higher state of range readiness in the spring before onset of livestock grazing and less competition for forage between livestock and wildlife on winter ranges.

Reduced grazing levels may have the tendency to open sagebrush stands and reduce canopy cover of sagebrush because grasses in the stand would receive less grazing pressure. Grasses have root systems better adapted to catching infiltrating water and under normal livestock grazing pressures, grasses are selectively taken in preference to the relatively unpalatable sage. Continuous grazing would eventually result in reduced levels of grass cover and increased sage cover because sage is not commonly browsed by livestock. Under the Proposed Action, prescription grazing would be utilized to help maintain sagebrush communities if they begin to decline to benefit such species as mule deer, pronghorns and sage grouse.

Ripping of a maximum of 10,000 acres of dense clay and panspots would result in higher vegetative production on these areas with increased quantity and quality of residual cover for wildlife. Without 
the proposed mechanical treatments, it is unlikely that such sites will ever be highly productive from a vegetative and wildlife habitat standpoint. Several existing reservoirs would be enlarged and rehabilitated. This would enhance conditions for shorebirds and waterfowl. Some new fences would be constructed along the refuge boundary to control livestock and help attain desired vegetative cover levels. Some minor riparian areas across the refuge lack good shrub communities; construction of a minimum of six miles of fence would help alleviate this situation. Habitat quality would be expected to increase from fair to good as a result of this and other proposed treatments.

New recreation areas and related developments would be prohibited near sensitive wildlife habitat and incompatible activities would be curtailed during critical nesting and breeding seasons. Most recreational development would occur at areas already disturbed by facilities.

\section{RECREATION AND CULTURAL RESOURCES}

Compared to the others, this alternative would contribute an intermediate amount toward meeting national and regional recreation requirements and needs identified in the Nationwide Outdoor Recreation Plan (Bureau of Outdoor Recreation 1973) and Montana Statewide Comprehensive Outdoor Recreation Plan (Montana Department of Fish and Game 1978). Recreation objectives identified for CMR would be satisfied. Introduction of endangered or unique species such as peregrine falcons, black-footed ferrets, swift fox and bighorn sheep would increase the diversity of animals available for wildlife-oriented recreation. The rare occurrence of these species and the equally rare opportunities to view them anywhere else would provide a once-in-alifetime opportunity for many visitors. Introduction of peregrine falcons would necessitate restriction of human disturbance during the breeding season (Snow 1972).

Improvement of habitat would increase the numbers of wildlife that would be observed or taken. Any stabilization of water levels in Fort Peck Reservoir that may be possible would enhance recreation, wildlife and fishery values and retain the approximate 21 -mile reach of the Missouri River from the Fred Robinson Bridge to headwaters of Fort Peck Reservoir in a free-flowing condition. This would be accomplished, as conditions permit, without major impacts on flood control, hydropower generation, water supply, recreation or fish and wildlife.

In addition to the cultural surveys that would be undertaken, other benefits would accrue due to the provision of an historic tour route and interpretation of numerous historical, archeological and paleontological features throughout the refuge. Sites eligible for inclusion on the National Register of Historic Places would be identified and areas having significant values would be designated as special districts or natural landmarks.

The proposed forage allocations would provide enhanced range conditions on a refuge-wide basis. This would enhance the aesthetic quality of the refuge and provide a higher quality recreational experience as well as a greater opportunity to recreate. Ripping of dense 
clay and panspots range sites would have an adverse effect on visual resources for a minimum of 3-5 years. Prescribed burning would result in a lowering of visual quality for 1-5 years.

The water pipeline and troughs that would be constructed about one mile from the present wildlife tour route on the west end of the refuge would help attract livestock concentrations away from the area and improve wildlife viewing potentials.

Increases in visitation would occur due to provision of various interpretive facilities, including visitor contact stations, a sailpowerboat tour route, backcountry-nature trails and interpretive programs and displays. These uses would enable the public to acquire a better understanding of and appreciation for wildlife and related resources. The only new area to be developed would be at Fourchette Bay which would provide access and facilities for recreationists on the northwest end of the refuge. About half the additional use associated with this site is expected to be wildlife and wildlands-oriented. There would be a small increase in vehicular travel over roads leading into the refuge across BLM land and some additional use of BLM lands for recreation. Improving roads would provide better access for fishermen, hunters and other recreationists.

Establishing scattered access sites to the reservoir over a large area would more evenly distribute use, reducing congestion at some existing sites and improving the quality of the recreation experience.

Development and use of roads and permanent recreation facilities would reduce available wildlife habitat. Perry and Overly (1977) found that vehicular use of all roads in the Blue Mountains of Washington (main, secondary and primitive) had a significant detrimental effect on use by big game to a distance of one-half mile as compared to control plots where no roads were located. Proper planning of road systems on the refuge would serve to minimize potentially detrimental impacts to wildlife.

Proper planning of public use resulting from a management study of the Slippery Ann area would ensure a high quality recreation experience while minimizing management problems and impacts on wildlife. By permitting landing of aircraft only at specified locations on the refuge, there would be no significant conflicts with wildlife or recreationists.

\section{SOCIOECONOMICS}

Grazing would be reduced from 60,108 AUMs to 40,482 AUMs by 1985 . This represents a decrease of 19,625 AUMs or about 33 percent. Between 1985-2000, grazing activities would be increased slightly from 40,482 to 40,628 AUMs. This increase would result from proposed land acquisitions on CMR. The self-furnished AUMs on these lands would be converted to federal AUMs as the tracts are acquired. The direct effect of the AUM reductions from $1978-85$ is estimated at a negative $\$ 134,000$ (present value). This direct effect would be sustained almost entirely by permittees who use the refuge. The possible consequences of implementing the Proposed Action upon individual permittees who graze livestock on the refuge are shown in Appendix 10. 
The Proposed Action is expected to have high adverse impacts on six livestock operators. These impacts may result in the operators being forced out of business. Factors used in the evaluation of adverse impacts included known herd size and percentage of total forage requirements provided by CMR. Other factors as permittee indebtedness, other agricultural holdings and nonfarm income are unique to the individual permittees and privileged information. Since no data were available on these items they could not be addressed in this analysis. These unknown factors could result in a greater number of operators suffering high adverse impacts and being forced out of business than anticipated in this analysis. This loss of income is insignificant on a regional basis, representing only 0.5 percent of the total livestock earnings. Total income in this area in 1975 was $\$ 155,922,000$.

Table 13 shows the projected levels of annual visitation for the years 1985 and 2000; exisiting conditions for 1978 are shown to facilitate comparison. Direct economic effects of the increase in visitation would be $\$ 152,500$ for $1978-85$ and $\$ 217,000$ for 1986-2000. The present value of these direct economic effects is $\$ 1,017,000$. There would be an increase of 22.5 man-years of employment and additional income of \$162,500 in the region during the period 1978-85 resulting from this action. The increases from 1986-2000 would be 16.0 man-years of employment and $\$ 129,900$ in total income.

Table 13 summarizes the noneconomic effects which would result from implementation of the Proposed Action alternative. 
Table 13. Noneconomic effects, Proposed Action alternative, Charles M. Russel1 National Wildlife Refuge, Montana.

\begin{tabular}{|c|c|c|c|}
\hline & $\begin{array}{c}\text { Present } \\
\text { situation } \\
(1978) \\
\end{array}$ & $\begin{array}{l}\text { Proposed } \\
1985 \\
\end{array}$ & $\begin{array}{r}\text { Action } \\
2000 \\
\end{array}$ \\
\hline \multicolumn{4}{|l|}{ Habitat quality $1 /$} \\
\hline Sharp-tailed grouse & 4.6 & 5.8 & 7.2 \\
\hline Mule deer & 5.6 & 6.8 & 7.2 \\
\hline Pronghorns & 5.2 & 6.5 & 7.4 \\
\hline White-tailed deer & 5.4 & 6.5 & 7.4 \\
\hline E1k & 6.0 & 7.0 & 7.6 \\
\hline Waterfowl & 3.4 & 4.2 & 7.0 \\
\hline \multicolumn{4}{|l|}{ Development } \\
\hline Burn (acres) & 0 & 1900 & 7700 \\
\hline Plant trees (acres) & 0 & 0 & 0 \\
\hline Plant shrubs (acres) & 0 & 100 & 500 \\
\hline Soil ripping (acres) & 0 & 0 & 10,000 \\
\hline Ponds (acres) & 0 & 0 & 0 \\
\hline \multicolumn{4}{|l|}{ Fences (miles), } \\
\hline Exclosure 2 & 0 & 2 & 6 \\
\hline Boundary (aprx.) & 50 & 91 & 97 \\
\hline Interior & Unknown & 21 & 21 \\
\hline \multicolumn{4}{|l|}{ Water projects (No.) } \\
\hline Ponds (aprx.) & 150 & 153 & 153 \\
\hline Troughs & 13 & 23 & 23 \\
\hline Springs & 0 & 0 & 0 \\
\hline \multicolumn{4}{|l|}{ Visitor days } \\
\hline FWS & 64,000 & 70,000 & 73,000 \\
\hline Other & 293,000 & 326,000 & 360,000 \\
\hline Tota1 & 357,000 & 396,000 & 433,000 \\
\hline \multicolumn{4}{|l|}{ Forage (AUMs) } \\
\hline Wildlife & 50,000 & 69,000 & 74,000 \\
\hline Livestock (active) & $56,524 \underline{3} /$ & 40,482 & 40,628 \\
\hline Tota1 & 106,524 & 109,482 & 114,628 \\
\hline \multicolumn{4}{|l|}{ Range condition (\%) } \\
\hline Poor & 1 & 1 & 1 \\
\hline Fair & 7 & 7 & 4 \\
\hline Good & 74 & 67 & 60 \\
\hline Excellent & 18 & 25 & 35 \\
\hline
\end{tabular}

1/ $0-2.5=$ poor, $2.6-5.0=$ fair, $5.1-7.5=\operatorname{good}$ and $7.6-10.0=$ excellent.

2/ A precise estimate of acres enclosed/mile of fence is not provided due to presently undetermined topography and shape of exclosure. A general rule of thumb is 40 acres enclosed per mile of fence.

3/ This figure represents active AUMs; 3584 AUMs are inactive totaling 60,108 AUMs. 


\section{ALTERNATIVE C}

\section{(INTENSIVE WILDLIFE MANAGEMENT)}

\section{SOILS-WATERSHED}

Fire management practices would result in the opening of some coniferous forest stands to increase grass, forb and shrub levels to retard runoff and soil loss. Eichhorn and Watts (1974) observed that the evergreen litter and tree overstory of unburned sites are less effective in reducing erosion than nontree vegetation on burned sites. Planting and exclosures would provide more residual cover and shrub communities which would also retard runoff and erosion.

Forage allocations under this alterative would considerably enhance soils and watershed. Livestock grazing would total about 27,000-30,000 AUMs and would remove considerably less forage compared to present levels. This would provide more litter cover on traditional primary livestock areas. Water infiltration into the soil would be higher, soil compaction and runoff lower and bare soil exposed to wind erosion considerably less. These adverse impacts are cumulative over the years and continue from year to year, although they may be lessened by rest from grazing.

Marginal sites that are highly fragile such as thin breaks, badlands and shale would receive little or no use and soil erosion would be minimized. Any use on these areas by livestock tends to increase soil or parent material loss because of vegetation cover removal and livestock movements ( $W$. Larsen personal communication).

A boundary fence would control all livestock movements within the refuge and improve range conditions and therefore soils and watershed.

Ripping of all suitable panspots and dense clay range sites outside proposed or designated wilderness areas would improve watershed quality and reduce soil erosion through increased plant and litter cover. Ripping would allow greater water infiltration into the soil, making it available for plant uptake. This increased water supply would enhance site productivity and lower amounts of exposed soil.

Soil productivity would be considerably enhanced because of reductions in rates of soil erosion and soil ripping operations. Increased plant and litter cover resulting from improved range conditions and soil ripping operations would provide nearly optimal watershed conditions for the whole refuge.

\section{WILDLIFE HABITAT-RANGE RESOURCES}

The general grazing pattern proposed in this alternative would probably keep prairie dogs and their associated species at their present level (C. Knowles personal communication). Knowles inferred that maintenance and expansion of prairie dog populations is dependent upon mancaused disturbances such as livestock grazing, reservoirs, holding corrals or wells. This is supported by McEneaney and Jensen (1974) and BLM (1979), who noted that the presence of prairie dogs is most likely a 
symptom, rather than a cause, of deteriorating range. Prescription grazing would be employed as necessary to manipulate habitat for these species.

Since grazing would generally be on a prescription basis, bighorn sheep and cattle conflicts would be eliminated. There would be no conflicts between buffalo and bighorn sheep since they would occupy different habitat.

Lack of residual vegetation for cover and food is limiting to several species of wildlife. Using prescription grazing as a tool would increase residual vegetation to provide nesting and hiding cover and forage for wildlife.

The limited livestock grazing allowed would result in an increase of residual cover to 8-10 inches on 80-90 percent of the suitable sites by 1985. This would provide suitable nesting cover (Christenson 1971, Sisson 1976) for an optimum number of sharp-tailed grouse in the springtime $\left(30-35 / \mathrm{mi}^{2}\right)$. It would also benefit a wide range of species described under the Proposed Action alternative.

Eliminating livestock grazing except on a prescription basis would provide more forbs for pronghorns and mule deer and increase this aspect of habitat quality for both species by 30-45 percent (Appendix 14). According to Mackie (1970) forbs constitute an important component in the summer and fall diet of mule deer in the Missouri River breaks. Cole (1956) reported similar findings for pronghorns. Mackie (1970) also reported that forbs comprised an important component in diets of cattle during spring, summer and fall.

Increased grass and forb production in sagebrush communities would be expected under light grazing with a gradual "opening" of the stand as the shrubs mature and die. This would be detrimental to wintering populations of pronghorns, sage grouse and mule deer. However, prescription grazing by livestock early in the spring (April 15-June 15) would be employed for two or three years or longer as required to reverse any trend toward grass and forb dominance in a stand. Livestock would select the palatable grasses and forbs over sage, thus providing the sage with a competitive edge in succeeding years. Some lowering of wildlife habitat quality (residual cover levels) may occur in pastures subjected to livestock grazing in a given year.

Wildlife species such as chestnut-collared longspurs, prairie horned larks (Owens and Myres 1973) and mountain plovers (Smith 1940), which benefit from lower quality residual cover levels, could be detrimentally affected by this action. However, prescription grazing would be employed to provide habitat conditions to benefit these species.

Key shrubs are lacking for use as food as well as cover and perches. Prescribed burning on approximately 15,000 acres, planting of suitable shrubs on approximately 3000 acres, construction of temporary wildlife exclosures in key hardwood draws and prescription grazing would improve important shrub communities. Prescription grazing alone would probably not provide for sufficient response by shrubs within the desired time frame especially since shrubs are limited in distribution at present. The proposed planting and burning would provide for establishment of 
shrubs on a substantial portion of CMR. Eventual expansion through natural reseeding from the planted or burned areas would help meet objectives for wildlife in terms of shrub quantity and quality. Ninety percent of the potentially suitable hardwood draws would have desired shrub densities by the year 2000. Because shrub responses are slower than effects of reduced grazing upon residual cover levels, continual improvement in shrub quality would occur for another 40-50 years.

Several other species would benefit from burning and planting. They include sharp-tailed grouse (improved roosting cover, Sisson 1976), mountain bluebirds (grass and open areas, Balda 1975, Miller 1970) and porcupines (improved ground cover, Costello 1966). Prescribed burning combined with prescription grazing would improve sharp-tailed grouse and mule deer habitat to meet or exceed wildlife habitat objectives for these species before 2000.

Most of the river bottoms along the Missouri and Musselshell rivers are presently excluded from livestock use. They should be near their full potential by 1985 . It is estimated that 80 percent of potentially suitable areas in these drainages would be at or above desired levels for tree and shrub composition by 2000. Vegetation around stock watering reservoirs should have the 8-10 inches desired residual cover on 7580 percent of suitable areas by the year 2000. This alternative would provide the fastest response for recovery toward cIimax short of artifically reseeding affected areas and totally resting them.

T. Planz (personal communication) estimated that waterfowl production at UL Bend alone would be increased from 200 to 2000 birds with intensive management. No figures are available for the entire refuge but it would be expected that similar results could be achieved on a refuge-wide basis. Some sites would be slower to respond because of the present degree of dominance by increaser and invader plant species.

All smaller streams with adequate water sources should have substantially improved riparian zones. This would be assisted with temporary fences to exclude wildlife where necessary.

More intensive farming in conjunction with improved riparian areas would provide optimum food and cover levels for many species of wildlife. Mule and white-tailed deer, raccoons, sharp-tailed grouse, ringnecked pheasant, turkeys, mourning doves, waterfowl and most all other wildlife species would take advantage of these farm plantings to supplement their food supply. It is anticipated that elk would be drawn to these areas and reduce their use of adjacent private crops.

Extensive tree planting would provide maximum security cover and reduce displacement of elk from human and livestock disturbance. This tree planting would be done to improve habitat in Valley County where tree cover is presently considered to be inadequate.

Overall habitat quality could be expected to increase 25-165 percent over the 20-year period, depending upon the species evaluated (Appendix 14). Wildlife objectives would be met. The increase in habitat quality and capability to support wildlife which would occur as a result of reductions in livestock grazing may result in lowering of habitat quality on adjacent lands if private landowners increase stock- 
ing rates of their lands to compensate for loss of AUMs on the refuge.

Improving vegetation on continuous and intermittent streams would reduce siltation and stabilize stream flows. Establishment of spawning habitat on Fort Peck Reservoir could make fish reproduction possible. This could reduce the need for stocking operations and increase the fishery resource. Impacts from coyote and prairie dog control would be the same as the No Action alternative.

Livestock grazing would be based primarily upon known plant responses to grazing levels and seasons of use. Spring-summer use in alternate years would provide stimulation of vigor and production from grazing, with rest periods providing storage of food reserves by plants. Grazing in this manner would provide a significant degree of enhancement of climax plant species (Smith 1979). Smith (1979) and Hormay (1980) indicated that two years of rest following grazing is necessary for enhancement of vegetative cover on the refuge. The desired results to be achieved in terms of residual cover and habitat quality for wildife would determine the extent of deviation from the prescription grazing system described above. For example, several years of moderate to heavy grazing might be required to promote habitat conditions for some wildlife species.

Other site specific habitat treatments such as prescribed burning would improve those areas for species needing vegetative conditions other than climax. In most situations, approximately the same number of livestock would be assigned to a given allotment or pasture as are presently assigned. However, two years of total rest out of three as proposed by Smith (1979) would effectively reduce present annual livestock AUM levels by about two-thirds. Livestock grazing is currently conducted at moderate levels on a refuge-wide basis. Employing the above concepts refuge-wide would mean an initial reduction in federal AUMs to approximately 23,000 by 1985 . Grazing on state and private inholdings would remain at present levels. By the year 2000, all state and private inholdings would be acquired by exchange or purchase and converted from self-furnished to federal AUMs. These AUMs would then be changed to a prescription basis or retired. By the year 2000, a11 grazing would be on a prescription basis. Livestock levels would probably fluctuate between 27,000-30,000 AUMs. By itself, prescription grazing would not significantly enhance habitat quality over grazing levels in the Proposed Action. The proposed intensive treatments of planting, burning and ripping would be the primary contributing factors involved in improving wildlife habitat.

Approximately 87,500 AUMs would be allocated to wildlife for food and cover requirements by 1985 with about 107,000 AUMs available to wildlife by the year 2000 .

This pattern of grazing might eliminate use by small, family-owned ranching operations which depend heavily upon AUMs supplied by the refuge (Appendix 10). It would mean elimination of most allotments in their present form. Some larger operators would continue in a semblance of their former status. Livestock operations under this alternative would conceivably be run by 15-20 large ranches or corporations which are not highly dependent upon federal lands. Individuals, ranching 
operations or associations having a few to several hundred AUMs would possibly be eliminated in favor of large scale operations desiring to utilize a minimum of 1000 or more AUMs during the grazing season. It is estimated that approximately 13 operators would be forced out of business by this alternative (Appendix 10). Additional economic information is not available and economic consequences could be greater, as stated in the Proposed Action alternative. Range objectives would not be met under the Intensive Wildlife Management alternative.

Virtually all the desired areas on the refuge would approach excellent range condition by the year 2000. Poor and fair condition range would take substantially longer to reach excellent condition. Owensby et al. (1973) reported findings from a Kansas study where little improvement was noted on deteriorated ranges after 10 years following fencing. The authors estimated recovery time to excellent condition to be 40 years, even with complete rest and in a precipitation zone of 25 inches annually. Gradually, however, even this depleted range would be restored to its full potential if desired. Wildlife objectives might dictate that these areas be maintained at a lower range condition.

All existing grazing systems would be drastically affected by this new grazing program. The program would employ a type of grazing which would benefit soils, watershed and wildlife values.

Prescription grazing would be used as necessary to maintain habitat conditions at desirable levels to benefit species such as mule deer, sage grouse or black-tailed prairie dogs which have habitat needs of other than climax vegetation. Species such as sharp-tailed grouse would benefit from the general grazing pattern.

The graze-rest cycle would provide the optimal situation for shrub enhancement. This alternative, together with shrub plantings on 3000 acres and prescribed burning on 15,000 acres would help produce maximum shrub enhancement within a minimum period of time. It is estimated that 90 percent or better of the suitable sites would be in the desired condition within 50 years and 75 percent of suitable areas would be at or above desired levels for shrubs by the year 2000. Limited grazing and proposed shrub management practices would increase the habitat's ability to support an over-wintering population of from 6-15 deer $/ \mathrm{mi}^{2}$.

Buffalo would also be introduced at UL Bend in suitably fenced areas and replace cattle as a principal large grazer.

Range developments to be implemented include mechanical ripping of as much as 38,000 acres of dense clay and panspots range sites. This acreage is an estimate of those areas lying outside designated wilderness, which have potential for treatment because of salt content, low water infiltration rates and sparse vegetation. A two- to fivefold increase in vegetative biomass is possible by ripping on favorable sites (C. Clark personal communication). Wight et al. (1978) reported an increase in herbage production of 165 percent with 10 percent more plant-available soil water on panspots sites in southeast Montana following ripping of the soil surface. J. Rogers (personal communication) stated similar results are normally obtained through breaking the surface of panspots by ripping or furrowing. These improvements are expected to occur on the 38,000 acres proposed for ripping. The perched 
water table often present on these sites would be eliminated; water would be allowed to percolate through the soil profile and would help flush out accumulated salts; increased quantities of water would be available for plant uptake. Greater site productivity would occur as a result. Ripping this acreage would increase the carrying capacity of the refuge by a minimum of 3000 AUMs.

A boundary fence would be constructed around the entire refuge. This fence would limit livestock access onto the refuge and maintain desired levels of livestock to accomplish grazing objectives for habitat improvement. Construction of a boundary fence may impede some wildlife movement, but this would be partially compensated for by removal of numerous existing interior fences.

New recreation areas and related developments would be prohibited near sensitive wildlife habitat and incompatible activities would be curtailed during critical nesting and breeding seasons. Most recreational development would occur at areas already disturbed by facilities. Eliminating private cabins and establishing wildlife habitat on these areas would improve conditions for wildlife on the refuge.

\section{RECREATION AND CULTURAL RESOURCES}

Compared to the others, this alternative would contribute somewhat less than the Proposed Action and No Grazing alternatives toward meeting national and regional recreation requirements and needs identified in the Nationwide Outdoor Recreation Plan (Bureau of Outdoor Recreation 1973) and the Montana Statewide Outdoor Recreation Plan (Montana Department of Fish and Game 1978). It would still meet recreation objectives identified for CMR.

Increases in wildlife accompanying this action would provide some additional recreation opportunities in the form of viewing, photographing and hunting. The establishment of bison on the refuge would restore a sight familiar to the area in the $1800^{\prime} \mathrm{s}$ and provide the visitor with a living reminder of the animals that once flourished here. Introduction of peregrine falcons would necessitate restriction of human disturbance during the breeding season (Snow 1972).

Limited conflicts between recreation users and livestock would decline as livestock levels are reduced. Livestock damage to culturally or historically significant areas would decrease. There would be little interference between campers-hunters and livestock on some recreation areas. Because buffalo would be contained in fenced areas, there would be no conflicts with recreationists or cultural resources.

Ripping of dense clay and panspots range sites would have an adverse effect on visual resources for a minimum of 3-5 years. Prescribed burning would result in a lowering of visual quality for 1-5 years.

Visitors would be able to view buffalo and limited hunting opportunities would be possible as the population produced a harvestable surplus.

Due to increased use of refuge roads, there would be a corresponding increase in vehicular travel over roads leading into the refuge 
across adjoining BLM and private land. Proper planning in terms of a road system transportation plan would minimize potentially detrimental wildlife impacts. As a result, some additional use of BLM lands for recreation would occur. In addition private land owners would be expected to receive increased demand from recreationists seeking to travel through their land or hunt. Reductions in livestock grazing levels on the refuge would probably result in a less tolerant atiitude on the part of area ranchers toward any increased recreation use on adjacent private lands and a corresponding increase in closure of these lands to public use.

Moderate expansion of existing major recreation areas would create a minimum amount of disturbance to the landscape. Eliminating private cabin developments and restoring the land to wildlife habitat would reduce the number of people recreating on the refuge. The same would apply to high and low density recreation areas, which would involve less development than under the Proposed Action alternative.

Except for the degree of recreational development and use anticipated with this alternative, there would be about the same types of impacts as envisioned with the Proposed Action alternative. There would be some exceptions, however, since only nature trails and no backcountry trails would be established. Also, there would be less impact on cultural resources since damage by livestock would be reduced.

\section{SOCIOECONOMICS}

This alternative would decrease annual livestock AUMs by 37,285 between 1978-85 (Table 14). This reduction would have a direct negative economic impact of $\$ 254,000$, based on present value. However, between 1986-2000, direct positive economic effects of $\$ 30,744$ would be caused by an increase in annual AUMs from 22,823-26,833. Present value of this effect is $\$ 17,700$. Net present value of the total direct economic effects due to grazing changes is a negative $\$ 236,300$.

Indirect economic effects due to grazing would be a reduction in employment and income between 1978-85 of 47 man-years and $\$ 530,000$, respectively. Between 1986-2000, employment and income would increase by 5 man-years and $\$ 57,000$, respectively (Appendix 13).

Table 14 shows the annual visitation by category for the years 1985 and 2000. Existing condition figures (1978) are shown to facilitate comparison. Direct economic effects due to these annual increases in visitation would be $\$ 177,000$ between $1978-85$, and $\$ 182,500$ between 19862000. The present value of these direct economic effects is $\$ 994,600$.

Table 14 summarizes the noneconomic effects which would result from implementation of the Intensive Wildlife Management alternative. 
Table 14. Noneconomic effects, Intensive Wildlife Management alternative, Charles M. Russell National Wildlife Refuge, Montana.

\begin{tabular}{|c|c|c|c|}
\hline & \multirow{2}{*}{$\begin{array}{c}\text { Present } \\
\text { situation } \\
(1978)\end{array}$} & \multicolumn{2}{|c|}{$\begin{array}{c}\text { Intensive Wildlife } \\
\text { Management }\end{array}$} \\
\hline & & 1985 & 2000 \\
\hline \multicolumn{4}{|l|}{ Habitat quality1/ } \\
\hline Sharp-tailed grouse & 4.6 & 6.8 & 8.0 \\
\hline Mule deer & 5.6 & 7.3 & 8.0 \\
\hline Pronghorns & 5.2 & 6.6 & 7.1 \\
\hline White-tailed deer & 5.4 & 7.0 & 8.1 \\
\hline $\mathrm{E} 1 \mathrm{k}$ & 6.0 & 7.5 & 8.0 \\
\hline Waterfowl & 3.4 & 7.0 & 9.0 \\
\hline \multicolumn{4}{|l|}{ Development } \\
\hline Burn (acres) & 0 & 3800 & 15,000 \\
\hline Plant trees (acres) & 0 & 6250 & 25,000 \\
\hline Plant shrubs (acres) & 0 & 800 & 3000 \\
\hline Soil ripping (acres) & 0 & 0 & 38,000 \\
\hline Ponds (acres) & 0 & 225 & 900 \\
\hline \multicolumn{4}{|l|}{ Fences (miles) } \\
\hline Exclosure 21 & 0 & 13 & 52 \\
\hline Boundary (aprx.) & 50 & 50 & 450 \\
\hline Interior & Unknown & 0 & 0 \\
\hline \multicolumn{4}{|l|}{ Water projects (No.) } \\
\hline Ponds (aprx.) & 150 & 160 & 210 \\
\hline Troughs & 13 & 13 & 13 \\
\hline Springs & 0 & 0 & 0 \\
\hline \multicolumn{4}{|l|}{ Visitor days } \\
\hline FWS & 64,000 & 69,000 & 107,000 \\
\hline Other & 293,000 & 321,000 & 333,000 \\
\hline Total & 357,000 & 390,000 & 404,000 \\
\hline \multicolumn{4}{|l|}{ Forage (AUMs) } \\
\hline Wildlife & 50,000 & 87,500 & 107,000 \\
\hline Livestock (active) & $56,5243 /$ & 22,823 & 26,833 \\
\hline Total & 106,524 & 110,323 & 133,833 \\
\hline \multicolumn{4}{|l|}{ Range condition (\%) } \\
\hline Poor & 1 & 1 & 1 \\
\hline Fair & 7 & 7 & 4 \\
\hline Good & 74 & 67 & 15 \\
\hline Excellent & 18 & 25 & 80 \\
\hline
\end{tabular}

1/ $0-2.5=$ poor, $2 \cdot 6-5.0=$ fair, $5 \cdot 1-7.5=$ good and $7 \cdot 6-10.0=$ excellent.

2/ A precise estimate of acres enclosed/mile of fence is not provided due to presently undetermined topography and shape of exclosure. A general rule of thumb is 40 acres enclosed per mile of fence.

3/ These figures represent the active AUMs; 3584 AUMs are inactive totaling 60,108 AUMs. 


\section{ALTERNATIVE D}

(MULTIPLE USE)

\section{SOILS-WATERSHED}

Fire management practices would have the same consequences as the No Action alternative.

Temporary livestock reductions in several allotments plus soil ripping practices would provide moderate enhancement of soil productivity in treated areas. Areas not receiving these grazing or mechanical treatments could expect a slight improvement in conditions. Watershed quality enhancement would show similar trends.

An initial drop of about 4500 active livestock AUMs below present levels would occur in response to a need for enhancing present range conditions within several allotments. These decreases would occur primarily in the Big Dry Arm portion of the refuge where the most serious range condition problems are present. The effect of this temporary reduction would be to help eliminate an estimated 50 percent of the deteriorated range conditions on the refuge. Overland water runoff would be substantially lowered on these areas because of increased plant and litter cover, with soil erosion lowered as a result. Expected increases in litter and plant cover would be somewhere between present levels and those expected under the Proposed Action alternative. This in turn would place erosional rates for this alternative between the No Action and Proposed Action alternatives. Increased plant and litter cover would allow cycling of more minerals and nutrients through the soil.

The 38,000 acres proposed for ripping would have higher productivity, as previously discussed under other alternatives. Additional water developments, fencing and implementation of new grazing systems geared to specific allotment needs should serve to improve soils and watershed conditions primarily as a result of increased plant and litter cover which will reduce soil erosion and overland runoff. Although some proponents of rest-rotation grazing might point out that implementation of such systems refuge-wide would improve soils and watershed, an examination of available literature does not reveal a clear-cut distinction between this and other grazing systems. Gifford and Hawkins (1976) evaluated nine separate studies that reflected impacts of various grazing systems, including rest-rotation, on plant or litter cover. They concluded that published evidence failed to show that any one grazing system consistently or significantly increases plant and litter cover on watersheds. A more realistic situation would require evaluation of allotment deficiencies and implementation of grazing systems designed to overcome those specific deficiencies.

Soil resources would be more adversely impacted by this alternative than by the Proposed Action due to the significantly greater amount of visitation expected to occur. Increased vehicular traffic in the backcountry areas of the refuge could result in higher rates of erosion and rutting of access roads. 
Under this option, prairie dog control would have a short-term detrimental effect on the prairie dogs through direct reductions in populations. There would be indirect effects on various species dependent upon dog towns for portions of their life requirements; burrowing owls would have fewer home sites and raptors and terrestrial predators a smaller food base. Potential dens for black-footed ferrets would be eliminated.

Peregrine falcons would benefit as a result of slight increases in residual cover to increase suitable habitat for prey species.

There would be some competition between bighorn sheep and cattle. This would be especially detrimental if sheep were confined to a limited range also used by cattle, as in fall-winter use allotments where forage might be in short supply.

Lack of residual vegetation for cover and food is limiting to several species of wildlife. New grazing systems, seasons of use, temporary livestock reductions and habitat manipulation practices would provide a low to moderate amount of improvement in range and wildlife habitat quality across CMR. A smaller percentage of the refuge would remain in excellent condition as range improvement programs provide increased livestock access to formerly inaccessible areas. Areas of overuse would improve condition-wise as new improvements allow for better livestock distribution.

An estimated 50 percent of all potentially suitable sites on the refuge would have the desired 8-10 inches of residual cover by the year 2000 as a result of temporary reductions to enhance range condition and various treatments proposed under this action. This would provide suitable nesting sites for sharp-tailed grouse and provide spring breeding bird densities of approximately $10 \mathrm{birds} / \mathrm{mi}^{2}$ and benefit several other species as described under the Proposed Action alternative. It would help improve overall sharp-tailed grouse habitat from fair to good condition. Areas that would not have 8-10 inches of residual cover include those key livestock areas within one mile of water on level to moderate slopes that are used on an annual, seasonal basis during summer months. These areas would have fewer forbs and grasses.

Residual and emergent vegetation in and around ponds located on the refuge would continue to receive heavy use under livestock grazing during warm, dry weather. Pond development at UL Bend would cause some increase in waterfowl population levels.

Livestock grazing practices would be expected to result in maintenance or possibly a slight expansion of existing sage communities to benefit pronghorns and sage grouse, which, according to Wallstead (1971), Eng and Schladweiler (1972) and Bayless (1969), require areas of dense big sage (20-30 percent canopy coverage) for use throughout the year. An estimated 50 percent of the allotments having habitat shrub potential levels of good-excellent would reach these levels by the year 2000 .

Riparian areas grazed on an annual, seasonal or continuous basis would continue to receive heavy livestock use and only fenced areas would develop riparian communities of value to wildlife. Limited im- 
provements in shrub communities would be realized on allotments where rotation systems of grazing are implemented.

Key shrubs are lacking for use as food as well as cover and perches. Burning to enhance shrubs on 400 acres by 1985 and a total of 1500 acres by 2000 plus planting shrubs on 300 acres by 2000 would result in slight increases in shrubs. This would provide food and cover for mule deer but no significant changes in the habitat's ability to support an overwintering population of mule deer.

Overall habitat quality would increase 4-120 percent over the 20year period, depending upon species evaluated (Appendix 14).

Habitat quality and therefore capability to support wildlife would be increased only slightly over the present situation for most species. This situation, coupled with some increases in livestock grazing on the refuge, would mean little or no change in quality of habitat on adjacent lands.

The small improvement in riparian habitat would not significantly improve stream flows in continuous and intermittent streams or the fishery resource of the reservoir.

Rough terrain on the refuge limits effectiveness of fixed wing aircraft predator control. The use of helicopters would be more efficient but is also limited to some degree by topography. Aerial hunting combined with other types of control would reduce coyote populations on an annual basis but the effects would not be expected to permanently alter the coyote population. Impacts from prairie dog control would be the same as the No Action alternative. Coyote control for protection of other wildife would have no significant impacts on coyote populations. Other small mammal control would have the same impacts as the Intensive Wildlife Management alternative.

Forage allocations would provide enhancement of those allotments in deteriorated condition by substantial livestock reductions until improvements occur. Other allotments in good to excellent ecological condition would receive few, if any, reductions. Livestock AUMs would be increased as range conditions improve; initially approximately 50 percent of the AUMs in each allotment would be allocated to wildlife. Any increases in forage production resulting from improved range conditions would be allocated to resource values for which the greatest need exists (livestock, wildlife, watershed). Range objectives would not be achieved with this alternative as wildlife objectives would not be realized.

Approximately 18 allotments would receive increases in use. About 7000 AUMs of forage would be available for livestock and 4500 for wildlife on the UL Bend portion of the refuge that is presently ungrazed. Total federal livestock AUMs would be about 52,000 active by 1985 . Improved range conditions and range improvement programs would allow an increase in livestock use to a minimum of 61,260 active federal AUMs by the year 2000. This level would be increased as range conditions improve or where it is demonstrated that wildlife needs are being met. State and private land would be allowed additional AUMs, as conditions permit. It is felt that these areas are nearly stocked to capacity at present and any increases in AUMs would be small. 
Temporary reductions in livestock use in deteriorated areas would help shrub production and establishment. Under seasonal or continuous grazing, which would be retained for most allotments, no significant increases in shrub production would occur and trampling of shrubs would continue to be a problem.

Approximately 12 additional allotments under seasonal, continuous or year-long use would be put into a rotation (deferred or rest) system of grazing. Fencing and water developments would be constructed in these and other allotments as needed.

Many of the remaining allotments have size, topographic or other constraining factors which would preclude adoption of grazing systems which incorporate periods of rest. Under seasonal or continuous use, proposed stocking levels would continue to provide some limitation to shrub abundance and quality. However, better distribution of livestock through range improvement projects and increases in range condition would provide a gradual rate of enhancement because of improved forage conditions on so-called primary livestock range areas. Improved conditions on these areas could lower livestock use on more remote and rugged areas where competition with wildlife would be more likely.

Reservoir, spring and pipeline development would create about 90 new watering facilities on the refuge by 2000. This would provide improved livestock distribution and eliminate some deteriorated conditions on present concentration areas. However, all water facilities would still receive a disproportionate amount of use under seasonal grazing systems and would not achieve desired wildlife cover levels. Under a grazing system where rest intervals are provided, desired cover levels would probably be met at least during deferred or rest phases of the cycle. Some fencing of reservoirs would occur in pastures used on a seasonal basis to improve habitat conditions.

Other developments such as boundary fences would eliminate excessive numbers of livestock which tend to move onto the refuge during hot, dry weather. Interior fences would be constructed to implement new grazing systems to benefit range conditions, wildlife habitat and livestock management. No significant detrimental impacts to wildlife are expected to occur as a result of fence construction. Ripping of 38,000 acres would create a minimum 3000 AUMs of additional forage for wildlife and livestock. Additional forage, stocking within authorized levels and better water distribution would reduce grazing pressure on those areas which are presently substandard in terms of residual vegetation and achieve desired levels of 8-10 inches of cover on 50 percent of potentially suitable areas by the year 2000 .

The season of use for livestock would be provided to meet the individual operator's needs as much as possible, while considering growth needs of major forage plant species and critical wildlife values.

Effects of livestock grazing under various grazing systems have been observed to be both beneficial and detrimental to wildlife (Appendix 16). Stevens (1966) and Mackie (1970) found that elk in Montana prefer areas which have had little use by cattle and that their movements are influenced by presence of cattle. Skovlin et al. (1968) found that elk use in the Blue Mountains of Oregon was significantly less on 
range cohabited with cattle than in areas where cattle use was restricted. Rates of elk use decreased as cattle stocking increased but moderate cattle stocking inhibited elk as much as heavy cattle stocking. Skovlin and Harris (1970) found that elk preferred season-long cattle ranges to deferred rotation ranges when cattle stocking was light. However, elk preferred heavily stocked deferred rotation ranges to heavily stocked season-long ranges. Knowles (1975) found that elk tended to concentrate in areas not grazed by cattle on the Nichols Coulee allotment of CMR. Wittinger (1978) reported similar findings in the Salmon River drainage of Idaho. This distribution pattern suggests that land use competition occurs between elk and cattle. Knowles (1975) also suggested that limited mobility of mule deer made them vulnerable to any situation which resulted in intensive use of their home range by other ungulates. Intensive livestock grazing could therefore have detrimental impacts upon mule deer populations.

In looking at impacts of rest-rotation upon smaller forms of wildlife, Gjersing (1975) indicated that both breeding pairs of ducks and broods increased in response to periodic relief (rest-rotation) from grazing. This alternative would be expected to significantly affect wild ungulates by increasing opportunities for competition for forage. Social intolerance would be an important factor which would lower habitat quality for mule deer and elk. Sharp-tailed grouse would be adversely affected by lower residual cover levels in some areas. Some benefits to mule deer and sage grouse could be expected in terms of improved sagebrush communities for winter forage. Livestock feeding patterns would tend to maintain or expand existing communities. Prairie dogs and their associated species are expected to benefit from the Multiple Use alternative which would maintain heavy livestock use areas in a disturbed condition. The net effect is expected to be a slight improvement over existing conditions (Appendix 14) for most wildlife species but considerably below the potential that exists if other alternatives are implemented. This alternative would not accomplish the wildlife objectives for CMR.

With the following exceptions, there would be the same recreational impacts as envisioned with the Proposed Action alternative. Development of a major backcountry (nonmotorized) trail as well as establishment of primitive campsites and sport fishing access sites at various locations throughout the refuge would increase dispersed recreation use and result in some conflicts with wildlife due to the greater number of people using remote sections.

Construction of a perimeter shoreline scenic road in the vicinity of Fort Peck would destroy a significant area of prime elk habitat and would probably cause a reduction in the herd. There also would be occasional disturbance of sharp-tailed grouse in spring when they use dancing grounds. Proper planning and implementation of a refuge transportation plan would minimize detrimental impacts to wildlife.

\section{RECREATION AND CULTURAL RESOURCES}

of the five alternatives considered, this alternative would con- 
tribute the greatest amount toward meeting national and regional recreation requirements and needs identified in the Nationwide Outdoor Recreation Plan (Bureau of Outdoor Recreation 1973) and Montana Statewide Outdoor Recreation Plan (Montana Department of Fish and Game (1978). Recreation objectives approved for CMR would be satisfied.

Introduction of peregrine falcons would necessitate restriction of human disturbance during the breeding season (Snow 1972). Habitat improvements would be minor, therefore wildlife hunting and viewing opportunities would not change significantly.

Forage allocations under the Multiple Use alternative would provide an initial reduction in livestock AUMs to allow range recovery in several allotments. This would provide visual enhancement of these areas as perennial mid-grass species begin to replace perennial shortgrasses and annual forbs and grasses. Increases in livestock levels to 7000-7500 AUMs on UL Bend would lower pristine qualities of this portion of the refuge for some people where no livestock are presently grazed. Increased livestock use would increase opportunities for conflict between recreation and livestock grazing on high use recreation areas.

Ripping of dense clay and panspots range sites would cause a visual intrusion for a minimum of 3-5 years. Other range developments such as interior fencing and construction of new reservoirs could lower environmental quality of the refuge for those individuals desiring a natural setting. Prescribed burning would result in a lowering of visual quality for $1-5$ years.

In addition to those impacts discussed under the Proposed Action alternative, there would be increased use resulting from designation of a backcountry foot and horse trail running the length of the refuge and expansion of low density recreation areas. Expansion of interpretive facilities and attendant increases in wildlife-wildlands activities would present a more favorable image of the refuge to a greater number of people than with any of the other alternatives.

Due to the larger number of people who would recreate on the refuge under this alternative, there would be some conflicts between recreationists. Due to increased use of refuge roads, there would be a corresponding increase in vehicular travel over roads leading into the refuge, across adjoining BLM and private lands and some additional use of BLM lands for recreation. Some increased recreation use is expected off the refuge as a result of implementation of this alternative.

\section{SOCIOECONOMICS}

This alternative would reduce AUMs granted to refuge permittees from 60,108 in 1978 to 52,096 in 1985, a decrease of 8012. This decrease would represent a direct negative economic effect on permittees of $\$ 54,600$. From 1986-2000, AUMs would be increased from 52,096-61,260, an increase of 9164 AUMs representing a positive economic impact of $\$ 70,300$. The net present value of these direct economic effects from changes in grazing is a negative $\$ 14,100$. Expected impacts upon individual ranchers are shown in Appendix 10. Only two operators are 
expected to suffer high adverse consequences by the Multiple Use alternative to the extent that their business would be jeopardized.

Indirect economic effects of the Multiple Use alternative result from AUM reductions that would cause a decrease in income of $\$ 128,000$ over the 8-year period from 1978-85 and an increase of $\$ 131,000$ between 1986-2000. This compares to total income in the region from farm sources of $\$ 70,934,000$ in 1975 . The net difference in total income between 1978-2000 is insignificant compared to average annual range livestock related earnings of $\$ 50.8$ million for the period 1970-75. Total income from all sources was $\$ 166,922,000$ in 1975.

Increases in visitation due to this alternative would have direct economic effects of $\$ 161,000$ between $1978-85$ and $\$ 219,000$ between $1986-$ 2000. Present value of these annual increases is $\$ 1,047,000$.

Indirect economic effects between 1978-85 would be an increase in employment and income of 28 man-years and $\$ 197,500$, respectively. Between 1986-2000, indirect effects would be an increase of 24 man-years of employment and $\$ 204,500$ in income.

Table 15 summarizes the noneconomic effects which would result from implementation of the Multiple Use alternative. 
Table 15. Noneconomic effects, Multiple Use alternative, Charles M. Russel1 National Wildlife Refuge, Montana.

\begin{tabular}{|c|c|c|c|}
\hline & $\begin{array}{c}\text { Present } \\
\text { situation } \\
(1978)\end{array}$ & $\begin{array}{r}M_{1} \\
1985 \\
\end{array}$ & $\begin{array}{l}\text { e Use } \\
2000 \\
\end{array}$ \\
\hline \multicolumn{4}{|l|}{ Habitat quality $1 /$} \\
\hline Sharp-tailed grouse & 4.6 & 4.8 & 5.3 \\
\hline Mule deer & 5.6 & 5.9 & 6.5 \\
\hline Pronghorns & 5.2 & 6.0 & 6.6 \\
\hline White-tailed deer & 5.4 & 5.7 & 6.9 \\
\hline E1k & 6.0 & 6.1 & 6.4 \\
\hline Waterfowl & 3.4 & 4.5 & 7.5 \\
\hline \multicolumn{4}{|l|}{ Development } \\
\hline Burn (acres) & 0 & 400 & 1500 \\
\hline Plant trees (acres) & 0 & 0 & 0 \\
\hline Plant shrubs (acres) & 0 & 100 & 300 \\
\hline Soil ripping (acres) & 0 & 0 & 38,000 \\
\hline Ponds (acres) & 0 & 225 & 900 \\
\hline \multicolumn{4}{|l|}{ Fences (miles) } \\
\hline Exclosure 2 I & 0 & 2 & 10 \\
\hline Boundary (aprx.) & 50 & 60 & 72 \\
\hline Interior & Unknown & 32 & 40 \\
\hline \multicolumn{4}{|l|}{ Water projects (No.) } \\
\hline Ponds (aprx.) & 150 & 167 & 227 \\
\hline Troughs & 13 & 23 & 26 \\
\hline Springs & 0 & 2 & 2 \\
\hline \multicolumn{4}{|l|}{ Visitor days } \\
\hline FWS & 64,000 & 72,000 & 88,000 \\
\hline Other & 293,000 & 333,000 & 370,000 \\
\hline Total & 357,000 & 405,000 & 458,000 \\
\hline \multicolumn{4}{|l|}{ Forage (AUMs) } \\
\hline Wildlife & 50,000 & 58,000 & 60,000 \\
\hline Livestock (active) & $56,524 \underline{3} /$ & 52,096 & 61,260 \\
\hline Total & 106,524 & 110,096 & 121,260 \\
\hline \multicolumn{4}{|l|}{ Range condition (\%) } \\
\hline Poor & 1 & 1 & 1 \\
\hline Fair & 7 & 7 & 4 \\
\hline Good & 74 & 74 & 80 \\
\hline Excellent & 18 & 18 & 15 \\
\hline
\end{tabular}

1/ $0-2.5=$ poor, $2 \cdot 6-5.0=$ fair, $5 \cdot 1-7.5=\operatorname{good}$ and $7 \cdot 6-10.0=$ excellent.

2/ A precise estimate of acres enclosed/mile of fence is not provided due to presently undetermined topography and shape of exclosure. A general rule of thumb is 40 acres enclosed per mile of fence.

3/ This figure represents active AUMs; 3584 AUMs are inactive totaling 60,108 AUMs. 


\section{ALTERNATIVE E}

(NO GRAZING)

\section{SOILS-WATERSHED}

Proposed fire management practices would result in opening of coniferous forest areas with increased grass and forb levels to retard runoff and soil loss. Elimination of grazing and implementing treatments such as planting and construction of temporary exclosures would provide more residual cover and shrub communities which would also retard runoff and decrease erosion. There would be no forage allocated to livestock under this alternative.

Soil erosion rates from man-caused actions would be minimal by the year 2000, following removal of all livestock from the refuge. Geologic erosion on steep or fragile sites would continue but at decreased levels because of increased plant and litter cover. It is not known if the decreased rates of erosion on these fragile sites would constitute a significant difference from present rates.

Soil erosion from overland runoff and wind is expected to decrease because of increased plant or litter cover. Bare ground exposed on more favorable range sites such as clayey, sandy, silty or overflow, could be expected to average 15 percent or less by 1985 and 5 percent or less by 2000. These levels have been achieved on similar range sites presently excluded from livestock use, whereas estimates of samples of grazed range sites in 1978 indicated an average of from 20-42 percent bare ground on the respective range sites for all samples taken.

Soil erosion rates would be minimal as they relate to accelerated erosion. Soil ripping practices plus increased plant and litter cover levels following removal of all livestock from CMR would provide attainment of the highest potential soils and watershed conditions on a refuge-wide basis. However, increased litter cover would provide for greater risk of uncontrollable wildfire. Litter accumulation may provide the necessary fuel for burns which may be hot enough to kill perennial grass species. Uncontrolled wildfires could conceivably result in massive soil losses through erosion, especially if vegetation is killed.

About 10,000 acres of accessible dense clay and panspots range sites would be treated by the year 2000. Such treatment would provide greater water infiltration, less overland runoff, a significant increase (two- to fivefold) in vegetative production and improved soil properties. The increased vegetative cover, in addition to reducing erosion, would provide additional forage and security cover for wildlife.

Interior fences would be allowed to deteriorate or would be removed and reservoirs on marginal sites allowed to fill with silt. Gradual reduction in grazing through the year 2000 would provide an accelerated rate of return to natural conditions with man-caused erosion effectively eliminated by the year 2000. Geologic erosion would continue actively on the more fragile and susceptible sites such as breaks and shale areas. 
The refuge boundary fence would serve to prevent all livestock use on refuge lands and maintain soil and watershed quality. No significant detrimental. impacts to wildlife are expected to result from boundary fence construction. Impacts of recreation and cultural resources would be the same as for the Proposed Action alternative.

\section{WILDLIFE HABITAT-RANGE RESOURCES}

Lack of residual vegetation for cover and food is limiting to several species of wildlife. Complete lack of grazing would provide adequate amounts (8-10 inches) of residual vegetation on almost all suitable sites. This would mean adequate nesting and hiding cover for sharp-tailed grouse, other ground nesting birds and some small mammals and forage for elk, mule deer and pronghorns. However, species such as the prairie dog would show a decline from the No Grazing action.

Reintroduction of black-footed ferrets and peregrine falcons would add diversity to wildlife on the refuge and help in re-establishing these endangered species.

Elimination of grazing and associated disturbances would mean a reduction in the number and size of prairie dog towns. As a result it would reduce habitat for such unique species as burrowing owls and mountain plovers as well as the potential success of swift fox and blackfooted ferret reintroductions. It would provide more favorable conditions for bighorn sheep (Eichhorn and Watts 1976). There would be a maximum percentage of suitable sites for sharp-tailed grouse to nest and thus a probable increase in sharp-tailed grouse. Habitat to support white-tailed deer would be excellent. Waterfowl numbers would increase somewhat while habitat to support pronghorns would decrease. Small mammals and birds show varied results to different grazing levels or lack of grazing depending upon their respective habitat requirements. Ground squirrels are discouraged from using heavy stands of tall grasses (Smith 1940). Pocket gophers prefer deteriorated range because of greater numbers of tap-rooted and bulbous-rooted plants (Buechner 1942). Meadow mice favor climax or near climax conditions (Vories and Taylor 1940).

Smith (1940) found that nongame birds quickly disappeared from overgrazed lands in the mixed grass prairie. Weatherill and Keith (1969) found that moderate grazing may improve habitat for such species as mountain plovers and western meadowlarks. Owens and Myres (1973) found that disturbance of a fescue grassland by mowing or cattle grazing reduced or eliminated Bairds' sparrow and Sprague's pipit but did not affect savannah or clay-colored sparrows and western meadowlarks and permitted ingress of prairie horned larks and chestnut-collared longspurs.

Range deterioration may reduce populations of some native birds and allow an increase of insects that damage residual grass (Daubenmire and Daubenmire 1968). Page et al. (1978) found that Nevada and California habitats had significantly lower densities and numbers of species of nongame wildlife on ungrazed versus grazed areas.

Residual cover for sharp-tailed grouse nesting would eventually be 
at a level of 8-10 inches on 95-100 percent of all suitable sites by elimination of livestock grazing. Some areas would have 10-12 inches of residual cover. This would greatly accelerate overall habitat improvement from fair to excellent for this species.

Effective management of sagebrush flats would be limited with no livestock grazing. Removal of livestock would eliminate a key tool in manipulation of sagebrush communities because of livestock preference for grasses and forbs over browse. The shrub canopy in these stands would be expected to decrease with time to canopy cover ranges of 5-20 percent. Grass and forb enhancement would occur. Value as critical winter range could decline slightly as a result of reduction in sagebrush stands while increased forb and grass production would make these communities more valuable for some wildlife during remaining seasons.

This option would provide maximum benefit to wildlife species associated with climax conditions. Those species associated with seral stages would suffer from loss of habitat and populations would suffer moderate declines. However, wildlife objectives would be met.

Because livestock grazing would be eliminated on the refuge, adjacent landowners might stock their own lands above carrying capacity levels. This heavy stocking could cause the most severe degradation of wildlife habitat on adjacent lands for any of the five alternatives. Range objectives would not be met with this alternative.

No livestock grazing would provide optimal rates of return to climax conditions by the year 2000. Minor drainages that have the potential of supporting riparian communities would do so under this alternative. Construction of temporary fences to exclude wildlife until shrubs are re-established and planting of shrubs would improve riparian conditions on treated sites. The final result would be an increase in habitat condition from good to excellent on sites capable of supporting a riparian community. The same would apply to upland ponds as suitable waterfowl habitat.

Key shrubs are lacking for use as food as well as cover and perches. No livestock grazing, when combined with prescribed burning-browse reseeding (11,300 acres) and seedling planting (500 acres), would provide excellent opportunities to reach desired shrub community levels. Desired shrub levels would be met or exceeded on 60 percent of potentially suitable sites by 2000 and on all suitable areas in 40-50 years.

Prescribed burning would increase deciduous browse which is vital as a source of mule deer winter food. K. Hamlin (personal communication) indicated forbs are important to mule deer in all snow-free seasons. Eichhorn and Watts (1974) found that shrub and forb production on wildfire burns in the Missouri River breaks was substantially higher than on unburned control areas. Burning to increase shrubs and forbs would help increase ability of the habitat to support over-wintering populations of over $12 \mathrm{deer} / \mathrm{mi}^{2}$.

Effects of increased burning in nonsagebrush communities and reduced levels of sagebrush on sagebrush flats would be somewhat offsetting to mule deer habitat. Deer would tend to make higher use of deciduous shrubs enhanced by burning for winter forage to replace sage, which is presently heavily used in the winter. 
Tree planting would occur on 4700 acres with impacts similar to the Intensive Wildlife Management alternative. Overall habitat quality would increase 13-144 percent over the 20-year period, depending upon species evaluated (Appendix 14). The refuge contains only a portion of the biological unit for elk; therefore, the elk population would not increase significantly, as it would be controlled by off-refuge factors.

All riparian areas would improve to their maximum potential along intermittent and continuous streams and would improve the fishery resource more than any other alternative.

Impacts for all animal damage control would be the same as the No Action alternative.

Federal livestock AUMs would be reduced by about 10 percent/year until the total elimination of livestock occurred. All state and private AUMs would be eliminated by the year 2000. All forage would be available for wildlife to fulfill habitat needs for food and cover by the year 2000. Habitat quality resulting would be such that it could support a sharp-tailed grouse spring breeding bird density of 35-40 birds/mi ${ }^{2}$. In addition, grass and especially forb levels, would increase for use by pronghorns, sage grouse and mule deer.

Impacts to wildlife habitat of implementing this alternative would be somewhat similar to the Proposed Action alternative except that all AUMs would be provided to wildlife for food and cover. No prescription grazing by livestock would be allowed and this would limit the scope of habitat management treatments to benefit wildlife species associated with seral stages of vegetation. The scope of improvements proposed would be less than for Intensive Wildlife Management. There is less likelihood that all wildlife objectives would be met or exceeded with this alternative.

With no forage allocated to livestock, it is possible that overall site productivity and vigor would decline slightly on a refuge-wide basis, since litter accumulations would lower the rate of seedling establishment and stifle new shoot growth on mature plants. However, a study of livestock exclosures in the Nichols Coulee area of the refuge does not lend support to one theory (Cosby 1978) that nonuse results in range stagnation. Clipping studies of livestock exclosures on the refuge protected from livestock grazing for approximately 12 years reveal no such range stagnation from nonuse. These excluded areas instead have higher productivity than similar sites which are grazed by livestock under a rest-rotation grazing system (Oldemeyer et al. 1980).

Ripping as much as 10,000 acres of dense clay and panspots range sites would improve vegetative productivity and residual cover levels for wildlife.

Impacts of recreation on wildlife habitat-range resources would be the same as described under the Proposed Action.

Short and long term vegetative productivity would be optimized by implementation of this alternative. Overall wildlife habitat quality would be optimized for climax habitat conditions and lowered significantly in terms of habitat diversity. 
As with the Proposed Action, this alternative would contribute an intermediate amount toward meeting national and regional recreation requirements and needs identified in the Nationwide Outdoor Recreation Plan (Bureau of Outdoor Recreation 1973) and the Montana Statewide Outdoor Recreation Plan (Montana Department of Fish and Game 1978). Recreation objectives identified for CMR would be met.

Introduction of peregrine falcons would necessitate curtailment of human disturbance during the breeding season (Snow 1972) in three smal1 areas. However, these areas are in the backcountry and presently receive only limited public use. Habitat management would provide some increased viewing and hunting opportunities. Effects of forage allocations would be similar to those provided under the Intensive Wildlife Management alternative, except that complete removal of livestock would enhance aesthetic qualities of the refuge for some recreationists. The complete removal of livestock from refuge lands would cause adverse reaction from adjacent landowners; they would close more of their land to public use.

Removal or deterioration of all existing internal range improvements would improve visual quality for wildlife-wildlands recreation. Impacts from ripping would primarily be associated with furrowing on upper soil horizons. These effects would last a minimum of 3-5 years. Prescribed burning would result in a lowering of visual quality for 1-5 years.

Impacts of this alternative would be about the same as those discussed for the Proposed Action. However, the primary difference between the two alternatives would be a small improvement in the quality of the recreation experience under the No Grazing alternative due to a reduction in conflicts between livestock and humans where they exist. Also, cultural resources would be subject to less disturbance, resulting in greater protection of sites and structures.

\section{SOCIOECONOMICS}

Federal AUMs would decrease from 60,108 in 1978 to 30,000 in 1985; AUMs would be reduced to zero between 1985-2000 (Table 16). Direct effects due to these reductions would total $\$ 205,000$ in the 8 -year period 1978-85. This amount represents the present value (1978). Direct effects of reduction from 1985-2000 would be $\$ 250,000$ with a present value of $\$ 144,000$. Total present value of these effects is a negative $\$ 349,000$. This amount can be considered as a measure of the relative magnitude of direct economic effects on permittees on the refuge. Since there were 87 permittees in 1979, this figure represents an average of slightly less than $\$ 4000 /$ permittee, assuming reductions were spread evenly among permittees. This would not be the case, however, because permittees would be affected according to the number of federal AUMs they normally purchase. As discussed previously, 10 permittees have over 48 percent of the AUMs. These permittees would be affected more than other permittees. Appendix 10 summarizes the impacts 
Table 16. Noneconomic effects, No Grazing alternative, Charles M. Russell National Wildlife Refuge, Montana.

\begin{tabular}{|c|c|c|c|}
\hline & $\begin{array}{c}\text { Present } \\
\text { situation } \\
(1978)\end{array}$ & $1985^{\mathrm{No}}$ & $\begin{array}{r}\text { Grazing } \\
2000 \\
\end{array}$ \\
\hline \multicolumn{4}{|l|}{ Habitat qualityl/ } \\
\hline Sharp-tailed grouse & 4.6 & 6.8 & 8.6 \\
\hline Mule deer & 5.6 & 7.0 & 7.5 \\
\hline Pronghorns & 5.2 & 5.9 & 6.3 \\
\hline White-tailed deer & 5.4 & 6.8 & 7.9 \\
\hline E1k & 6.0 & 7.0 & 7.8 \\
\hline Waterfowl & 3.4 & 6.0 & 8.3 \\
\hline \multicolumn{4}{|l|}{ Development } \\
\hline Burn (acres) & 0 & 2800 & 11,300 \\
\hline Plant trees (acres) & 0 & 1175 & 4700 \\
\hline Plant shrubs (acres) & 0 & 125 & 500 \\
\hline Soil ripping (acres) & 0 & 0 & 10,000 \\
\hline Ponds (acres) & 0 & 0 & 0 \\
\hline \multicolumn{4}{|l|}{ Fences (miles) } \\
\hline Exclosure 2 I & 0 & 2 & 6 \\
\hline Boundary (aprx.) & 50 & 50 & 450 \\
\hline Interior & Unknown & 0 & 0 \\
\hline \multicolumn{4}{|l|}{ Water projects (No.) } \\
\hline Ponds (aprx.) & 150 & 150 & 150 \\
\hline Troughs & 13 & 13 & 13 \\
\hline Springs & 0 & 0 & 0 \\
\hline \multicolumn{4}{|l|}{ Visitor days } \\
\hline FWS & 64,000 & 71,000 & 74,000 \\
\hline Other & 293,000 & 327,000 & 361,000 \\
\hline Total & 357,000 & 398,000 & 435,000 \\
\hline \multicolumn{4}{|l|}{ Forage (AUMs) } \\
\hline Wildlife & 50,000 & 80,000 & 130,000 \\
\hline Livestock (active) & 56,5243 / & 30,000 & 0 \\
\hline Total & 106,524 & 110,000 & 130,000 \\
\hline \multicolumn{4}{|l|}{ Range condition (\%) } \\
\hline Poor & 1 & 1 & 1 \\
\hline Fair & 7 & 7 & 4 \\
\hline Good & 74 & 67 & 15 \\
\hline Excellent & 18 & 25 & 80 \\
\hline
\end{tabular}

1/ $0-2.5=$ poor, $2.6-5.0=$ fair, $5.1-7.5=\operatorname{good}$ and $7.6-10.0=$ excellent.

2/ A precise estimate of acres enclosed/mile of fence is not provided due to presently undetermined topography and shape of exclosure. A general rule of thumb is 40 acres enclosed per mile of fence.

3/ This figure represents active AUMs; 3584 AUMs are inactive totaling 60,108 AUMs. 
for each permittee from implementing this alternative.

Reductions in grazing AUMs would reduce employment during 1978-85 by 38 man-years. Employment would be reduced by the same amount from 1986-2000. Total income in the region would be reduced by $\$ 426,000$ during both periods. Income losses can be compared to average yearly income from livestock sources of $\$ 50.8$ million. Income loss would represent only 0.8 percent of the average yearly income from livestock for the region.

Elimination of livestock grazing from the refuge could financially ruin many small, family-owned ranching operations which depend primarily upon refuge lands. Impacts would be moderate to high for most livestock operators, except those having only 40-50 AUMs presently licensed on the refuge. Those livestock operators suffering high negative impacts in Appendix 10 rould probably be forced out of business. A total of 15 operators are expected to suffer high adverse impacts from implementation of the No Grazing alternative to the extent that they would be forced out of business.

Unavoidable impacts associated with no livestock grazing include elimination of all domestic livestock from the refuge and varying degrees of adverse economic effects upon the livestock operators who presently graze livestock on the range.

Direct economic effects of changes in annual visitation are estimated at $\$ 170,500$ for $1978-85$ and $\$ 222,700$ for 1986-2000. Present value of these direct effects is $\$ 1,084,000$. Increases in visitation would also increase employment in the region by 22.5 man-years in 197885. From 1986-2000, 16 man-years would be added to employment. Income would increase by $\$ 168,800$ in $1978-85$ and by an additional $\$ 132,500$ from 1986-2000; these figures are undiscounted.

Table 16 summarizes the noneconomic effects which would result from implementation of the No Grazing alternative. 


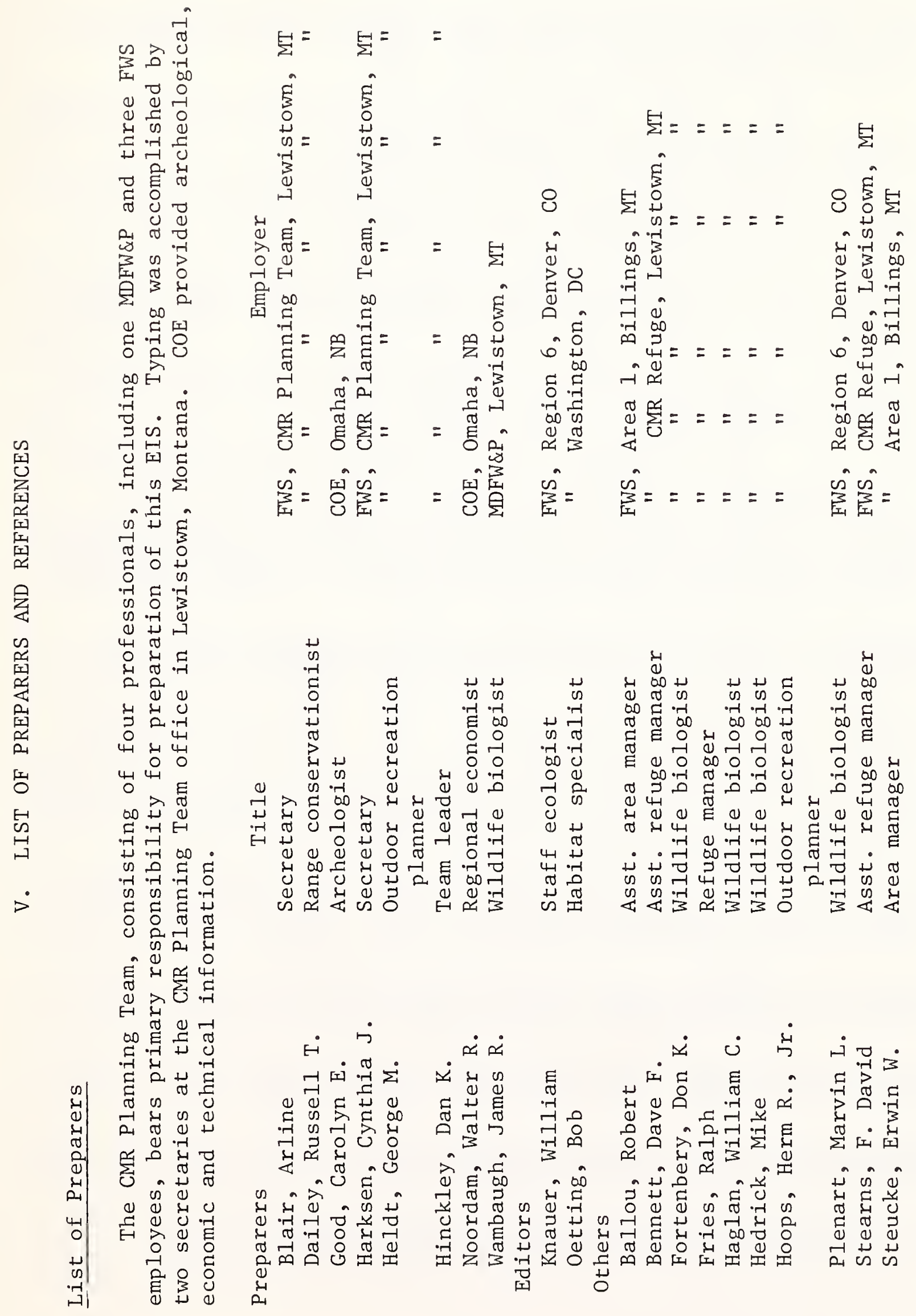




\section{References}

Alberta Recreation, Parks and Wildlife. Undated. Master planning study, Cypress Hills Provincial Park, summary of user study. Provincial Parks Division, Edmonton. 10pp.

- 1976. Master planning study, Cypress Hills Provincial Park, Briefs of public hearings. Edmonton. 207pp.

- 1977a. Master planning study, Cypress Hills Provincial Park, policy recommendations report. Edmonton. 17pp.

- 1977b. Master planning study, Cypress Hills Provincial Park, report on public meetings, October-December 1976. Edmonton. $9 \mathrm{pp}$.

Aldous, S. E. 1952. Deer browse clipping study in the lake states region. J. Wild1. Mgmt. 16(4):401-409.

Allen, O. E. 1968. Range use, foods, condition and productivity of white-tailed deer in Montana. J. Wild1. Mgmt. 32(1):130-141.

Alvord, W. 1979. A fishery review and management recommendation for waters of Charles M. Russell National Wildlife Refuge. Mont. Dept. of Fish, Wild1. and Parks, Helena. 42pp.

Ammann, C. A. 1957. The Prairie Grouse of Michigan. Mich. Dept. of Conservation Tech. Bull. East Lansing. 200pp.

Andersen, E. W. and R. J. Scherzinger. 1975. Improving quality of winter forage for elk by cattle grazing. J. Range Mgmt. 28:120-125.

Anderson, R. 1973. Water and eastern Montana coal development. Mont. Environmental Quality Council, Helena. 29pp.

Balda, R. P. 1975. The relationships of secondary cavity nesters to snag densities in western coniferous forest. Wildl. Habitat Tech. Bul1. No. 1, U.S. Forest Serv., Wash., D.C. $37 \mathrm{pp}$.

Baldwin, F. Undated. The off-road vehicle and environmental quality . The Conservation Foundation, Wash., D.C. 11pp.

Bayless, S. R. 1969. Winter food habits, range use, and home range of antelope in Montana. J. Wildl. Mgmt. 33(3):538-551.

Bennett, L. J. 1938. The Blue-winged Teal, Its Ecology and Management. Collegiate Press, Ames, IA. 144pp.

Bent, A. C. 1923. Life Histories of North American Wild Fow1. Part 1, U.S. Nat1. Mus. Bull. No. 126, Wash., D.C. 250pp. 
- 1937. Western red-tail. Pages 167-173 in Histories of North American Birds of Prey. Nat1. Mus. Bul1. No. 167. Wash., D.C.

Billings, M. G. 1977. Montana futures: a survey of citizen choices. Mont. Program Planning Stat. Center, Helena. 65pp.

Black, H. L. 1968. Populations of small rodents in relation to grazing by cattle on foothill ranges. M.S. Thesis, Univ. Utah, Salt Lake City. $56 \mathrm{pp}$.

Boecker, E. L. and F. D. Ray. 1971. Golden eagle population studies in the southwest. Condor 73(4):462-567.

Brandenberg, G. 1979. Personal communication. Range conservationist, Mont. Dept. of State Lands, Helena.

Brown, R. C. 1977. Personal communication. Wildlife biologist, Fish and Wild1. Serv., National Bison Range, Moiese, MT.

Brown, R. L. 1966. Response of sharp-tail breeding populations to annual changes in residual grassland cover. Forty-sixth annual conf. of Western Assoc. of State Game and Fish Commissioners, Butte, MT., Ju1y 12-14, 1966.

Bue, I. G., L. Blankenship and W. H. Marsha11. 1952. The relationship of grazing practices to waterfowl breeding populations and production on stock ponds in western South Dakota. Trans. N. Amer. Wildl. Conf. $17: 396-414$.

Buechner, H. K. 1942. Interrelationships between the pocket gopher and land use. J. Mamma1. 23(3):346-348.

1950. Life history, ecology and range use of the pronghorn antelope in Trans-Pecos, Texas. Amer. Mid1. Nat. 43(2):257-354.

Bureau of Land Management. 1976. Allotment management plan economic analysis. Inst. memo. No. 76-455, Wash., D.C. (unpaged).

1978a. Draft west-central North Dakota regional environmental impact study on energy development. Billings, MT. 242pp.

- 1978b. Upper Missouri wild and scenic river management plan.

Lewistown, MT. $76 \mathrm{pp}$.

- 1979a. Habitat management plan prairie dog ecosystems (draft). Montana State Office, Billings. 59pp.

- 1979b. Missouri Breaks grazing environmental statement.

Montana State Office, Billings. (unpaged). 
1979c. Wilderness inventory situation evaluations, Montana (Fergus, Garfield, McCone, Petroleum, Phillips and Valley counties). Lewistown. (unpaged).

Bureau of Outdoor Recreation. 1968. The middle Missouri, a rediscovery: a study of the outdoor recreation potential. Wash., D.C. 103pp.

- 1972a. Information brochure national wild and scenic river study, Missouri River from Fort Benton to Ryan Island in Montana. Denver, CO. $14 \mathrm{pp}$.

- 1972b. The 1970 survey of outdoor recreation activities, preliminary report. Wash., D.C. 105pp.

- 1972c. Western U.S. water plan outdoor recreation needs, working document. Wash., D.C. (unpaged).

D.C. $89 \mathrm{pp}$.

1973. Outdoor Recreation, a legacy for America. Wash.,

- 1976. The Lewis and Clark trail, a potential addition to the national trails system, final environmental statement. Wash, D.C. 300pp.

- 1977a. Missouri River, a wild and scenic river study. Wash., D.C. 105pp.

- 1977b. The Lewis and Clark trail, a proposed national

historic trail. Wash., D.C. 72pp.

Bureau of Reclamation. 1977. Report on the western energy expansion study. Wash., D.C. 66pp.

Bureau of Sports Fisheries and Wildlife. 1974. Proposed UL Bend Wilderness area, Montana, draft environmental statement, No. 74-52, Wash., D.C. 68pp.

Bureau of Sport Fisheries and Wildlife and Bureau of Land Management. 1975. Proposed Charles M. Russell National Wildlife Range wilderness area, draft environmental statement, No. 74-54. Wash., D.C. 136pp.

Bureau of The Census. 1977. County and City Data Book. Wash., D.C. $56 \mathrm{pp}$.

Burgess, H. H., H. H. Prince and D. L. Trauger. 1965. Blue-winged teal nesting success as related to land use. J. Wildl. Mgmt. 29(1):8995.

Call, M. 1978. Nesting habitats and surveying techniques for common western raptors. Bureau of Land Management Tech. Note TN-316. Denver, CO. 115pp. 
Campbel1, R. B. 1978. Personal communication. Wildlife biologist, Mont. Dept. of Fish, Wildl. and Parks, Glasgow.

- 1979. Personal communication. Wildlife biologist, Mont. Dept. of Fish, Wild1. and Parks, Glasgow.

Caras, R. A. 1967. The masked bandit: the raccoon. Pages 140-146 in North American Mammals, (ed.) R. A. Caras. Meredith Press, NY.

Christenson, C. D. 1971. Habitat preferences of the sharp-tailed grouse. M.S. Thesis, Univ. North Dakota, Grand Forks. 53pp.

Clark, C. 1978. Personal communication. Soil scientist, Soil Conservation Serv., Lewistown, MT.

Cole, G. F. 1956. The pronghorn antelope: its range use and food habits in central Montana with special reference to alfalfa. Mont. State Coll. Exp. Stn. Bul1. 516, Bozeman. 63pp.

and B. T. Wilkins. 1958. The pronghorn antelope: its range use and food habits in Central Montana with special reference to wheat. Mont. Dept. of Fish and Game Tech. Bull. No. 2. Helena. $39 \mathrm{pp}$.

Constan, K. 1978. Middle Missouri River Project. Job Proj. Rept. No. FW-3-R, -5, and 6. Mont. Dept. of Fish, Wildl. and Parks, Helena.

Corps of Engineers. 1975. Boating and recreation, Fort Peck Lake.

Fort Peck, MT. 22pp.

- 1976. The Missouri River main stem system, operation and maintenance, draft environmental statement. Omaha, NE. 192pp.

- 1977a. Brochure, Fort Peck Dam and Lake, Montana. Omaha, NE. (unpaged).

- 1977b. Lakeshore management plan. Design Memorandum No. MFP-105C, Appendix F to the Master Plan. Omaha, NE. (unpaged).

- 1977-78. Reservoir project monthly visitation data.

Ornaha, NE. (unpaged).

Cosby, H. 1978. Range management benefits wildlife. Rangeman's Journal. 5 (5) : 158-161.

Costello, D. F. 1966. The World of the Porcupine. J. B. Lippincott Co., Philadelphia and New York. 157pp.

Couey, F. M. 1946. Antelope foods in southeastern Montana. J. Wild1. Mgmt. $10(4): 367$. 
Council on Environmental Quality. 1979. Regulations for implementing the procedural provisions of the National Environmental Policy Act. Wash., D.C. 44pp.

Creston Valley Wildlife Management Authority. 1974. Literature Review, habitat requirements for ground-nesting waterfowl and effect of grazing and other cover removal activities on nesting. $36 \mathrm{pp}$.

Crissey, W. F. 1968. Informational needs for Canada goose management programs, pages 141-147 in R. L. Hine and C. Schoenfield (eds.) Canada Goose Management. Dembar Educ. Res. Serv., Madison, WI.

Cutler, W. 1978. Personal communication. Area Manager, Bureau of Land Management, Lewistown, MT.

Dalke, P. D., D. B. Pyrah, D. C. Stanton, J. E. Crawford and E. F. Schlatter. 1963. Ecology, productivity, and management of the sage grouse in Idaho. J. Wildl. Mgmt. $27(4): 811-841$. , R. D. Beeman, F. J. Kindel, R.S. Robel and T. R. Williams. 1965. Use of salt by elk in Idaho. J. Wild1. Mgmt. 29(2):319-322.

Daubenmire, R. F. and J. B. Daubenmire. 1968. Forest vegetation of eastern Washington and northern Idaho. Wash. Agric. Exp. Stn. Tech. Bu11. 61. Pullman. 104pp.

Davis, D. E. 1955. Observations on the breeding biology of kingbirds. Condor 57:208-212.

Department of the Interior. 1974. Westwide study report on the critical water problems facing the eleven western states, preliminary review draft. Wash., D.C. (unpaged).

Dood, A. R. 1978. Summer movements, habitat use and mortality of mule deer fawns in the Missouri River Breaks, Montana. Job Final Rept., Proj. W-126-R-8, 9. Helena. 55pp.

Drewien, R. C. and P. F. Springer. 1969. Ecological relationships of breeding blue-winged teal to prairie potholes. Pages 102-105 in Saskatchewan Wetlands Seminar, Can. Wild1. Serv. Rept. Ser. No. 6.

Dusek, G. L. 1971. Range relationships of mule deer in the prairie habitat, north-central Montana. M.S. Thesis, Mont. State Univ., Bozeman. 63pp.

Eckert, R. E., Jr., M. K. Wood, W. H. Blackburn and F. F. Peterson. 1979. Impacts of off-road vehicles on infiltration and sediment production of two desert soils. J. Range Mgmt. 32(5):394-397.

Economics Statistics and Cooperative Service. 1979. Farm real estate market developments. U.S. Dept. Agriculture, Wash., D.C. 70pp. 
Edminister, F. C. 1954. American Game Birds of Field and Forest. Charles Scribner's Sons, NY. 490pp.

Eichhorn, L. C. and C. R. Watts. 1974a. Bighorn sheep in the Missouri River Breaks of Montana. Presented at the Northern Wild Sheep Council Meeting in Great Falls, MT.

- 1974b. Vegetation responses following fires in the Missouri River Breaks in Montna. Bureau of Land Management Watershed and Wildlife Workshop, Billings. 16pp.

- 1976. Two Calf bighorn sheep progress report. Bureau of Land Management, Lewistown, MT. $18 \mathrm{pp}$.

Einarsen, A. S. 1948. The Pronghorn Antelope and Its Management. Wild1. Mgmt. Inst., Wash., D.C. 235pp.

Eillisor, J. E. 1969. Mobility of white-tailed deer in South Texas. J. Wild1. Mgmt. 3(1):221-222.

Eng, R. L. 1948. Environmental control for increasing muskrat pro duction. Trans. N. Amer. Wildl. Conf. 13:596-605.

Errington, P. L. 1963. Muskrat Populations. Iowa State Univ. Press, Ames. 665p .

Eyre, L. and D. Paul. 1973. Raptors of Utah. Utah Res. Pub. No. 737. Salt Lake City.

Firebaugh, J. E. 1969. Relationships of mule deer to livestock on summer range in the Pryor Mountains, Montana. M.S. Thesis, Mont. State Univ., Bozeman. 55pp.

Fish and Wildlife Service. 1976a. Operation of the National Wildlife Refuge System, final environmental statement. Wash., D.C. (unpaged).

- 1976b. Wildlife output criteria. Unpubl. rept. Malheur National Wildl. Refuge, OR. $46 \mathrm{pp}$.

- 1978. Preliminary survey of visitor use and preferences. Unpubl. rept. Lewistown, MT. (unpaged).

- 1979a. Final recommendations on the management of the

National Wildlife Refuge System. Wash., D.C. 39pp.

- 1979b. Migratory bird program management document, draft. Wash., D.C. 42pp.

- 1979c. PPBE Hunt Report. Lewistown, MT. 15pp. 
- 1979d. Range survey, Charles M. Russell National Wildlife Refuge, Montana. Unpubl. rept. Lewistown, MT. (unpaged).

- 1979e. Wildlife survey, Charles M. Russell National Wildlife Refuge, Montana. Unpubl. rept. Lewistown, MT. (unpaged).

Flath, D. L. 1978. Nongame species of special interest and concern. Mont. Dept. of Fish, Wildl. and Parks, Helena. 7lpp.

Flinders, J. and R. M. Hansen. 1975. Spring population responses of cottontails and jack rabbits to cattle grazing short grass prairie. J. Range Mgmt. 28(4):29-293.

Forest Service. 1977a. A directory of research natural areas on federal lands of the United States of America. Federal Committee on Ecological Reserves, Wash., D.C. 280pp.

- J.W. Thomas (ed.). 1977b. Forest-Wildlife relationships in the Blue Mountains of Washington and Oregon. Pac. N.W. Forest and Range Exp. Stn., Portland, OR. (unpaged).

- 1964. Range Analysis Handbook. (unpaged).

Fort Peck Forward Committee. 1977. Recommendations and priorities for initial recreational development projects at Fort Peck Lake. Glasgow, MT. $45 \mathrm{pp}$.

Fortenbery, D. 1967. Black-footed ferret survey on the Charles M. Russell National Wildlife Range. Unpubl. rept., Lewistown, MT. (unpaged).

Fowler, R. 1978. Swift Fox Investigation and Restoration. Compiled from reference material written by J. Sharp and C. Hillman. Presentation made to joint meeting of the Society for Range Management and Soil Conservation Society of America.

Frickle, R. 1975. Socioeconomic profile, South Central Montana region. Bureau of Land Management, Billings. (unpaged).

Gallizioli, S. 1977. Statement, pages 90-96, in Improving fish and wildlife benefits in range management. Proc. of a seminar. Fish and Wild1. Serv., Wash., D.C. 118pp.

Geis, M. B. 1956. Productivity of Canada geese in the Flathead Valley, Montana. J. Wildl. Mgmt. 20(4):40-419.

Geist, V. 1971. Mountain Sheep, a Study in Behavior and Evolution. The Univ. of Chicago Press, Chicago, IL. 383pp. 
Geological Survey. 1979. Mineral resources of the Charles M. Russell Wildlife Refuge, Fergus, Garfield, McCone, Petroleum, Phillips and Valley Counties, Montana. Denver, CO. 178pp.

Gifford, G. and R. Hawkins. 1976. Grazing systems and watershed management: a look at the record. J. Soil and Water Conser. 33(6):281283.

Giles, L. W. 1942. Utilization of rock exposures for den and escape cover by raccoons. Am. Mid1. Nat. 27:171-176.

Gjersing, F. 1975. Waterfow1 production in relation to rest-rotation grazing. J. Range Mgmt. 28(1):37-42.

Grange, W. W. 1948. Wisconsin grouse problems. Wisc. Conser. Dept. Pub. No. 338.

Grasslands Hearings Board. 1976. Report of the public hearings board on the proposed Grasslands National Park. Regina, Saskatchewan. $116 \mathrm{pp}$.

Gray, G. M. 1967. An ecological study of sage grouse broods with reference to nesting, movements, food habits and sagebrush stripspraying in the Medicine Lodge Drainage, Clark County, Idaho. M.S . Thesis, Univ. of Idaho, Moscow. 200pp.

Grinne11, J. and A. H. Miller. 1944. The distribution of birds of California. Cooper Ornithological Club, Berkeley.

Hamlin, K. 1979. Personal communication. Wildlife biologist, Mont. Dept. of Fish, Wildl, and Parks, Lewistown, MT.

Hood, R. E. and J. M. Inglis. 1974. Behavioral responses of whitetailed deer to intensive ranching operations. J. Wildl. Mgmt. 38(3): 488-498.

Hoover, R. L., C. E. Till and S. Ogilvie. 1959. The antelope of Colorado. Tech. Bul1. No. 4. Colo. Dept. of Fish and Game, Denver. 110pp.

Hormay, A. 1970. Principles of rest-rotation grazing and multiple use management. Bureau of Land Management and Forest Serv., Wash., D.C. $26 \mathrm{pp}$.

- 1976. Personal correspondence. Grazing consultant, selfemployed. Memorandum to Rock Springs District Manager, dated September 1, 1976, subject: telephone conversation with Bruce Smith on rest-rotation grazing management.

(unpaged).

1980. Rest-rotation report. Unpubl. rept. Lewistown, MT . 
Jackman, S. M. and J. M. Scott. 1975a. Golden eagle (Aquila chrysactos). Pages 85-105 in Forest Serv. Region 6 literature review of twentythree selected forest birds of the Pacific Northwest. Portland, OR.

- 1975b. Mountain bluebird. Pages 374-382 in Forest Serv. Region 6 literature review of twenty-three selected forest birds of the Pacific Northwest. Portland, OR.

- 1975c. Red-tailed hawk (Buteo jamaicensis). Pages 68-84 in Forest Serv. literature review of twenty-three selected forest birds of the Pacific Northwest. Portland, OR.

Jeffrey, D. E. 1963. Factors influencing elk distribution on Willow Creek summer range. Unpubl. M.S. Thesis, Utah State Univ., Logan. 46pp.

Johnson, R. 1980. Personal communication. Regional Supervisor, Mont. Dept. Fish, Wild1. and Parks, Glasgow, MT.

Joint Federal-Provincial Committee on the Proposed Grasslands National Park. 1975. A proposed Grasslands National Park: what would it mean? Regina, Saskatchewan. 21pp.

Jones, C. 1978. Personal communication. Maintenance man, Fish and Wildl. Serv., Slippery Ann Wildl. Stn., Roy, MT.

Julander, 0. 1937. Utilization of browse by wildlife. Trans. N. Amer. Wildl. Conf. 2:226-287.

, and D. F. Jeffrey. 1964. Deer, elk, and cattle range relations on summer range in Utah. Trans. N. Amer. Wildl. Conf. $29: 404-414$.

Karuziak, D., H. Vriend, J. G. Stelfox and J. R. McGillis. 1977. Effects of livestock grazing on mixed prairie range and wildlife within PFRA, Suffield Military Reserve: Can. Wildl. Serv., Edmonton, Alberta. (unpaged).

Keith, L. B. 1961. A study of waterfowl ecology on small impoundments in Southeastern Alberta. Wildl. Monogr. No. 6. 88pp.

Kindschy, R. R. 1977. Rangeland management practices and bird habitat values. Workshop on nongame bird habitat management in coniferous forests of the Western United States.

King, R. 1980. Personal communication. Park technician, Corps of Engineers, Fort Peck, MT.

Kirsch, L. M. 1969. Waterfowl production in relation to grazing. J. Wild1. Mgmt. 33(4):821-828. 
and K. F. Higgins. 1976. Upland sandpiper nesting and management in North Dakota. Wild1. Soc. Bul1. 4(1):16-20.

Klebenow, D. A. 1969. Sage grouse nesting and brood habitat in Idaho. J. Wild1. Mgmt. 3(3):313-320.

Klipple, G. and D. Costello. 1960. Vegetation and cattle responses to different intensities of grazing on short-grass ranges on the central Great Plains. U.S. Dept. of Agriculture Tech. Bull. 1216. Wash., D.C. $82 \mathrm{pp}$.

Knowles, C. J. 1975. Range relationships of mule deer, elk and cattle in a rest-rotation grazing system during summer and fall. M.S. Thesis, Mont. State Univ., Bozeman. 111pp.

- 1976. Pages 95-106 in Mule deer population ecology, habitat relationships and relations to livestock grazing management in the Missouri River Breaks, Montana. Unpubl. Job. Prog. Rept., Federal Aid. Mont. Dept. Fish and Game, Helena.

- 1979. Personal communication. Wildlife biologist, Mont. Dept. of Fish, Wild1. and Parks Lewistown.

Komberec, T. J. 1976. Range relationships of mule deer, elk and cattle in a rest-rotation grazing system during winter and spring. M.S. Thesis, Mont. State Univ., Bozeman. 79pp.

Krefting, L. W., M. H. Stenlund and R. K. Seeme1. 1966. Effect of simulated and natural deer browsing on mountain maple. J. Wild1. Mgmt. $30(3): 481-488$.

Kufeld, R. C., O. C. Wallmo and C. Feddema. 1973. Foods of the Rocky Mountain mule deer. Res. Paper RM 111. Rocky Mt. Forest and Range Exp. Stn., Fort Collins, CO. 31pp.

Kuntz, Gail. 1979. Montana energy almanac, 1978. Mont. Dept. Natural Resources and Conser., Helena. 145pp.

Lackschewitz, K. 1979. Personal communication. Curator, Univ. Mont. Herbarium, Missoula.

Larsen, W. 1979. Personal communication. Soil scientist, Miles City, MT.

Longhurst, W. H., E. O. Garton, H. F. Heady and G. E. Connolly. 1976. The California deer decline and possibilities for restoration: pages 74-103 in Cal-Neva Wild1. Trans. 1976.

, H. K. Oh, M. B. Jones and R. E. Kapner. 1968. A basis for the palatability of deer forage plants. Trans. N. Amer. Wildl. Nat. Res. Conf. 33:181-192. 
Lonner, T. N. 1975. Long Tom Creek Study, pages 60-72 in Montana Cooperative Elk-logging study. Unpubl. Job Prog. Rept., Cooperative Aid Proj. W-120-R. Mont. Dept. of Fish and Game, Helena. 146pp.

Lusby, G. S. 1970. Hydrologic and biotic effects of grazing versus nongrazing near Grand Junction, Colorado. J. Range Mgmt. 23(4): 256-260.

Mackie, R. J. 1970. Range ecology and relations of mule deer, elk and cattle in the Missouri River Breaks. Wild1. Monogr. No. 20. 79pp.

- 1976a. Interspecific competition between mule deer, other game animals and livestock. Pages 49-54 in Mule deer decline in the West: a symposium. Utah State Univ., Coll. of Nat. Res. Agric. Exp. Stn., Logan.

- 1976b. Pages 67-94 in Montana Deer Studies: Mule deer population ecology, habitat relationships and relations to livestock grazing management and $e l k$ in the Missouri River Breaks, Montana. Job. Comp. Rept., W-120-R-7. Helena .

- 1978. Impacts of grazing on wild ungulates. Presented at N. Amer. Wildl, and Nat. Res. Conf., Phoenix, AZ. 32pp.

MacMillan, J. A. Undated. Analysis of socioeconomic impacts of the proposed Grasslands National Park. Report prepared for the Joint Federal-Provincial Committee on the Proposed Grasslands-National Park. Dept. of Agric. Economics, Univ. of Manitoba, Winnipeg.

Manolis, T. 1973. The eastern kingbird in California. Western Birds. $4(2): 33-44$.

Marshal1, W. H., G. W. Gullion and R. G. Schwab. 1962. Early summer activities of porcupines as determined by radio positioning techniques. J. Wild1. Mgmt. 26(1):75-79.

Martin, N. S. 1970. Sagebrush control related to habitat and sage grouse occurrence. J. Wild1. Mgmt. 34(2):313-320.

Maser, C. (ed.) 1974. The sage vole, Lagurus curtatus in the Crooked River National Grassland, Jefferson County, Oregon. A contribution to its life history and ecology. Saugertierkudliche Mitteilungen. $3: 193-222$.

Mayr, E. 1963. Animal Species and Evolution. Harvard Univ. Press, Cambridge, MA. 797pp.

McCaffery, K. R. and W. A. Creed. 1969. Significance of forest openings to deer in northern Wisconsin. Wisc. Dept. Natural Resources Tech. Bull. No. 44. Madison. 104pp. 
McClure, H. E. 1943. Ecology and management of the mourning dove, Zenaidura macroura (linn.) in Case County, Iowa. Res. Bull. No. 310. Agric. Exp. Stn., Iowa State College, Ames.

McEneaney, T. D. and J. L. Jensen. 1974. Status of the black-tailed prairie dog on the Charles M. Russell National Wildlife Range. Fish and Wildl. Serv., Lewistown, MT. 70pp.

McGahan, J. 1968. Ecology of the golden eagle. Auk 84(1):1-12.

McMahan, C. A. 1964. Comparative food habitat of deer and three classes of livestock. J. Wild1. Mgmt. 28(4):798-808.

Michigan State University and Bureau of Outdoor Recreation. 1971. Proceedings of the 1971 snowmobile and off the road vehicle research symposium. Tech. Rept. No.8, East Lansing, MI. 196pp.

Miller, W. 1970. Factors influencing the status of the eastern and mountain bluebirds in southwestern Manitoba. Blue Jay 28:38-46.

Missouri Basin Inter-Agency Committee. 1971. The Missouri River Basin comprehensive framework study, Vol. 1. Wash., D.C. 274pp.

Montana Department of Community Affairs. 1977. County Profiles (Fergus, Garfield, McCone, Petroleum, Phillips, Valley Counties). Helena, MT. 40pp each.

- 1978. County Profiles (Fergus, Garfield, McCone, Petroleum, Phillips and Valley Conties). Helena. 40pp each.

Montana Deparment of Fish and Game. 1978a. 1978 Montana statewide comprehensive outdoor recreation plan (SCORP): a strategic plan for the protection, perpetuation, and use of Montana's wildlife, fish and recreational resources. Helena. 306pp.

- 1978b. 1978 Montana state-wide comprehensive outdoor recreation plan (SCORP): outdoor recreation inventory, Vol. 2. Helena. 167pp.

- 1978c. Missouri River-Fort Peck Reservoir paddlefish study. Helena, MT. 19pp.

Montana Department of Fish, Wildlife and Parks. 1979. Pages 129166 in Montana deer studies. Federal Aid Proj.W-120-R. Helena, MT.

Montana Department of Highways. 1977-1978. Comparative automatic traffic recorder data. Helena. (unpaged).

Montana Fish and Game Commission. 1973. Montana statewide outdoor recreation plan - an information base, Vol. 2. Helena. (unpaged). 
- 1975. Montana historic preservation plan, with historic sites compendium, Vols. 1-3. Helena. (unpaged).

Moore, G. C. and A. M. Pearson. 1941. The mourning dove in Alabama. Alabama Cooperative Wildlife Research Unit, Wetynyska. 35pp.

Moore, R. 1966. Suitability of grazing enclosures for deer and livestock research on the Kerr Wildlife Management Area, Texas. J. Wildl. Mgmt. 30(1):151-162.

- 1978. Personal communication. Professor of Zoology, Mont. State Univ., Bozeman, MT.

Mueggler, W. R. 1965. Cattle distribution on steep slopes. J. Range Mgmt. $\quad 18: 255-257$.

Murdock, S. H. and T. K. Ostenson. 1976. Population projections by age and sex, 1975-2000. Statistical Series, Issues 23, 30, 31. North Dakota State Univ., Fargo. $64 \mathrm{pp}$.

Murie, O. J. 1935. Report on the Fort Peck Migratory Bird refuge. Unpub1. rept. Lewistown, MT. 33pp.

Musseh1, T. W. and F. W. Howel1 (eds.). 1971. Game management in Montana. Mont. Dept. of Fish and Game, Helena. 238pp.

National Association of Conservation Districts. 1977. Inventory of private recreation facilities. Wash., D.C. 155pp.

Nelson, H. K. 1972. Wetlands and waterfowl relationships. Presented to the Water Bank Advisory Board, Dept. of Agric., Wash., D.C. 12pp.

Nelson, J. R. and D. G. Burne11. 1975. E1k-cattle competition in Central Washington, pages 71-83 in Range Short Course Proc. Coop. Ext. Serv., Oregon State Univ., Corvallis; Wash. State Univ., Pullman; Univ. of Idaho, Moscow.

- 1978. Personal communication. Assoc. Professor of Wild1. Habitat Mgmt., Wash. State Univ., Pullman.

Nielson, L. S. 1978. The effects of rest-rotation grazing on the distribution of sharp-tailed grouse. M.S. Thesis, Mont. State Univ., Bozeman. 52pp.

North Dakota State Outdoor Recreation Agency. 1975. 1975 North Dakota SCORP, state comprehensive outdoor recreation plan. Mandan. (unpaged).

Oldemeyer, J. L., V. H. Reid, D. A. Hickey and M. B. Hedrick. 1980. An evaluation of rest-rotation grazing in the Missouri River Breaks on the Charles M. Russell National Wildlife Refuge, Montana. Unpubl. rept. Fort Collins, CO. 77pp. 
Oldendorff, R. R. 1973. The ecology of the nesting birds of prey of northeastern Colorado. U.S. Int. Biol. Prog. Tech. Rept. No. 211. $233 p p$.

Owens, R. A. 1971. The effects of several agricultural regimes upon populations of native passerine birds of an Alberta fescue grassland. M.S. Thesis, Univ. Calgary, Calgary, Alberta.

and M. T. Myres. 1973. Effects of agriculture upon populations of native passerine birds of an Alberta fescue grassland. Can. J. Zool. 51:697-713.

Owensby, G., E. Smith and K. Anderson. 1973. Deferred rotation grazing with steers in the Kansas Flint Hills. J. Range Mgmt. 26(6):393-395.

Page, J. L., N. Dodd, T. Osborne and J. Carson. 1978. The influence of livestock grazing on nongame wildlife. Cal-Neva Wildl.

Pakulak, A. J. 1969. Nesting ecology of Canada geese of the Churchill area, northern Manitoba. M.S. Thesis, Colo. State Univ., Fort Collins. $134 \mathrm{pp}$.

Papez, N. J. 1976. The Ruby-Butte Deer Herd. Nevada Fish and Game Dept. Bio1. Bul1. No. 5. Las Vegas. 61pp.

Parks Canada. 1978a. Waterton Lakes National Park, park management plan. Calgary, Alberta. 74pp.

- 1978b. Waterton Lakes National Park, Waterton visitor

centre. Calgary, Alberta. (unpaged).

Patterson, R. L. 1952. The Sage Grouse in Wyoming. Sage Books Inc., Denver, Co. $341 \mathrm{pp}$.

Pearson, H. A. 1975. Herbage disappearance and grazing capacity determinations of southern pine bluestem range. J. Range Mgmt 28(1):7173.

Peck, J. M., R. A. Riggs and J. L. Lauer. 1979. Evaluation of fall burning on bighorn sheep winter range. J. Range Mgmt. 32(6):430-436.

Perry, C. and R. Overly. 1977. Impact of roads on big game distribution in portions of the Blue Mountains of Washington, 1972-1973. Bull. No. 11, Wash. State Game Dept., Olympia. 38pp.

Peterson, J. G. 1970. The food habits and summer distribution of juvenile sage grouse in central Montana. J. Wildl. Mgmt. 34:147-155.

Planz, T. 1979. Personal communication. Wildl. biologist, Fish and Wild1. Serv., Bowdoin NWR, MT. 
Prodgers, R. 1979a. Forest resource management on the Charles M. Russell National Wildlife Refuge. Unpubl. rept, Lewistown, MT . (unpaged).

- 1979b. Habitat improvement on the Charles M. Russell

National Wildlife Refuge: shrubs. Unpubl. rept., Lewistown, MT. $19 \mathrm{pp}$.

Pyrah, P. and P. Schladweiler. 1979. Coyote densities, small mammal population indices, and big game fawn production and survival in the various study areas. Job Prog. Rept., Proj. W-120-R-10. Helena, MT. $28 \mathrm{pp}$.

Pyrah, D. 1978. Personal communication. Research biologist, Mont. Dept. of Fish, Wildl. and Parks, Lewistown, MT.

- 1979. The effect of coyotes on big game populations in

Montana. Job Proj. Rept., W-120-R-10. Helena. 28pp.

Range Term Glossary Committee. 1974. A glossary of terms used in range management. Denver, CO. 36pp.

Robbins, C. S., B. Bruun and H. S. Zim. 1966. A guide to Field Identification of Birds in North America. Golden Press, New York. $340 \mathrm{pp}$.

Rogers, J. 1978. Personal communication. Soil scientist, Soil Conservation Serv., Bozeman, MT.

Rollings C. T. 1945. Habits, foods and parasites of the bobcat in Minnesota. J. Wild1. Mgmt. 9(2):131-145.

Roset, A. I. 1957. Notes on the American sparrow hawk. Auk 74(1):119.

Ross, R. L. 1978. Personal communication. Range Conservationist, Soil Conservation Serv., Bozeman, MT.

Rouse, C. H. 1959. Antelope range relationships. Trans. Inter. Antelope Conf. 10:4-9.

Sampson, F. W. 1967. Missouri bobcats. Missouri Conservation. $28(8): 6-7$.

Saskatchewan Tourism and Renewable Resources. 1976. Brochure on Wood Mountain Historic Park. Prince Albert. 24pp.

- 1977. Saskatchewan Trave1 Guide. Regina. 48pp.

- 1978. 1975 survey of sport fishing in Saskatchewan.

Prince Albert. 26pp. 
- Undated.(a) Report of hunter and game population surveys.

Saskatchewan. 92pp.

- Undated.(b) Visitation report, 1977, provincial recreation development areas. Prince Albert. 39pp.

Sather, J. H. 1958. Biology of the Great Plains muskrat in Nebraska. Wildl. Monogr. No. 2. 35pp.

Schimke, J. 1975a. Socioeconomic profile, Northeastern Montana region. Bureau of Land Management, Billings. (unpaged).

- 1975b. Socioeconomic profile, Southeastern Montana region. Bureau of Land Management, Billings. (unpaged).

Schmidt, J. 1979. Reconnaissance geologic and hydrologic report on the Charles M. Russell National Wildlife Refuge, Montana. Unpubl. rept. Lewistown, MT. 282pp.

Schmidt, R. and V. Feuerstein. 1977. Baiting and treating bighorn sheep with apple pulp. Unpub1. rept. Colo. Div. of Wild1. Fort collins. (unpaged).

Schranck, B. W. 1966. Waterfowl nest sites and predation. M.A. Thesis, Univ. Missouri, Columbia. 104pp.

Severson, K. E. 1966. Grazing capacities and competition of pronghorn antelope and domestic sheep in Wyoming's Red Desert. Ph.D. Thesis, Univ. Wyoming, Laramie. 119pp.

1966. Trees and land use. Great Plains Agricultural

Council Publ. No. 81.

and C. E. Boldt. 1978. Cattle, wildlife and riparian

habitats in the Western Dakota's in Regional Range Symposium: Management and use of Northern Plains rangeland. Bismarck, ND. (unpaged).

Sherwood, G. A. 1968. Factors limiting production and expansion of local populations of Canada geese. Pages 738-785 in G. Schoenfield, (ed.), Canada Goose Management. Dembar Educa. Res. Serv., Madison, WI.

Sisson, L. 1976. The sharp-tailed grouse in Nebraska. Neb. Game and Parks Commission, Lincoln. 88pp.

Skovlin, J. M. 1965. Improving cattle distribution on Western mountain rangelands. Dept. of Agriculture Farmer's Bull. 2212, Wash., D.C. $14 \mathrm{pp}$. 
and R. W. Harris. 1970. Management of conifer woodland grazing resources for cattle, deer, and elk. Pages 75-78 in Proc. XI Inter. Grassland Cong.

, P. J. Edgerton, and R. W. Harris. 1968. The influence of cattle management on deer and elk. Trans. N. Amer. Wildl. Nat. Res. Conf. 33:169-181.

Smith, B. 1979. Guidelines for grazing on Charles M. Russell National Wildlife Refuge. Unpubl. rept., Lewistown, MT. (unpaged).

Smith, C. C. 1940. The effect of overgrazing and erosion upon the biota of the mixed-grass prairie of Oklahoma. Ecology 21:381-397.

Smith, D. G. and J. R. Murphy. 1973. Breeding ecology of raptors in the eastern Great Basin of Utah. Brigham Young Univ. Sci. Bull. Biol. Ser. 18(3):176. Provo.

Smith, J. C. and O. Julander. 1953. Deer and sheep competition in Utah. J. Wild1. Mgmt. $17(2): 101-112$.

Smith, R. J. 1977. Conclusions, pages 117-118 in Improving fish and wildlife benefits in range management. Proc. of a seminar, Fish and Wildl. Serv., Wash., D.C. 118pp.

Snow, C. 1972a. Habitat management series for unique or endangered species. American peregrine falcon. Tech. Note 167. Bureau of Land Management, Denver, CO. 35pp.

- 1972b. Habitat management series for unique or endangered species: black-footed ferret. Tech. Note 168, Bureau of Land Management, Denver, CO. 23pp.

- 1973a. Habitat management series for unique or endangered species. Golden eagle. Rep. No. 7. Bureau of Land Management, Denver, Co. 52pp.

- 1973. Habitat management series for unique or endangered species: S. bald eagle. Tech. Note 171. Bureau of Land Management, Denver, C0. 58pp.

- 1974. Habitat management series for unique or endangered species: Burrowing owl. Tech. Note 250. Bureau of Land Management. Denver, CO. 25pp.

Soil Conservation Service. 1976. National Range Handbook. Wash, D.C. (unpaged).

Soil Survey Staff. 1967. Supplement to soil classification, comprehensive system, 7 th approximation. U.S.G.P.O., Wash., D.C. 
Stark, R. H. 1972. Elk-cattle interrelations on Colockum Creek watershed. M.S. Thesis. Wash. State Univ., Pullman. 87pp.

Steven, D. R. 1966. Range relationships of elk and livestock, Crow Creek Drainage, Montana. J. Wild1. Mgmt. 30:349-363.

Stuewer, F. W. 1943. Raccoons: their habits and management in Michigan. Eco1. Monogr. 13:203-258.

Turner, G. T. 1969. Responses of mountain grassland vegetation to gopher control, reduced grazing and herbicide. J. Range Mgmt. $22(6): 377-383$.

Water Resources Council. 1975. 1972 OBERS projections, regional economic activity in the U.S.: series E population supplement, Agricultural Projections. Vols. 1, 3 and 4, Wash., D.C. 139pp.

VanDerwalker, J. G. 1974. Northern Great Plains resource program, draft report, Vols. 1-10. Denver, CO. and Wash., D.C. (unpaged).

Van Poollen, W. and J. Lacey. 1979. Herbage response to grazing systems and stocking intensities. J. Range Mgmt. 32(4):250-253.

Vorhies, C. T. and W. P. Taylor. 1940. Life history and ecology of the white-throated wood rat, Neotoma albigula hart1y, in relation to grazing in Arizona. Univ. of Arizona, Col1. Tech. Bull. No. 86:453529. Tucson.

Wallestad, R. O. 1971. Summer movements and habitat use by sage grouse broods in central Montana. J.Wild1. Mgmt. 35(1):129-135.

and D. Pyrah. 1974. Movement and nesting of sage grouse hens in central Montana. J. Wild1. Mgmt. 38:630-633.

- 1975. Life history and habitat requirements of sage grouse in central Montana. Mont. Fish and Game Dept., Helena, 66pp.

Watts, C. R. 1979. Personal communication. Wildlife biologist, Mont. Dept. of Fish, Wildl. and Parks, Lewistown.

Weatherill, R. G. and L. B. Keith. 1969. The effects of livestock grazing on an aspen forest community. Alberta Dept. of Lands and Forests, Fish and Wildl. Div. Tech. Bull. 1. Calgary. 31pp.

Wight, J., E. Neff and R. Soiseth. 1978. Vegetation response to contour furrowing. J. Range Mgmt. 31(2):97-101.

Wirth, R. L. 1976. Perspectives on the economic base and future of Lewistown, Montana. Great Falls Federal Savings and Loan Assoc. Great Fal1s, MT. 7pp. 
Wittinger, W. T. 1978. Habitats, food habits and range use of mule deer, elk and cattle on the Herd Creek rest-rotation grazing system, east fork of the Salmon River, Idaho. M.S. Thesis, Univ Idaho, Moscow. 125pp.

Young, S. P. 1968. The Bobcat of North America. The Stackpole Co., Harrisburg, PA and the Wildl. Mgmt. Instit., Wash., D.C. 193pp.

Young, V. A. and G. F. Payne. 1948. Utilization of "key" browse species in relation to proper grazing practices in cutover western white pine lands in northern Idaho. J. Forestry 46(1):35-40.

Zacek, J. D., H. E. Hunter, T. A. Brown, and R. L. Ross. 1978. Montana Grazing Guides. Bozeman. 74pp. 


\section{CONSULTATION AND COORDINATION}

Public participation during this EIS process began in 1977 when a group with diverse interests and backgrounds in natural resources toured the refuge and provided management recommendations. A steering committee was established with members comprised of representatives from BLM, MDFW\&P, COE, MDSL, FWS and Montana State Department of Natural Resources. This steering committee has been involved throughout the planning and EIS process.

Public meetings were held in several Montana cities in April 1978 to determine significant issues on the refuge and to get public involvement in formulating long range goals for the refuge. Additional meetings were held by COE in June 1979 and joint meetings involving both COE and FWS were held in September 1979 to obtain public participation immediately prior to EIS preparation. Additional agency and public participation will be obtained as part of the formal EIS review process.

The EIS has been provided to several agencies and organizations, many of whom have already contributed substantially to its preparation (Table 17). Additionally, 950 copies have been sent to legislators, interested individuals, media and local libraries.

Table 17. Agencies and organizations which received draft copies of the Management of Charles M. Russell National Wildlife Refuge, Montana Environmental Impact Statement for review.

Agencies

Federal

Advisory Council on Historic Preservation

Department of Agriculture

Farmers Home Administration

Forest Service

Soil Conservation Service

Department of Commerce

Economic Development Administration

Maritime Administration

National Marine Fisheries Service

National Oceanic and Atmospheric Administration

Department of Defense

Corps of Engineers

Department of Health, Education and Welfare

Center for Disease Control

Public Health Service

Department of Housing and Urban Development

Department of Interior

Bureau of Indian Affairs

Bureau of Land Management

Bureau of Mines

Geological Survey

Heritage Conservation and Recreation Service 
Table 17. (Cont'd.)

National Park Service

Water and Power Resources Service

Department of Transportation

Coast Guard

Federal Aviation Administration

Federal Highway Administration

Federal Railroad Administration

Environmental Protection Agency

Federal Energy Regulatory Commission

Federal Power Commission

Missouri River Basin Commission

old West Regional Committee

State and local

Big Sandy Conservation District

Blaine County Conservation District

Box Elder Conservation District

Broadwater Conservation District

Cascade County Conservation District

Chouteau County Conservation District

Culberson-Bainville Conservation District

Daniels County Conservation District

Dawson County Conservation District

Fergus County Commissioners

Fergus County Conservation District

Froid Conservation District

Gallatin Conservation District

Garfield County Commissioners

Garfield County Conservation District

Glasgow Chamber of Commerce

Hill County Conservation District

Jefferson Valley Conservation District

Lewistown Chamber of Commerce

Liberty County Conservation District

Little Beaver Conservation District

Lower Musselshell Conservation District

Madison Conservation District

McCone Conservation District

McCone County Commissioners

Meagher County Conservation District

Mile High Conservation District

Montana Association of Conservation Districts

Montana Bureau of Mines and Geology

Montana College of Mineral Science and Technology

Montana Cooperative Fishery Research Unit

Montana Cooperative Wildlife Research Unit

Montana Department of Agriculture

Montana Department of Community Affairs 
Table 17. (Cont'd.)

Montana Department of Fish, Wildlife and Parks

Montana Department of Health and Environmental Science

Montana Department of Highways

Montana Department of Natural Resources and Conservation

Montana Department of State Lands

Montana Energy office

Montana Energy Planning Division

Montana Engineering Bureau

Montana Environmental Quality Council

Montana Forestry Division

Montana Historical Society

Montana Office of Commerce

Montana Resources and Planning Bureau

Montana State Clearing House

Montana State Department of Health

Montana State University

Montana Water Resources Division

Montana Water Rights Bureau

Park Conservation District

Petroleum County Commissioners

Petroleum County Conservation District

Phillips Conservation District

Phillips County Commissioners

Pondera County Conservation District

Richland County Conservation District

Rosebud County Conservation District

Sheridan County Conservation District

Stillwater Conservation District

Sweet Grass Conservation District

Toole County Conservation District

Treasure Conservation District

Upper Musselshell Conservation District

Utah Department of Natural Resources

Valley County Commissioners

Valley County Conservation District

Wibaux Conservation District

Yellowstone Conservation District

Non-government organizations

American Farm Bureau

American Fisheries Society

American Forestry Association

American League of Anglers

American Waterways Operator

Atlantic States Marine Fisheries Commission

Center for the Public Interest

Citizens Committee on Natural Resources

Coalition of American Rivers 
Table 17. (Cont' $\left.{ }^{\prime} \cdot\right)$

Committee for Humane Legislation

Conservation Foundation

Defenders of the Outdoor Heritage

Defenders of Wildlife

Ducks Unlimited

Environmental Defense Fund

Environmental Information Center

Fort Peck Forward Committee

Friends of Animals

Friends of the Earth

Fund for Animals

Garfield-McCone Legislative Association

General Federation of Women's Clubs

Humane Society of the United States

International Association of Fish and Wildlife Agencies

Izaak Walton League of America

Monitor, Inc.

Montana Association of Conservation Districts

Montana Audubon Council

Montana Farm Bureau

Montana Farmers Union

Montana Public Lands Council

Montana Stock Growers Association

Montana Wilderness Association

Montana Wilderness Federation

Montana Wilderness Society

National Association of Conservation Districts

National Audubon Society

National Cattlemen's Association

National Farmers Union

National Fisheries Institute

National Livestock and Meat Board

National Parks and Conservation Association

National Rifle Association

National Wildlife Federation

National Wildlife Refuge Association

Natural Resources Council of America

Natural Resources Defense Council

Nature Conservancy

Northern Plains Resource Council

Northern Rockies Action Group

Outdoor Writers Association of America

Public Lands Institute

Recreational Vehicle Industry Association

Resources for the Future

Saskatchewan Natural History Society

Sierra Club

Society of America Foresters 
Table 17. (Cont.d)

Society for Range Management

Sport Fishing Institute

Trout Unlimited Montana Council

Valley County Development Association

Western Montana Fish and Game Association

Wilderness Society

Wildlife Management Institute

Wildlife Society

World Wildlife Fund 


\section{APPENDICES}

Appendix 1. Section 7 evaluation, Charles M. Russell National Wildife Refuge, Montana.

Alternatives in this EIS may affect one to three endangered species: black-footed ferrets, peregrine falcons and bald eagles. Section 7 of the Endangered Species Act states that all federal agencies shall consult with the Secretary of the Interior on the following items: 1) review and utilize existing programs to further the purposes of the act, 2 ) carry out programs for the conservation of endangered or threatened species and 3) ensure that their actions do not jeopardize such species or result in modification or destruction of their critical habitat.

This consultation involves filling out standard Section 7 forms. These forms are then forwarded through administrative channels. Actions that are determined not to affect endangered species can be retained by the regional office or forwarded to Washington. Actions that may affect endangered species are sent to Washington for review. Actions determined to have a significant adverse or beneficial effect on endangered species are referred to the Director of FWS for his decision to ensure that they and their habitats receive full consideration. The following forms are the first step in this Section 7 process.

\section{No Action alternative}

1. Region: 6

2. Designation: $\frac{6-1-80-C}{(\text { region-area-FY) }}$

3. Program(s): refuges and wildlife (R\&W), CMR

4. Listed species or their critical habitats considered: Species are the same within the action area and adjacent to the action area. Black-footed ferret, American peregrine falcon and bald eagle.

5. Name and description: Charles M. Russell National Wildlife Refuge Environmental Impact Statement.

6. Location: Charles M. Russell National Wildlife Refuge, Montana.

7. Objectives of the action:

a. Maintain habitat for black-footed ferrets.

b. Monitor peregrine falcon use of wintering areas near Fort Peck. c. Maintain existing migration habitat for bald eagles.

8. Explanation of impacts of action on listed species or their critical habitats (attach supporting biological data):

a. None. No ferrets are known to occur and their habitat is secure. 
Appendix 1. (Cont'd.)

b. None. Current use is by migrants that utilize migrating ducks and small passerines as a food source.

c. None.

9. Conclusion:

Black-footed ferret

American peregrine falcon

Bald eagle

May Affect

Will Not Affect

$\mathrm{X}$

$\mathrm{X}$

$\mathrm{X}$

10. Recommendation (including action modification):

Continue monitoring existing use by peregrine falcons and bald eagles.

\section{Proposed Action alternative}

1. Region: 6

2. Designation: $\frac{6-1-80-\mathrm{C}}{(\text { region-area-FY) }}$

3. Program(s): R\&W, CMR

4. Listed species or their critical habitats considered:

Species are the same within the action area and adjacent to the action area.

Black-footed ferret, American peregrine falcon and bald eagle.

5. Name and description: Charles M. Russell National Wildlife Environmental Impact Statement.

6. Location: Charles M. Russell National Wildlife Refuge, Montana.

7. Objectives of the action:

a. Maintain habitat for and reintroduce a minimum of six pairs of black-footed ferrets on six or more prairie dog towns as soon as ferrets are available.

b. Reintroduce peregrine falcons and maintain two peregrine falcon eyries by 1985 and a third by 2000 .

c. Maintain existing migration habitat for bald eagles and determine feasibility of establishing a breeding population on CMR.

8. Explanation of impacts of action on listed species or their critical habitats (attach supporting biological data).

a. Black-footed ferrets could be managed, protected and propagated on CMR. Their habitat, prairie dog towns, would remain static or increase slightly to fulfill the ferrets' habitat requirements. 
Appendix 1. (Cont'd.)

b. Peregrine falcons would be managed, protected and propagated. CMR would provide an excellent area to reintroduce them. Habitat for nesting would not change but peregrines' food sources would be increased as a result of more residual ground cover which would allow more ground nesting passerines.

c. If areas are identified, management actions could be taken to enhance bald eagle nesting.

9. Conclusion:

Black-footed ferret

American peregrine falcon

Bald eagle

Will Not Affect

10. Recommendation (including action modification):

Accomplish objectives by the year 2000 .

\section{Intensive Wildlife Management alternative}

1. Region: 6

2. Designation: $\frac{6-1-80-\mathrm{C}}{(\text { region-area-FY) }}$

3. Program(s): R\&W, CMR

4. Listed species or their critical habitats considered:

Species are the same within the action area and adjacent

to the action area.

Black-footed ferret, American peregrine falcon and bald eagle.

5. Name and description: Charles M. Russell National Wildlife

Refuge Environmental Impact Statement.

6. Location: Charles M. Russell National Wildlife Refuge, Montana.

7. Objectives of the action:

a. Maintain habitat for and reintroduce a minimum of six pairs of black-footed ferrets on six or more prairie dog towns as soon as ferrets are available.

b. Reintroduce peregrine falcons and maintain two peregrine falcon eyries by 1985 and a third by 2000 .

c. Maintain existing migration habitat for bald eagles and determine feasibility of establishing a breeding population on CMR.

8. Explanation of impacts of action on listed species or their critical habitats (attach supporting biological data): 
Appendix 1. (Cont'd.)

a. The black-footed ferret, as an endangered species, could be managed, protected and propagated on CMR. Their habitat, prairie dog towns, would remain static or decrease slightly.

b. The peregrine falcon would be managed, protected and propagated. CMR would provide an excellent area to reintroduce the species. Habitat for nesting would not change but the peregrines' food source would be increased as a result of more residual ground cover which would allow more ground nesting passerines to be available as a food source.

c. Cottonwood trees could be planted to provide nesting sites along the shoreline on Fort Peck Reservoir in protected bays and given special attention (protection, water, shade, fence) until they are 5-10 years old. The annual fluctuation in reservoir levels may prevent trees from becoming established. Cattle use may destroy the trees before they become established. Artificial nesting structures could be used until the trees are tall enough.

9. Conclusion:

Black-footed ferret

American peregrine falcon

Bald eagle

May Affect

$\mathrm{X}$

$\mathrm{X}$

$\mathrm{X}$

10. Recommendation (including action modification): Accomplish objectives by the year 2000 .

Multiple Use alternative

1. Region: 6

2. Designation: $\frac{6-1-80-C}{(\text { region-area-FY) }}$

3. Program(s): R\&W, CMR

4. Listed species or their critical habitats considered: Species are the same within the action area and adjacent to the action area.

Black-footed ferret, American peregrine falcon and bald eagle.

5. Name and description: Charles M. Russell National Wildlife Refuge Environmental Impact Statement.

6. Location: Charles M. Russell National Wildlife Refuge, Montana. 
Appendix 1. (Cont' 'd.)

7. Objectives of the action:

a. Maintain habitat for and reintroduce one pair of black-footed ferrets on one of the larger prairie dog towns at UL Bend as soon as ferrets are available.

b. Reintroduce peregrine falcons and maintain two peregrine falcon eyries by 1985 and a third by 2000 .

c. Maintain existing migration habitat for bald eagles.

8. Explanation of impacts of action on listed species or their critical habitats (attach supporting biological data):

a. Only one pair of ferrets could be maintained under this option because prairie dog control would be carried out as needed.

b. Peregrine falcons would be managed, protected and propagated. CMR would provide an excellent area to reintroduce the species. Habitat for nesting would not change but the peregrines' food source would be decreased as a result of less residual ground cover which would allow fewer ground nesting passerines to be available as a food source.

c. None.

9. Conclusion:

Black-footed ferret

American peregrine falcon

Bald eagle

May Affect
X
X

Will Not Affect

$\mathrm{X}$

10. Recommendation (including action modification):

Accomplish objectives by the year 2000. Modify grazing

in areas of proposed introduction of ferrets and falcons

so as not to adversely affect each specie's food base.

No Grazing alternative

1. Region: 6

2. Designation: $\frac{6-1-80-\mathrm{C}}{(\text { region-area-FY) }}$

3. Program(s): R\&W, CMR

4. Listed species or their critical habitats considered:

Species are the same within the action area and adjacent to the action area.

Black-footed ferret, American peregrine falcon and bald eagle.

5. Name and description: Charles M. Russell National Wildlife Refuge Environmental Impact Statement. 
Appendix 1. (Cont'd.)

6. Location: Charles M. Russell National Wildlife Refuge, Montana.

7. Objectives of the action:

a. Maintain habitat for and reintroduce a minimum of six pairs of black-footed ferrets on six or more prairie dog towns as soon as ferrets are available.

b. Reintroduce peregrine falcons and maintain two peregrine falcon eyries by 1985 and a third by 2000 .

c. Maintain existing migration habitat for bald eagles and determine the feasibility of establishing a breeding population on CMR .

8. Explanation of impacts of action on listed species or their critical habitats (attach supporting biological data):

a. The black-footed ferret, as an endangered species, would be managed, protected and propagated on CMR . Their habitat, prairie dog towns, would decrease slightly because no grazing would occur to help retard vegetative growth around dog towns.

b. The peregrine falcon would be managed, protected and propagated. CMR would provide an excellent area to reintroduce the species. Habitat for nesting would not change but the peregrines' food source would be increased as more residual ground cover is provided to enhance habitat values for such prey as passerine birds.

c. If areas are identified, management actions could be taken to enhance bald eagle nesting.

9. Conclusion:

Black-footed ferret American peregrine falcon Bald eagle

May Affect $\mathrm{X}$

$\mathrm{X}$

$\mathrm{X}$

10. Recommendation (including action modification): Accomplish objectives by the year 2000 . 
Appendix 2. Habitat evaluation procedures and values on Charles M. Russell National Wildlife Refuge, Montana.

\section{INTRODUCTION}

The habitat evaluation procedures (HEP) used in this document originated with FWS to gather information for planning and decision making. Data on habitat needs of various indicator species were collected from scientific publications, documented research findings, field notes and professional judgments. Through this process of documentation the best information available on species habitat needs was compiled. This data base is subject to change as new information becomes available but existing knowledge provides a sound scientific basis from which to proceed.

The system of analysis evaluates criteria on a scale of 1 to 10 with 10 being an ideal condition. Because habitat evaluation criteria are derived from locations with varying climates and soils, the criteria value of 10 may not be possible to obtain on CMR. Average annual precipitation on CMR is only 10-13 inches and soils are largely Bearpaw shales, which have low production potential. It is important to keep these limitations in mind when considering the evaluation criteria.

\section{METHODOLOGY}

The refuge was flown in June and July 1977 to obtain color infrared (CIR) photos at a scale of $1: 24000$. These photos were interpreted to determine vegetative types (Appendix Table 2-A). One criterion for habitat evaluation is that information about a species has to be available. The literature was not definitive for all vegetative breakdowns and certain types were combined into the following categories for evaluation: sagebrush-greasewood-grasslands, ponderosa pine-juniper and grassland-deciduous shrub. Other vegetative types listed were deciduous river bottoms and cultivated lands. Ponds were considered portions of major vegetative types in which they occurred.

Representative species were selected for these five vegetative types based on the following factors: 1) information available on habitat requirements, 2) a good indicator of habitat quality and/or represents a group of other species and 3) economically important.

Individual sample sites were selected from a table of random numbers. Two digit numbers were selected corresponding to ranges and townships. All habitat types within the selected section were sampled. Additional samples were taken as time permitted to increase sampling reliability. At each sample site the following information was listed: 1) unit numbers, 2) general vegetative type, 3) date, 4) legal description, 5) subtype and 6) evaluator's name. Each habitat component was rated on a scale of 1-10 (10 being the best and 1 the worst). Criteria with interval values of $1,4,7$ and 10 are described in Appendix Tables 2-B through 2-G for the seventeen species sampled. 
Appendix 2. (Cont'd.)

Assignment of values 1-10 for individual criteria was based on a combination of observations and actual measurements. Periodic measurements were taken to verify observations, thus maintaining confidence in evaluation. Then two overall values were listed. The first was a biological judgment from the evaluating team and the second was the numerical average of the listed criteria. If differences of more than 2.5 units existed between the two overall values, reasons for this were documented on the field sheets. The two values were generally comparable. Where discrepancies occurred, ratings were modified based on both the actual rating and the biologist's comments. The total number of sample values was averaged for each species by individual criteria and overall value for respective vegetative types. For example, in the sage-greasewood-grassland, all mule deer values for condition of browse were summed and divided by the number of samples to get a value of 4.9 (Appendix Table 2-C). In the same manner all overall mule deer values in this type were summed and divided by the number of samples to get a value of 4.7 .

The terms poor, fair, good and excellent are referred to through the narrative in relation to HEP criteria. The four terms indicate the following range of HEP values: poor, 1.0-2.5; fair, 2.6-5.0; good, 5.1-7.5 and excellent, 7.6-10.0.

These terms could be applied to individual criteria or overall values. If a species was evaluated in more than one vegetative type a weighted average was derived based on the percentage of the respective habitat type in which the species was found. For example, in the ponderosa pine-juniper type, the overall value for sharp-tailed grouse was 4.5 and in the grassland deciduous shrub type it was 5.6. The ponderosa pine-juniper type occupies approximately 35 percent of the refuge while the grassland-deciduous shrub type occupies about 2 percent of the area. Since the ponderosa pine-juniper type covers about 17 times more area, the value used for sharp-tailed grouse was derived as follows:

$$
\begin{aligned}
\text { Sharp-tailed grouse value } & =\frac{(4.5 \times 17)+(5.6 \times 1)}{18} \\
& =4.56 \\
& =4.6 \\
& =\text { fair }
\end{aligned}
$$


Appendix 2. (Cont'd.)

Appendix Table 2-A. List of vegetative types on Charles M. Russell National Wildlife Refuge, Montana.

1. Big sagebrush-grassland

2. A. Silver sagebrush bottomlands

B. Silver sagebrush - sandy upland sites

3. Ponderosa pine

4. Douglas fir

5. Juniper

6. Deciduous river bottoms (includes ash coulees)

7. Grassland

8. A. Tall shrubs - buffaloberry

B. Shorter shrubs - rose and snowberry

9. Halophytic shrubs

A. Greasewood bottomlands

B. Greasewood-grasslands

C. Shadscale

10. Cultivated lands

A. Hayland

B. Dryland

11. Barren areas 
Appendix 2. (Cont'd.)

Appendix Table 2-B. Sagebrush-grassland vegetative type on Charles M. Russell National Wildlife Refuge, Montana.

Sage grouse habitat criteria and rating values

-10- Interspersion of grass and sage with areas of dense big sage (20-39 percent canopy cover) for use by adults throughout the year (Wallestad 1971, Eng and Schladweiler 1972). Areas of moderate big sage (10-15 percent) for use by broods (Wallestad 1971 and Klebenow 1969). Sage 10-24 inches in height for use throughout the year (Dalke et a1. 1963, Martin 1970, Wallestad 1971). Ground cover has 10-15 percent canopy cover for forbs in spring and summer (professional judgment). Water within 1 mile (professional judgment and inference by Patterson 1952).

-7- Interspersion of dense and moderate big sage for adults and broods as above. Sagebrush is 6-16 inches high. Forbs comprise less than 10 percent of ground cover in spring and summer. Water $1-1.5$ miles away.

-4- No interspersion of dense big sage and moderate big sage. Sage less than 12 inches in height. Forbs comprise less than 5 percent of the ground cover in summer. Alfalfa fields available within the area (professional judgment). Water 2-3 miles.

-1- Big sage brush very scattered and less than 10 inches tall. Forbs almost nonexistent. Alfalfa fields heavily used. Water greater than 3 miles away.

Golden eagle habitat criteria and rating values

-10- Large tracts (1000 acres or larger) of sage-grassland for hunting (McGahan 1968). Cliffs and/or rock outcrops for nesting (Snow 1973, Boecker and Ray 1971). Perch sites available in the form of snags and/or rock outcrops (Jackman and Scott 1975). Sage-grassland with a mixture of sage and grass species that provide cover for rodent populations (professional judgment). No human disturbance within 1 mile (Snow 1973, Fish and Wildlife Service 1976, Boecker and Ray 1971).

-7- Tracts of sage-grassland 500-1000 acres in size. Rock outcrops are more limited, but some large cottonwoods occur for nesting. Sage-grassland lacks good mixture of sage and grasses resulting in smaller rodent populations. Human disturbance within $1 / 2$ mile of nest. 
Appendix Table 2-B. (Cont'd.)

-4- Small tracts of sage-grassland (250-500 acres) located adjacent to ponderosa pine forest. Sage-grassland lacks rock ledges for nesting and perching. Ponderosa pine provides some nest sites. Sage-grassland has vegetation less than 8 inches tall resulting in poor cover for rodents. Human disturbance within $1 / 4$ mile.

-1- Sage-grassland is less than 250 acres in size. No nest sites available in the sage-grassland. Sage-grassland vegetation is less than 5 inches high. Continual human disturbance occurs.

Pronghorn habitat criteria and rating values

-10- Sage-grassland with a mixture of big sage, silver sage, snowberry, rose and rabbitbrush (Couey 1946). Succulent forbs available in spring and summer (Hoover et al. 1959). Silver sage abundant in coulee bottoms and adjacent benches for feeding in winter (D. Pyrah personal communication). Sagebrush canopy cover of 10-24 percent for use throughout the year, and 20 percent or greater for fawning (Bayless 1969, D. Pyrah personal communication). Rolling terrain marked by depressions, ridges, flats, benches and some breaks (Rouse 1959, Hoover et al. 1959). Sagebrush 1-1.5 feet tall (Einarsen 1948, and Severson 1966).

-7- Sage-grassland with 2-3 species of shrubs as listed above. Forbs available in spring. Silver sage less abundant than above. Sage canopy cover is a maximum of 15 percent for all uses. Sage less than 1 foot tall. Terrain is gently rolling but without depressions and breaks.

-4- Sage-grassland of mostly big sage. Forbs available in wet years. Alfalfa fields used in summer (Cole 1956). Silver sage very restricted for winter use. Sagebrush canopy cover is 10 percent or less for all seasons of use. 1.5-2 feet tall. Terrain quite flat; lacking little if any topographic relief.

-1- Rank growth of sagebrush over three feet in height or sage extremely sparse. Terrain extensively flat.

Mule deer habitat criteria and rating values

-10- Big sage, rubber and green rabbitbrush abundant for winter use (Mackie 1970). Species are in good-excellent condition with little or no hedging (Mackie 1970). Forbs, such as wild onion, biscuitroot and especially yellow sweet clover available 
Appendix Table 2-B. (Cont'd.)

in summer and fall (Mackie 1970). Other shrubs present include skunkbrush, rose, snowberry and creeping juniper (may include some Rocky Mountain juniper) (Mackie 1970, Allen 1968). Topographic relief in the form of cuts, ravines and/or juniper patches for hiding cover (professional judgment). Land is deeply dissected (professional judgment).

-7- Big sage and rabbitbrushes abundant for winter use. Fairgood condition with some hedging. Same forbs present but yellow sweet clover is restricted for use. Skunkbrush and juniper present. Topographic relief is less pronounced. No deep dissection of the land. Less juniper for hiding cover.

-4- Only big sage present for winter use. It is in fair-good condition with moderate hedging. Few forbs present. Little sweet clover. Scattered skunkbrush. Rolling hills. No deep dissected 1and. Sparse juniper cover.

-1- Scattered sage in poor condition and badly hedged. Very few forbs. No sweet clover. Lack other palatable browse species. Land is flat to gently rolling. No rugged escape cover.

$1=$ poor, $4=$ fair, $7=$ good and $10=$ excellent 
Appendix 2. (Cont'd.)

Appendix Table 2-C. Ponderosa pine-juniper vegetative type on Charles M. Russell National Wildlife Refuge, Montana.

Red-tailed hawk habitat criteria and rating values

-10- Ponderosa pine forest that is open (canopy cover less than 30 percent) (Bent 1937, Jackman and Scott 1975, modified by professional judgment) and adjacent to areas of sage-grassland. Trees 20-30 feet tal1 and 8-10 inches DBH for nesting (Bent 1937, Jackman and Scott 1975, modified by professional judgment). Sage-grasslands has good mixture of sage, grass and forb species as cover for prey population (professional judgment).

-7- Ponderosa pine has 30-45 percent canopy closure. Adjacent sage grassland is 300-400 acres in size. Trees 15-20 feet tal1, 6-7 inches DBH. Sage-grassland in fair condition as cover for prey population.

-4- Ponderosa pine forest having 45-60 percent canopy closure. Adjacent to smaller sage-grassland (less than 300 acres). Trees 10-15 feet tal1 and 4-5 inches DBH. Grassland in good condition, but little or no sagebrush.

-1- Dense ponderosa pine forest (greater than 60 percent canopy cover). No sage-grassland for hunting.

Elk habitat criteria and rating values

-10- Long narrow coulees that are highly dissected and contain mesic sites with dense conifer cover at their head (B. Campbell, personal communication). Dense juniper thickets for calving, hunting security and shade (B. Campbell personal communication). Topographic relief in the form of cuts, ravines, and/or trees for shade and hiding cover (B. Campbell personal communication). Abundant mesic coulees for feeding summer and fall (B. Campbell personal communication). Small to moderately extensive ridgetops dominated by big sagewestern wheatgrass in good-excellent condition for winterspring use (Mackie 1970). Water source every section (B. Campbell personal communication).

-7- $\quad$ Fewer long narrow coulees as above. Less dense juniper thickets. Rolling topography. Some mesic sites and/or yellow sweet clover patches for feeding summer and fall. Ridgetops as above in fair-good condition for winter-spring use. Water source every two sections. 
Appendix Table 2-C. (Cont'd.)

-4- No coulees as above. No juniper thickets. Rolling topography. Few mesic coulees and/or clover patches. Winterspring areas in poor-fair conditions. Water sparsely distributed.

-1- Lack of topographic relief and vegetative cover. Lack of palatable grasses and forbs. Lack of water.

Sharp-tailed grouse habitat criteria and rating values

-10- North slopes with 10-12 inches of effective residual grass cover for nesting (Christenson 1971, Sisson 1976). Shrub crown cover of 30-45 percent in coulees (Grange 1948, Ammann 1957). Shrub coulees with serviceberry, chokecherry, snowberry, wildrose and buffaloberry (Sisson 1976, Nielsen 1978). Shrubs having all terminal leaders alive (professional judgment). Grasses and forbs abundant and in good condition between forest area (Edminster 1954, and professional judgment).

-7- North slopes with 8-10 inches effective residual grass cover. Shrub crown cover 45-60 percent in coulees. Same shrub species. Shrubs with 75 percent of terminal leaders alive. More grasses and less forbs between forest areas.

-4- North slopes have effective residual grass cover of 6-8 inches high. Shrubs in coulees with 20-30 percent crown cover. Some deciduous species present but mostly juniper. Deciduous shrubs somewhat decadent (50 percent of terminal leaders alive). Understory sparsely vegetated.

-1- Residual grass cover less than 6 inches tall. Only juniper present and in good condition. Grading into sage-grassland.

Porcupine habitat criteria and rating values

-10- Ponderosa pine forest with a semi-open canopy (30-60 percent) (Costello 1966 and professional judgment). Trees 7 inches or greater DBH and 15-20 feet high (Marshall et al. 1962). Herbaceous material composes about 50 percent of the ground cover (Costello 1966 and professional judgment). Some heavy brush, rock piles or other suitable dense cover is available within the habitat for denning (Costello 1966).

-7- Ponderosa pine forest with less than 30 percent canopy cover. Herbaceous material composes 25-50 percent of the ground cover. Clumps of dense brush and/or rock outcrops are quite scattered. 
Appendix Table 2-C. (Cont'd.)

-4- Ponderosa pine forest with dense canopy cover (greater than 60 percent). Trees more than 30 feet tall. Less than 25 percent herbaceous ground cover. Single scattered bushes and few rock outcrops.

-1- Dense ponderosa pine forest ground cover is primarily pine needles. No brush or rock outcrops.

Mountain bluètird habitat criteria and rating values

-10- Ponderosa pine forest that has less than 30 percent canopy cover (Jackman and Scott 1975) and two or more snags/acre with cavities for nesting (Balda 1975). Ground cover is less than 2 feet high (Miller 1970).

-7- Ponderosa pine forest with as much as 60 percent canopy cover. Still has several cavities for nesting. Ground cover is up to 3 feet high.

(-6- Juniper present but grass less than 2 feet ta11.)

-4- Ponderosa pine forest with as much as 75 percent canopy closure. Few nesting cavities occur. Ground cover is over 3 feet high.

-1- Closed ponderosa pine forest. Greater than 75 percent canopy cover. No nesting cavities. Heavy shrub understory.

Bobcat habitat criteria and rating values

-10- Forest canopy closure 45-60 percent (professional judgment). Moderate brush understory (difficult to see through but can be walked through) (Sampson 1967). Scattered rock outcrops and ledges (Rollings 1945). This forest may also be adjacent to coulees filled with juniper and sagebrush (Young 1958).

-7- Canopy closure 30-45 percent and forest understory is becoming dense (difficult to walk through). Dense clumps of scattered juniper may also occur.

-4- Open forest, less than 30 percent canopy cover. Light shrub understory. Few rock outcrops. Coulees have little juniper or sage.

-1- Scattered trees. Herbaceous understory. No rock outcrops. 
Appendix Table 2-C. (Cont'd.)

Mule deer habitat criteria and rating values

-10- Interspersion of ponderosa pine with patches of sagegrassland on smaller ridgetops, and along margins of more extensive ridges with sage abundant in these areas for winter use (Mackie 1970). Forbs (especially yellow sweet clover) and skunkbrush available in summer and fall (Mackie 1970). Other shrubs as snowberry, rose and chokecherry also available in summer and fall (Mackie 1970, Allen 1968). Shrubs, including big sage and rubber rabbitbrush, available in winter, in good condition with no hedging (Mackie 1970).

-7- Interspersion of ponderosa pine with patches of sagegrassland along major ridgetops and sage abundant. Yellow sweet clover available in summer. Skunkbrush very sparse. Big sage and rubber rabbitbrush available in winter in fair condition with some hedging.

-4- Interspersion of ponderosa pine with some patches of sagegrassland along major ridgetops and sage scattered. Yellow sweet clover very scarce as is skunkbrush for summer and fall use. Big sage available in winter in poor condition with moderate hedging.

-1- Ponderosa pine on moderate slopes with no sage-grassland interspersed. Few palatable forbs or shrubs as above. Those present are in very poor condition and heavily hedged.

$1=$ poor, $4=$ fair, $7=\operatorname{good}$ and $10=$ excellent 
Appendix 2. (Cont $\left.{ }^{\prime} \mathrm{d}_{\bullet}\right)$

Appendix Table 2-D. Grassland-deciduous shrub vegetative type on the Charles M. Russell National Wildlife Refuge, Montana.

Sharp-tailed grouse habitat criteria and rating values

-10- North slopes with 10-12 inches of effective residual grass cover for nesting (Christenson 1971, Sisson 1976). Shrub coulees of 30-60 percent crown cover (Grange 1948, Ammann 1957) and 6-12 feet high for brooding and roosting (Sisson 1976, Nielsen 1978). Shrubs are mostly serviceberry, chokecherry, snowberry, wild rose and buffaloberry (professional judgment). Grasses and forbs abundant and in good condition between shrub areas (Edminster 1954 and professional judgment).

-7- North slopes with 8-10 inches of effective residual grass cover. Shrub coulees of 45-60 percent crown cover and 6-8 feet high. Same shrub species plus juniper. Deciduous shrubs with 75 percent of terminal leaders alive. More grasses and less forbs, still in good condition.

-4- North slopes with 6-8 inches of effective residual grass cover. Coulees with more scattered shrubs (20-30 percent crown cover). Shrubs 4-6 feet tall. Two-three shrub species present that have 25-50 percent of terminal leaders alive. Understory sparsely vegetated.

-1- North slopes with 3-4 inches of effective residual grass cover. Shrubs very scattered in coulees (less than 10 percent crown cover). One or two species less than 2 feet tall. Shrubs decadent with less than 25 percent of leaders alive.

Mourning dove habitat criteria and rating values

-10- Large grain or weed fields within 1 mile of deciduous shrub area (Edminster 1954, Moore and Pearson 1941). Shrub crown cover 30-60 percent in scattered clumps (professional judgment). Shrub areas with 4 miles of water (McClure 1943).

-7- Only road edges available for feeding. These areas are within 1 mile of shrub areas. Shrub crown cover 10-30 percent in scattered clumps. These areas are up to 5 miles from water.

-4- Only grassland available as seed source. These feeding areas are more than 2 miles from shrub areas. Shrub crown cover is less than 10 percent and these areas are up to $6 \frac{1}{2}$ miles from water. 
Appendix Table 2-D. (Cont'd.)

-1- No seed source. Shrub crown cover less than 5 percent in coulees. Water is $8+$ miles away.

Mule deer habitat criteria and rating values

-10- Shrubby areas with shrubs 5-6 feet high in patches of 800-1600 feet in length for hiding and fawning. (Thomas et a1. 1976). Shrubs for winter food source include juniper, snowberry, rose, chokecherry and sagebrush (Kufeld et al. 1973, Mackie 1970). (These plants have 75 percent or more of current year's growth retained through the winter (professional judgment). Forbs abundant (15 percent of the ground cover) (K. Hamlin personal communication, Kufeld et al. 1973). Topographic relief in the form of cuts, ravines and rolling hills (professional judgment).

-7- Shrubby areas with shrubs 2-6 feet high in patches of 200-800 feet in length for hiding and fawning. Shrubs for winter food are the same as above. These plants retain 50-75 percent of current year's growth through the winter. Forbs 10 percent of the ground cover. Topographic relief is less pronounced, no deep cuts or ravines.

-4- Shrubby areas less than 2 feet in height are quite scattered and smaller than 200 feet in length. Shrubs for winter food include juniper, rose and sagebrush. These species are not abundant and retain 25-50 percent of current year's growth through the winter. Forbs 5 percent of the ground cover. Only gently rolling hills for topographic relief.

-1- No shrub patches large enough to provide hiding cover. Only sagebrush and juniper available for winter food. Few forbs occur. Flat to rolling sage-grasslands.

1 = poor, $4=$ fair, $7=$ good and $10=$ excellent 
Appendix 2. (Cont'd.)

Appendix Table 2-E. Deciduous river bottom vegetative type on the Charles M. Russell National Wildlife Refuge, Montana.

Raccoon habitat criteria and rating values

-10- Deciduous tree stand of large, mature trees within 500 feet of water (professional judgment, Stuewer 1943, Giles 1942). Average height of trees over 55 feet (Stuewer 1943). Average DBH of trees, 25 inches (Stuewer 1943). Denning trees, or their potential, available at rate of $4+$ per $15-20$ acres (Stuewer 1943). Trees within 0.5 mile of cultivated cropland, if available (Caras 1967).

-7- Deciduous trees stand with 20-30 percent large mature trees. Stand within 800 feet of water. Average height of trees 38 feet. Average DBH of trees 18 inches. Denning trees, or their potential, available at rate of 2 per 15-20 acres. Trees 1.25 miles from cultivated cropland, if available.

-4- Young deciduous tree stand. Stand within 1200 feet of water. Average height of trees 20 feet. Average DBH of trees 10 inches. No denning trees available but ground-den sites available.

-1- No trees or just saplings. Over 1600 feet from water. No den sites.

White-tailed deer habitat criteria and rating values

-10- River bottom with overstory of continuous large mature cottonwoods (Musseh1 and Howe11 (ed.) 1971). Shrub understory that is dense and difficult to walk through (professional judgment). Palatable browse species like snowberry, chokecherry, cottonwood, green rabbitbrush, serviceberry, and red osier dogwood present and less than 6 feet tall (Allen 1968). Plants retain 75 percent or more of current year's growth through the winter (Young and Payne 1948). Openings scattered through river bottom (McCaffery and Creed 1969). Coulees of deciduous shrubs within sight of the river bottom (professional judgment). Include bottoms numbered 16-20 from the mouth of the reservoir ( $\mathrm{K}$. Hamlin personal communication and professional judgment).

-7- River bottom with overstory of large mature cottonwoods that are not continuous. Shrub understory that is moderately dense and can be walked through. Three-four palatable browse species (as listed above) within 6 feet of ground level. Plants retain 50-75 percent of current year's growth through the winter. 
Appendix Table 2-E. (Cont'd.)

Occasional openings throughout the river bottom. Include bottoms numbered 11-15 from mouth of the reservoir.

-4- River bottom with cottonwood overstory occurring as clumps of scattered trees. Light shrub understory, one-two palatable browse species as listed above within 6 feet of ground level. Plants retain 25-50 percent of current year's growth through the winter. Agricultural fields adjacent to river bottom. Include bottoms 6-10 from mouth of the reservoir.

-1- River bottom with no overstory, and only very scattered shrubs. Large proportion of annuals compose ground cover. Include bottoms 1-5 from mouth of the reservoir.

Eastern kingbird habitat criteria and rating values

-10- Mature deciduous forest contiguous to river system for perch sites (Manolis 1973). Understory of trees and shrubs 6-10 feet high for nesting (Graber et al. 1974, Davis 1955). These areas are surrounded by open country used for feeding (Graber et a1. 1974).

-7- Shrubs and young trees contiguous to a stream bank. Open country surrounds water system.

-4- Scattered mature deciduous trees contiguous to river system. Lack of shrub-small tree understory. Open country is not nearby.

-1- Shrubby coulees not within site of river bottom. These coulees lack water. Open country is not nearby. 
Appendix 2. (Cont'd.)

Appendix Table 2-F. Cultivated lands vegetative type on the Charles M. Russell National Wildlife Refuge, Montana.

American kestrel habitat criteria and rating values

-10- Agricultural fields adjacent to cottonwood river bottoms (Eyre and Paul 1973). Cottonwoods should be mature with cavities for nesting (Olendorff 1973). Suitable perch sites available. This could include fence posts, power lines, rocks or boulders (Roest 1957).

-7- Agricultural fields adjacent to coulees with ash or cottonwood trees. Trees are mature but not of cavity-bearing size. Perch sites are also more restricted.

-4- Agricultural fields on upland sites adjacent to grasslands and/or ponderosa pine trees without suitable nest sites. Few suitable perch sites occur.

-1- Extensive, rolling grassland. No trees or rock outcrops for nesting or perching.

Mourning dove habitat criteria and rating values

-10- Cultivated fields within 1 mile of coulees containing deciduous shrubs and/or river bottoms (Edminster 1954, Moore and Pearson 1941). Shrubby coulees and river bottom forest should be semi-open (30-60 percent canopy cover) (professional judgment). Distance to water is 4 miles or less (McClure 1943).

-7- Cultivated fields within 1 mile of sage-grassland or deciduous shrub coulees. Shrub crown cover is 10-30 percent. Water is up to 5 miles away.

-4- Cultivated fields more than 2 miles from sage-grassland or deciduous shrub coulees. Shrub coulees are quite scattered, and shrub crown cover is less than 10 percent. Water is up to $6 \frac{1}{2}$ miles away.

-1- No cultivated fields. Only very scattered shrubs or trees. Water is 8 miles or more away.

$1=$ poor, $4=$ fair, $7=$ good and $10=$ excellent 
Appendix 2. (Cont'd.)

Appendix Table 2-G. Ponds (evaluated in whatever vegetative type it occurred in) on the Charles M. Russell National Wildlife Refuge, Montana.

Muskrat habitat criteria and rating values

-10- Water level stable throughout the year (Errington 1948, 1963). Water gradually increasing to a maximum depth of 4 feet (Sather 1958, Errington 1948). Emergent vegetation (particularly cattail and bulrush) growing over $1 / 2$ of surface area in a scattered pattern (Errington 1963). Shoreline beyond emergent vegetation completely stable and vegetation 12 inches high (Errington 1963, inference and professional judgment).

-7- Water level fluctuations annual and of one foot or less. Water depth gradually increasing to a maximum of three feet. Emergent vegetation growing on half of the area of just along shoreline. Shoreline stable and in good condition but vegetation short (6-12 inches high).

-4- Water level fluctuations frequent throughout the year and of more than one foot. Water depth 1-2 feet. Emergent vegetation covers 25 percent or less of the surface. Shoreline damaged and/or vegetation very short (less than 6 inches high)。

-1- Water level fluctuation extreme (over 5 feet), resulting in dry and flood conditions which either exposes or inundates lodges and dens or water depth of pond less than 1 foot. No emergent vegetation. Shoreline only bare ground with no vegetation.

General waterfowl habitat criteria and rating values

-10- Pond is at least 5 acres (526 feet in diameter) at low water in late summer (Crissey 1968). Submerged aquatic vegetation covers entire bottom of pond (professional judgment). Emergent vegetation (bulrush and cattail) cover $1 / 2$ surface area of pond in a scattered pattern (professional judgment). Herbaceous upland vegetation, including brush if present, within 150 feet of the pond is $1.5+$ feet tall and $75+$ percent ground cover (Bent 1923, Bennet 1938, Burgess et a1. 1965, Drewien and Springer 1969). Pond contains at least one island for goose nesting (Geis 1956, Sherwood 1968, Pakulak 1969).

-7- Pond is 3.5 acres (440 feet in diameter) at low water in late summer. Submerged aquatic vegetation covers 75 percent of bottom. Emergent vegetation covers $1 / 2$ surface area of pond in mostly a block or band. Herbaceous/brushy upland vegetation 
Appendix Table 2-G. (Cont'd.)

is 1 foot tall and has 60 percent ground cover. Only muskrat houses available for goose nesting.

-4- Pond is 2 acres (332 feet in diameter) at low water in late summer. Submerged aquatic vegetation covers 25 percent of bottom. Emergent vegetation is only around $1 / 2$ of the pond edge. Herbaceous/brush upland vegetation is 6-12 inches tall and has 30 percent ground cover. Peninsula of land for goose nesting.

-1- Pond dries up every summer. Little or no submerged aquatic vegetation present. No emergent vegetation present. Upland vegetation is mostly herbaceous of less than 3 inches height and the shoreline area is bare ground. Only shoreline available for goose nesting.

$1=$ poor, $4=$ fair, $7=\operatorname{good}$ and $10=$ excellent 
Appendix 2. (Cont'd.)

Appendix Table 2-H. Wildlife habitat ratings by major habitat type on Charles M. Russell National Wildlife Refuge, Montana.

\begin{tabular}{lcl} 
Vegetative type, wildife & Individual & criteria \\
species and criteria & rating & $\begin{array}{l}\text { Overall } \\
\text { rating }\end{array}$ \\
\hline
\end{tabular}

Sage-greasewood-grassland

Sage grouse canopy cover of sage sage height canopy cover of forbs distance to water alfalfa fields

4.3

6.4

5.0

8.7

3.8

Golden eagle

tract size

suitable perch/nest sites

cover for rodent population

human disturbance

9.0

5.3

5.3

7.7

\section{Pronghorn}

mixture of shrubs \& grass

forb availability

silver sage availability

sage canopy cover

sage height

topography

4.7

5.6

4.6

5.1

7.5

7.2

Mule deer

winter browse

4.7

condition of browse

4.9

forb-summer \& fall

5.5

other shrubs

5.7

4.9

topography relief

6.3

Ponderosa pine-juniper

Red-tailed hawk

forest canopy cover

8.7

adjacent sage/grassland

9.0

tree size-nesting/perching

7.7

cover for prey

5.1

4.9

E1k

coulee availability

6.5

juniper cover

6.7

topography

7.8

feeding sites

5.5

water availability

8.3 
Appendix Table 2-H. (Cont'd.)

Sharp-tailed grouse

4.5

north slope residual cover

3.8

shrub crown cover

4.1

shrubby coulees

3.9

understory quality

5.2

Porcupine

forest canopy cover

6.2

tree size

ground cover

8.3

denning sites

5.7

6.2

Mountain bluebird

forest canopy cover

nesting cavities

ground cover height

6.0

8.8

5.3

7.5

Bobcat

5.0

forest canopy cover

understory density

5.6

rock outcrops and ledges

4.9

2.5

coulee cover

4.9

Mule deer

interspersion-pine/sage/grass

summer/fall food-forbs and shrubs

winter food-shrubs

Grassland-deciduous shrub

Sharp-tailed grouse

height of shrubs

north slope residual cover

6.0

5.6

shrub crown cover

4.9

shrubby coulees species

5.0

grass/forbs

7.0

7.6

Mourning dove

seed source availability

5.2

shrub crown cover

6.2

distance to water

9.9

Mule deer

6.1

shrub height

shrub patch size

8.6

winter browse species

4.4

6.8

forb abundance

5.6

topography

6.8 


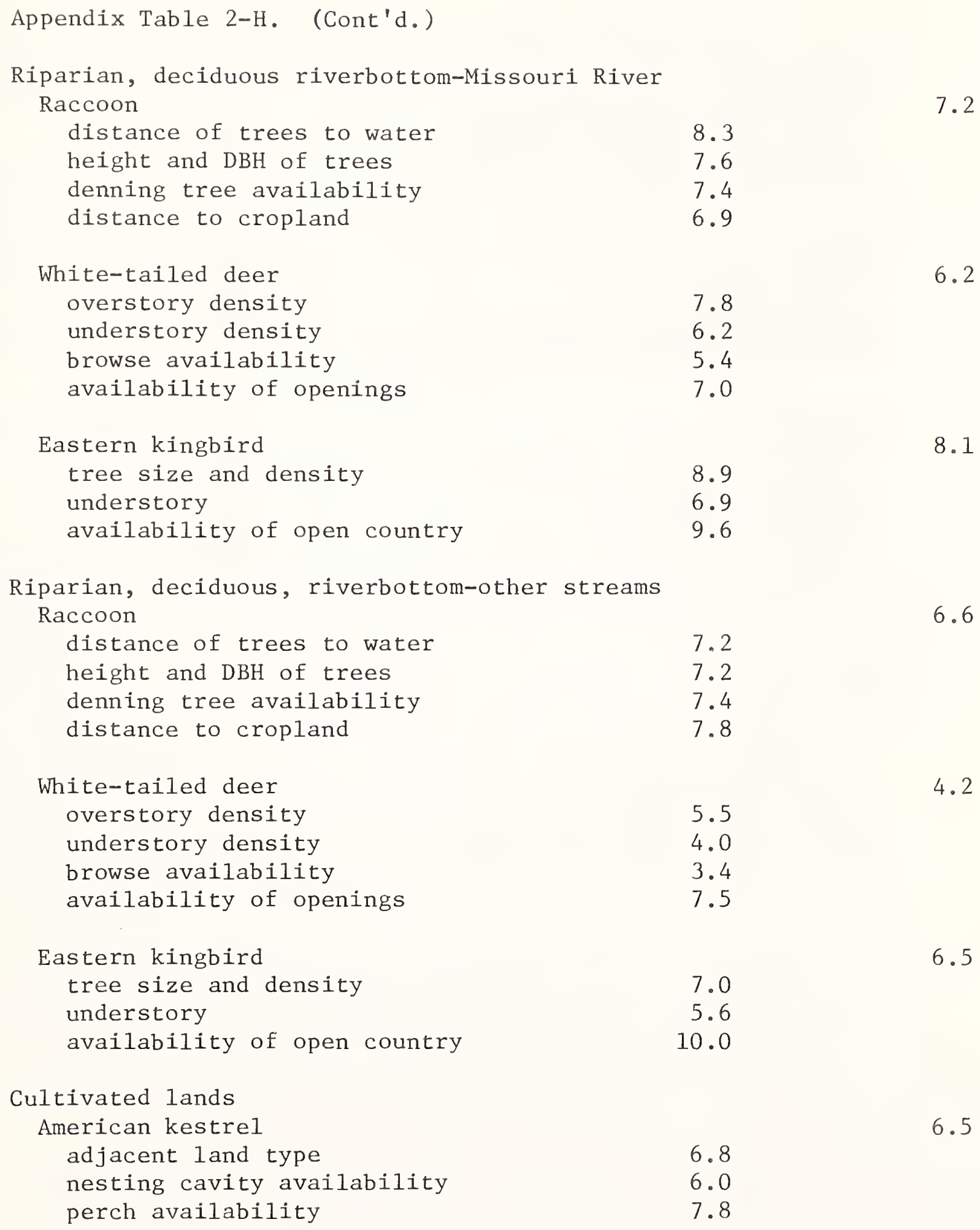


Appendix Table 2-H. (Cont'd.)

\section{Mourning dove}

distance to interspersed land

7.3

canopy cover-forest or shrub

7.9

distance to water

6.6

10.0

\section{Ponds}

Muskrat

water stability

water depth

6.8

emergent vegetation abundance 3.2

shoreline stability and vegetation 4.6

Waterfow1

pond size

3.9

submerged aquatic vegetation

3.2

emergent vegetation

3.0

upland vegetation

3.8

goose nesting sites

3.8

$0.0-2.5=$ poor, $2 \cdot 6-5.0=$ fair, $5 \cdot 1-7.5=\operatorname{good}$ and $7.6-10.0=$ excellent 
Appendix 3. Memorandum of agreement between District Engineer, Omaha District, Corps of Engineers and Area Manager, Billings Area Office, Fish and Wildlife Service for the Charles M. Russell National Wildlife Refuge and Fort Peck Lake Project, Montana.

The US Fish and Wildlife Service and the US Army Corps of Engineers recognize the National, Regional and Local importance of the natural resources contained within the Charles M. Russell National Wildlife Refuge and the Fort Peck Lake Project, Montana, hereinafter called the Area. Both agencies also recognize the public interest can be best served through coordinated planning and management efforts to maximize opportunities for conserving these resources and minimize the adverse impacts associated with the management actions of the respective agencies.

The parties to this Memorandum of Agreement agree to coordinate, cooperate, and, when appropriate, jointly develop resource management plans and other actions.

The Omaha District Engineer of the Corps of Engineers and the Billings Area Manager of the Fish and Wildlife Service will develop mechanisms necessary to insure that implementation of all actions are in consonance with agreements contained herein.

In each phase of planning and future management and in the formulation of proposals for the preservation, conservation, management and/or development of the natural resources within the Area, both agencies will consult and identify potential actions which could have adverse or beneficial impacts on the executive and legislative mandated responsibilities of each agency. Both agencies agree to coordinate efforts at the field operating level to resolve these potential areas of conflict and to modify the potential actions to the extent permitted by each agency's policies and regulations, and applicable laws.

It is further recognized by both agencies that the natural resources in the Area should be made available for public enjoyment and appropriate recreation provided that public use and associated developments do not adversely affect fish and wildlife and their habitats and will be operated in a generally natural setting compatible with the Missouri River Breaks Ecosystem.

Date 17 July 1979

Date 11 July 1979

\author{
(signed) V. D. Stipo \\ V. D. Stipo \\ Col., Corps of Engineers \\ Omaha District Engineer
}


Appendix 4. Executive Order 7509 establishing the Fort Peck Game Range, Montana.

By virtue of and pursuant to the authority vested in me as President of the United States and by the act of June 25, 1910, ch. 421, 36 Stat. 847, as amended by the act of August 24, 1912, ch. 369, 37 Stat. 497, and subject to the conditions therein expressed and to all valid existing rights, it is ordered that the following-described lands, insofar as title thereto is in the United States, be, and they are hereby, withdrawn from settlement, location, sale, or entry and reserved and set apart for the conservation and development of natural wildlife resources and for the protection and improvement of public grazing lands and natural forage resources: Provided, That nothing herein contained shall restrict prospecting, locating, developing, mining, entering, leasing, or patenting the mineral resources of the lands under the applicable laws: Provided further, that any lands within the described area which are otherwise withdrawn or reserved will be affected hereby only insofar as may be consistent with the uses and purposes for which such prior withdrawal or reservation was made: And provided further, That upon the termination of any private right to, or appropriation of, any public lands within the exterior limits of the area included in this order, or upon the revocation of prior withdrawals unless expressly otherwise provided in the order of revocation, the lands involved shall become part of this preserve:

\section{(Legal Description available in FWS office Lewistown, Montana.)}

This range or preserve, insofar as it relates to conservation and development of wildlife, shall be under the joint jurisdiction of the Secretaries of the Interior and Agriculture, and they shall have power jointly to make such rules and regulations for its protection, administration, regulation, and improvement, and for the removal and disposition of surplus game animals, as they may deem necessary to accomplish its purposes, and the range or preserve, being within grazing districts duly established pursuant to the provisions of the act of June 28, 1934, ch. 865, 48 Stat. 1269, as amended by the act of June 26, 1936, Public No. 827 , 74th Congress, shall be under the exclusive jurisdiction of the Secretary of the Interior, so far as it relates to the public grazing lands and natural forage resources thereof: Provided, however, That the natural forage resources therein shall be first utilized for the purpose of sustaining in a healthy condition a maximum of four hundred thousand $(400,000)$ sharp-tailed grouse, and one thousand five hundred $(1,500)$ antelope, the primary species, and such nonpredatory secondary species in such numbers as may be necessary to maintain a balanced wildlife population, but in no case shall the consumption of forage by the combined population of the wildlife species be allowed to increase the burden of the range dedicated to the primary species: Provided further, That all the forage resources within this range or preserve shall be available, except as herein otherwise provided with respect to wildife, for domestic livestock under rules and regulations promulgated by the 
Appendix 4. (Cont'd.)

Secretary of the Interior under the authority of the aforesaid act of June 28, 1934, as amended: And provided further that Land within the exterior limits of the area herein described, acquired and to be acquired by the United States for the use of the Department of Agriculture for conservation of migratory birds and other wildlife, shall be and remain under the exclusive administration of the Secretary of Agriculture and may be utilized for public grazing purposes only to such extent as may be determined by the Said Secretary to be compatible with the utilization of said lands for the purposes for which they were acquired as aforesaid under regulations prescribed by him.

The reservation made by this order supersedes as to the abovedescribed lands the temporary withdrawal for classification and other purposes made by Executive Order No. 6910 of November 26, 1934, as amended.

This preserve shall be known as the Fort Peck Game Range.

Franklin D. Roosevelt

The White House,

December 11, 1936.

(No. 7509)

(F.R. Doc. 3825-Filed, December 14, 1936; 2:30 p.m.) 


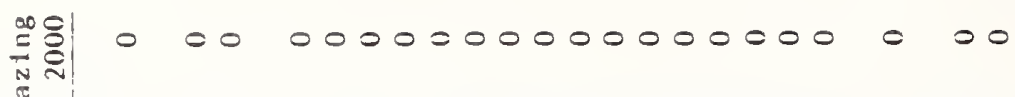

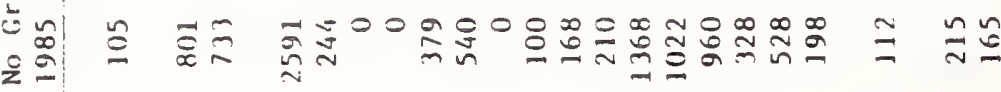

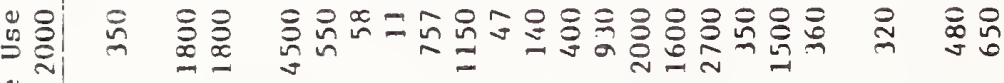

$\div$

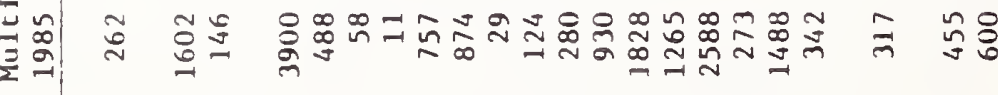

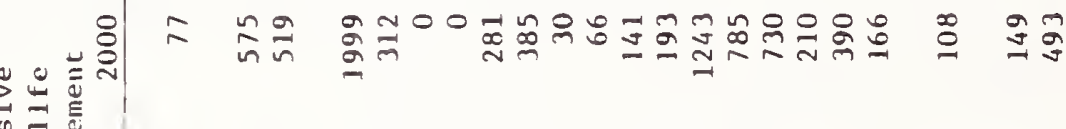

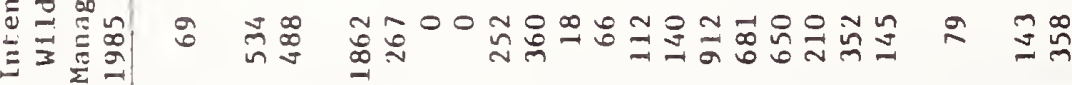

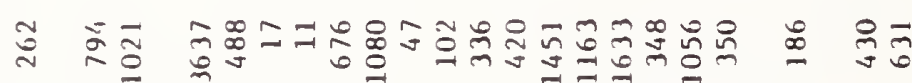

$\bar{\square}$

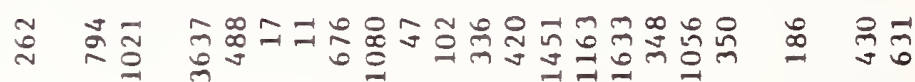<smiles>CC(C)(C)C</smiles>

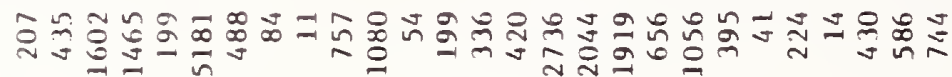

¿a

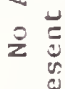

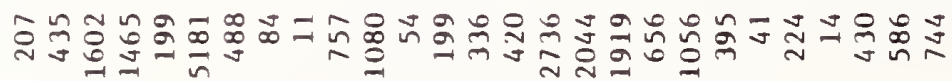

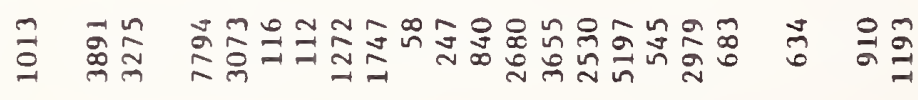


00000000000000000000000000

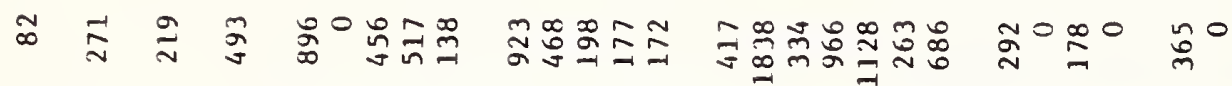

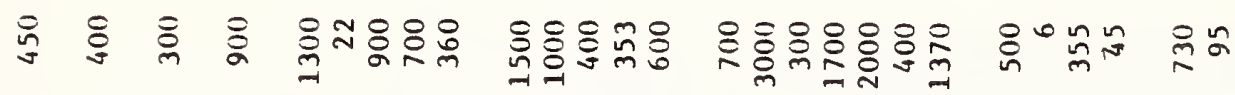

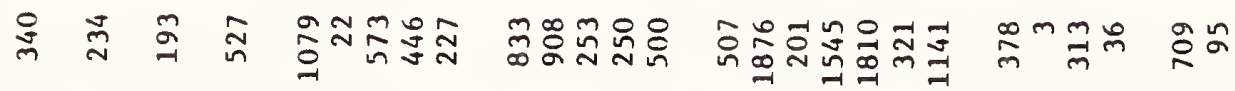

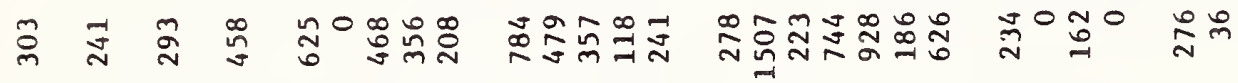

N

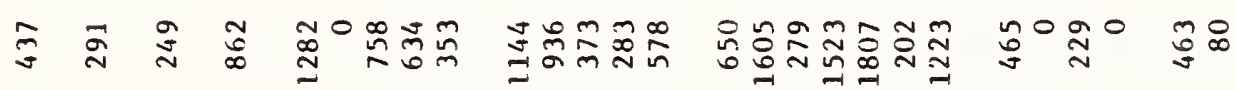

$$
\text { 落 }
$$

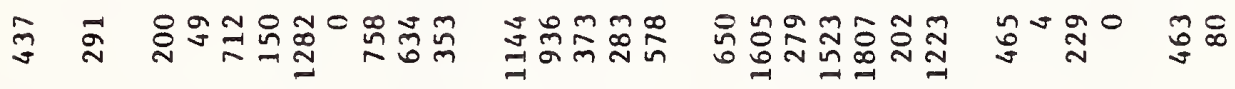

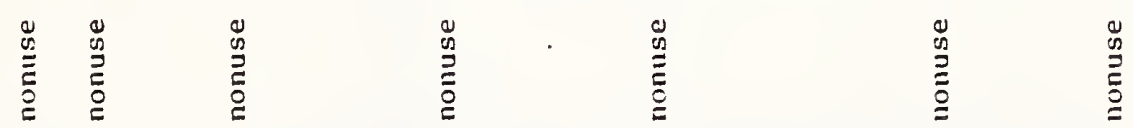

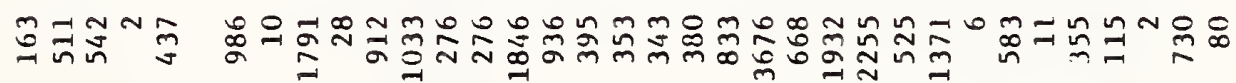

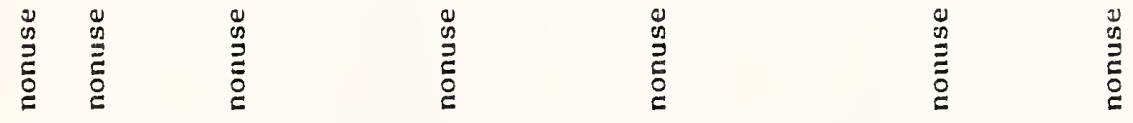

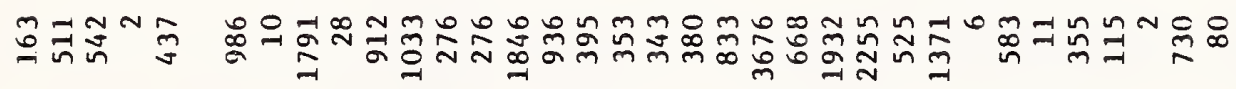

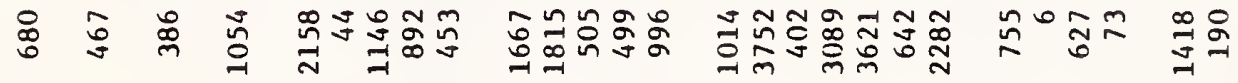

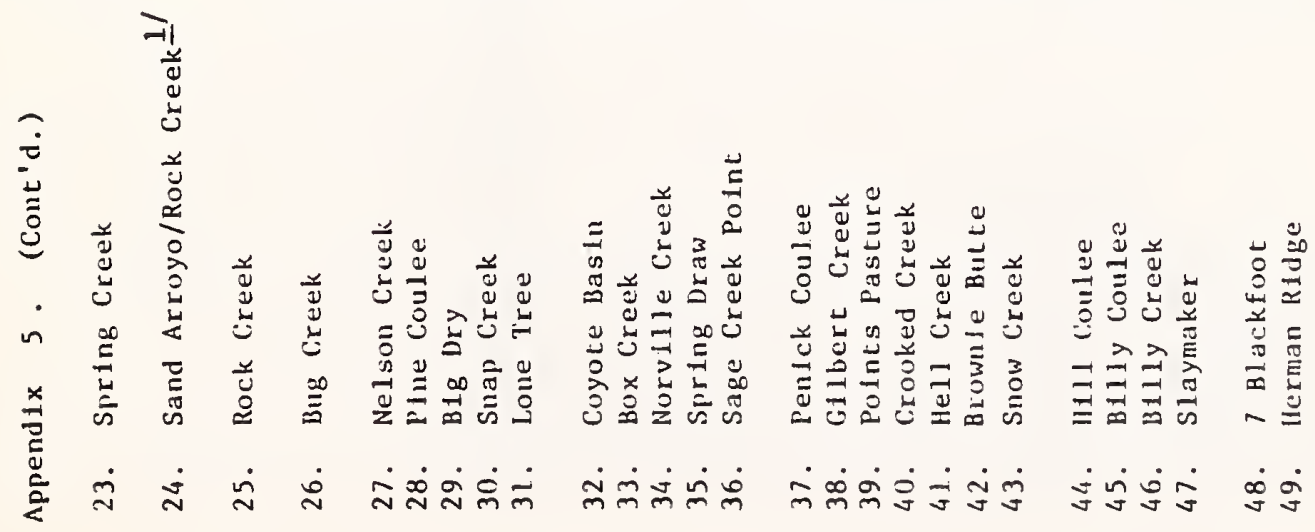


000000000000000000000

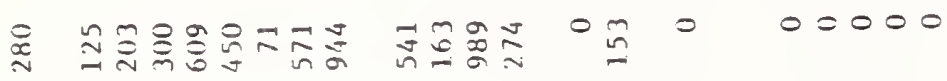

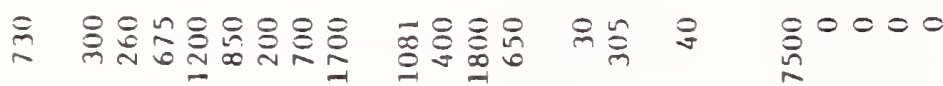

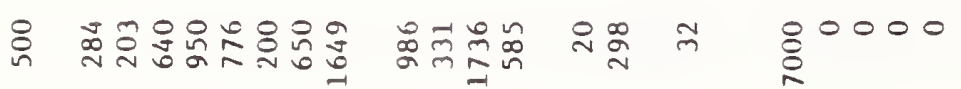

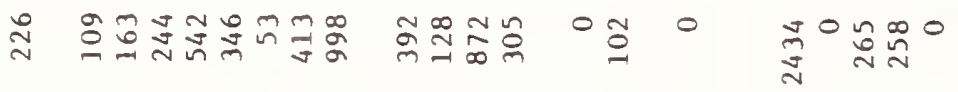

商

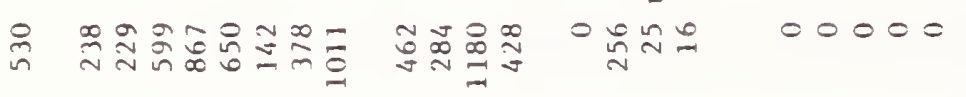

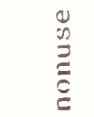

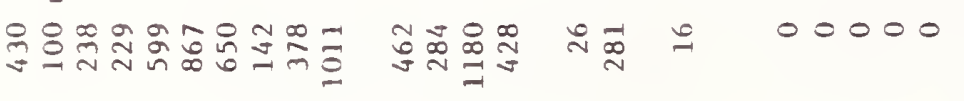

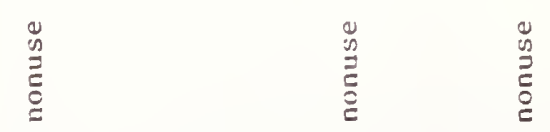

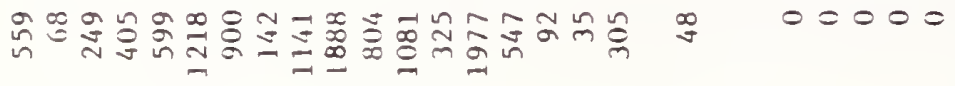

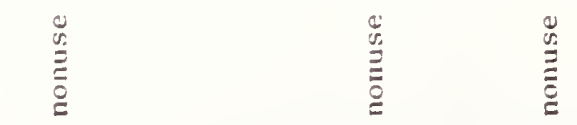

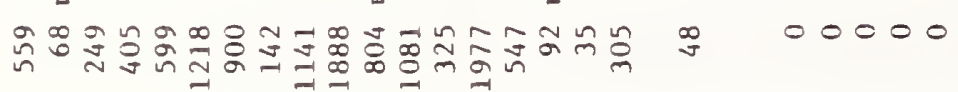

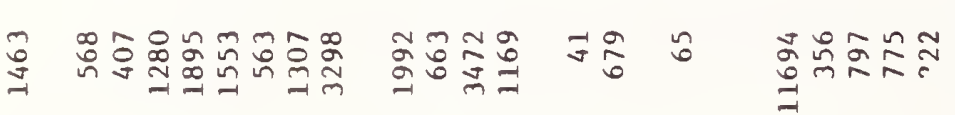

0
-1

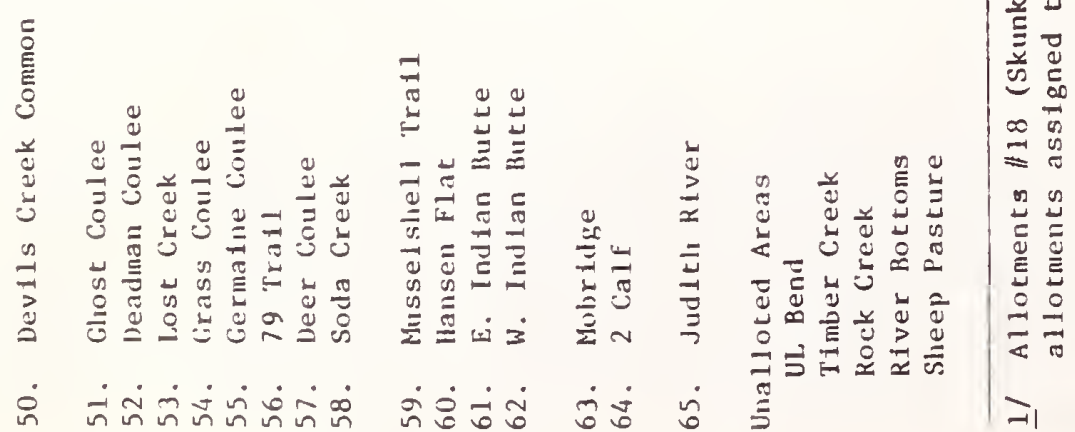


Appendix 6. Public Law 94-223 94th Congress, H.R. 5512, February 27, 1976.

To amend the National Wildlife Refuge System Administration Act of 1966, and for other purposes.

Be it enacted by the Senate and House of Representatives of the United States of America in Congress assembled, That subsection (a) of section 4 of the National Wildlife Refuge System Administration Act of 1966 (16

U.S.C. 668dd (a) is amended to read as follows:

"(a)(1) For the purpose of consolidating the authorities relating to the various categories of areas that are administered by the Secretary of the Interior for the conservation of fish and wildlife, including species that are threatened with extinction, all lands, waters, and interests therein administered by the Secretary as wildlife refuges, areas for the protection and conservation of fish and wildlife that are threatened with extinction, wildlife ranges, game ranges, wildlife management areas, or waterfowl production areas are hereby designated as the 'National Wildlife Refuge System' (referred to herein as the 'System'), which shall be subject to the provisions of this section, and shall be administered by the Secretary through the United States Fish and Wildlife Service. With respect to refuge lands in the State of Alaska, those programs relating to the management of resources for which any other agency of the Federal Government exercises administrative responsibility through cooperative agreement shall remain in effect, subject to the direct supervision of the United States Fish and Wildlife Service, as long as such agency agrees to exercise such responsibility.

"(2) No acquired lands which are or become a part of the System may be transferred or otherwise disposed of under any provision of law (except by exchange pursuant to subsection (b) (3) of this section) unless--

"(A) the Secretary of the Interior determines with the approval of the Migratory Bird Conservation Commission that such lands are no longer needed for the purposes for which the System was established; and

"(B) such lands are transferred or otherwise disposed of for an amount not less than--

"(i) the acquisition costs of such lands, in the case of lands of the System which were purchased by the United States with funds from the migratory bird conservation fund, or fair market value, whichever is greater; or

"(ii) the fair market value of such lands (as determined by the Secretary as of the date of the transfer or disposal), in the case of lands of the System which were donated to the System.
Nationa1 Wildlife

Refuge System Administration Act of 1966, amendments.

"Nationa1 Wildlife Refuge System."

Transfer or disposal of lands, restriction. 
Appendix 6. (Cont'd.)

Pub. Law 94-223

February 27, 1976

The Secretary shall pay into the migratory bird conservation fund the aggregate amount of the proceeds of any transfer or disposal referred to in the preceding sentence.

"(3) Each area which is included within the System on January 1, 1975, or thereafter, and which was or is--

"(A) designated as an area within such System by law, Executive order, or secretarial order; or

"(B) so included by public land withdrawal, donation, purchase, exchange, or pursuant to a cooperative agreement with any State or local government, any Federal department or agency, or any other governmental entity, shall continue to be a part of the System until otherwise specified by Act of Congress, except that nothing in this paragraph shall be construed as precluding--

"(i) the transfer or disposal of acquired lands within any such area pursuant to paragraph (2) of this subsection;

"(ii) the exchange of lands within any such area pursuant to subsection (b)(3) of this section; or

"(iii) the disposal of any lands within any such area pursuant to the terms of any cooperative agreement referred to in subparagraph (B) of this paragraph."

Approved February 27, 1976.

\section{LEGISLATIVE HISTORY:}

HOUSE REPORT No. 94-334 (Comm. on Merchant Marine and Fisheries). SENATE REPORT No. 94-593 (Comm. on Commerce).

CONGRESSIONAL RECORD:

Vo1. 121 (1975): Nov. 14, considered and passed House.

Vol. 122 (1976): Feb. 4, considered and passed Senate, amended.

Feb. 17, House concurred in Senate amendment. 
Appendix 7. Soils limitations and capability classes,

Charles M. Russell National Wildlife Refuge, Montana.

Soil limitations

The following soil mapping units on the refuge should not be grazed (W. Larsen personal communication):

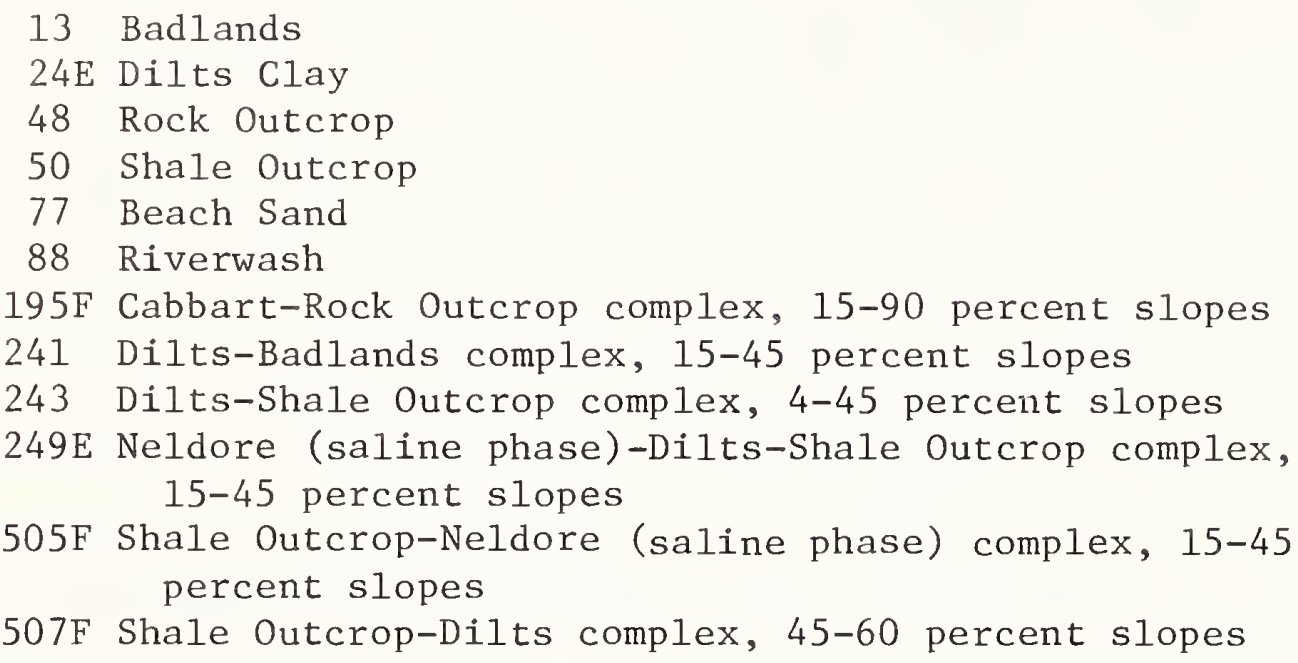

In addition, those mapping unit complexes having badlands, rock outcrop or shale outcrop included were recognized as having limitations in that no forage allocations should be allotted to the badlands, rock outcrop or shale portions (Appendix Table 7-A). It was recognized that those complexes containing rock outcrop or shale outcrop could provide limited grazing on the remainder of the mapping unit. No AUMs for wildlife or livestock were calculated for the following: rock outcrop, shale outcrop, beach sand, riverwash and portions of those complexes containing one of the above as a component. A shortened time frame for completion of the EIS did not allow for examination and elimination of all mapping units listed in Appendix Table 7-A. Most notable of the omitted mapping units are others including the Dilts series, a commonly represented soil complex component on the refuge.

The problem of soils limitations for grazing was analyzed and resolved in the following manner: it was recognized that certain soils should support no livestock grazing; however, it would be impractical and costly to fence these individual areas to prevent livestock use. Exclusion of an entire area from use because of soils limitations on only a portion of the area is not feasible. A practical way to solve the problem would be to recognize that soils limitations do exist, that it is nearly impossible to deny livestock use or wildlife use but that overall stocking rates should be adjusted accordingly.

Soil capability classes

Capability grouping shows, in a general way, suitability of soils 


\section{Appendix 7. (Cont'd.)}

for most land uses. Groups are made according to limitations of the soils when used for field crops, risk of damage when they are used and the way they respond to treatment. The grouping does not take into account major and generally expensive land forming that would change slope, depth or other characteristics of the soils nor possible but unlikely major reclamation projects and does not apply to rice, cranberries, horticultural crops or other crops requiring special management.

Those familiar with the capability classification can infer from it much about the behavior of soils when used for other purposes but this classification is not a substitute for interpretations designed to show suitability and limitations of groups of soils for range, forest trees or engineering.

In the capability system, all soils are grouped at three levels: capability class, subclass and unit. In this report, only the first two levels are given for each mapping unit, since soils on CMR are not generally used for crops.

Capability classes, the broadest groups, are designated by Roman numerals I through VIII. The numerals indicate progressively greater limitations and narrower choices for practical use, defined as follows:

Class I-few limitations restricting use.

Class II-moderate limitations that reduce choice of plants or that require moderate conservation practices.

Class III-severe limitations that reduce choice of plants, require special conservation practices or both.

Class IV-very severe limitations that reduce choice of plants, require very careful management or both.

Class V-not likely to erode but have other limitations, impractical to remove, that limit use largely to pasture, range, woodland or wildife.

Class VI-severe limitations that make them generally unsuited to cultivation and limit use largely to pasture, range, woodland or wildife.

Class VII-very severe limitations that make them unsuited to cultivation and that restrict use largely to pasture, range, woodland or wildlife.

Class VIII-limitations that preclude use for commercial plants and restrict use to recreation, wildlife, water supply or esthetic purposes.

Capability subclasses are soil groups within one class; they are designated by adding a small letter, $\underline{e}, \underline{w}, \underline{s}$, or $\underline{c}$ to the class numeral, for example, Ile. The letter e shows that the main limitation is risk of erosion unless close-growing plant cover is maintained, w shows that water in or on the soil interferes with plant growth or cultivation (in 


\section{Appendix 7. (Cont'd.)}

some soils the wetness can be partly corrected by artificial drainage), $\underline{s}$ shows that the soil is limited mainly because it is shallow, salty, droughty or stony and $c$, used in only some parts of the United States, shows that the chief limitation is climate that is too cold or dry.

In Class I there are no subclasses because soils of this class have few limitations. Class $V$ can contain, at most, only subclasses indicated by $\underline{w}, \underline{s}$ and $\underline{c}$ because soils in Class $V$ are subject to little or no erosion, though they have other limitations that restrict use largely to pasture, range, woodland, wildlife or recreation. 


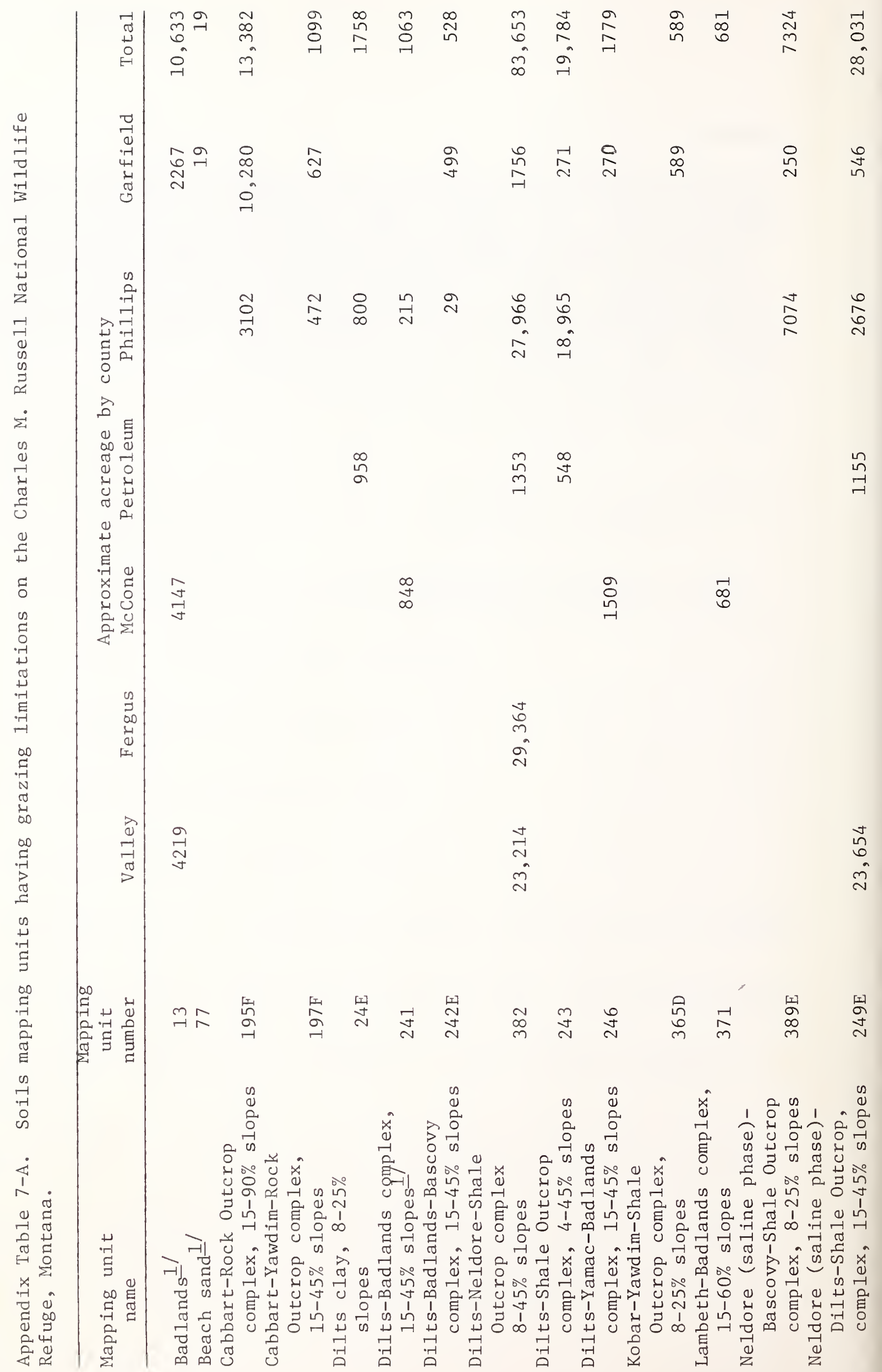




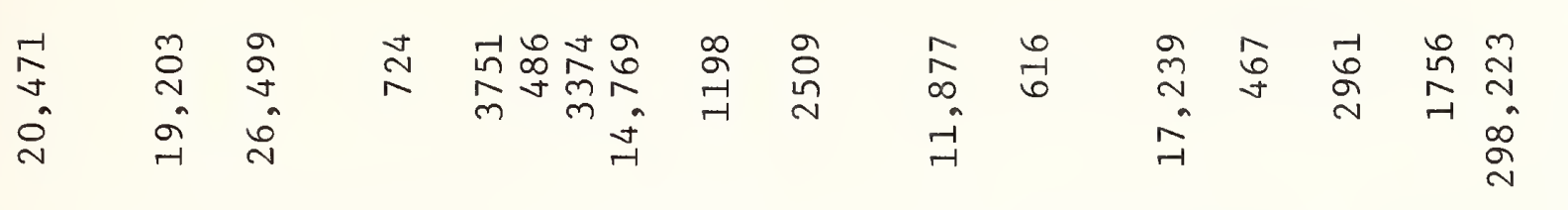

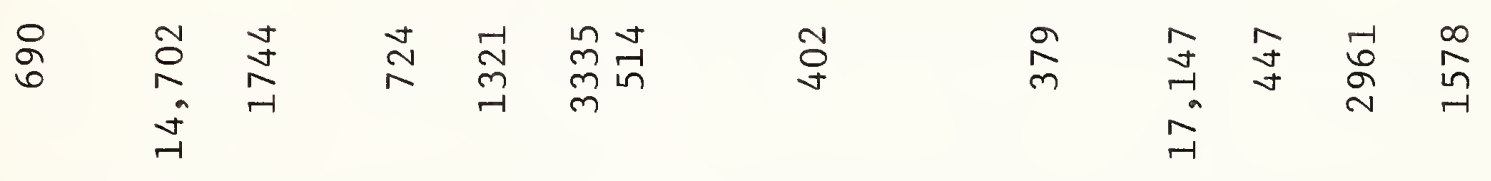

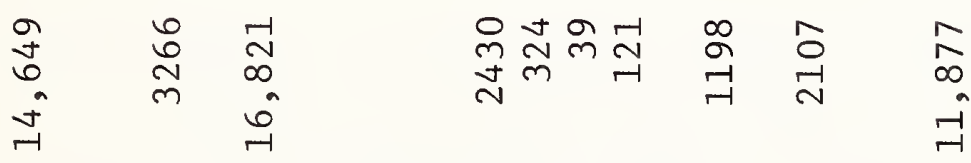

i

๙

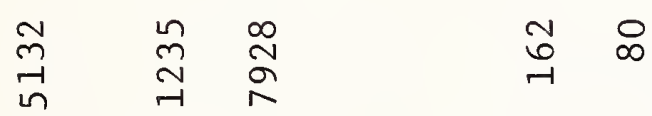

$\infty$

ñ

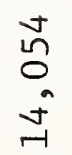

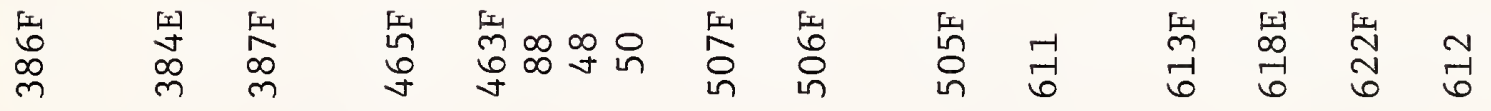

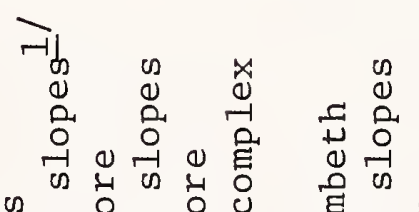

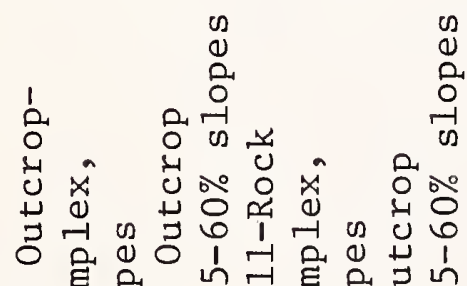

$n$
0
0
0
0
01
01

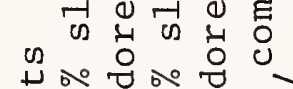

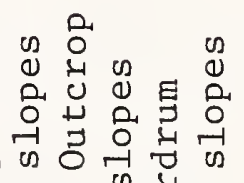

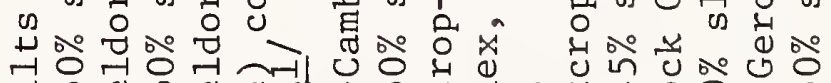

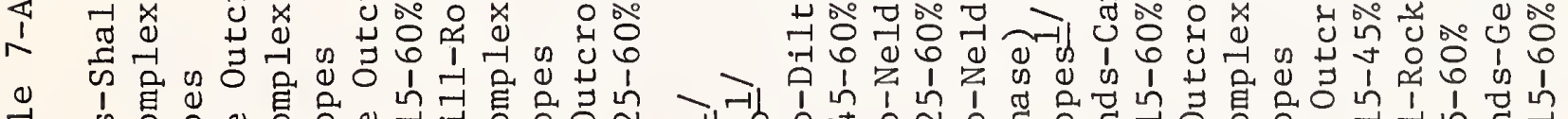

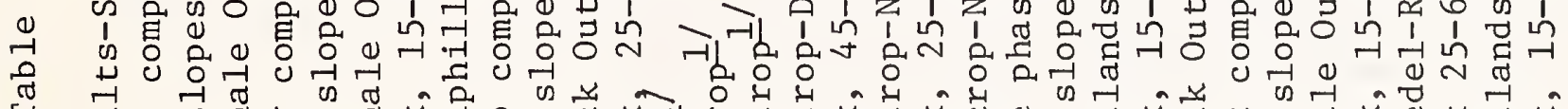

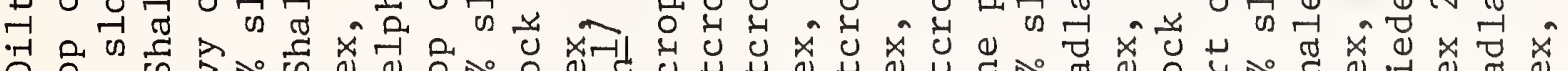

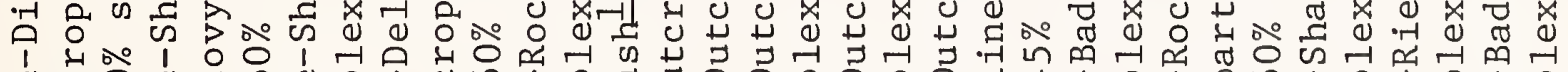

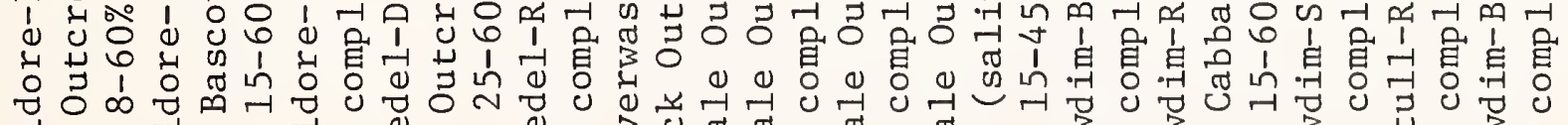
至 
Appendix 8. Range survey methodology and productivity, Charles M. Russell National Wildlife Refuge, Montana.

\section{Methodology}

A range site and condition survey was conducted on CMR in 1978 by four SCS range specialists. The survey was in accordance with the 1976 SCS National Range Handbook.

Soils mapping was done prior to the range survey in accordance with standard soil survey procedures. Mapping procedures consisted of identifying known soil series or complexes and mapping these units on 1:24000 aerial photographs. Once the soils mapping was completed for a given area, range/soils specialists devised a correlation key for mapping range sites on the basis of soils units. Range site mapping units are based upon soils mapping units but are expressed in terms of general soils features, instead of series names and slope gradients used in standard soil survey procedures. For example, a soil identified as an Absher clay loam, 0-4 percent slopes in the soil survey would be considered a dense clay range site for purposes of range survey procedures. This key, which contains all range site/soils mapping units present on the refuge, is on file in the refuge headquarters in Lewistown.

Range sites and condition classes for all lands within the refuge above the high water mark of Fort Peck Reservoir, 2250 feet msl, were mapped on 1:24000 scale aerial photographs. The range sites were then tallied by site and condition class acreages for all sections within the refuge by FWS. These range site summaries are also on file in Lewistown. Following the acreage tabulations, each section was assigned to a precipitation zone and geographic location and initial stocking rates were tabulated in terms of total AUMs/section in accordance with the SCS Montana Grazing Guides. This stocking rate is based upon the amount of forage that can be taken during normal or average years and still maintain or improve the range condition. Recommended stocking rates are obtained by examining the soil's properties, which are fundamental to this inventory system and the basis for naming a given range site and upon geographic and topographic features and climate (precipitation). The recommended stocking rates assume that reasonably uniform grazing will occur over the entire area. Stocking rate cuts for inaccessibility because of topography or lack of water are not provided in the SCS Montana Grazing Guides and are left to the planner's or manager's knowledge of the area for final stocking rate appropriations (Appendix 15).

Clipping studies on pristine sites resulted in information which lends insight to the productivity of these sites at climax and the percent weight composition by species in the climax community. Normally, productivity of different sites is expressed in terms of annual production by air dry weight in favorable years, unfavorable years and long-term average for sites rated as excellent condition. Comparison of the present range situation expressed as a percentage of the potential at climax provides the observer with an ecological site condition rating. Appendix Table 8-A summarizes expected annual site productivity for range sites commonly found on the wildlife refuge. Data presented are 
Appendix 8. (Cont'd.)

taken from SCS range guides and technical guides and are presented only as general figures for those sites. The information does provide insight as to how soils limitations such as depth, texture and salinity problems affect vegetative productivity. Additional information regarding site productivity has been collected by Prodgers in response to differences in precipitation (Appendix Table 8-B).

Criticisms concerning this survey were particularly directed toward the fact that 1978 was an abnormally high moisture year. Vegetative production was much greater than normal on the refuge. Critics of the survey indicated that perhaps this biased the range condition upward and provided a distortion that range conditions were better than the actual situation.

It should be stated that range condition determined by SCS methods is based upon percent by weight of the current year's growth (actual air-dry measurements or estimates) of each species in the community and the percent that should be present in a climax situation. The high moisture year of 1978 would have provided as realistic a situation as one of drought; annual weeds would normally not grow at all during an exceptionally dry year, whereas they would be abundant in wet years. Perennial grasses, forbs and shrubs would be less affected because of better adapted root systems. Rates of vegetative production in perennial species would be less likely to show the extreme fluctuations shown by annuals during years of high or low rainfall.

Through the summer, periodic clipping evaluations were made to verify range survey results. No major discrepancies were found.

Range Sites and Range Condition

There are many differences in soils and climate of the survey area. For these reasons there are several different kinds of rangeland. These different kinds of rangeland are called range sites. The best adapted group of plants is called the potential or climax community for the site. The climax plant community for a site varies slightly from year to year but the kinds and percentage of plant composition remain about the same if undisturbed. Each range site has the ability to produce a different kind and/or amount of climax vegetation than any other range site.

The original or climax combination of plants fitted the soil and climate of the site so perfectly that other kinds of plants could not move in unless the area was disturbed. So consistent is the relationship between plants, climate and soil that the climax plant community can be predicted even on severely disturbed sites if the soil is identified.

Range conservationists and soil scientists, working together, group soils which naturally grow the same climax plant communities into range sites. 
Appendix 8. (Cont'd.)

Repeated overuse by grazing animals, excessive burning or plowing result in changes in the kinds, proportions or amounts of climax plants in the plant community. Depending on the kind and degree of disturbance, some kinds of plants increase while others decrease. If disturbance is severe, plants which do not belong in the climax plant community may invade. Plant response to grazing use depends on the kind of grazing animal, season of use and how closely the plant is grazed. Under good management near-climax plant communities can be maintained or, in the case of disturbed vegetation, the climax plant community will be gradually re-established unless the soils have been seriously eroded.

Plants are categorized into decreasers, increasers or invaders according to their response to grazing pressures.

Decreasers are climax dominant plants that tend to decrease in relative amounts under close grazing. They are generally the most productive and most palatable to grazing animals.

Increasers are plants in the climax vegetation that increase in relative amounts as the more desirable decreaser plants are reduced by close grazing. They are generally less palatable, woody, spiny or so short they escape close grazing.

Invaders are weedy type plants or exotics that cannot stand the competition of climax vegetation. They fill the void if the climax plants are diminished or eliminated by disturbance.

Range condition is an expression of the present kind of vegetation in relation to the climax plant community for that site. The more nearly the present kinds and amounts of plants are like the climax plant community, the higher the range condition.

A range is in excellent condition if 76-100 percent of the vegetation is of the same kinds as the climax stand. It is in good condition if the percentage is 51-75. It is in fair condition if the percentage is 26-50 and in poor condition if the percentage is less than 25 .

The present range condition provides an index to changes which have taken place in the plant community. More importantly, however, range condition is a basis for predicting the kinds and amounts of changes in the present plant community which can be expected from management and treatment measures.

Thus, the range condition rating indicates the nature of the present plant community and the climax plant cover for the range site represents a goal toward which rangeland management may be directed.

Knowledge of climax plant communities of range sites and the nature of present plant communities in relation to that potential is important in planning and applying conservation on rangeland. Such information is the basis for selecting management objectives, design of grazing systems, managing for wildlife, determining potential for recreation and for rating watershed conditions.

Any management objective on rangeland must provide for a plant cover which will adequately protect or improve the soil and water resources and meet the needs of the operator. This usually involves 
Appendix 8. (Cont'd.)

increasing desirable plants and restoring the plant community to near climax conditions. Sometimes, however, a plant cover somewhat below climax will better fit specific grazing needs or wildlife habitat while still protecting soil and water resources.

Al1 range sites respond favorably to proper grazing use and systems of grazing deferments.

\section{LEGEND FOR RANGE SITES}

Range sites are kinds of rangeland that differ from each other in their ability to produce a significantly different kind or amount of climax or original vegetation. Only natural grasslands are classified as range sites. To fully designate a range site, a soil-group name is combined with the precipitation ( $\mathrm{pz}$ ) zone and geographic location; e.g. sandy 10-14" pz; glaciated plains, Montana.

The following range soil-groups are listed in presumed order of natural productivity, considering total airdry weight of all herbage produced through the entire year by all seed plants/unit of area, in ordinary years under climax plant cover.

Range site descriptions:

I. Soil groups that can produce more herbage than ordinary range upland because of plainly superior soil moisture availability.

WL - wet land: lands where seepage, ponding, etc., raise the water table to above the surface during only a part of the growing season. Too wet for cultivated crops but too dry for common reed, cattails or true aquatics.

Sb - subirrigated: lands with an effective subsurface ground water table and water rarely over the surface during the growing season.

SL - saline lowland: subirrigated and overflow lands where salt and/or alkali accumulations are apparent and salt tolerant plants occur over a major part of the area.

Ov - overflow: areas regularly receiving more than normal soil moisture because of run-in or stream overflow.

II. Soil groups with no obvious soil or moisture limiting factors. The vegetation can make a normal response to climate.

Sa - sands: sands and loamy sands more than 20 inches deep.

Sy - sandy: coarse to fine sandy loams more than 20 inches deep.

Si - silty: soils more than 20 inches deep of very fine sandy loam, loam or silt loam. This includes soils with 2 inches or more of silt loam over clayey subsoils. 
Appendix 8. (Cont'd.)

Cy - clayey: granular clay. loam, silty clay loam, silty clay, sandy clay or clay more than 20 inches deep.

III. Soil groups with characteristics or topographic features that limit moisture-holding capacity or affect infiltration rates.

$\mathrm{TH}$ - thin hilly: loamy or clayey soils on steep or hilly landscapes with a thin A horizon and weak or no structure in the subsoil but with significant root penetration deeper than 20 inches; usually calcareous but contain less than 15 percent calcium carbonate.

St - stony: soils more than 20 inches deep with cobbles or stones occupying 40-80 percent of the surface.

Ly - limy: soils more than 20 inches deep that are nearly white and very limy (15 percent or more calcium carbonate) within 4 inches of the surface.

SwC - shallow clay: shallow granular clay soils that are 10-20 inches deep to underlying shale or nearly impervious clays.

SwG - shallow to gravel: soils that are 10-20 inches deep to sandy gravel. Few roots penetrate deeper than 20 inches.

Sw - shallow: soils 10-20 inches deep to hard rock or softbeds of decomposed granite, siltstone or sandstone; few roots penetrate deeper than 20 inches.

Ps - panspots: areas of silty, clayey or sandy soils in complex with shallow depressions of hard clays or other nearly impervious materials at or near the surface. The shallow depressions occupy 20-50 percent of the site.

DC - dense clay: relatively impervious deep nongranular clays may be overlain by thin ineffectual layers of other materials; the dispersed layer is very hard to extremely hard when dry and very sticky when wet.

TB - thin breaks: mixed soils of various depths with hard rock or other resistant bed outcroppings at different levels on steep irregular slopes; trees may occur locally above outcrops.

Gr - gravel: coarse textured soils with more than 50 percent gravel and cobbles underlain by loose sand and gravel at less than 20 inches. 
Appendix 8. (Cont'd.)

VS -- very shallow: areas where few roots can penetrate deeper than 10 inches. Outcropping of gravel or bedrock is characteristic; joints in bedrock may develop deep soil pockets usually marker by tall grasses, shrubs or stunted trees.

SU - saline upland: soils more than 20 inches deep with salt and/or alkali accumulations; salt tolerant plants occur over a major part of the area.

Sh - shale: readily puddled uplands where some unweathered angular raw shale fragments are exposed at the surface and little, if any, soil profile development is evident.

B1 - badlands: nearly barren lands broken by drainages intermingled with small grazable areas. 
Appendix 8. (Cont'd.)

Appendix Table 8-A. Site productivity of selected range sites on the Charles M. Russell National Wildlife Refuge, Montana. $\underline{\text { G }}$

\begin{tabular}{|c|c|c|c|}
\hline Range site & $\begin{array}{c}\text { High } \\
\text { favorable } \\
\text { years } \\
\text { (1bs./acre) }\end{array}$ & $\begin{array}{c}\text { Low } \\
\text { unfavorable } \\
\text { years } \\
\text { (1bs./acre) }\end{array}$ & $\begin{array}{c}\text { Average } \\
\text { (1bs./acre) }\end{array}$ \\
\hline Overflow & 3000 & 2000 & 2500 \\
\hline Saline lowland & 3500 & 2000 & 3000 \\
\hline Sandy & 2000 & 1000 & 1600 \\
\hline Silty & 1800 & 1000 & 1500 \\
\hline Clayey & 1800 & 900 & 1300 \\
\hline Thin hilly & 1450 & 850 & 1200 \\
\hline Shallow clay & 1200 & 700 & 1000 \\
\hline Shallow to gravel & 1200 & 700 & 1000 \\
\hline Shallow & 1100 & 600 & 900 \\
\hline Panspots & 1200 & 700 & 1000 \\
\hline Dense clay & 1100 & 600 & 900 \\
\hline Thin breaks & 1100 & 600 & 900 \\
\hline Shale & 500 & 300 & 400 \\
\hline Saline upland & 600 & 350 & 500 \\
\hline Badlands & 500 & 300 & 400 \\
\hline
\end{tabular}

1/ 10-14 inches ppt zone. Expected annual production, air dry weight (excellent condition site). 
Appendix 8. (Cont'd.)

Appendix Table 8-B. Comparison of aerial production in 1977 and 1978 on Upper Nelson Creek, approximately 12 miles east of the Charles $\mathrm{M}$. Russel1 National Wildlife Refuge, Montana.1/

\begin{tabular}{|c|c|c|c|}
\hline Community & $\begin{array}{c}1977 \\
\text { production } \\
\text { (1bs./acre) } \\
\end{array}$ & $\begin{array}{c}1978 \\
\text { production } \\
\text { (1bs./acre) } \\
\end{array}$ & $\begin{array}{l}1977: 1978 \\
\text { production }\end{array}$ \\
\hline Little bluestem & 748 & 934 & 1.25 \\
\hline $\begin{array}{l}\text { Silver sagebrush/ } \\
\text { western wheatgrass/ } \\
\text { blue grama }\end{array}$ & 712 & 1801 & 2.53 \\
\hline $\begin{array}{l}\text { Little bluestem- } \\
\text { bluebunch wheatgrass }\end{array}$ & 498 & 1025 & 2.06 \\
\hline $\begin{array}{l}\text { Blue grama threadleaf } \\
\text { sedge/needle-and-thread }\end{array}$ & 361 & 1148 & 3.86 \\
\hline $\begin{array}{l}\text { Bluebunch wheatgrass/ } \\
\text { blue grama-threadleaf }\end{array}$ & 331 & 1143 & 3.45 \\
\hline $\begin{array}{l}\text { Needle-and-thread- } \\
\text { western wheatgrass/ } \\
\text { blue grama }\end{array}$ & 297 & 1264 & 4.25 \\
\hline $\begin{array}{l}\text { Needle-and-thread/blue } \\
\quad \text { grama-threadleaf sedge }\end{array}$ & 194 & 1015 & 5.23 \\
\hline $\begin{array}{l}\text { Western wheatgrass/ } \\
\text { blue grama }\end{array}$ & 180 & 1488 & 8.28 \\
\hline Blue grama & 176 & 692 & 3.93 \\
\hline $\begin{array}{c}\text { Blue grama/western } \\
\text { wheatgrass }\end{array}$ & 14 & 1740 & 122.00 \\
\hline
\end{tabular}

1/ Data from R. Prodgers 1979. 


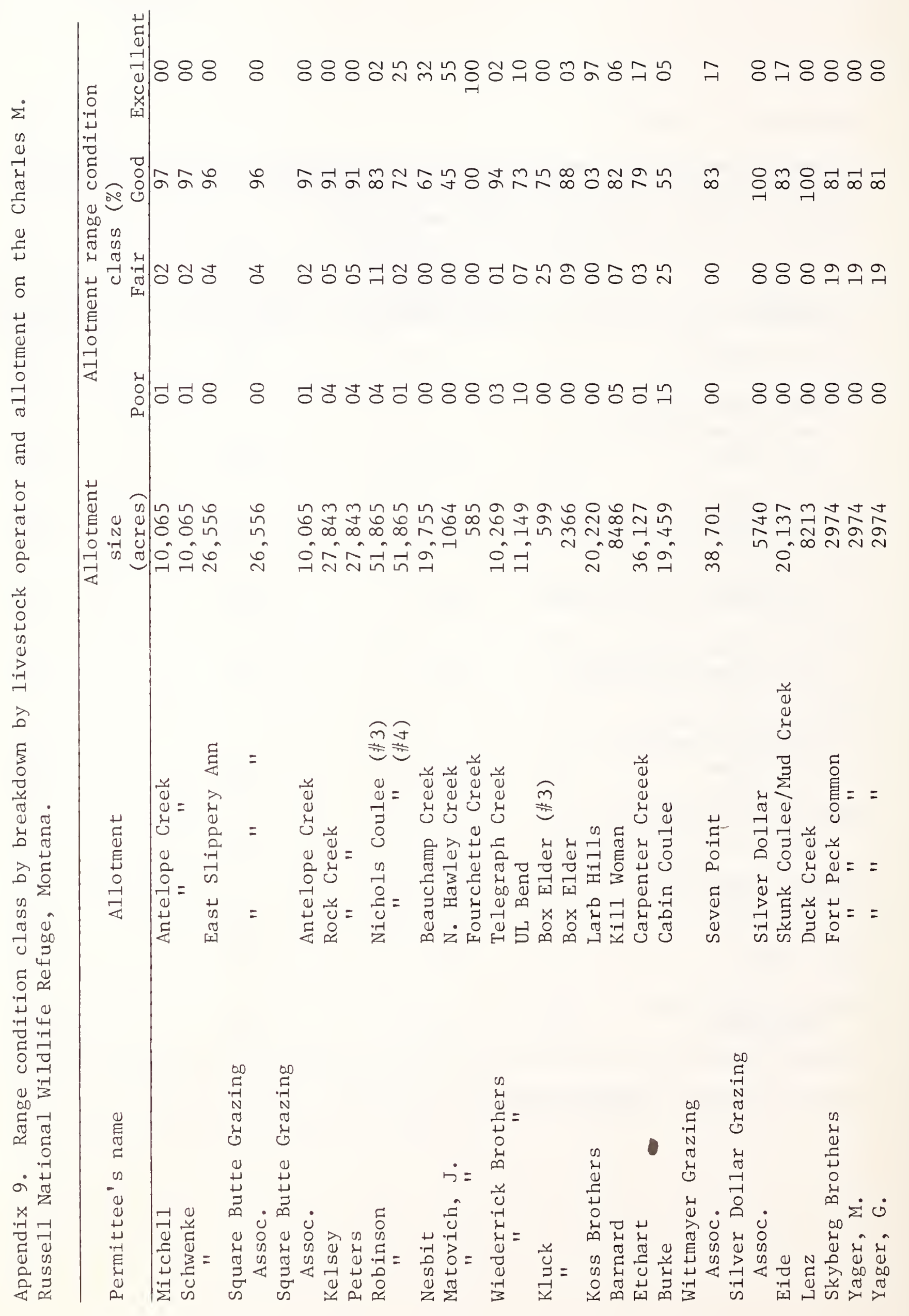




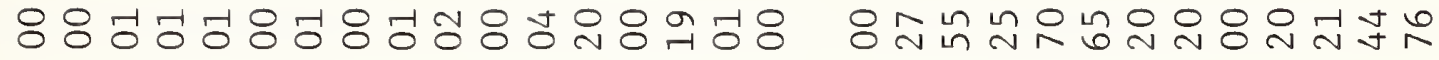

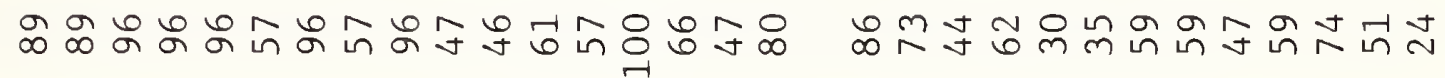

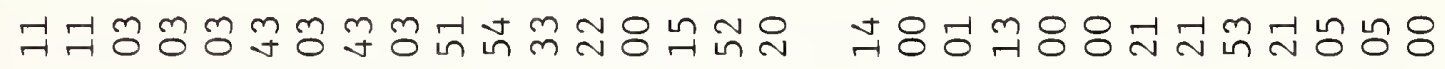
৪৪৪৪৪৪৪৪৪৪৪)

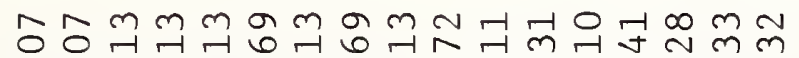

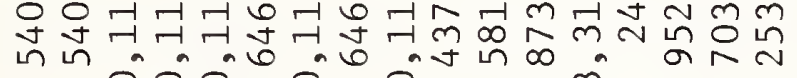

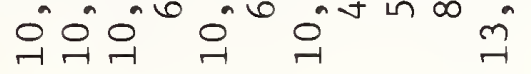

ปِ

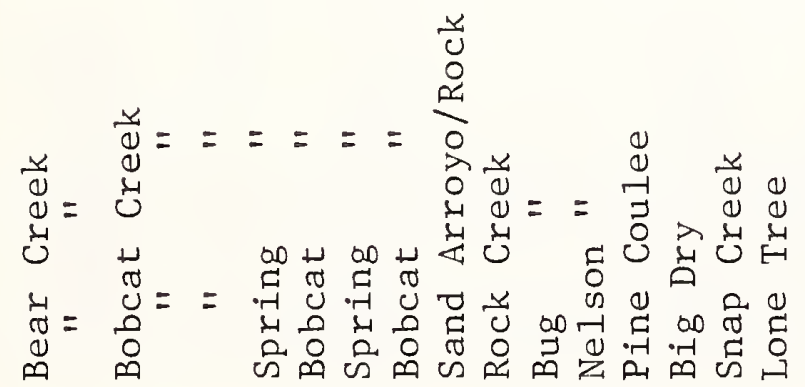

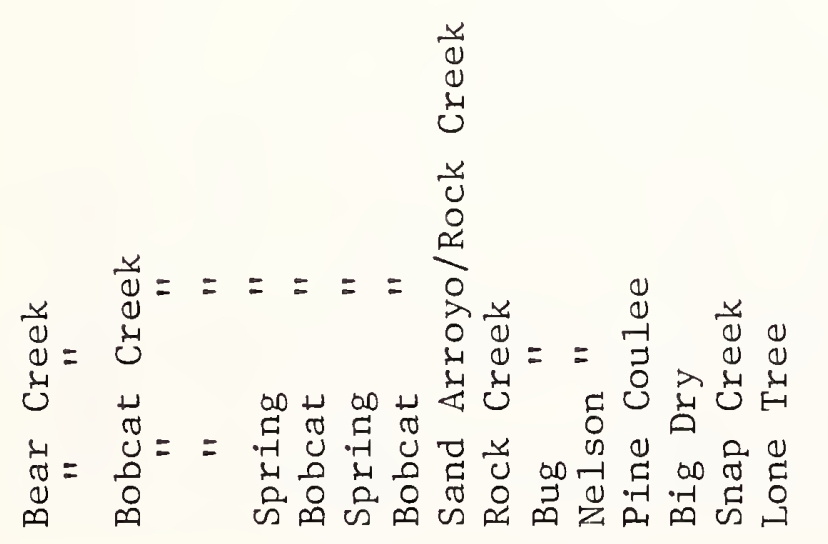

ติ ๆ तैं
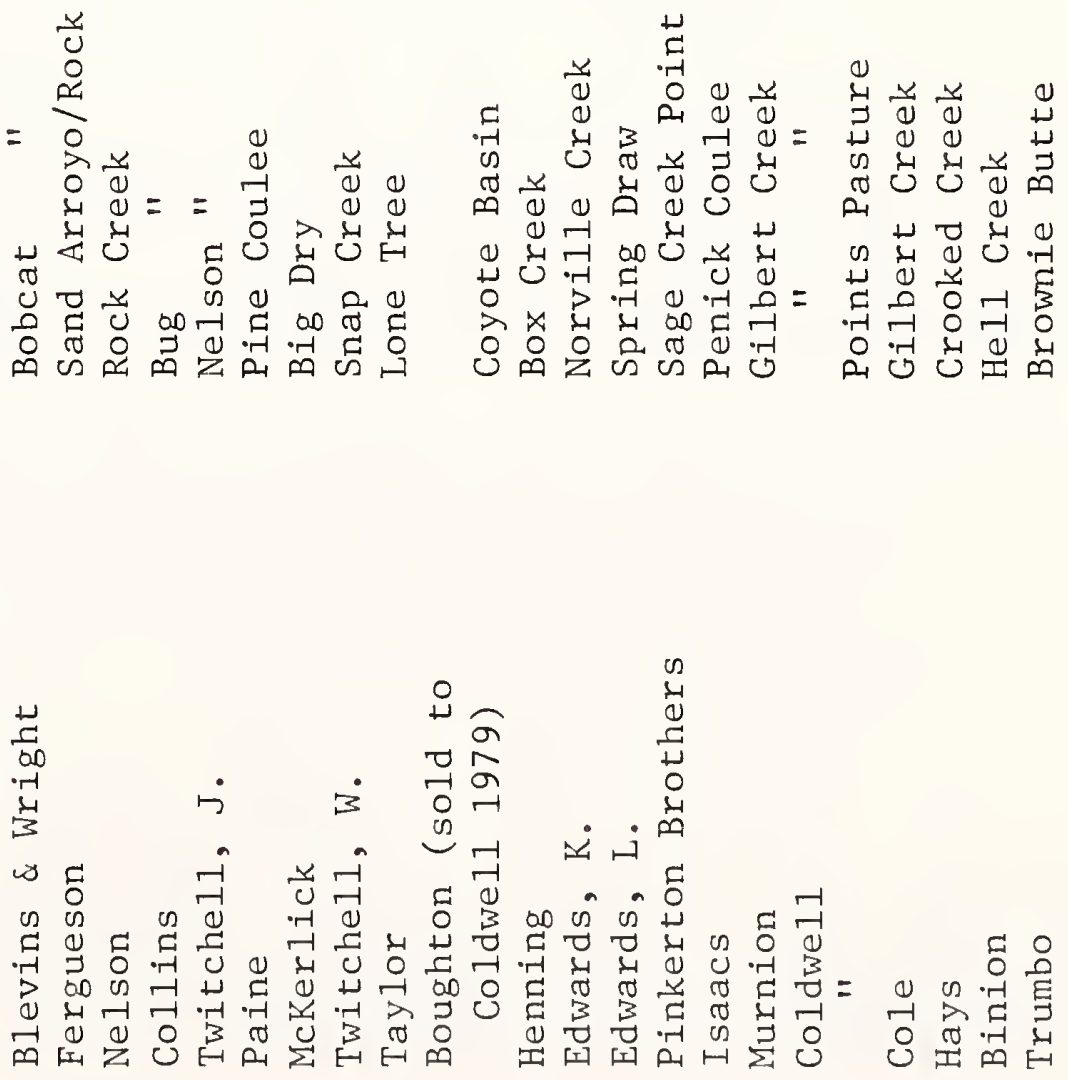


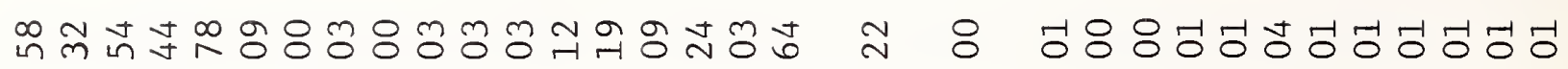

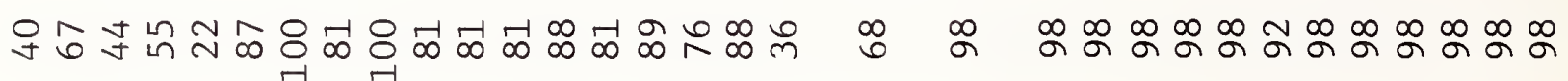

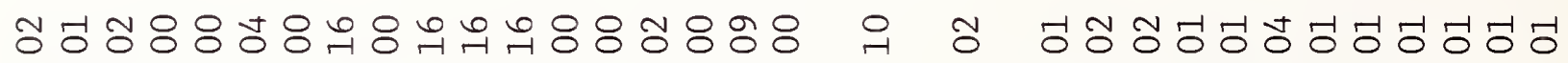

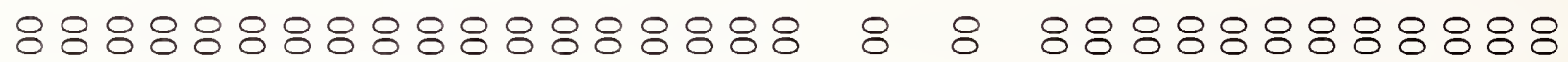

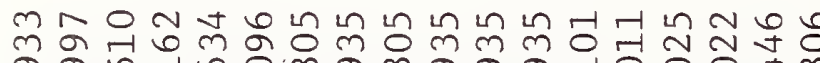

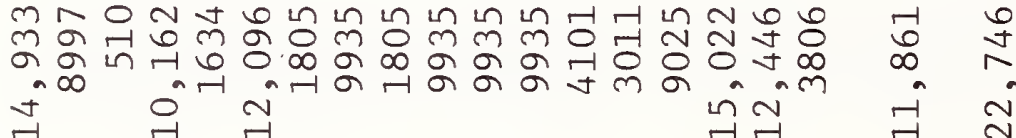

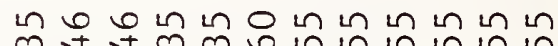

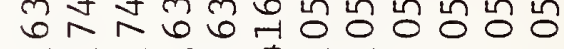

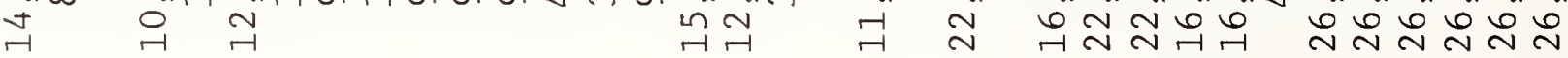
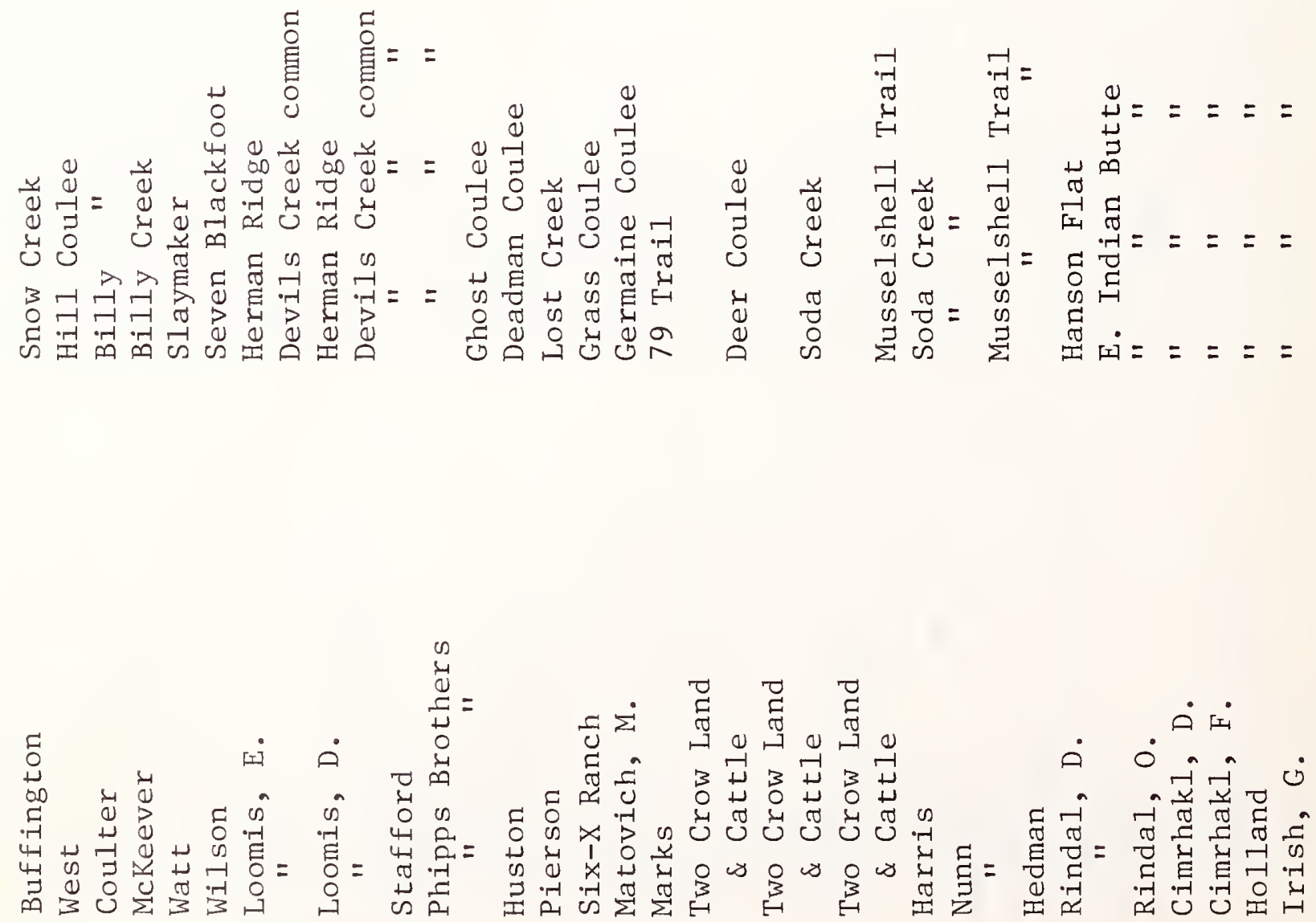


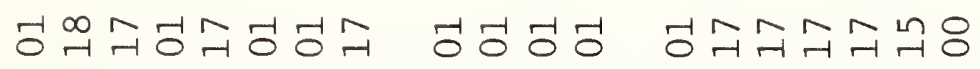

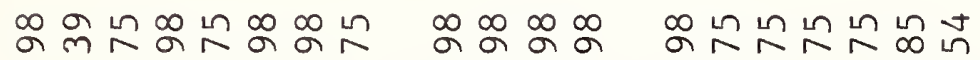

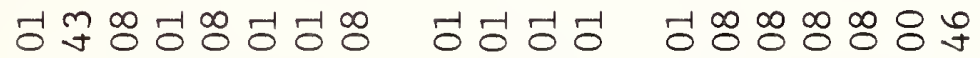

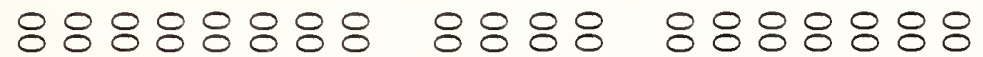

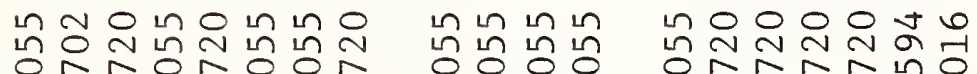
r

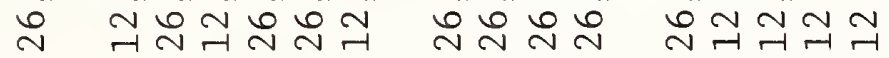

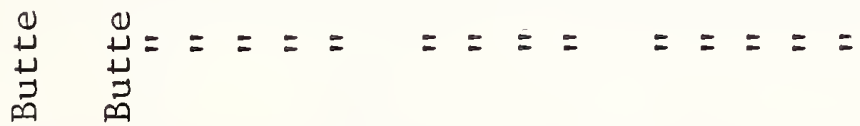

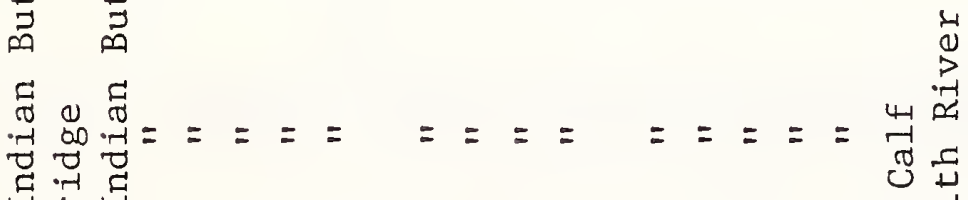

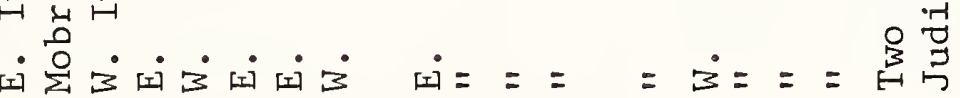

ح̇ं

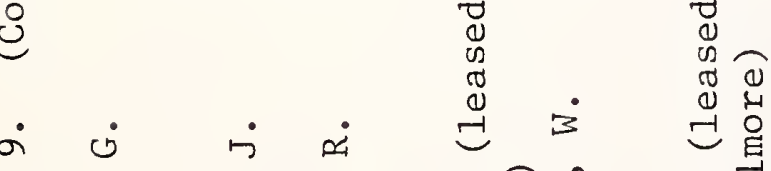

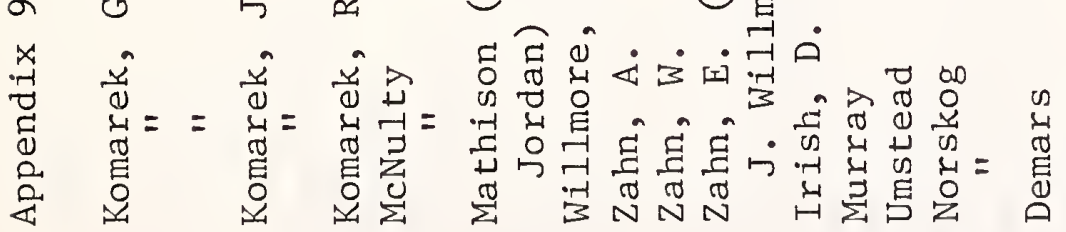




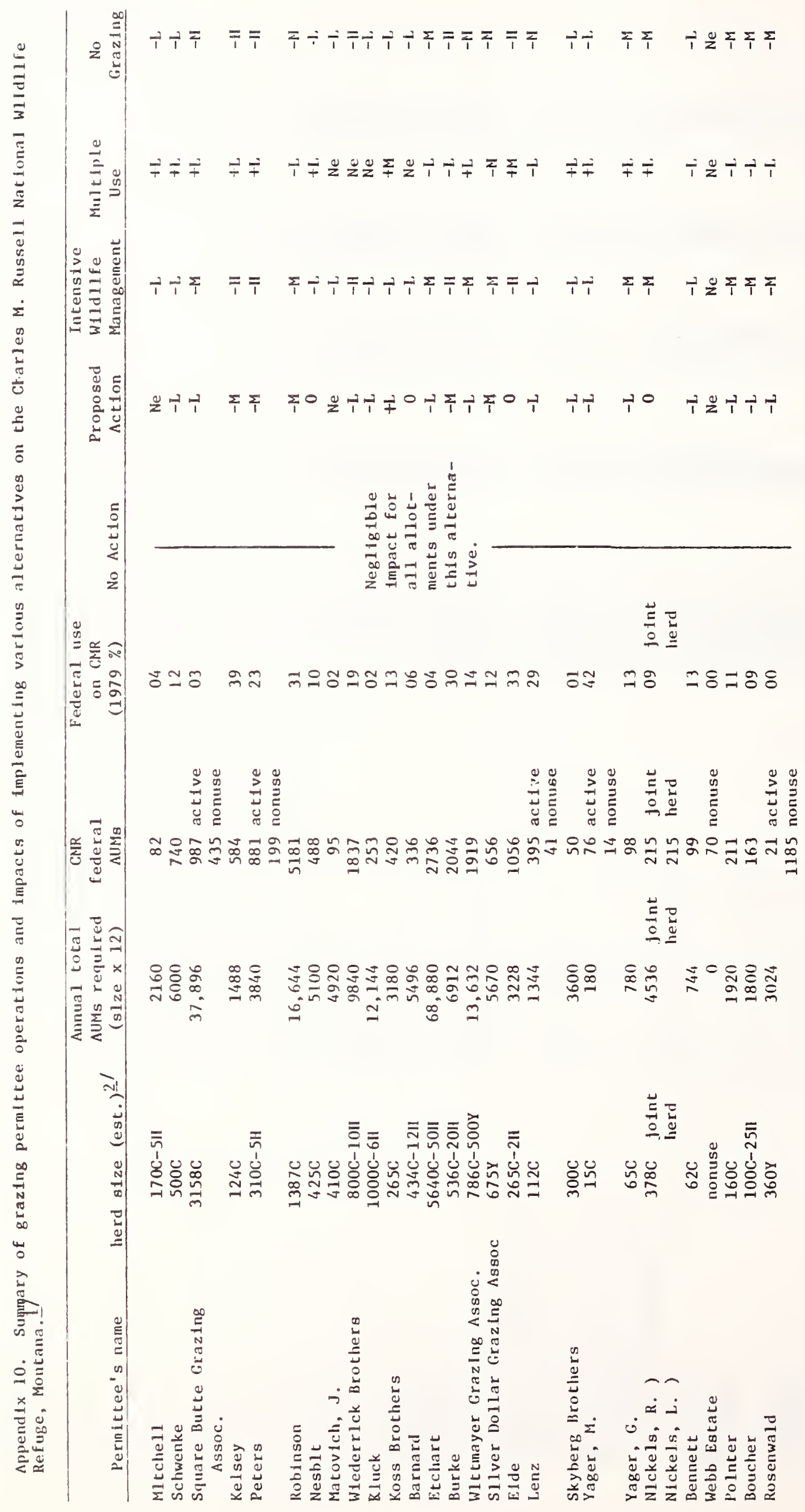




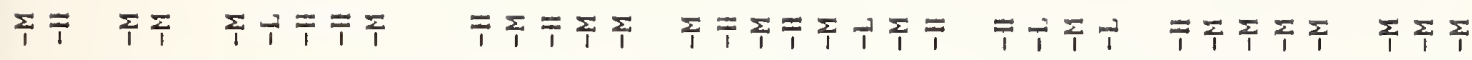

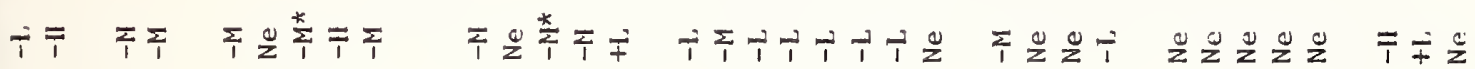

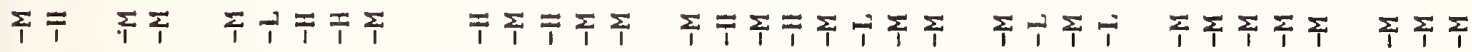

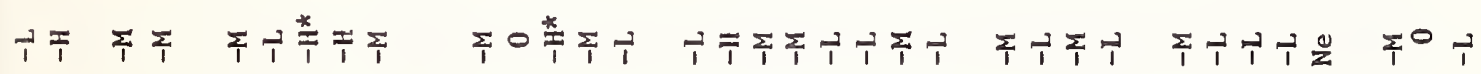

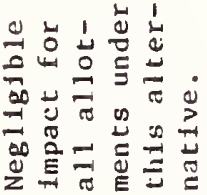

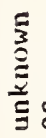

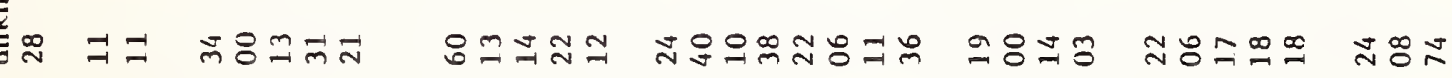

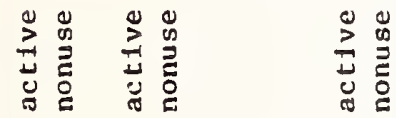

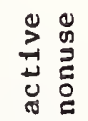

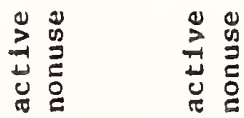

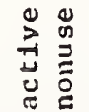

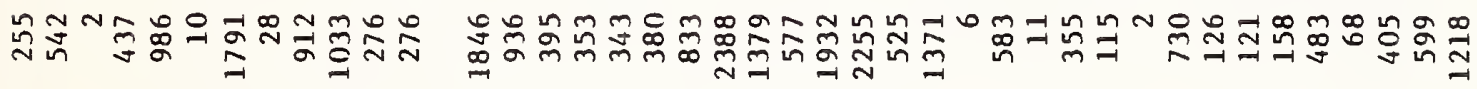

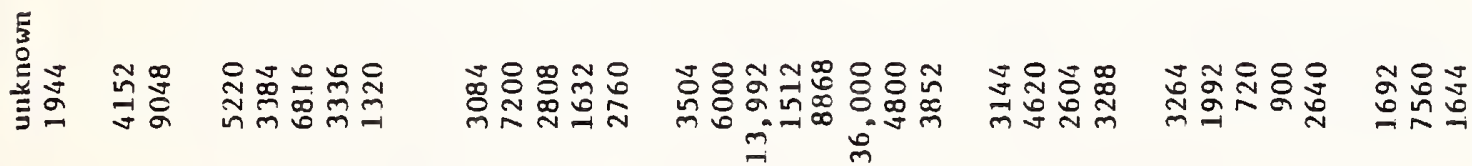

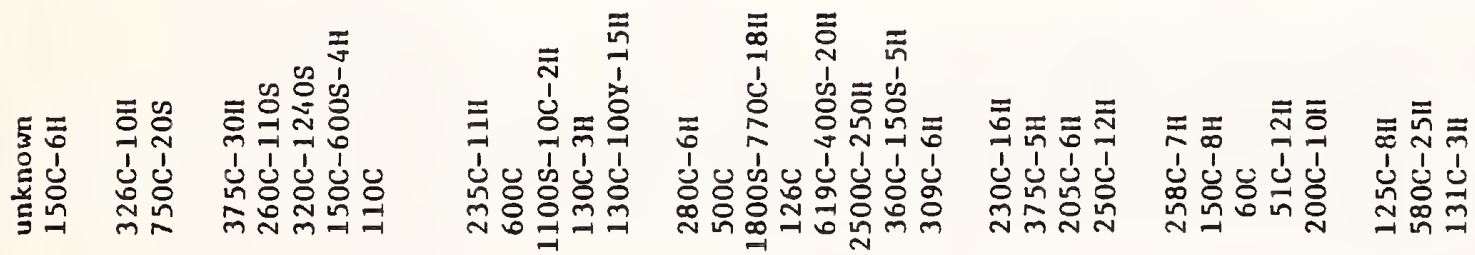

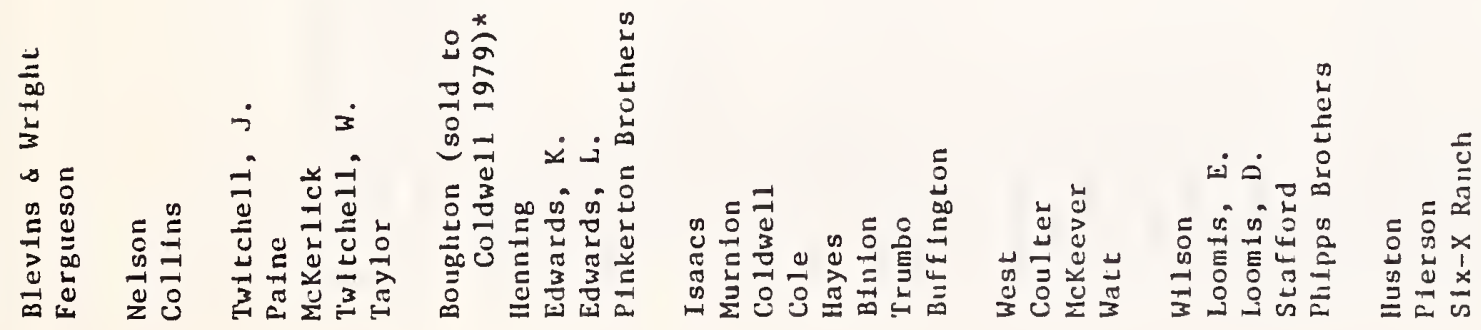




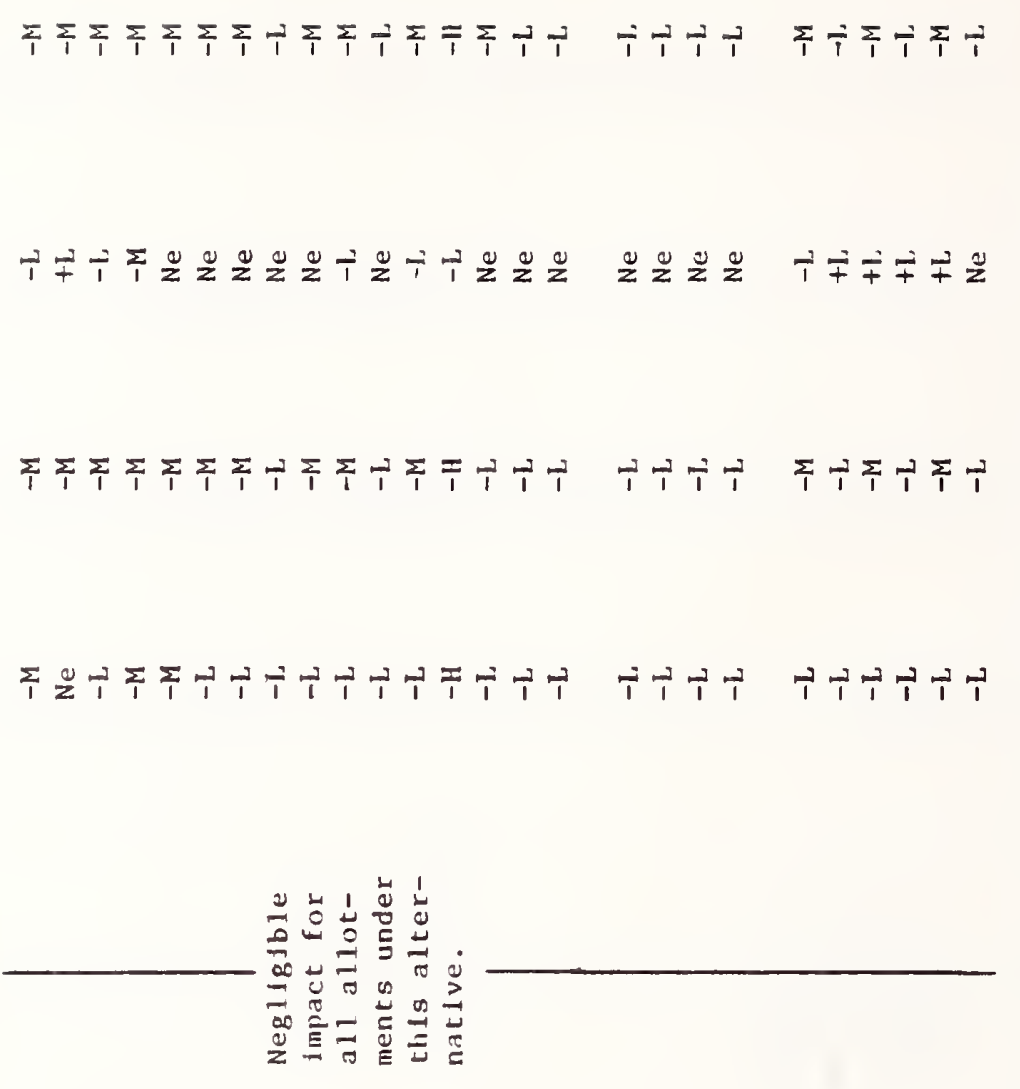

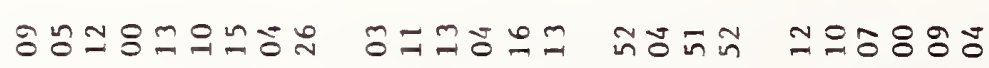

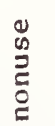

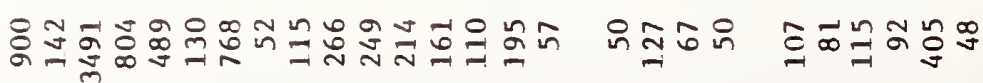

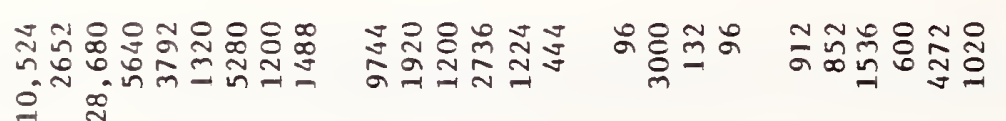

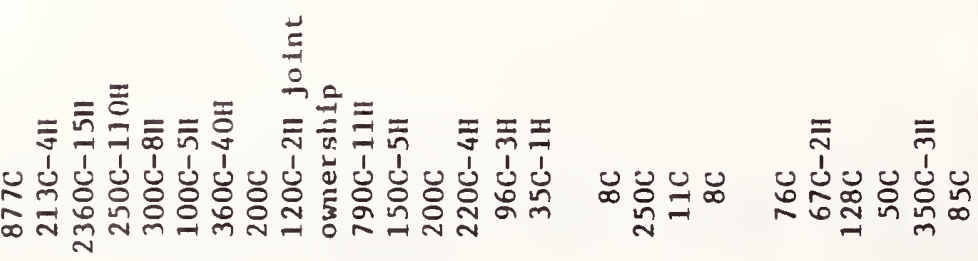

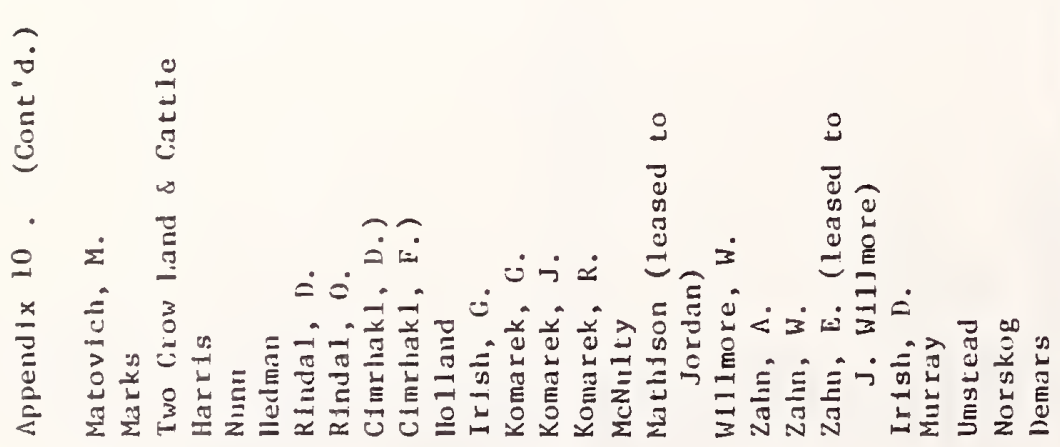




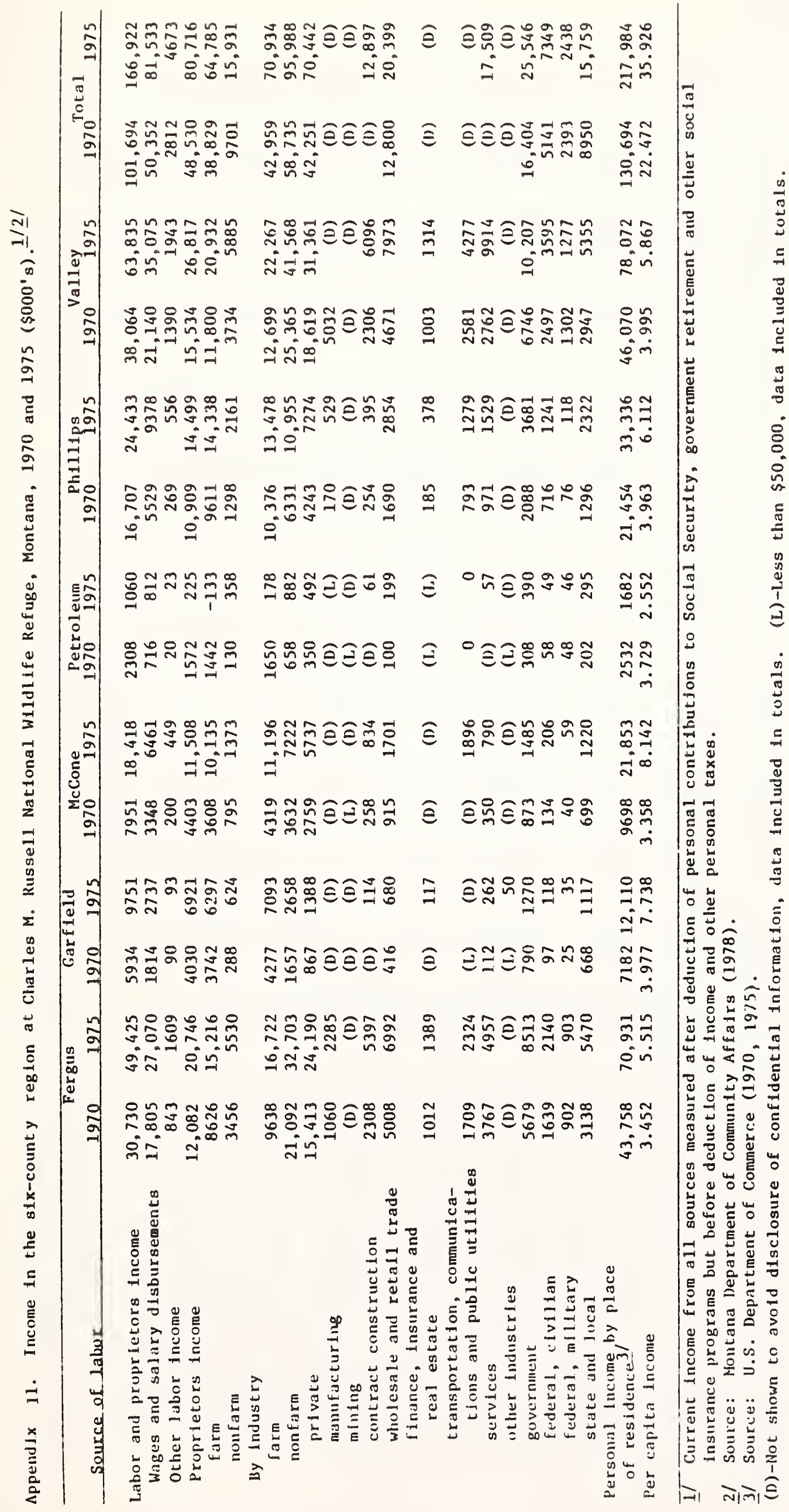

Appendix 11

象 


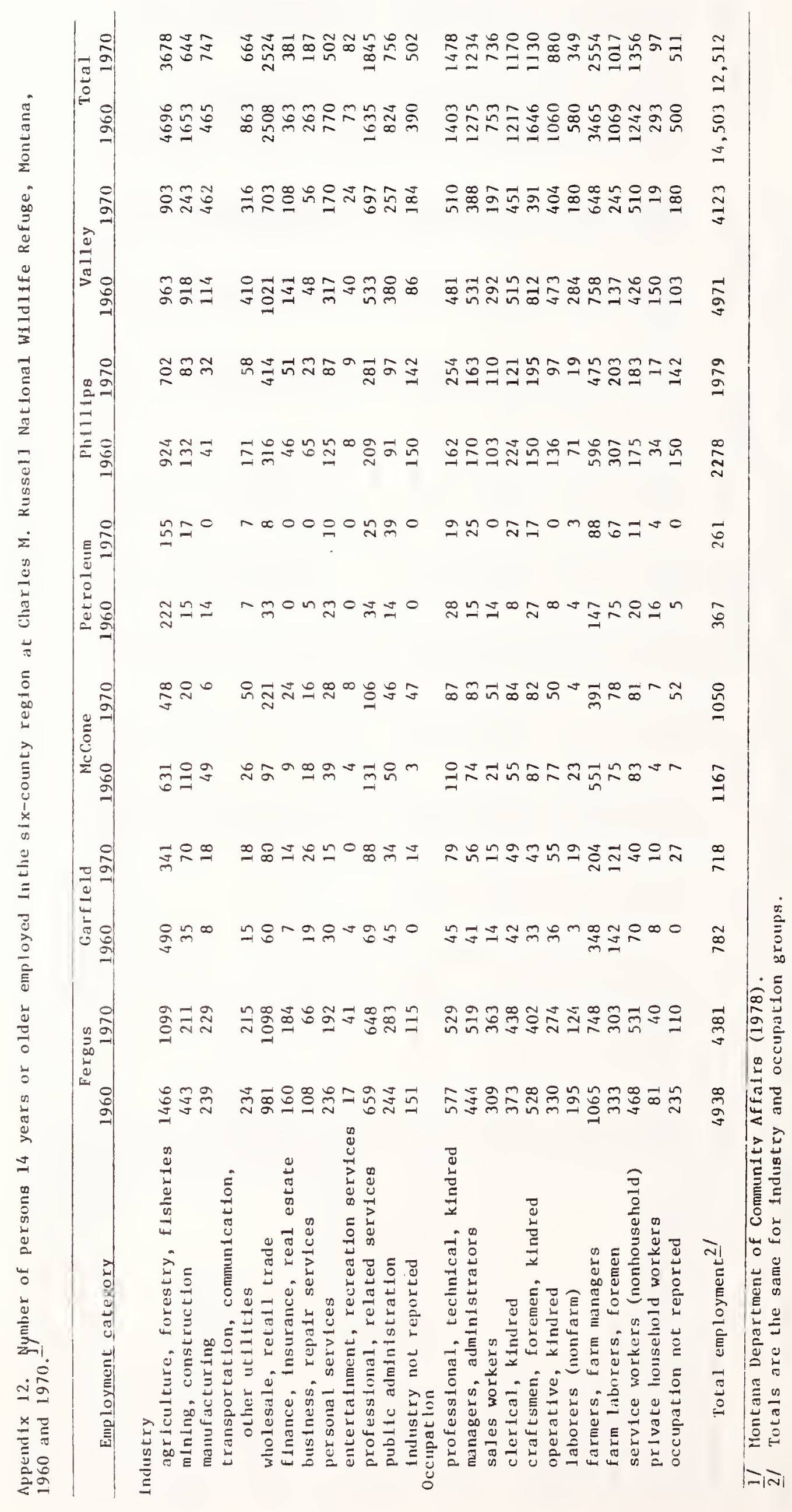


Appendix 13. Economic and social consequences methodology, Charles M. Russell National Wildlife Refuge, Montana.

The alternativés are comprised of land use or land management plans. Basically, a public agency (in this case FWS) is charged with allocation of public resources. When managing land for wildlife purposes, various combinations of fishing, hurting and general recreation activities are possible.

\section{Direct effects}

Direct economic effects are caused by the action and occur at the same time and place. However, to be classed as indirect, such effects would still have to be reasonably foreseeable.

With respect to grazing, direct effects were measured by the value of an AUM. Measuring the value of an AUM presents a problem because prices paid vary widely depending upon who is selling or being paid for the AUMs. Permittees on BLM lands and CMR pay \$1.89/AUM. On state lands in Montana, permittees pay from $\$ 3.54-\$ 3.74 /$ AUM. Private rates are at least $\$ 8.40 /$ AUM (Economics Statistics and Cooperative Service 1979), with rates in the Lewistown, Montana, area reported to range from \$10-\$20/AUM. Unless other costs are involved which make the different sources of AUMs noncomparable, permittees on CMR are receiving substantial federal subsidies.

Economic theory would indicate that free market transactions would place the proper value on goods or services. However, it appears that free market conditions do not exist with respect to granting and continuing grazing permits on CMR. Given the above problems, it was assumed that the direct economic effect of an AUM is the amount paid for actual use - $\$ 1.89$.

The direct economic effects of recreation activities were measured in dollars/visitor day. There are many sources available for estimating dollar values for recreation visitor days. Data for estimating values of hunter visitor days (Bureau of Land Management 1976) and nonhunter visitor days (Water Resources Council 1979) were obtained and utilized for this analysis.

Visitor day values utilized to estimate direct effects of CMR recreation activities on the six-county area are shown in Appendix Table 13-A. Using the same value, $\$ 2.10$, for many of the recreation activities is undoubtedly an oversimplification. During subsequent planning studies by FWS, visitor day values could be refined. The value of $\$ 2.10$ was obtained by taking the arithmetic mean of the minimum and maximum general recreation day values allowed by the Water Resource Council. Projections of visitor use on which economic calculations were based are shown in Appendix Table 17-A.

\section{Indirect effects}

Indirect economic effects are those effects which are caused by the action but are later in time or farther removed in distance. 
Appendix 13. (Cont'd.)

Appendix Table 13-A. Value/visitor day by type of recreation activity on the Charles M. Russell National Wildlife Refuge, Montana.

\begin{tabular}{lr}
\hline Activity & Value \\
\hline Cultural studies & 2.10 \\
Environmental education & 2.10 \\
Viewing scenery & 2.10 \\
Hunting: & 43.00 \\
Elk & 41.00 \\
Pronghorns & 24.00 \\
$\quad$ Mhitetailed-deer & 24.00 \\
$\quad$ Sharp-tailed grouse & 6.00 \\
Sage grouse & 6.00 \\
Trapping & 4.00 \\
Fishing: & \\
$\quad$ Paddlefish & 4.00 \\
Lake fish & 6.00 \\
Nature observation & 2.10 \\
Wildife photography & 2.10 \\
Backcountry travel (all) & 2.10 \\
Camping & 2.10 \\
All other activities & 2.10 \\
\hline
\end{tabular}


Appendix 13. (Cont'd.)

These effects would result from land use management changes at CMR. Lower livestock allocations would affect livestock sales and related economic activities in Phillips, Valley, McCone, Garfield, Fergus and Petroleum counties. This region was described in the Affected Environment. These indirect economic effects were estimated using a regional input-output model developed by the Forest Service in Missoula, Montana. This regional model is based on the national input-output model developed by the Department of Commerce. An input-output economic model describes an economic region, in this case a six-county area, by showing interrelationships between different sectors in the economic region. Outputs of one sector become inputs of other sectors. For example, the mining sector of an economic region would transfer (sell) given amounts of its output to the agriculture, construction, manufacturing and transportation sectors of the economic region. If more detail is required or desired, an economic region can be subdivided into more sectors.

This model employed changes in different economic parameters to estimate dollar effects. Because this model utilized only changes to measure effects of different plans, no data can be presented concerning impacts of the present level of livestock grazing on the regional economy. These activities do, however, contribute to the regional economy. In other words, No Action serves as the basis for comparison of the economic consequences associated with the other alternatives.

As shown in Appendix Table 13-B, indirect economic effects on labor (employment) in the region were measured in man-years while income was measured in dollars based on 1977 price levels. Figures are presented for 1978-85 and 1986-2000. The figures presented for recreation are due to increases in annual visitor days.

\section{Nonquantified Effects}

The various land management plans discussed in this EIS will have social effects which cannot be quantified. In some cases, even some of the visitor days that have been quantified and assigned a dollar value provide values to participants which go far beyond the small dollar amounts shown and defy quantification. Some activities, such as boating, camping, swimming and some types of hunting can be reasonably valued in dollar terms because of the existence of market transactions directly or indirectly related to these recreational activities. However, other activities, such as cultural studies, nature observation and visiting historic/archeological sites, fit into the category mentioned above where dollar quantification is a very inadequate measure of benefits and effects.

Likewise, changing AUM allotments can affect the lives of persons who have become accustomed to using federal lands for their ranching operations. Ignoring the issue of the legal status of permits and to what degree, if any, a permit constitutes a right, the permittees often perceive that their permits are rights rather than privileges. Thus, if 


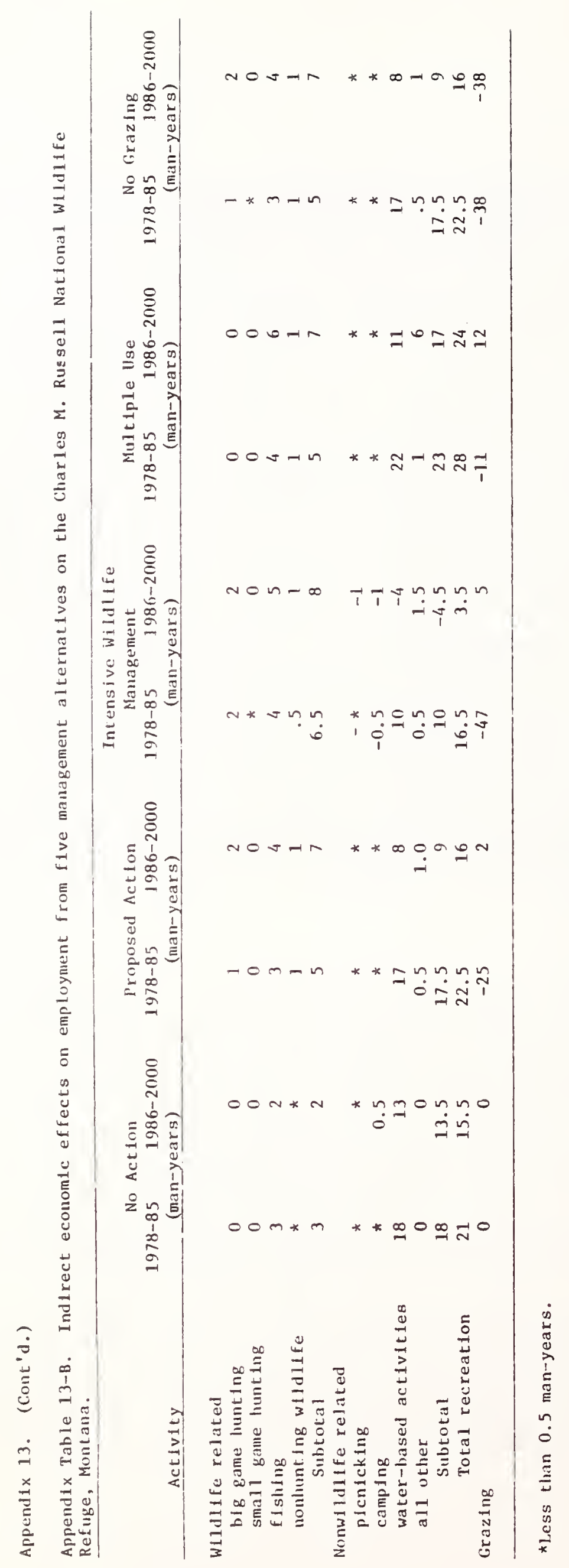




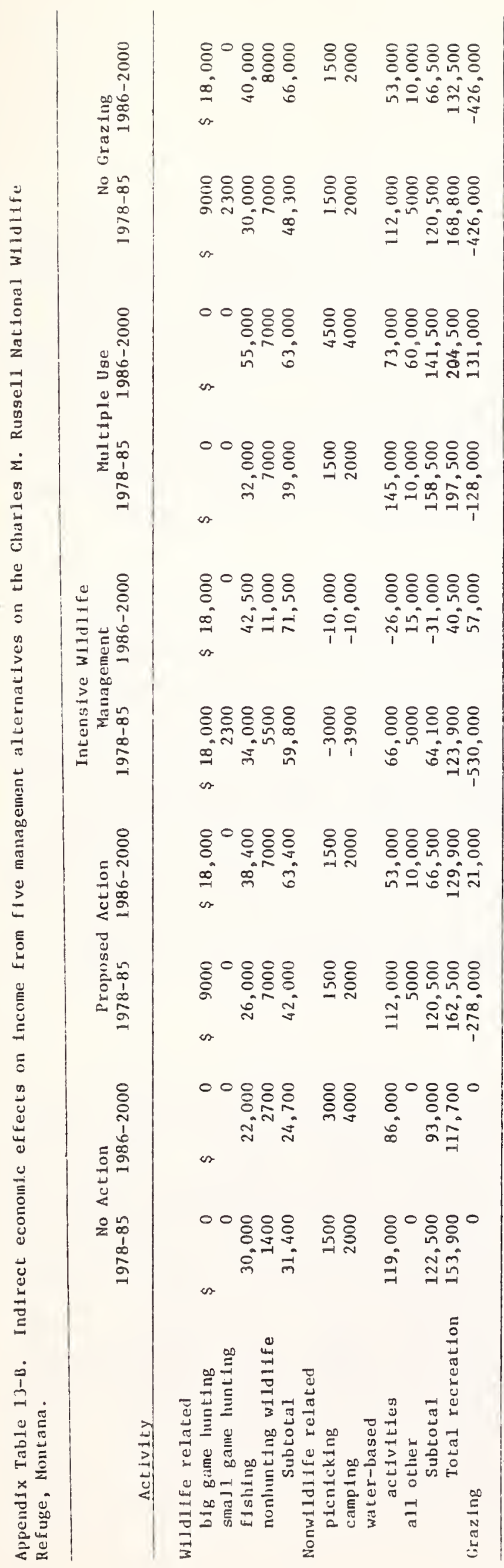


Appendix 13. (Cont'd.)

a permittee's AUM allotment is decreased, resentment and frustration would result. Because some ranchers have become dependent to varying degrees on utilizing public lands, they view any changes as threatening. If they are dependent to the extent that their use of public lands is crucial to the economic viability of their ranching operations, then changes in AUMs could affect their way of life. Such changes could make it necessary for these individuals to make drastic and painful changes in their lifestyles. Again, this discussion is not addressing issues of equity or legality but is only pointing out that some individuals and even groups will be affected positively by changes in land use management policies at CMR and others will be affected negatively and these changes and effects cannot always be expressed in dollar terms.

Benefit-cost analysis

In evaluating benefit-cost ratios, "...the weighing of the merits and drawbacks of the various alternatives need not be displayed in a monetary cost-benefit analysis and should not be when there are important qualitative considerations" (Council on Environmental Quality 1979). Undoubtedly, important qualitative considerations are present in this instance. Actually, managing land to protect and enhance wildlife involves primarily qualitative considerations. Thus, the direct or indirect economic benefits discussed below should not necessarily be compared directly to costs presented for purposes of determining economic viability of alternatives. Because costs can be estimated and projected with more certainty than benefits, they were discounted to present values. It is important to quantify and discount costs when possible, because these costs must be appropriated and budgeted by the federal government.

Present value

Figures used to compute present value are estimated cumulative annual changes. Thus, as annual visitor days change, cumulative direct economic effects change. However, because visitor days are annual, the proper method of analysis is that of an increasing annuity or series of annual payments. For example, an increase in direct economic effects of $\$ 132,100$ for the period $1979-85$ is equivalent to the annual amount growing by about $\$ 18,870 /$ year. The same method of analysis was applied to the increase from 1986-2000. The resulting present value, using a discount rate of $71 / 8$ percent, is $\$ 677,800$.

Appendix Table 13-C provides a summary of the economic effects of the five management alternatives discussed in this EIS. Operating and maintenance costs for recreation and grazing are current refuge figures provided by refuge personnel. 


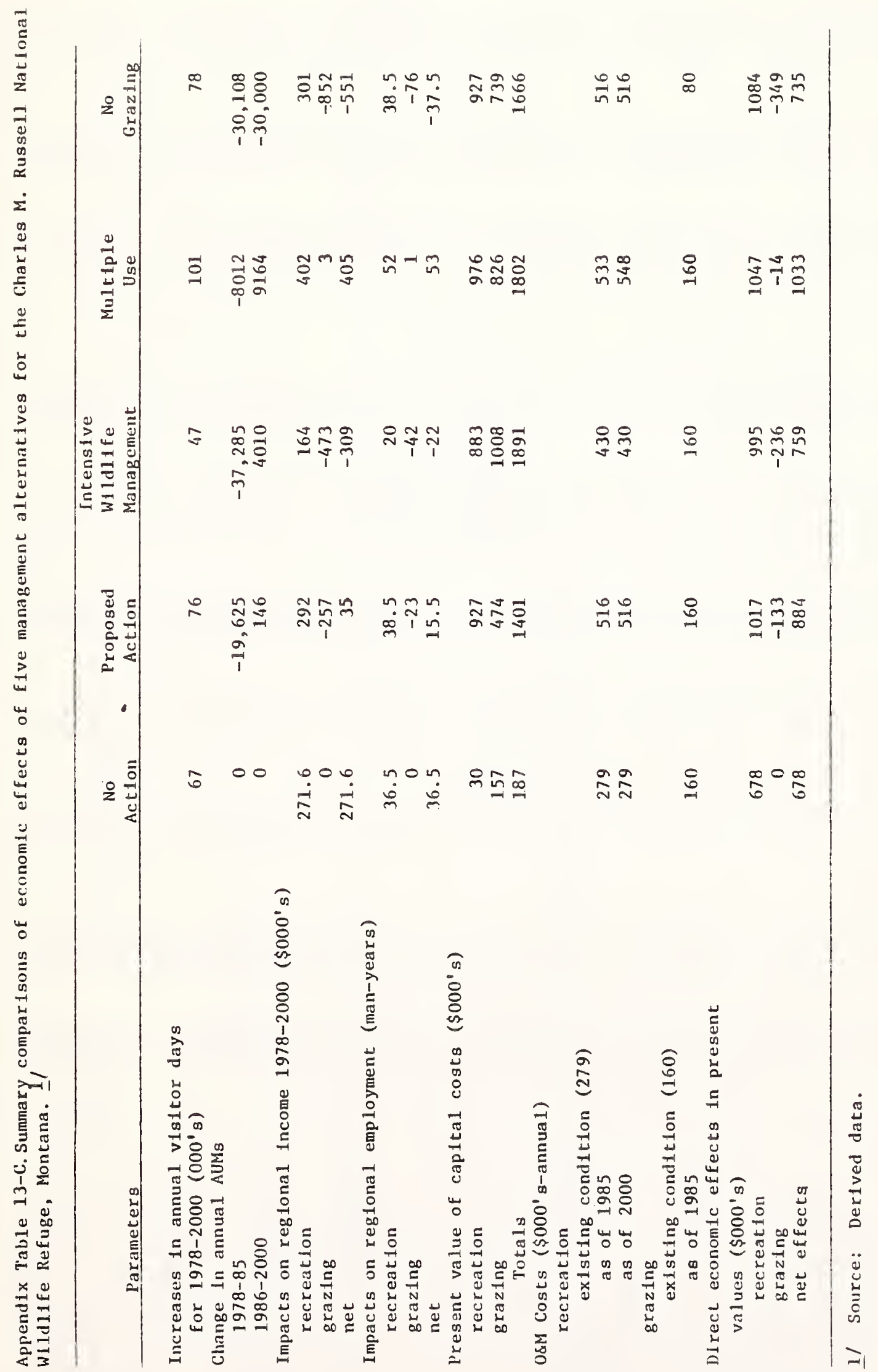




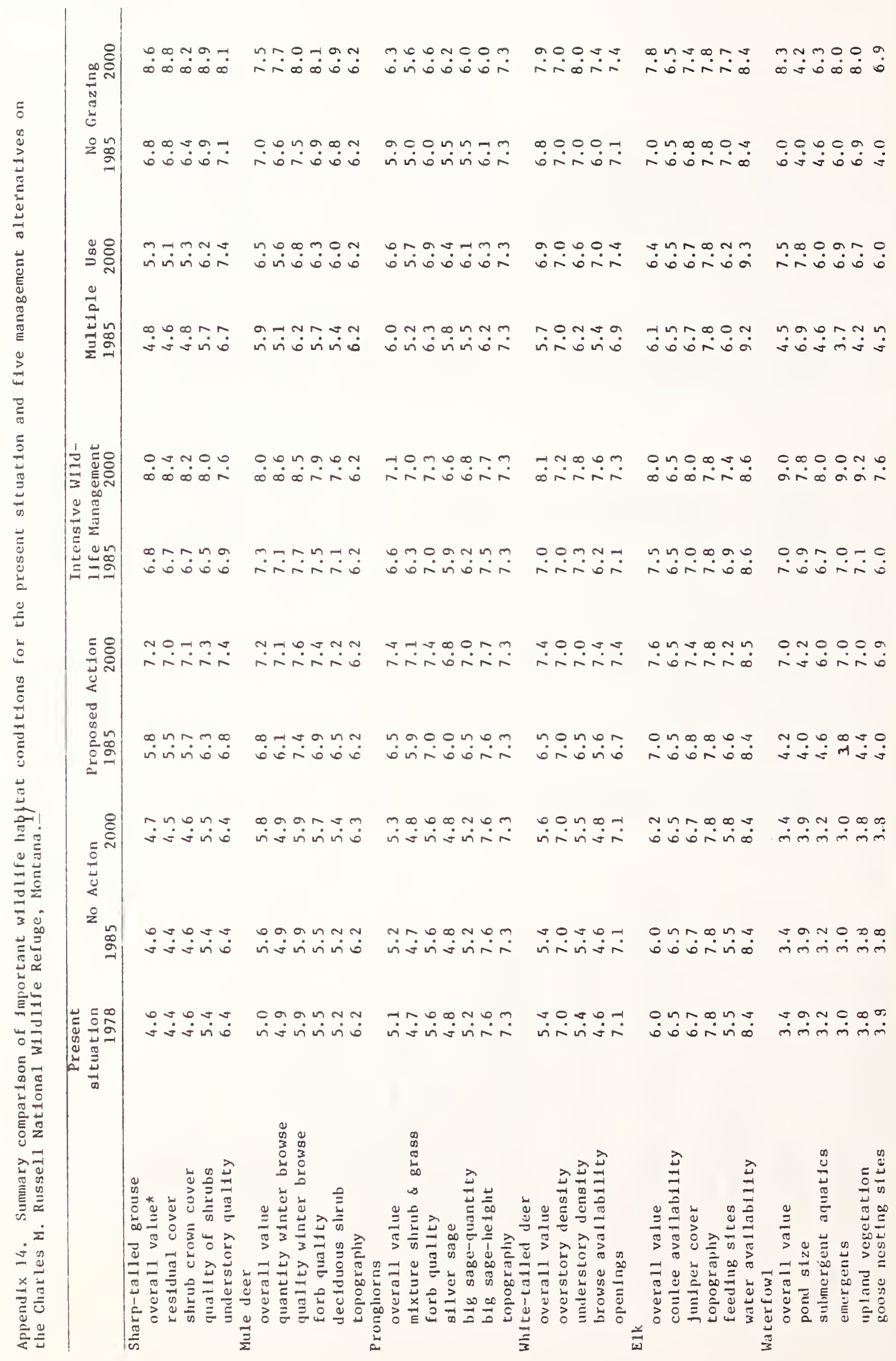




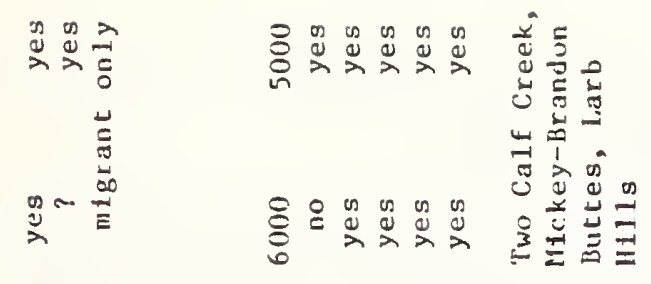

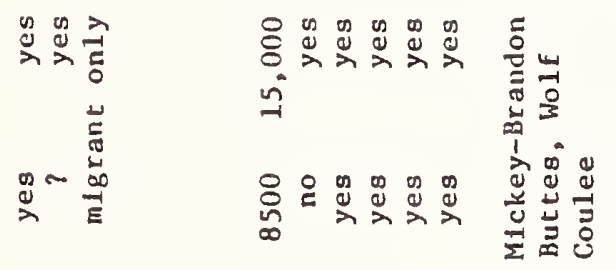

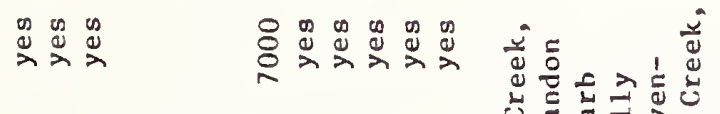

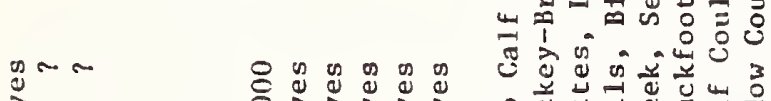

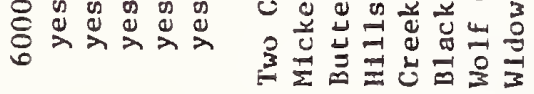

$\stackrel{\substack{\infty \\ \infty}}{\infty}$

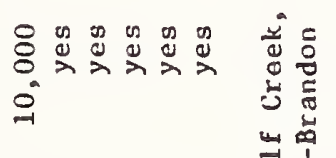

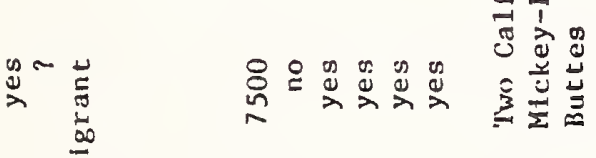

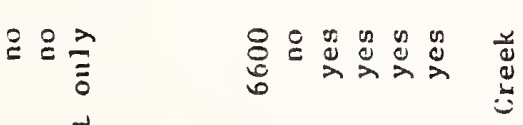

巳 莣

츰유를

崖

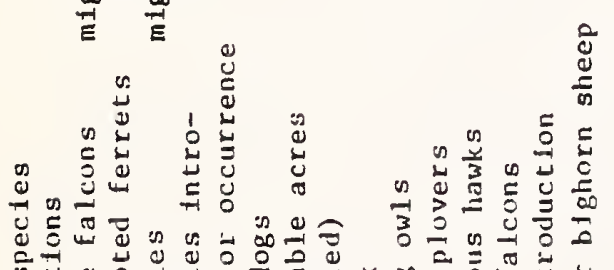
造

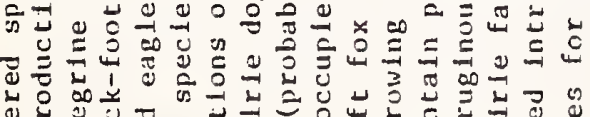

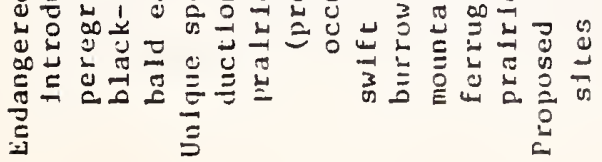


Appendix 15. Methodology employed in calculation of AUMs on Charles M. Russell Nationa-l Wildlife Refuge, Montana.

Mackie's work (1970) on mule deer, elk and cattle interrelationships provided much of the basis for allocating forage to wildlife and livestock on the refuge. The study took place on lands included within or bordering the refuge on its southwest boundary during 1960-64. Observations of elk, deer and cattle were made during all four seasons throughout the study period by activity such as feeding, bedding or loafing, standing alert or traveling, occurrence on various habitat types, slopes, exposures, distances from water and locations when first seen. A total of 11,581 observations of mule deer, 3489 of elk and 25, 107 of cattle were recorded during the study. Additionally, a similar study was made by knowles (1975) on the north side of the Missouri River in the Nichols Coulee area and provides additional supportive information.

Information obtained by Mackie and Knowles was used primarily to determine primary use areas for livestock and develop slope and water criteria for making adjustments to the recommended stocking rates provided in the SCS grazing guides. The objective in making slope and water adjustments was to provide a basis for stocking key livestock areas at a proper stocking rate. This would mean that more inaccessible areas which are seldom grazed by livestock would not be allocated on an across-the-board stocking rate basis in accordance with the grazing guides. Such a situation appears to have prevailed during the 1952-53 range survey, which set stocking rates maintained to the present time.

Primary livestock areas according to Mackie would include extensive, unbroken ridgetops and broad coulee bottoms within a mile of dependable water. Primary mule deer areas included moderate to steep slopes in the ponderosa pine-juniper habitat type and the big sagebluebunch wheatgrass habitat type on smaller ridgetops and along margins of more extensive ridges. Small to moderately extensive ridgetops dominated by the latter type in areas of light cattle use were apparent primary range areas for elk. Unlike cattle, Mackie felt that deer and elk were somewhat slope and water independent and that essentially all the wildlife refuge was available for their use. R. Ross (personal communication) indicated that large coulee bottoms and extensive ridgetops were primary livestock areas with the rougher, broken country better suited for wildlife.

Mackie's work provided that, "Management programs, numbers and management of livestock should be considered on the basis of forage available on primary range areas rather than on types of the entire area." In recognition of this statement, a slope-water matrix for livestock was developed using Mackie's criteria as the basis for allocating forage to livestock. Livestock would be allocated forage based upon recorded on-site observations of use and distribution. This would result in a proper stocking rate for the primary areas where cattle tend to congregate. A maximum livestock stocking rate was therefore determined using the slope-water criteria provided in Mackie's study. CMR was created for the primary benefit of wildlife with excess forage to be 
Appendix 15. (Cont'd.)

allocated to livestock. All AUMs within a section may be made available for wildlife if key or critical habitat is present to justify such an allocation. Conversely, all the AUMs may be allocated to livestock if there are no wildlife needs.

The slope-water matrix is provided in Appendix Table 15-A. Slope and water criteria are based upon actual observations of livestock during Mackie's study. The basis for the availability coefficient was determined with J. Nelson (personal communication). Nelson verified that the slope-water matrix was a reasonable model from which to derive information. Mackie reported that 82 percent of his total livestock observations were on slopes of 0-10 degrees, 13 percent 11-25 degrees, 4 percent 25-36 degrees and trace amounts over 35 degrees. His breakdowns by distance from water were:

$\begin{array}{lr}\text { Distance } & \text { Percent } \\ 0-\frac{1}{4} & 37 \\ \frac{1}{4}-\frac{1}{2} & 22 \\ \frac{1}{2}-3 / 4 & 20 \\ 3 / 4-1 & 11 \\ 1-2 & 10\end{array}$

A total of 90 percent of all observations of livestock was within one mile or less of water.

Availability coefficients were then determined by slope and water observation percentages for each slope category and distance factor for livestock. For example, slopes of 0-10 degrees were considered nonlimiting for livestock, as were distances of $0-\frac{1}{4}$ miles from water. The availability coefficient would be 1.00 or 100 percent of the total AUMs available to livestock. Since 82 percent of all observations were on slopes of 0-10 degrees, 18 percent would have occurred on slopes of greater than 11 degrees. Although 13 percent of the observations occurred on slopes of 11-25 degrees the figure used for the 11-25 degree category was $0.18 ; 18$ percent of the total observations occurred on slopes steeper than 11 degrees and it was concluded that 5 percent differential use on slopes of $26-35+$ degrees could just as likely occur on the 11-25 degree slopes.

Slope gradients for each section were determined by means of aerial photo interpretation and use of topographic maps with contour intervals. Slope gradients for each category on the slope-water matrix were measured and determined for each range site and tallied with water criteria to get acreages by each slope and water class. These acreages were then used to determine recommended stocking rates in accordance with SCS grazing guides and then to determine a maximum recommended livestock stocking guide based upon the slope-water matrix.

Distances to known water sources were obtained from questionnaires received from livestock permittees, information provided by FWS field personnel and locations of wells, ponds and springs shown on topographic maps and range survey aerial photos. Named creeks appearing on Geological Survey topographic maps as either permanent or seasonal streams were considered to be reliable water sources unless information provided 
Appendix 15. (Cont'd.)

Appendix Table 15-A. Slope-water matrix for livestock on the Charles M. Russell National Wildlife Refuge, Montana.

\begin{tabular}{|c|c|c|c|c|}
\hline $\begin{array}{l}\text { Degree of } \\
\text { slope }\end{array}$ & $\begin{array}{c}\text { Slope } \\
\text { coefficient }\end{array}$ & $\begin{array}{l}\text { Distance to } \\
\text { water (miles) }\end{array}$ & $\begin{array}{c}\text { Water } \\
\text { coefficient }\end{array}$ & $\begin{array}{l}\text { Availability } \\
\text { coefficient }\end{array}$ \\
\hline $0-10$ & 1.0 & $0-\frac{1}{4}$ & 1.0 & 1.0 \\
\hline $11-25$ & 0.18 & $0-\frac{1}{4}$ & 1.0 & 0.18 \\
\hline $26-35$ & 0.05 & $0-\frac{1}{4}$ & 1.0 & 0.05 \\
\hline $35+$ & 0.01 & $0-\frac{1}{4}$ & 1.0 & 0.01 \\
\hline $0-10$ & 1.0 & $\frac{1}{4}-\frac{1}{2}$ & 0.63 & 0.63 \\
\hline $11-25$ & 0.18 & $\frac{1}{4}-\frac{1}{2}$ & 0.63 & 0.11 \\
\hline $26-35$ & 0.05 & $\frac{1}{4}-\frac{1}{2}$ & 0.63 & 0.03 \\
\hline $35+$ & 0.01 & $\frac{1}{4}-\frac{1}{2}$ & 0.63 & 0.01 \\
\hline $0-10$ & 1.0 & $\frac{1}{2}-3 / 4$ & 0.41 & 0.41 \\
\hline $11-25$ & 0.18 & $\frac{1}{2}-3 / 4$ & 0.41 & 0.07 \\
\hline $26-35$ & 0.05 & $\frac{1}{2}-3 / 4$ & 0.41 & 0.02 \\
\hline $35+$ & 0.01 & $\frac{1}{2}-3 / 4$ & 0.41 & unsuitable \\
\hline $0-10$ & 1.0 & $3 / 4-1$ & 0.21 & 0.21 \\
\hline $11-25$ & 0.18 & $3 / 4-1$ & 0.21 & 0.04 \\
\hline $26-35$ & 0.05 & $3 / 4-1$ & 0.21 & 0.01 \\
\hline $35+$ & 0.01 & $3 / 4-1$ & 0.21 & unsuitable \\
\hline $0-10$ & 1.0 & $1-2$ & 0.10 & 0.10 \\
\hline $11-25$ & 0.18 & $1-2$ & 0.10 & 0.02 \\
\hline $26-35$ & 0.05 & $1-2$ & 0.10 & unsuitable \\
\hline $35+$ & 0.01 & $1-2$ & 0.10 & unsuitable \\
\hline
\end{tabular}


Appendix 15. (Cont'd.)

by field personnel indicated that the source was not utilized by livestock.

In examining range sites which would be considered to be key cattle areas, the following sites would be most important in terms of forage production and suitability:

1. overflow

2. sandy

3. silty

4. clay

5. thin hilly (0-10 degree slopes)

6. shallow clay (0-10 degree slopes)

7. panspots

8. dense clay

Present key deer and elk use areas would include the following sites:

1. clay (areas of light cattle use)

2. thin hilly

3. shallow clay

4. panspots (areas of light cattle use)

5. dense clay (areas of light cattle use)

6. shallow clay-shale complex

7. thin breaks

8. shale

Areas which may assume key importance for pronghorns, elk and deer for short periods may include:

1. saline lowland (emergency food)

2. thin breaks (security cover)

3. saline upland (emergency food)

4. badlands (security cover)

An attempt to quantify all criteria influencing distribution and use of forage by livestock and wildlife in terms of a mathematical equation is not easy. Other factors such as age class and breed of cattle may affect distribution patterns considerably. Yearlings are especially prone to be more slope and water independent than mature animals. Season of use may affect distribution patterns somewhat with animals tending to concentrate near water in hot weather and to range further from water during cooler fall weather. Information in present range publications indicates that the slope-water criteria presented above is comparable with data from other areas. The Forest Service (1964) indicated studies in the Stansbury Mountains in Utah revealed that most of the range classed as suitable was on slopes of 5-18 percent. Julander and Jeffrey (1964) found that cattle in Utah made little use of slopes greater than 30 percent, restricting most of their use to slopes of less than 10 percent. In Montana, Mueggler (1965) found that areas 200 yards up 30 or 60 percent slopes are occupied only 20 and 11 percent respectively as much as areas at the bottom. Slopes greater than 50 percent are generally considered unsuitable for livestock grazing (Bureau of Land Management 1976). 
Appendix 15. (Cont'd.)

In regard to water, Skovlin (1963) indicated that cattle will seldom graze more than $\frac{1}{2}$ mile from water where slopes are in excess of 40 percent. The Forest Service agrees that cattle should not be forced to go over $\frac{1}{2}$ mile from water in rough terrain or forced to go more than $2 \frac{1}{2}$ miles even on level terrain. Skovlin indicated cattle could travel up to 3 miles for water on gentle ground but would not be found that far away in summertime unless forage was gone for some distance about the water supply.

Soils limitations in the form of insufficient vegetation or erosive hazard provided a final consideration for AUM allocations. W. Larsen (personal communication) revealed certain soils mapping units which should be excluded from grazing. These mapping units were excluded from the AUM allocations during final compilations.

In the final analysis it must be remembered that the range site and condition inventory as presented in the SCS National Range Handbook is primarily a livestock-oriented inventory tool. As such, it has limitations when applied to wildlife needs. Animals such as elk, which have diets similar to cattle, can be considered along the same basic lines when it comes to allocating forage. Other needs such as security cover and interspersion of habitat needs are not so clear cut nor are the needs of deer and pronghorns or other less obvious wildlife species. However, it serves an important function as a management tool because it expresses present vegetation in terms of its potential climax. By examining what is present on the site and knowing wildlife needs for that site, a decision can be made as to the treatment to be employed to obtain the desired result. 
Appendix 16. Literature review for Charles M. Russell National Wildlife Refuge, Montana, range survey and wildlife-livestock interrelationships.

Consideration of interrelationships between livestock and wildlife is the basis for making recommendations for the benefit of all wildlife species on CMR. Such interrelationships have been much discussed by wildlife managers. Whereas intensive livestock grazing may be detrimental to wild ungulates, prescribed grazing treatments have been found to benefit other wildlife species. Complete elimination of livestock grazing on the refuge would eliminate a management tool the manager has at his disposal.

Smith (1977) stated, "Livestock grazing is the single most important factor limiting wildlife production in the West. It has been and continues to be administered without adequate consideration for wildlife, especially on federally owned lands." Mackie (1978) reported that very few studies have been attempted in which more than a few of the possible effects and processes of competition and other grazing impacts have been considered. Most measure only short-term effects. More importantly, few studies have ever attempted to compare behavior and performance of wild ungulate populations between similar adjacent grazed and ungrazed ranges. Mackie (1978) stated that livestock grazing did not become established as an important factor until the mid-1880's, with the resulting disruption of habitat and interspecific relationships between grazing ungulates being of rather recent occurrence. Mayr (1963) observed that intense competition can occur when two species initially come into contact or where a radical change in the environment has upset a previous balance. Because of this rather recent introduction of domestic livestock onto western rangelands, changes have occurred in vegetative conditions and composition at an accelerated rate along with the adaptations by wildlife species to adjust to these rapidly changing conditions.

Direct negative impacts resulting from livestock grazing cited by Mackie (1978) include direct competition for food, cover and space. Food requirements may be nearly identical, as between cattle and elk for most of the year, or may overlap for only short, often critical periods such as between cattle and deer during early spring growth of grasses and forbs. As grazing pressure increases there is a greater tendency for diet overlap to occur. Trampling becomes important with heavier livestock use. Pearson (1975) reported that direct forage consumption accounted for only 36-47 percent of the total herbage removed or lost where cattle are grazed with trampling accounting for the remainder. Season of use may affect livestock-wild ungulate interrelations according to Mackie (1978). Fall and spring range may be limited in extent; utilization by livestock of critical winter ranges after plant growth is completed may have an adverse impact. Alterations of cover by livestock may be a direct negative impact on wild ungulates when calving or fawning time occurs because of the tendency of these animals to have young in somewhat open, low shrub-grass cover types. Reductions or loss of cover could result in increased losses to predation or weather. 
Appendix 16. (Cont'd.)

Feeding behavior of wild ungulates may be greatly influenced by presence and grazing of livestock. McMahan (1964) observed that whitetailed deer used significantly more browse and generally more grass and less forbs on season-long livestock grazed pastures as compared with an ungrazed area. Knowles (1976) found heavier use of forbs, especially yellow sweet clover, by mule deer in an ungrazed pasture compared to a livestock grazed pasture where deer utilized more browse. Buechner (1950) reported that pronghorn diets may be greatly altered on overgrazed cattle range while overgrazed sheep range is unsuitable for pronghorn use. Distribution and movements of mule deer and elk in northcentral Montana may be influenced by occurrence of livestock on rangelands (Knowles 1975, 1976). Komberec (1976), McMahan (1966), Ellisor (1969), Firebaugh (1969), Dusek (1971) and Hood and Inglis (1974) suggested that livestock may interfere with deer use of all available habitats and may exclude deer use from some areas. Movements of elk from areas used by livestock have been reported by Jeffrey (1963), Dalke et al. (1965), Stevens (1966), Skovlin et al. (1968), Mackie (1970), Stark (1972) and Lonner (1975).

Mackie (1978) stated that indirect negative impacts by livestock on wildlife include gradual reductions in vigor of plants and quality of forage available, elimination or reduction in reproductive parts or vigor of plants such that future forage is diminished, elimination or reduction of important cover types and replacement by less favorable types and alterations or reductions in the kinds, quality or amounts of preferred plants through selective grazing. Where grazing is uniform or becomes so over large areas, vegetational diversity may be decreased.

Some individuals believe that livestock grazing is inherently or largely detrimental to wild ungulates as a result of these long term influences. Gallizioli (1977) considered overgrazing by livestock to be a major factor in destruction of deer and other wildlife habitat in the southwest. Severson and Bolt (1978) indicated that heavy livestock grazing on the northern Great Plains appears to have been a major factor in reduction of deciduous trees and shrubs along drainage ways. Such cover types may be critical to mule deer and other wildlife species of the area. Mackie (1978) indicated that diversity of cover types may be important, if not essential to mule deer. Irregular or spotty heavy grazing by livestock earlier may have contributed to this situation. More uniform distribution resulting from more intensive grazing systems or improved water distribution could result in less desirable conditions for deer.

The aspect of competition between wildlife and livestock was recognized by Smith and Julander (1953) as occurring in two forms forage competition, which occurred if the supply of a forage species used in common was not adequate to meet both species' requirements within proper use limits for the species and land use competition which may occur even with adequate forage but where lesser usage by one species would allow greater usage or numbers of the other species to occur. Mackie (1976) pointed out that it is quite difficult to effec- 
Appendix 16. (Cont'd.)

tively evaluate range relationships, competition and management needs of wild ungulates and other wildlife. He mentioned that he did not measure diet preferences but rather the response of deer and elk to livestock presence and grazing, noting that elk tended to avoid areas presently or previously grazed by cattle. He expressed interest in the potential of "social intolerance" as cited by Lonner (1975). Recent Missouri River breaks studies involving pastures where no livestock grazing occurred or on rested pastures in a rest-rotation system showed strong differences in wild ungulate distribution and use in relation to cattle distribution and use (Knowles 1975, Komberec 1976). Knowles (1975) observed that deer either moved or used all parts of their home range when cattle were turned into previously ungrazed pastures. Skovlin et al. (1968) reported that elk use was significantly less on range cohabitated with cattle than in areas where cattle use was restricted. Rates of elk use decreased as cattle stocking increased; however, moderate cattle stocking inhibited elk as much as heavy cattle stocking.

Skovlin et al. (1968) concluded that a light stocking rate promoted maximum sustained use of forage for livestock and wildlife. Where livestock production is the primary objective, moderate stocking would best fulfill the objective. Skovlin and Harris (1970) found that elk preferred season-long cattle ranges to deferred rotation ranges when cattle stocking was light. However, elk preferred heavily stocked rotation ranges to heavily stocked season-long ranges. Nelson and Burnell (1975) evaluated elk-cattle competition on pastures in a rotational grazing system and found that cattle and elk interacted significantly for both forage and space. Distribution patterns showed moderate overlap and diets overlapped significantly. Social interaction between the two groups resulted in elk leaving the pasture to which cattle were moved and elk were not observed to use the pasture used by cattle following cattle removal, except those areas within that pasture which were ungrazed by cattle.

Range improvements such as fencing and water developments often result in better range management as a result of improved distribution, more uniform utilization of forage and less damage to soil and range resources. Mackie (1978) pointed out that while this may benefit the range resource, effects on wild ungulates may be detrimental. Fences can interfere with migrations and access to habitats for wild animals. Direct mortality may also occur as a result of crossing fences. Papez (1976) found that 13 percent of 144 mule deer mortalities to factors other than hunting, crippling and winter kill were fence kills. As in the case of fencing, Mackie (1978) stated that in the development of water, "The expected effect may be the opposite by extending livestock use generally to previously little or only seasonally grazed areas and habitat types such that overlap or opportunities for overlap in use of resource are increased. This may be true on long continuously grazed ranges or on seasonally grazed ranges where stocking rates may be high." Additionally, uniform grazing patterns may result in the adverse effect of decreasing vegetation diversity of an area. 
Appendix 16. (Cont'd.)

Effects of various grazing livestock systems upon wild ungulates has been discussed to some extent earlier in this section. Skovlin et al. (1968) observed deer and elk use on dual use livestock-big game ranges and single use big game-only ranges. Big game made the greatest use of range where cattle did not graze. Deer had a tendency to utilize the deferred rotation pastures more than the season-long pastures. No significant use difference was found between single and dual-use - astures for deer or for the three stocking levels on the dual-use pastures. Elk, however, utilized the game-only pastures at a significantly higher level than on dual-use pastures. As cattle stocking increased on the dual-use ranges, elk use decreased significantly, apparently because of greater abundance of ungrazed forage in the deferred units. Under light stocking, elk preferred season-long pastures but under heavy stocking they preferred rotation pastures. As mentioned previously, light stocking was found to be the most desirable system.

Knowles (1975) found that in a rest-rotation grazing system in the Missouri Breaks mule deer distribution and movements appeared to be affected by grazing treatments and fawn production and survival may have been depressed in pastures receiving heavy grazing. Elk responded to the grazing by moving from grazed to ungrazed pastures without apparent effect. Heavy grazing use such as might be found on rest-rotation system grazed pastures leaves little residual vegetation and may increase the vulnerability of young animals to predation. Populations of microtine rodents may be reduced, forcing predators to seek alternate food sources, including wild ungulates.

Wittinger (1978) indicated that the dietary overlap between elk and deer was significant on rest-rotation pastures in Idaho. However, elk moved out of areas used by cattle, which lessened direct competition for forage but also limited the range area available to elk. No adverse effects on the elk population were noted during the study as a result of this situation.

Anderson and Scherzinger (1974) reported on a rest-rotation grazing system to improve winter elk forage in Oregon. Cattle were moved onto the range following range readiness and moved off the range at the midpoint of the growing season. The regrowth was then made available to wintering elk in the area. This sytem resulted in an increase in livestock forage because of improved range condition and an increase in elk use as a result of regrowth of high quality winter feed.

Mackie (1978) indicated that the often overlooked area of interspecific competition between wild ungulates may be intensified by livestock use. Elk tend to overlap both cattle and deer somewhat in terms of diet and distribution. Elk also tend to avoid cattle or areas grazed by cattle whenever possible. Areas not accessible to cattle are often highly important deer habitat areas. This tends to intensify competition between $e l k$ and deer. Changes in livestock practices may affect deer-elk relations in addition to deer-cattle and elk-cattle.

Beneficial impacts may result from dual use of rangeland by domestic livestock and wild ungulates. Use by livestock may result in 
Appendix 16. (Cont'd.)

greater diversity in the habitat, thus indirectly benefitting certain wildlife species. Overgrazing of many intermountain ranges ultimately benefited deer populations by allowing browse species to invade lands formerly occupied by grasses. Mackie (1978) stated that while heavy or abusive grazing during one season may be destructive to wild ungulate habitat values, lighter grazing or grazing at another season may increase the availability of plants or have other beneficial habitat impacts. Mackie indicated that while a livestock grazing impact may benefit one species it may detrimentally affect another. Longhurst et al. (1968, 1976) indicated that retrogressive succession from grasses and forbs to browse may have eliminated bighorn sheep while benefitting mule deer. Cosby (1978) reported that a planned livestock grazing system benefits both wildlife and the range in addition to providing livestock forage. Cosby recommended a rotation deferred grazing system to improve wildlife conditions. He mentioned a case of rotation by deer that coincides with livestock, where deer follow cattle to make use of succulent regrowth.

Anderson and Scherzinger (1974) indicated that elk habitat of the Bridge Creek Wildlife Management Area in Oregon was improved by implementation of a planned grazing program for livestock as well as improvement of range conditions. Elk made use of the regrowth on the management area following livestock removal. Cattle grazing was heavy enough to "top-off" grazed pastures but light enough to leave an adequate volume of forage for elk in all pastures following livestock removal.

Mackie (1978) concluded one report with the observation that the probability of conflict between wild ungulates and livestock is high and some negative impacts may be inescapable whenever livestock grazing occurs on range occupied by wild ungulates. He indicated that information is lacking with respect to impacts of grazing on wild ungulates. However, he cited numerous studies that have occurred in Montana and other western states which indicate that livestock grazing is detrimental to deer and elk. One study on nine state game ranges in Montana revealed that wintering elk numbers have increased an average of at least 100 percent following livestock removal.

Analysis of effects of livestock grazing upon ground nesting birds generally reveals that diversity of species and nesting densities are higher in undisturbed habitats than where grazing is allowed (Kirsch 1969). Quantity and quality of cover generally are adversely affected by grazing and trampling which affect density of nests and may affect nesting success because of predation on areas having reduced cover (Creston Valley Wildlife Management Authority 1974). Certain species such as the prairie horned lark, western meadowlark and mountain plover benefit from moderate grazing intensities, however (Smith 1940, Karuziak et a1. 1977).

Sisson (1976) indicated that sharp-tailed grouse in Nebraska preferred climax vegetation sites having relatively open canopy and sparse current growth with accumulation of plant litter. This probably 
Appendix 16. (Cont'd.)

indicated avoidance of cool season grasses and forbs as well as a preference for residual cover of warm season grasses. Accumulation of litter on favored sites was attributed to very light or no livestock grazing. Christenson (1971) concluded that uniform stands of vegetation at least 12 inches high or patches of vegetation at least 14 inches high were necessary for nesting. He proposed that regulation of grazing to maintain uniform stands of vegetation at least 12 inches high might substantially increase grouse populations. Sisson's conclusions in his report were that grouse requirements differ from those considered desirable from a livestock production standpoint. Interspersion of cover and habitat diversity are generally reduced by high intensity grazing systems. Sisson stated that diversity of vegetation resulting from selective grazing (as opposed to planned, high intensity grazing systems) by livestock and wild herbivores would be expected to contribute to long term stability and productivity of the system. This concept should be carefully considered in evaluating impacts of this type system versus intensive grazing systems.

Effects of grazing upon small mammals may vary by species and grazing intensity. Flinders and Hansen (1975) reported that blacktailed jackrabbits were most abundant on light to moderately grazed ranges. Turner (1969) reported that pocket gopher activities appeared greater on ungrazed than grazed ranges. Cover is essential to sage vole survival, whether it be growing or litter. According to Maser (1972), cover provides some needed protection from predators for small mammals which are active during daylight. Deer mice, being nocturnal, are not so limited by cover limitations. Other small mammals such as prairie dogs appear to thrive in areas which have been abused in the past. Once the tall perennial grasses have been removed, prairie dogs are able to maintain a lowered state of plant productivity and site quality through colonial activities.

In summary, an examination of the available literature reveals only few situations in which livestock grazing benefits wildlife. Deer and small mammal populations have often responded dramatically to range overuse which replaces climax species with those more palatable or conducive to populations of the benefitting wildlife species. In certain situations, removal of old, cured vegetation will make plant regrowth more palatable to wildlife species. Removal of excess, old forage will also allow establishment of new individual plants, thus improving range and watershed conditions. A look at the wildlife species priority list under which proposed management priorities will be developed for CMR reveals that mule deer, sharp-tailed grouse and elk will be the species having the greatest importance in terms of management impacts. All three species are affected to varying degrees by livestock grazing.

An analysis of the available literature concerning livestockwildlife interrelationships results in the following conclusions:

1. Grazing by livestock has relatively few beneficial impacts upon wildlife. 
Appendix 16. (Cont'd.)

2. Under light grazing intensities, livestock grazing is probably a "no-harm, no-good" situation in relation to most wildlife populations. Interspersion of habitat conditions which may result from light, selective livestock grazing may enhance certain wildlife species which require a vegetative mosaic for optimal habitat conditions.

3. Moderate and heavy livestock grazing intensities provide ever increasing detrimental effects upon most wildlife species. Certain species such as prairie dogs and mule deer may be positively affected by range overuse. Moderate livestock grazing rates would apply where wildlife values are not to be considered the major or dominant use.

4. Under light livestock grazing intensities, seasonal grazing appears to provide the best answer for CMR. Such a system should result in livestock activities being primarily confined to major coulee bottoms and ridgetops of gentle relief. Light stocking rates would help provide proper use of such areas; the majority of the refuge, which contains steeper topography, would be reserved for wildlife use.

5. Under moderate grazing intensities, implementation of an intensive grazing system such as rest-rotation would appear to offer the best solution for wildife populations. A three or four pasture restrotation system would provide sanctuary for wildlife on the rested pastures when livestock are present on the pasture to be grazed. Such a system would require development of additional water facilities and more fencing, both of which may be detrimental to wildlife. Water development allows better distribution of cattle and allows them to penetrate sanctuaries formerly reserved for wildlife. Fencing impedes wildlife movements. If the decision is made to implement such a system, the "stocking rate is based on the forage that is produced on the portion of the range that is open for use each year" (Hormay 1970). Moderate grazing intensities should be applied where multiple use concepts are to be employed.

6. Livestock grazing should be regarded as a management tool to enhance wildlife populations. Flexibility should be an inherent part of the system; numbers should be modified in part by forage production during a given year. Introduction of heavier than normal livestock numbers temporarily into a pasture to remove rank vegetation could also be a management objective.

The feeling as to reasons why a wildlife refuge should contain domestic livestock is perhaps best summarized by Murie (1935): "I might mention that cattle here and there, if not so numerous that one is apprehensive about the range, also fit into the picture. There is something picturesque about the old time cattle ranch, although the outdoorsmen would not like to have that feature to pervade the entire field. Simplicity on a grand scale is the keynote of this whole outdoor picture." 
Appendix 17. Methodology for estimating visitor use on the Charles M. Russell National Wildlife Refuge, Montana.

Although estimates of visitor use on the refuge have been made in the past, reliability of this information is tempered by a number of variables. The refuge is accessible by road, trail, horseback, foot, water or other means at many locations. Only in a few areas is access controllable, such as at developed recreation areas. Thus, it is almost impossible to sample the many access routes and determine the amount of use the area receives. This is further complicated by the fact that three major highways cross the refuge: State Highways 24 and 117 on the east and US Highway 191 on the west.

For purposes of this study, total visitation was estimated for dispersed recreation areas, developed recreation areas and the Upper Missouri National Wild and Scenic River. Dispersed recreation areas constitute the bulk of undeveloped land and water surface on the refuge, as contrasted to developed recreation areas administered by COE and MDFW\&P. The nationally designated wild and scenic river segment at the west end of the refuge is administered by BLM.

Dispersed area visitation

Dispersed areas were divided by the level of use they receive: high, medium or low. These areas were determined by traffic count data, field observations and professional judgment. Traffic count data were only available for a three-month period during the summer involving four traffic counters. Reductions were made in total counts to compensate for traffic not directly involved in recreation. Visitation for each type of area was calculated with these data, assuming that the amount of use they receive is in proportion to the volume of traffic on major highways crossing the refuge.

Participation rate factors derived from a preliminary survey of recreation use on the refuge (Fish and Wildlife Service 1978) were then applied to the estimate of visitors on dispersed use areas to obtain a measure of current visitation by activity (activity days). Based on survey data, activity days were converted to recreation days using a factor of 3.8 , which represents the average number of activities in which an individual participates while visiting the refuge. Recreation days were then divided in half to obtain the number of visitor days, since a visitor day is half as long as a recreation day.

Since the year in which the previously referenced visitor survey was conducted was atypical due to bad weather, which restricted access by sportsmen, hunting and fishing, use estimates were related to the Montana Statewide Comprehensive Outdoor Recreation Plan (Montana Department of Fish and Game 1978) for State Planning Regions 4, 6 and 7.

Developed area visitation

Since only partial information was available from COE on amount of visitation at developed recreation areas, it was necessary to estimate 
Appendix 17. (Cont'd.)

use at these areas. In calculating this visitation, a distinction was made between nearby recreation areas and outlying recreation areas. The primary difference between these two types relates to proximity of the areas to local service establishments. Nearby areas are those located close to the town of Fort Peck where there are a number of opportunities to obtain food, lodging, entertainment and related services. In contrast, outlying areas are from 10-40 miles or more from the nearest service facilities.

Using traffic count data compiled by COE (R. King personal communication), the number of total counts recorded at nearby and outlying areas was determined. It was estimated that a visitor to nearby areas would make an average of six trips to and from local service facilities during his stay, while those who visit outlying areas would make a minimum of two trips during their stay.

Dividing traffic count data for nearby and outlying areas by the average number of trips made in and out by each vehicle provided an estimate of the number of vehicles at COE and State facilities. Multiplying the resulting figure times 2.68, which represents the average number of people/vehicle (Fish and Wildlife Service 1978), yielded an approximation of the number of visitors. As with dispersed areas, participation rate factors were applied to this visitation to obtain estimates of use by activity and then converted to visitor days.

Wild and Scenic River visitation

Based on BLM data ( $W$. Cutler personal communication) it was assumed that about 30 percent of the floaters on the Upper Missouri National Wild and Scenic River traverse that portion of the river through the refuge during the primary use season. River use during the balance of the year is unknown but thought to be minor.

\section{Projections of visitation}

Due to growing scarcity and rising cost of fuel for transportation as well as numerous competing recreation resources available outside CMR, the impact of recreationists on the refuge in future years was assumed to be primarily dependent on local and regional changes in population. Thus, estimates of future use on the refuge under the Proposed Action alternative were based on anticipated population increases in the 150-mile area immediately surrounding the refuge (Appendix Table 17-A). Anticipated visitation under the other alternatives was based on variation in facilities and opportunities that would be provided by each. It was assumed that this use would be divided between dispersed areas, developed areas and the wild river in about the same proportion as 1978 . 


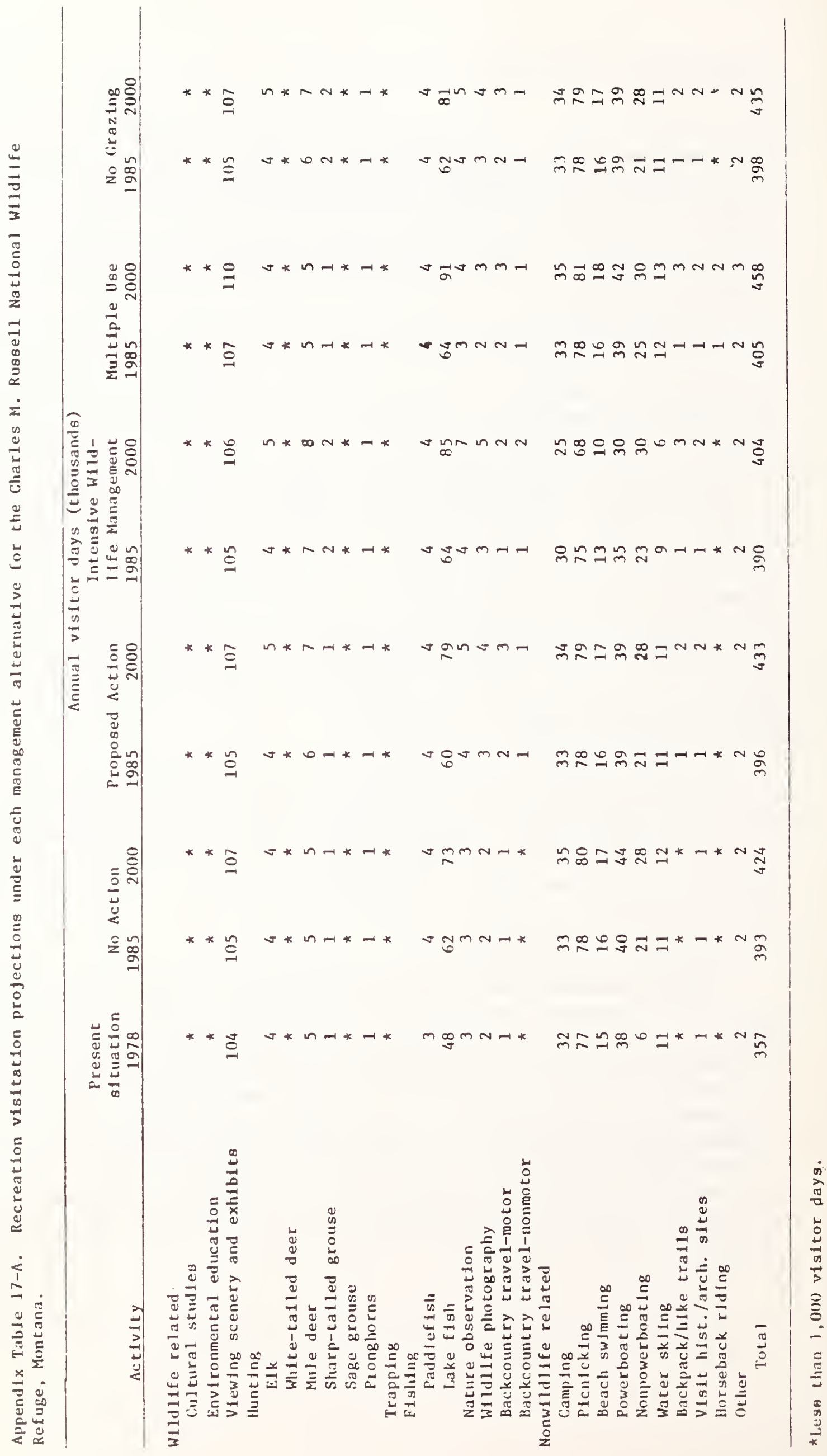




\section{GLOSSARY}

ALLOTMENT. An area designated for use of a prescribed number and kind of livestock under a plan of management.

ANIMAL-UNIT MONTH (AUM). The amount of feed or forage required by an animal-unit for one month (approximately 1000 pounds of air dry forage).

CARRYING CAPACITY. The maximum number of animals an area can support without inducing damage to vegetation or related resources. It may vary from year to year on the same area due to fluctuating forage production.

CLASS OF LIVESTOCK. Age, sex-group or species of livestock.

COMMON ALLOTMENT. An allotment upon which several permittees graze livestock in common.

CONTINUOUS GRAZING. The grazing of a specific unit by livestock throughout the year or for that part of the year during which grazing is feasible. The term is not necessarily synonymous with yearlong grazing.

CROSS-FOSTERING. Putting eggs or young of one species of bird into the nest of a second species to be raised by the adopting parents.

DANCING GROUND. A traditional gathering site where the courtship ritual between male and female sharp-tailed grouse occurs. Nesting and rearing areas are almost always close by.

DIRECT ECONOMIC EFFECT. Income generated only by the economic sector (such as the livestock industry) to which a reference is made.

DISCOUNTED. Brought back to a present equivalent value, interest rate used was $71 / 8$ percent.

DISPERSED RECREATION USE. Scattered recreation activity that occurs away from developed recreation areas.

DNC. Cover such as a mix of legumes and grasses used by waterfowl for nesting.

ECOTONE. A transition area of vegetation between two communities, having characteristics of both kinds of neighboring vegetation as well as characteristics of its own. Varies in width depending on site and climatic factors.

EDGE EFFECT. The influence of one adjoining plant community upon the margin of another affecting the composition and density of the population of plants and animals. 
EMERGENT. Rooted vegetation which grows above the surface of the water.

ENDANGERED SPECIES. Any species which is in danger of extinction throughout all or a significant portion of its range.

FALL STAGING AREA. An area where a number of individual animals of a species temporarily congregate in late fall before snow, ice and cold weather forces them to winter habitat. During mild winters, wildlife may stay in staging areas the entire season.

HEAVY GRAZING. More than 50 percent utilization of annual available forage.

HEDGED CONDITION. Shrubs which resemble trimmed hedges, usually because of browsing by herbivores.

INDIRECT ECONOMIC EFFECT. Income produced in one or more economic sectors (such as retail trade) by the receipt of income in another economic sector (such as the livestock industry).

LIGHT GRAZING. Between 0-35 percent utilization of annual available forage.

LITTORAL. Shore zone between high and low water marks characterized by vegetation development which is used for stabilization of the shoreline and spawning for various fish species.

MODERATE GRAZING. Between 35-50 percent utilization of annual available forage.

NATIONAL NATURAL LANDMARK. An area that possesses exceptional value or quality in illustrating or interpreting the national heritage of our nation.

NATIONAL REGISTER OF HISTORIC PLACES. The official list of the nation's cultural resources worthy of preservation.

NATURAL AREA. An area set aside indefinitely to preserve a representative unit of a major forest, grassland, or wetland type primarily for the purposes of science, research, or education.

PARENT MATERIAL. Unconsolidated mineral or organic matter from which soils are developed.

PRESENT VALUE. An amount of money which will become a given amount at a stated time in the future. For example, at 10 percent interest \$100 will grow to $\$ 110$ in one year; therefore, the present value of $\$ 110$ one year from now at 10 percent interest is $\$ 100$. If the end product is a series of payments, the present value is the amount that will result in the sums of that series. 
RANGE IMPROVEMENT. 1) Any structure or excavation to facilitate management of range or livestock. 2) Any practice designed to improve range condition or facilitate more efficient utilization of the range. 3) An increase in the grazing capacity of range, i.e., improvement in range condition.

RANGE READINESS. The defined stage of plant growth at which grazing may begin under a specific management plan without permanent damage to vegetation or soil. Usually applied to seasonal range.

RANGE SITE. A distinctive kind of rangeland, which in the absence of abnormal disturbance and physical site deterioration, has the potential to support a native plant community typified by an association of species different from that of other sites. This differentiation is based upon significant differences in kind or proportion of species, or total productivity.

RESEARCH NATURAL AREA. An area on which natural features and processes are preserved with minimal human intervention for research and educational purposes. This designation differs from other classifications such as wilderness or refuge, in that the latter designations often have broader use-management objectives than the preservation/ scientific applications of the research natural area.

RESIDUAL COVER. Vegetation, primarily grasses of sufficient height and density to hide birds from view at a level of three feet above the ground.

RIPPING (RANGE). The mechanical penetration and shearing of range soils to depths of 8 to 18 inches for the purpose of breaking hardpan layers to facilitate penetration of plant roots, water, organic matter and nutrients. A range improvement practice used where native grasses of a rhizomatous nature can spread into the ripped soil.

ROTATION GRAZING. System of pasture utilization embracing short periods of grazing followed by periods of rest for herbage recovery during the same season. Variations of rotation grazing include deferred rotation and rest-rotation systems.

SECTION 7 CONSULTATION. Consultation with personnel of the US Fish and Wildlife Service to determine environmental effects on species listed as endangered or threatened under Section 7 of the Endangered Species Act.

SELF-FURNISHED AUMs. Livestock AUMs which are derived from privately owned or state leased land within the CMR boundary. The number of AUMs authorized is generally reflected on the grazing permit, but no fee is assessed by FWS for grazing. 
STRUTTING GROUND. A traditional gathering site where the courtship ritual between male and female sage grouse occurs. Nesting and rearing areas are almost always close by.

THREATENED SPECIES. Any species which is likely to become an endangered species within the foreseeable future throughout all or a significant portion of its range.

VISITOR CONTACT CENTER (VCC). A manned facility designed to provide general information.

VISITOR CONTACT STATION (VCS). An unmanned facility designed for dispersing information.

VISITOR DAY. Participation by an individual in one or more recreation activities during all or part of a 12-hour period.

VISITOR INTERPRETIVE CENTER (VIC). A structure designed for full-scale interpretation using exhibits, displays and other media.

WILDERNESS. An area which has not been seriously altered by man set aside by legislative action to preserve a representative unit of a major forest, grassland, or other land classification type. 
$\underline{\mathrm{A}}$

Access, $\mathrm{x}, \mathrm{xi}, 8,13,14,16,20$, $27,50,52,67,78,89,93,94$

Activities (see recreation activities)

Aerial surveys (see surveys) Aircraft landings, 13, 16,78

Animal damage control (ADC), $\mathrm{x}, \mathrm{xi}, \mathrm{xii}, 7,12,19,21,24,25$, $65,71,84,90,91,100$

Aridisols (see soils)

Assumptions, 61

\section{$\underline{B}$}

Backcountry (nonmotorized) trail (see trails)

Big sage-greasewood-grassland, viii, 5, 21, 39, 73

Bison grazing (see grazing)

Brood (see ponds)

Burning (see fire management)

\section{$\underline{\mathrm{C}}$}

Canoe trail (see trails)

Climate, 33

Climax vegetation, ix,41,85, 99,100

CMR goals (see goals)

Constraints, 9, 11, 16, 17, 26

Continuous grazing (see grazing)

Competing recreation resources, 50

Competition (see livestockwildlife interrelationships)

Crop depredations, 5,11,44

Cross-fostering, 49

Cultivated land, 39,41

Cultural resources, $3,4,6,8,13-$ $16,20,22,25,27,50,61,67,77$, $86,87,93,100,101$

archeological, 67,77

historical, 14,22,67,77,86

paleontologica1, 67,77
$\underline{\mathrm{D}}$

Deferred-rotation system

(see grazing systems)

Direct economic effects, 67,68,78, $79,87,94,101,103$

Domestic sheep, 11,72

E

Early spring use (see grazing)

Ecotone, 49

Endangered species, ix, x, xii,4,7, $10,18,21,33,50,77$

Energy resources, viii, 36,57

Entisols (see soils)

Environmental education study areas, 4, 6, 14

Emergent vegetation, 41,90

Executive orders, viii, 9,16,24,26,31

\section{$\underline{F}$}

Farming, $x, x i, 7,9,11,16,19,21,24$ $26,55,57,73,83$

Fire management, xi, 3,11, 19,21,63, $70,81,89,97,99$

wildfire, $x, x i 1,7,11,19,21,63$, $70,81,97$

prescribed burns, $x, x i, x i i, 7,10$, $11,18,19,21,24,73,82,84,85,91$, $94,99,101$

Fisheries (resource \& management), $7,12,13,19,21,24,45,74,84,91$

Fishing, 4, 6, 8, 9, 12, 52

Forage allocations, 7,12,19,21,24, $26,65,67,74,77,81,84,91,94,97,101$

Fort Peck Dam, 13,26,31,34,38

\section{$\underline{G}$}

Geology, 34

Goals (CMR) , 4, 9

Grazing (see also):

bison grazing, 75,85

continuous grazing, 9,12,26,42, $74,76,90,92$ 
early spring use, $12,13,66$

heavy grazing, 66,84

light grazing, iv, 9, 12, 72 75,76

livestock grazing, 7,9,12, $16,18,19,90$

moderate grazing, $19,72,75$ 84

no grazing areas, $16,17,21$

prescription grazing, 10 , $12,18,21,72,73,74,76,82$, $84,85,100$

seasonal grazing, 9,12,26, $42,74,90,92$

yearlong grazing, 42, 66, 74

Grazing allotments, ix, 12,42, 57,92

Grazing systems

deferred-rotation, xi,12,13, $22,42,91,92$

rest-rotation, $x i, 12,13,22$ $42,89,91,92,100$

$\underline{\mathrm{H}}$

Habitat evaluation procedures, 10 (HEP) (see also surveys)

Habitat treatments

cooperative farming (see farming)

exclosure construction, $\mathrm{x}, \mathrm{xi}$, xii, 11, 19, 21, 24, 70, 73, 76

$81,83,97,99$

livestock grazing (see grazing)

prescribed burn (see prescribed burns under fire management

ripping, $x, x i, x i i, 9,10,11$, $13,20,22,25,70,76,77,81$, $85,86,89,92,94,97,100,101$

shrub plantings, $x, x i, x i i, 9$, $11,18,19,21,24,70,73,81$

$82,85,91,99$

tree plantings, xi, xii, 18, 19

$21,24,83,100$

Handicapped recreation

facilities, 3

High density recreation areas, $\mathrm{x}, \mathrm{xi}, \mathrm{xi}, \mathrm{,} 20,22,87$

Historic tour route, 14,77,
Hunting, 4, 6, 8, 9, 16, 52, 86, 94,101

\section{I}

Income (see socioeconomics)

Indirect economic effects, 67 , $68,87,95,103$

Inholdings, xi, xii, 1, 18, 19,26, 31,84

Interpretive facilities, $\mathrm{x}, 4,6$, $14,27,67,78,94$

nature trail, $x i, 14,20$

visitor contact station, 8,14, 78

exhibits, 14,78

\section{L}

Land purchases, 11

Lewis and Clark Trail, 22

Livestock grazing (see grazing)

Livestock reductions, $\mathrm{x}, 10,12$, $17,18,20,21,24,70,71,74,78$, $83,84,86,87,89,100,101$

Livestock-wildlife interrelationships, $12,20,65,66,71,75,76$ $82,90,92,98$

Long-term impacts, 61,63

Low density recreation areas, $x$, xi, xii, 20, 22, 87, 94

\section{$\underline{M}$}

Management responsibilities, 1 Memorandum of Agreement, i, 33 Mission (CMR), 4

Missouri River, 8,13,21,22,31, $34,35,38,64,73,77,83$

Mitigating Measures, 8,16,20,22, 25 Mollisols (see soils)

$\underline{\mathrm{N}}$

National natural landmarks, ix, 77

National policy, 9

National Register of Historic Places, 16,67, 77

Nature trail (see interpretive facilities)

Nest structures, 7,21 
Noneconomic effects, 68, $79,87,95,103$

Non-wildlife-oriented recreation, 6,67

\section{$\underline{0}$}

Objective (National WildIife Refuge System), 33

\section{$\underline{P}$}

Parent material, 37

Perimeter shoreline scenic road, xii, 22, 93

Piping, 35

Ponderosa pine-juniper, viii, 5, 39, 74

Ponds

$$
\begin{aligned}
& \text { brood, } 7,18,21,45,63, \\
& \quad 83,90,99
\end{aligned}
$$

stock, 39

Population (human), 27, 57,60

Predator control (see animal damage control)

Prescribed burns (see fire management)

Prescription grazing (see grazing)

Primitive camp sites, 22, 93

Private cabins, ix, $x, x i$, xii, $8,14,18,20,26,27$, $52,66,87$

Public law, i, 2, 32, 57

\section{$\underline{R}$}

Range condition, $\mathrm{x}, 12,21$, $24,41,62,65,67,71,74$ $85,89,90,91$

Range deterioration, ix, $62,64,65,67,82,85,89$, 92,98

Range developments, $\mathrm{x}, \mathrm{xi}$, $8,9,13,16,20,22,25,66$, $85,92,101$

boundary fences, $\mathrm{x}, \mathrm{xi}$, xii, 10, 13, 18, 20, 25, 71, 81,
$86,92,98$

interior fences, $x, x i, 13,20$, $71,86,92,97$

water development projects, $\mathrm{x}, \mathrm{xi}, 9,10,13,20,71,77,78$, 92,97

Range objectives, $5,66,75,85,91$ 94,99

Range survey, 41,65

Recreation activities, ix, 17,20, $27,33,52,55,61,77,86,87$

Recreation areas, ix, $8,11,13,16$, $17,20,22,23,25,26,27,37,50$, $66,67,77,78,86,87,100$

Recreation demand, $16,55,86,87$

Recreation objectives, 4,6,67,77

$86,94,101$

Refuge Administration Act, 1

Refuge Revenue Sharing Act of 1978,57

Research natural areas, ix, 14

Residual cover, ix, x, 39,63,71, 81

$82,84,90,92,98$

Rest-rotation grazing system

(see grazing systems)

Riparian zones, viii, 5,16,19,

$21,22,41,64,73,90,91,99,100$

Riverbottom (riparian), 11,19,39, $41,73,83$

Rorippa calycina, ix, 50

\section{$\underline{\mathrm{S}}$}

Sail/powerboat tour route, 14,78 Scenic tour route, 14,27

Scoping process, 1

Seaplane landings (see aircraft landing)

Seasonal grazing (see grazing)

Seasons of use, 9,10,42,66,76,92

Section 7 evaluations, 3

Security cover, 19,21,39,64,65

Short-term impacts, 61,71

Sport fishing access, 16

Slippery Ann area, 14,78

Socioeconomics, 27,55,57,78,87, 94,101

benefits, $26,57,68$

costs, 26,55

employment, 27,29,55-60,68, 
$79,87,95,103$

income, ix, 27, 29, 55-60, 68, $79,87,95,103$

Soils

limitations \&

capability, 12,36

(orders):

Aridisols, 36

Entisols, 36

Mollisols, 36

Vertisols, 36

Soil erosion, $13,20,37,62$

$70,81,89,97$

Stock ponds (see range

developments \& ponds)

Surveys

aerial, 7

ground, 7

habitat analysis pro-

cedures, 10

range (methodology), 41

\section{$\mathrm{T}$}

Taylor Grazing Act, 1

Threatened species, ix,4, 33,50

Trails

backcountry, xi,xii, 14,20, $22,78,87,93,94$

canoe, 14

nature, $\mathrm{xi}, 14,20,78,87$

Trapping, 9,52

Turn-in dates, 12, 13, 76

\section{U}

UL Bend National Wildlife Refuge, xi, $21,50,83,85,90,91$

Unauthorized use, 52,61

Unique species, $x, x i i, 7,10$, $18,21,44,77$

Upper Missouri National Wild

\& Scenic River, viii,4,8, $14,33,50,52$

\section{$\underline{\mathrm{V}}$}

Vegetative types, viii,3,39

Vertisols (see soils)
Visitor contact station (see interpretive facilities)

$\underline{W}$

Water development projects (see range developments)

Water resources, 36

Wilderness areas, ix, 3,4,20, $50,81,85$

Wildfires

(see fire management)

Wildlife habitat, i,17,20,39, $61,63,91$

Wildlife habitat analysis, 3, 24

Wildlife habitat management plan, 10,11,13

Wildlife indicator species, 3 (see indicator wildlife species)

Wildlife-livestock problems (see livestock-wildlife interrelationships)

Wildife objectives, 5,9,10, $16,26,74,83,85,93,99,100$

Wildlife-oriented recreation (see wildlife-related recreation)

Wildlife pastures, 8,14,42,50

Wildlife-related recreation, $x, x i$, $4,6,27,41,52,67,77,78,94,101$

Wildlife species

amphibians, 50

black-footed ferret, ix, x $3,5,7,10,18,21,24,50$, $65,71,77,90,98$

birds, 44, 45

buffalo, 18,82

bald eagle, ix, 5, 7,10,50

bighorn sheep, $\mathrm{x}, 5,7,10,18$, $21,24,31,44,63,71,90,98$

e1k, ix, 11, 16,19,24, 26,39, $42,44,57,64,71,73,74,91$, $92,98,100$

fishes, 45

peregrine falcon, $i x, x, 5,7$, $10,18,21,24,50,71,77,86$, $90,94,98,101$

prairie dogs, 3,5,10,44,71, 
72,81

pronghorns, $3,5,7$,

$11,26,31,44,64$

$71,72,73,76,82$,

$96,98,100$

mule deer, $3,5,7$,

$11,16,19,39,42$,

$64,71,72,73,76$,

$82,83,85,91,93$,

98,100

reptiles, 50

sage grouse, ix, 7 ,

$11,16,45,64,76$,

$82,85,92,98,100$

sharp-tailed grouse,

$3,5,7,16,31,39$,

$45,63,64,71,73,82$,

$83,85,90,93,98,100$

swift fox, $10,18,21$,

$24,77,98$

waterfow1, $5,7,16,45$,

$63,73,83,93,98$

white-tailed deer, 5,

$16,19,41,42,64,73$,

98

Wildlife tour route, 8,14 , 50,78

Wildlife winter range, 72 ,

76,99

$\underline{Y}$

Yearlong grazing

(see grazing) 

CHARLES M. RUSSELL

NATIONAL WILDLIFE REFUGE

ENVIRONMENTAL STATEMENT

\section{REFERENCE MAP}

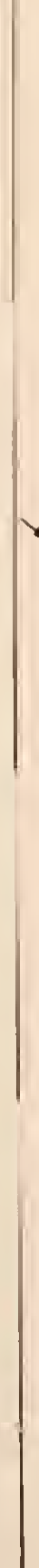

(1) FWs Headquarters

Coros of Engineors Headauarerers

Note fort Peck Recrenstion Areas Include

An force Psik

Bip Muddy

Downstream

Diedge Cuts

Fort Peek Wast

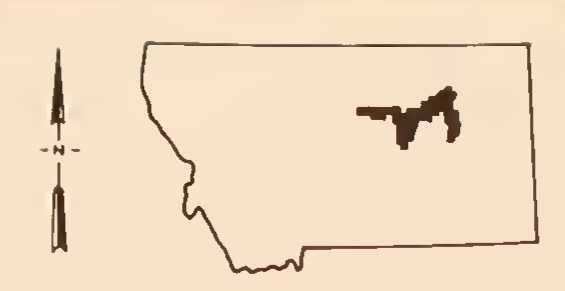

FIG. 10 REFERENCE MAP

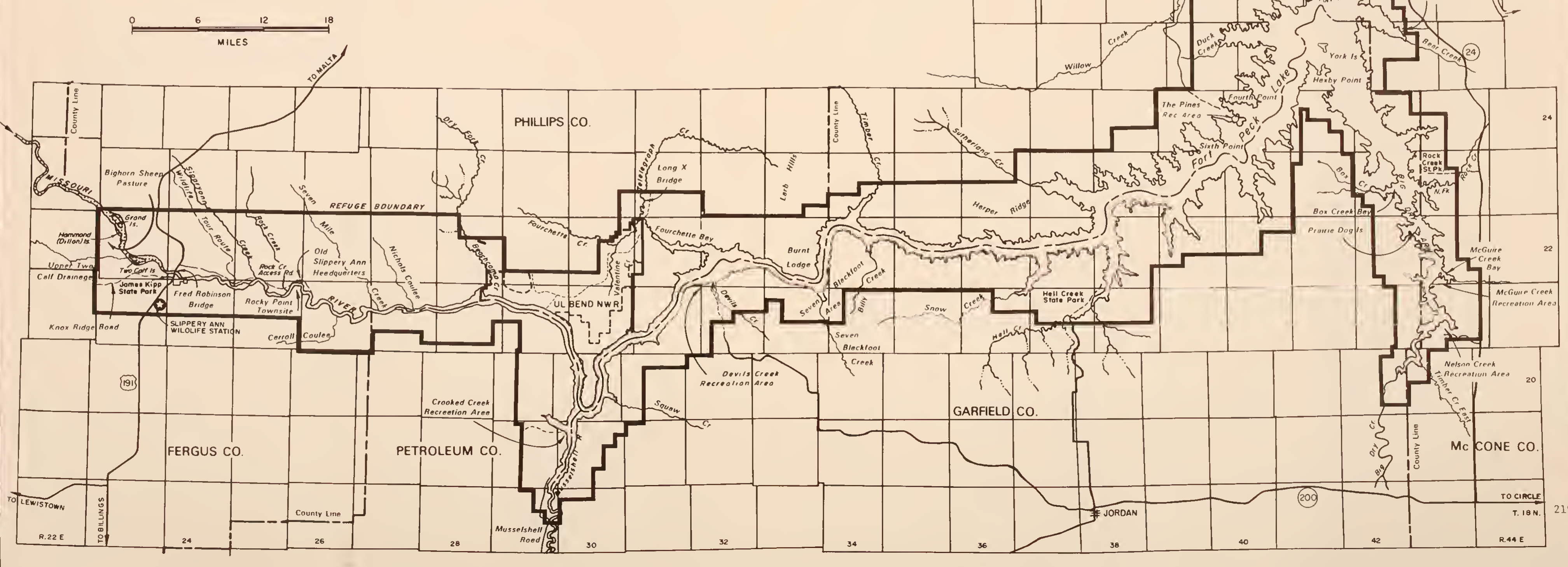





\section{F \\ Whar s anead}

능

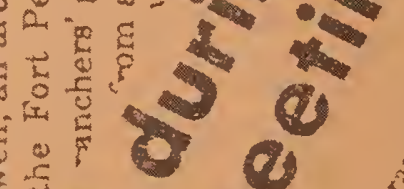

is

(1) o

$\geq 2$

$=$

$0 x^{2}$ 8

$\underline{0}=0^{\circ}$

व.

10i CWV graging

(1)

$\pm 4$

$\sum_{1}^{0} \stackrel{0}{0}$
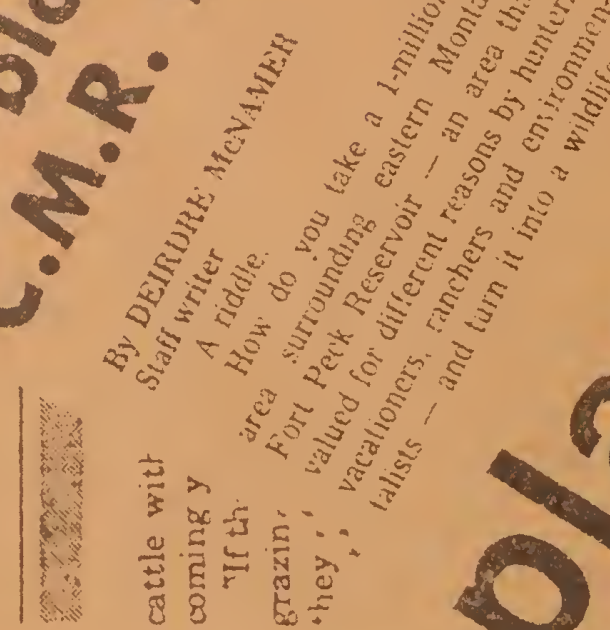

er grazing

IR r $\mathrm{B}_{\mathrm{Ob} \mathrm{c}^{2}}$

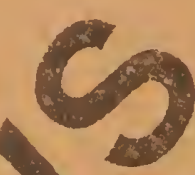

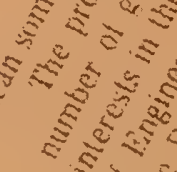

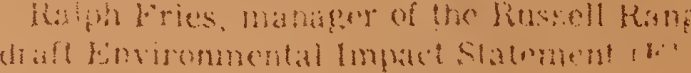

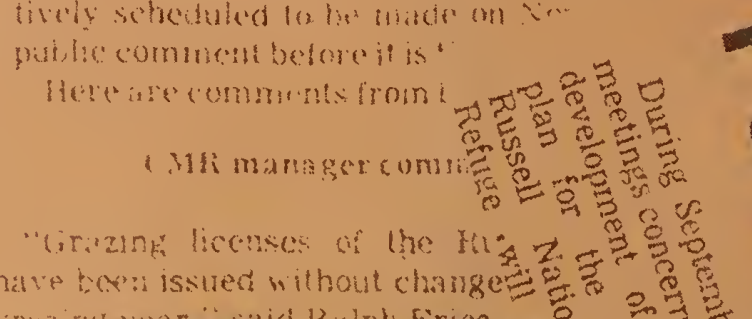

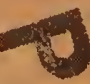

2

r

$v$

$c$

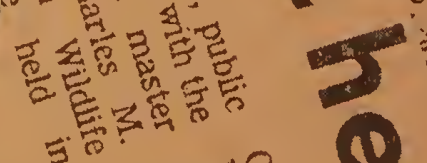
$\div$

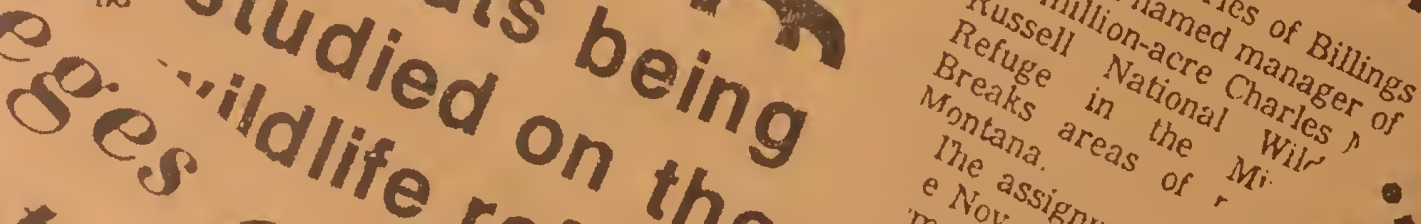
$=0$ arefth

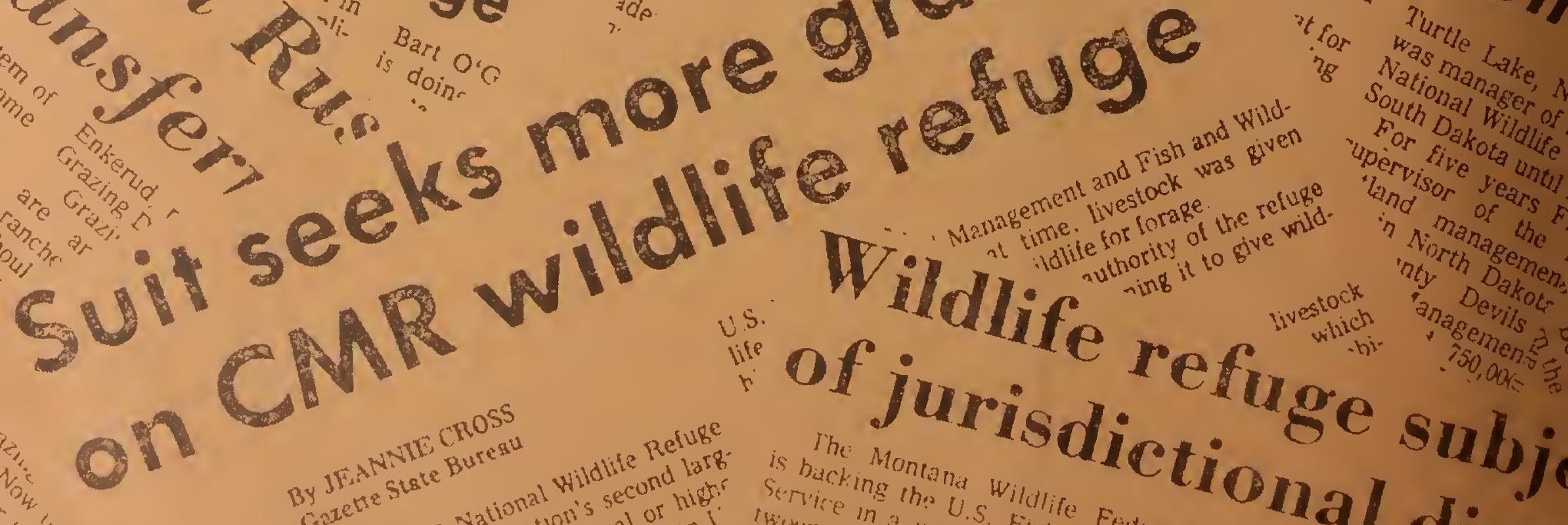
(a) 